UNIVERSIDADE DE SÃO PAULO

INSTITUTO DE GEOCIÊNCIAS

\title{
APLICAÇÃO DE TÉCNICAS QUÍMICAS DE REMEDIAÇÃO EM ÁREAS CONTAMINADAS POR COMPOSTOS ORGANOCLORADOS
}

\author{
Alaine Santos da Cunha \\ Orientador: Reginaldo Antônio Bertolo
}

DISSERTAÇÃO DE MESTRADO

Programa de Pós-Graduação em Geologia Sedimentar e Ambiental

São Paulo

2010 
Ficha catalográfica preparada pelo Serviço de Biblioteca e Documentação do Instituto de Geociências da Universidade de São Paulo

Cunha, Alaine Santos da

Aplicação de técnicas químicas de remediação em áreas contaminadas por compostos organoclorados / Alaine Santos da Cunha. - São Paulo, 2010. 101 p. : il. + anexos.

Dissertação (Mestrado) : IGc/USP

Orient.: Bertolo, Reginaldo Antônio

1. Poluição de águas subterrâneas 2. Águas subterrâneas: Remediação 3. Hidrogeologia 4. Compostos voláteis I. Título 
meus amores:

minha família,

Cláudio Lemos,

Ziggy e Mel. 


\section{AGRADECIMENTOS}

Agradeço a todos que de alguma forma contribuíram para o bom andamento deste trabalho, ou simplesmente demonstraram interesse em alguma etapa do projeto, mas em especial:

Ao meu orientador Reginaldo Bertolo pela paciência e disponibilidade em me ajudar a apresentar da melhor forma possível o conteúdo do meu trabalho e em entender as dificuldades enfrentadas por mim na condução das atividades necessárias para a conclusão desta dissertação de mestrado.

Ao Instituto de Geociências da Universidade de São Paulo que possibilitou o desenvolvimento deste trabalho.

Ao Paulo César Casado, sempre prestativo, que muito me ajudou na obtenção de dados no início do projeto.

À ERM que disponibilizou todos os dados utilizados e permitiu que a conclusão de mais esse estágio da minha carreira profissional.

Aos amigos e colegas de trabalho pelas dicas, trocas de experiência e convivência agradável que muito me ajudaram.

À minha família, em especial aos meus pais, pelo apoio e presença em toda a minha vida e ao meu querido Cláudio Lemos pela paciência e conforto em momentos difíceis. 


\section{RESUMO}

\section{CUNHA, A. S. Aplicação de Técnicas Químicas de Remediação em Áreas} Contaminadas por Compostos Organoclorados. 2010. 129 fls. Dissertação (Mestrado) Instituto de Geociências - Universidade de São Paulo, São Paulo.

Grande parte das áreas contaminadas conhecidas atualmente advém de práticas passadas onde os cuidados com a proteção à saúde humana e ao meio ambiente eram desconhecidos ou ignorados. O uso indiscriminado de produtos solventes clorados fez com que tais compostos se tornassem uma das principais fontes de contaminação no setor industrial. Por serem compostos de alta toxicidade, quando presentes na água subterrânea, mesmo em baixas concentrações, a tornam imprópria para o consumo.

Técnicas de remediação como atenuação natural, ou que envolvam bombeamento e tratamento de água subterrânea contaminada por solventes clorados, vêm sendo substituídas por metodologias químicas destrutivas, por apresentarem resultados satisfatórios em um período de tempo inferior às técnicas utilizadas anteriormente.

Este trabalho objetiva apresentar os resultados obtidos em duas áreas industriais onde foram aplicadas técnicas de remediação, envolvendo a redução química in situ, através da injeção de polisulfeto de cálcio e a oxidação química in situ, com a injeção de permanganato de potássio. Em ambas as áreas, os contaminantes organoclorados são os principais compostos de interesse presentes na água subterrânea.

A redução química in situ é uma metodologia que utiliza um agente químico para reduzir óxidos de ferro III, presentes naturalmente no aquífero sedimentar, e transformá-los em ferro II que, por sua vez reduzirá contaminantes organoclorados. A principal característica desta metodologia é a eliminação contígua de dois átomos de cloro das moléculas dos contaminantes, o que tende e diminuir ou eliminar o acúmulo de subprodutos tóxicos como cloreto de vinila.

$\mathrm{Na}$ oxidação química in situ, o agente promove a transferência de elétrons, onde os íons $\mathrm{Cl}^{-}$das moléculas dos contaminantes são substituídos por $\mathrm{H}^{+}$. Devido à baixa reatividade entre o permanganato de potássio e a matriz do aquífero durante as reações de oxidação química, este oxidante pode ser transportado pelos processos advectivo e dispersivo juntamente com o fluxo da água subterrânea e persistir por um período maior de tempo, reagindo com os contaminantes orgânicos.

Ensaios de bancada com solo saturado contaminado de uma das áreas de estudo mostraram excelentes resultados na utilização do polisulfeto de cálcio, mas o mesmo não foi observado no teste piloto realizado em campo. Embora tenha sido observada dispersão do produto nas proximidades de pelo menos um dos pontos onde a solução foi injetada, notou- 
se que não houve redução significativa dos contaminantes, evidenciando que o ferro II não foi eficaz no processo de degradação. Isto pode ter sido ocasionado por uma série fatores, como possíveis reações, características hidráulicas, ou geológicas do meio. Portanto, o prosseguimento desta metodologia como alternativa de remediação para toda a área impactada foi descontinuado, tornando necessário novos estudos para avaliar a melhor técnica aplicável na área.

Quanto à área onde foi aplicada a oxidação química, a remediação foi considerada eficiente. Ao longo do período de vinte e dois meses, quando foram realizadas atividades de monitoramento da água subterrânea, observou-se a presença do permanganato de potássio nas áreas mais impactadas das plumas de contaminação, fato que permitiu o processo de transferência de elétrons e consequentemente a oxidação dos contaminantes. Vinte e dois meses após as atividades de injeção, o principal contaminante identificado na área, o 1,-1-dicloroeteno, foi detectado em apenas um ponto com concentração superior a meta de remediação obtida anteriormente à injeção. Considerando que durante a sequência das atividades relacionadas à remediação, este contaminante sofreu alterações em seus valores toxicológicos estabelecidos pela Agência de Proteção Ambiental dos Estados Unidos, e passou a ser considerado um composto não carcinogênico, todos os poços apresentaramse com concentrações inferiores a nova meta de remediação calculada.

Como efeito colateral, foi observado o aumento das concentrações de metais dissolvidos, como: alumínio, bário, cromo e ferro. Tal mobilização de metais para a água subterrânea pode ser considerada temporária. Após o total consumo do permanganato de potássio pelos contaminantes ainda presentes no meio, as características físico-químicas do aquífero retornarão à situação identificada naturalmente, permitindo a precipitação dos metais.

Palavras-chave: Contaminação. Composto organoclorado. Remediação. Redução química in situ. Oxidação química in situ. 


\section{ABSTRACT}

\section{CUNHA, A. S. Aplicação de Técnicas Químicas de Remediação em Áreas} Contaminadas por Compostos Organoclorados. 2010. 129 fls. Dissertação (Mestrado) Instituto de Geociências - Universidade de São Paulo, São Paulo.

Most of the currently known contaminated areas are the result of past practices, where precautions regarding protection of human health and the environment were either unknown or ignored. The indiscriminate use of chlorinated solvents is the driving factor that has led to such compounds becoming one of the main sources of contamination in the industrial sector. Chlorinated solvents are highly toxic and, when present at even low concentrations in groundwater, they make this resource unfit for human consumption.

Such remediation techniques as natural attenuation, or that involve pumping and treatment of groundwater contaminated by chlorinated solvents, are currently being replaced by destructive chemical methods, as they show satisfactory results in a shorter period of time than previously used techniques.

This study has the objective of showing the results obtained at two industrial sites where remediation techniques have been used involving in-situ chemical reduction, through injection of calcium polysulfide, and in-situ chemical oxidation, with injection of potassium permanganate. At both sites, organochlorine contaminants are the main compounds of concern present in groundwater.

In-situ chemical reduction is a methodology that uses a chemical agent in order to reduce iron III oxides, naturally present in the sedimentary aquifer, and transform them into iron II which, in turn, reduces the organochlorine contaminants. The principal characteristic of this methodology is that of contiguous elimination of two chlorine atoms from contaminant molecules, which tends to reduce or eliminate accumulation of such toxic byproducts as vinyl chloride.

In in-situ chemical oxidation, the chemical agent brings about a transfer of electrons, where the $\mathrm{Cl}^{-}$ions of contaminant molecules are replaced by $\mathrm{H}^{+}$ions. Due to the low degree of reactivity between potassium permanganate and the aquifer matrix during chemical oxidation reactions, this oxidizing agent can be transported via groundwater flow, by advective and dispersive processes, and persist for a longer period of time, reacting with organic contaminants.

Bench tests performed with contaminated saturated soil from one of the sites under study showed excellent results through the use of calcium polysulfide; however, the same results were not observed during a pilot test performed in the field. Although product dispersion was observed in the vicinity of at least one of the points where the solution had 
been injected, it was found that there was no significant reduction of contaminants, showing that iron II was not effective in enhancing the degradation process. This could have been the result of a series of factors, for example, possible reactions or the hydraulic or geological characteristics of the medium. Therefore, it was decided not to continue with use of this methodology as a remediation alternative for the whole impacted area, making it necessary for further studies in order to assess the best technique applicable at the site.

With respect to the site where a chemical oxidation approach was adopted, remediation was considered to be effective. Over a period of twenty-two months, during which groundwater monitoring activities were performed, the presence of potassium permanganate was observed in the most impacted areas of the contamination plumes, a fact that allowed for the electron transfer process and, consequently, contaminant oxidation. Twenty-two months after initiation of injection activities, the main contaminant identified at the site (1,1-dichloroethene) was only detected at one point at a concentration exceeding the post-remediation target value established prior to commencing these activities. Considering that, during the sequence of activities related to the remediation process, this contaminant underwent changes in its toxicological values established by the United States Environmental Protection Agency, and came to be considered a non-carcinogenic compound, all wells showed concentrations below the new calculated post-remediation target.

As a collateral effect, there was found to be an increase in concentrations of such dissolved metals as aluminum, barium, chromium and iron. Such mobilization of metals to groundwater can be considered a temporary effect. Following complete consumption of potassium permanganate by contaminants still present in the medium, the physical-chemical characteristics of the aquifer will return to the situation occurring naturally, allowing for the precipitation of these metals.

Keywords: Contamination. Organochlorine Compounds. Remediation. In situ chemical reduction. In situ chemical oxidation. 


\section{INDICE}

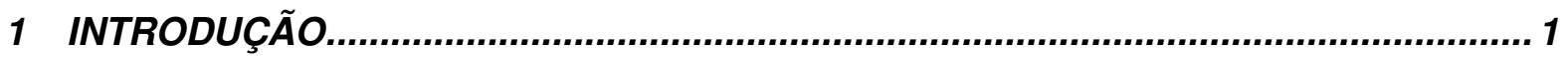

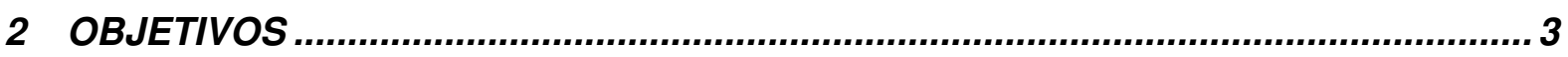

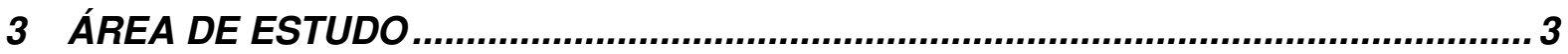

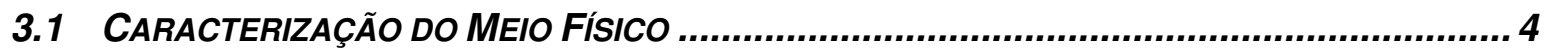

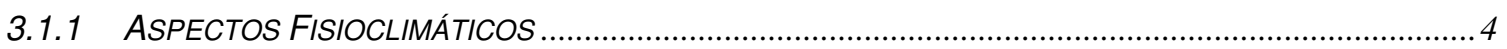

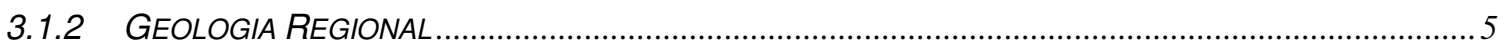

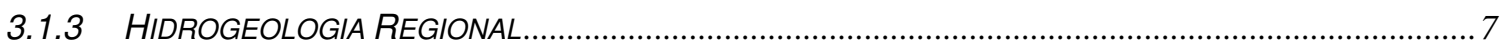

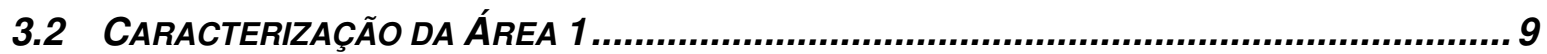

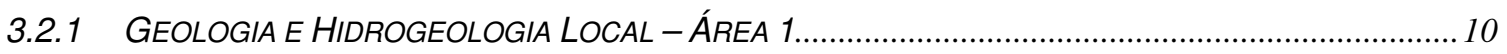

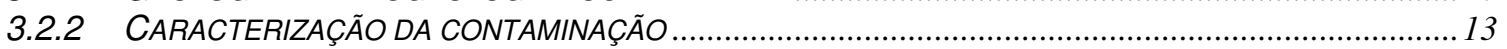

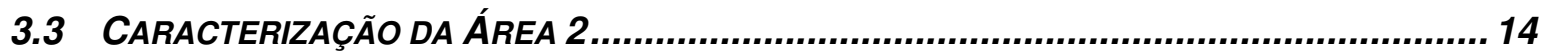

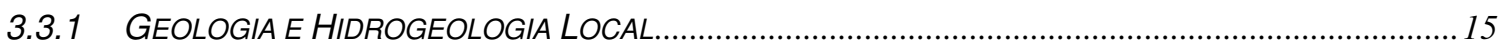

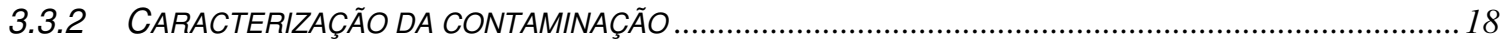

3.4 Avaliação Preliminar de Potencials TÉcnicas de Remediação.......................... 19

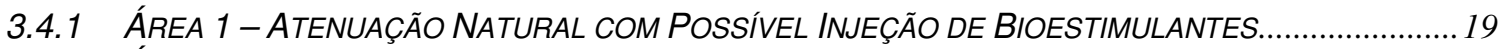

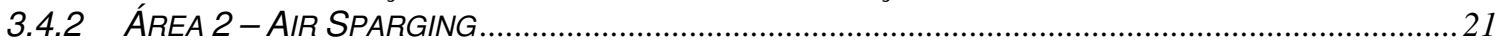



4.1 Propriedades Químicas e Comportamento Geoquímico dos Contaminantes ... 21

4.2 Metodologias de Degradação de Contaminantes OrgÂNICOS......................... 26

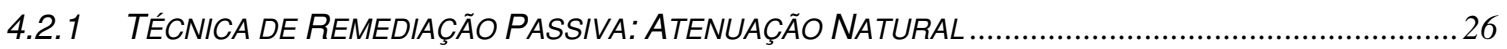

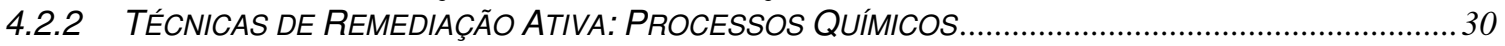

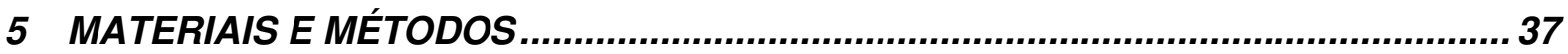

5.1 APLICAÇÃO dA TÉCNICA dE REDUÇÃO QUÍMICA IN SITU ........................................ 38

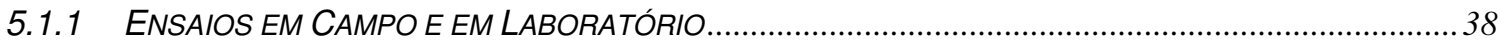

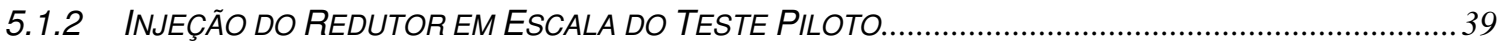

5.2 APLICAÇÃO DA TÉCNICA DE OXIDAÇÃO QUÍMICA IN SITU........................................ 45

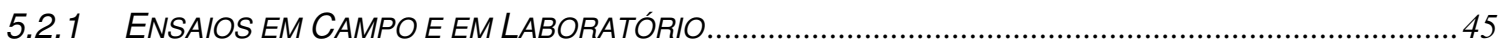

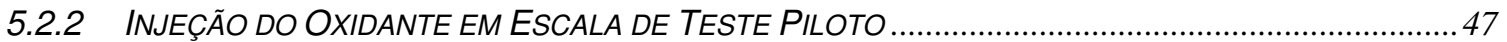



6 APRESENTAÇÃO E INTERPRETAÇÃO DOS RESULTADOS DO TESTE PILOTO

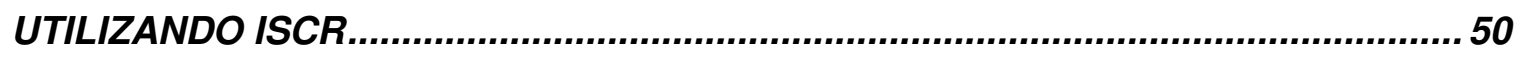

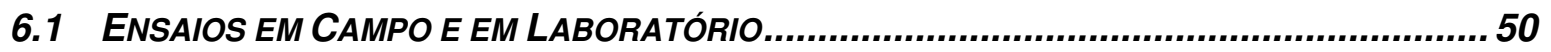

6.2 INJEÇÃo do REDUTOR EM ESCALA DE TESTE PILOTO.............................................. 55

6.2.1 SUMÁRIO DOS DADOS DE PARÂMETROS FÍSICO-QUÍMICOS.......................................................... 56 


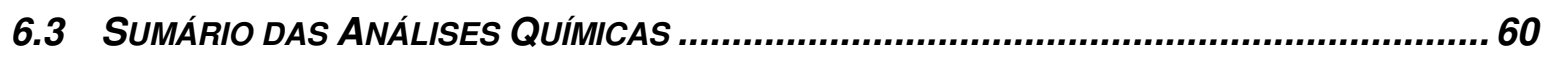

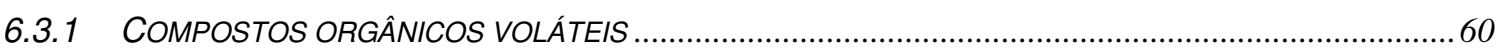

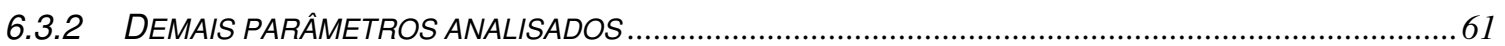

6.4 INTERPRETAÇÃo dos RESUltadOS DO TESTE PILOTO UTILIZANDO ISCR ................... 63

7 APLICAÇÃO DA OXIDAÇÃO QUÍMICA IN SITU COM PERMANGANATO DE POTÁSSIO PARA REMEDIAÇÃo DE ÁREA CONTAMINADA POR SOLVENTES

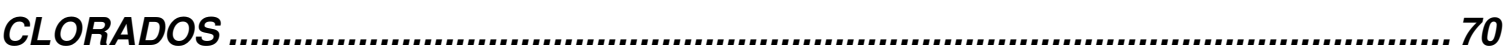

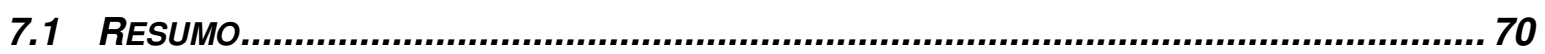

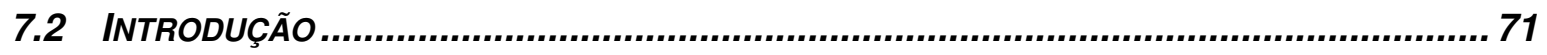

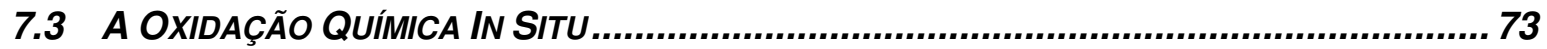

7.4 ÁREA DE ESTUDO

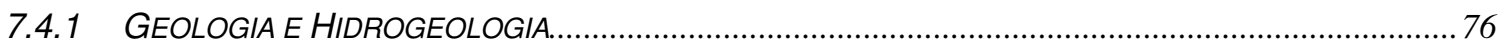

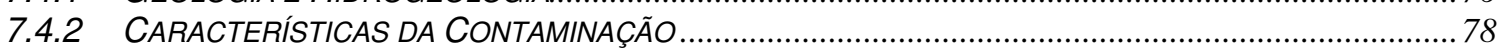

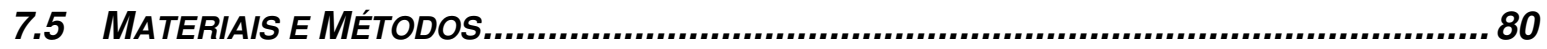

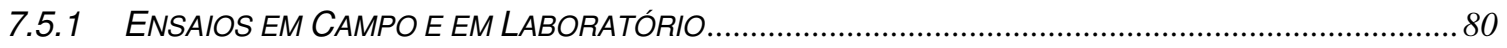

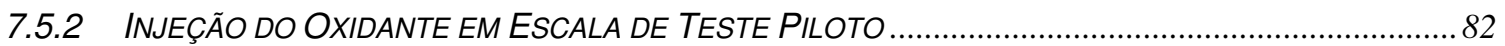

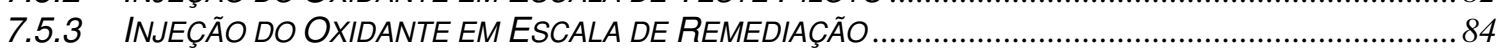

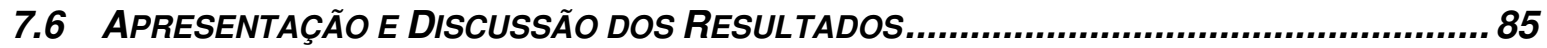

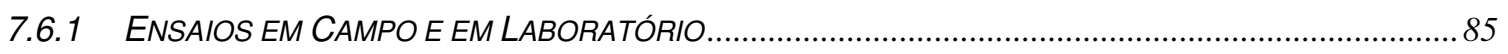

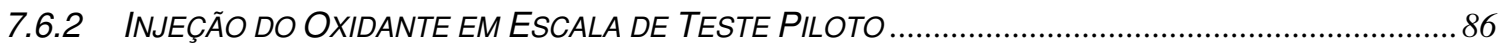

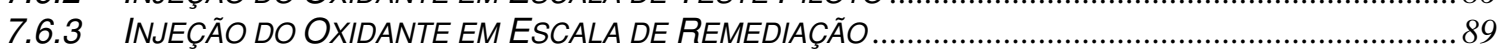

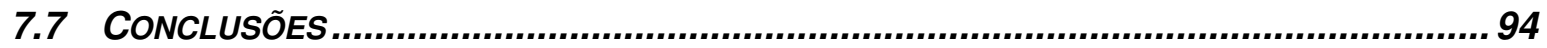

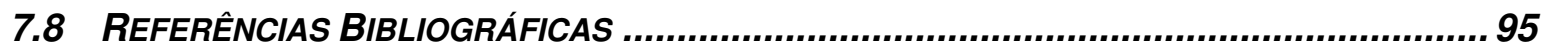

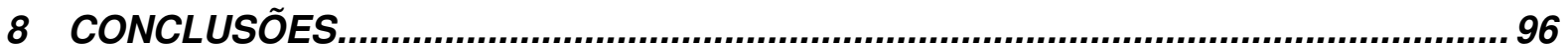

8.1 INJEÇÃo do REDUTOR EM ESCALA DE TESTE PILOTO............................................... 96

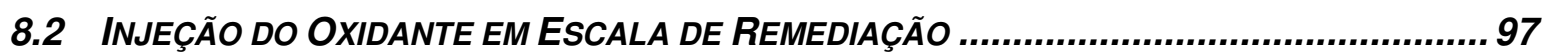

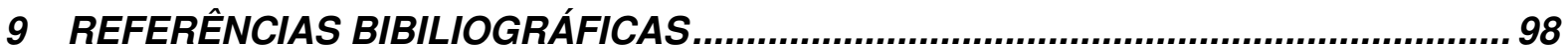

ANEXO 1 PERFIS CONSTRUTIVOS

ANEXO 2 ANÁLISES QUÍMICAS 


\section{LISTA DE FIGURAS}

Figura 1 - Mapa de localização da área de estudo (Fonte: Mapa Rodoviário do Estado de São Paulo - DER, 2009) .........................................................................

Figura 2 - Mapa geológico da área de estudo (Fonte: IPT, 1981) .......................................5

Figura 3 - Limite do Aquífero Tubarão na Bacia hidrográfica do rio Piracicaba (Fonte: Ferraz e Mortatti, 2003). .8

Figura 4 - Identificação das áreas potencialmente contaminadas (Área 1).........................10

Figura 5 - Diagrama representativo da estratigrafia da Área 1 ........................................12

Figura 6 - Identificação das áreas potencialmente contaminadas (Área 2).........................15

Figura 7 - Diagrama representativo da estratigrafia da Área 2 .......................................16

Figura 8 - Apresentação da direção preferencial do fluxo da água subterrânea do aquífero

freático e a configuração da pluma de contaminação de 1,1-DCE antes da injeção do oxidante em toda a área (situação em março de 2008).

Figura 9 - Processos de partição do contaminante no solo, ar e água em subsuperfície.

(Fonte: Modificado de USEPA, 2004).... .24

Figura 10 - Estados de oxidação de vários alcanos e alcenos clorados e $\mathrm{CO}_{2}$. (Fonte:

Modificado de Suthersan e Payne, 2005). 25

Figura 11 - Principais compostos e possíveis sequências de degradação. (Fonte: Modificado

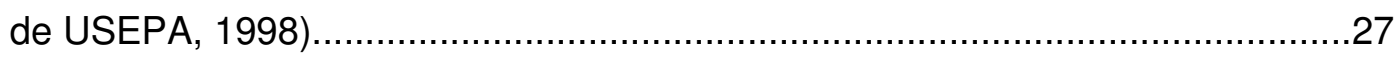

Figura 12 - Potenciais caminhos de degradação dos cloroetenos......................................31

Figura 13 - Detalhe da área do teste piloto de ISCR ........................................................40

Figura 14 - Perfil esquemático de um poço de injeção..........................................................46

Figura 15 - Resultados dos ensaios de microcosmos para 1,1-DCE.................................54

Figura 16 - Resultados dos ensaios de microcosmos para 1,1-DCA ...................................55

Figura 17 - Comparação dos parâmetros analisados ao longo dos monitoramentos (Conj.

RW-02).

Figura 18 - Comparação dos parâmetros analisados ao longo dos monitoramentos (Conj. RW-04). 66

Figura 19 - Principais compostos obtidos ao longo dos monitoramentos (Conj. RW-02)......67

Figura 20 - Comparação das concentrações de ferro dissolvido e sulfato ao longo dos monitoramentos .69

Figura 21 - Diagrama representativo da estratigrafia da área. .77

Figura 22 - Apresentação da direção preferencial do fluxo da água subterrânea do aquífero freático e a configuração da pluma de contaminação de 1,1-DCE antes da injeção do oxidante em toda a área (situação em março de 2008). 
Figura 23 - Perfil construtivo esquemático de um poço de injeção. .81

Figura 24 - Presença de $\mathrm{KMnO}_{4}$ nos poços de monitoramento durante e após o período de injeção do teste piloto. 88

Figura 25 - Apresentação da área tratada no teste piloto e raios de influência inicialmente previstos de $6 \mathrm{~m}$ (situação em maio de 2005).

Figura 26 - Localização dos poços de injeção previstos para a remediação da área até concentrações inferiores à meta de remediação.

Figura 27 - Presença de $\mathrm{KMnO}_{4}$ nos poços de monitoramento durante e após o período de injeção em toda a área.

Figura 28 - Comparação entre os resultados de monitoramento de desempenho da ação do $\mathrm{KMnO}_{4}$ em seis e vinte e dois meses após as atividades de injeção em toda a área. .92

Figura 29 - Comportamento da concentração de 1,1-DCE ao longo das campanhas de monitoramento de desempenho do $\mathrm{KMnO}_{4}$ em alguns poços de monitoramento selecionados. 


\section{LISTA DE TABELAS}

Tabela 1 - Descrição das Áreas Potencialmente contaminadas da Área 1............................

Tabela 2 - Descrição das Áreas Potencialmente contaminadas da Área 2..........................15

Tabela 3 - Propriedades básicas dos compostos de interesse...........................................22

Tabela 4 - Exemplo de concentrações de metais identificadas em amostra de permanganato de potássio considerada não ideal para remediação de área

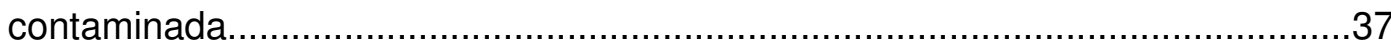

Tabela 5 - Plano de amostragem da caracterização inicial..................................................42

Tabela 6 - Plano de amostragem do processo de mistura................................................43

Tabela 7 - Plano de amostragem do monitoramento inicial................................................44

Tabela 8 - Plano de amostragem do monitoramento de desempenho................................45

Tabela 9 - Avaliação dos resultados do teste de injeção de água (poços de injeção RW-01 e RW-02)

Tabela 10 - Avaliação dos resultados do teste de injeção de água (poços de injeção RW-03

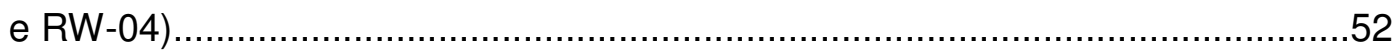

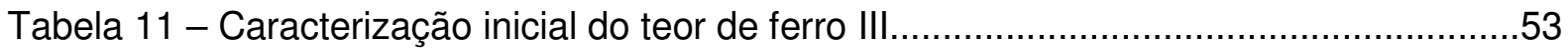

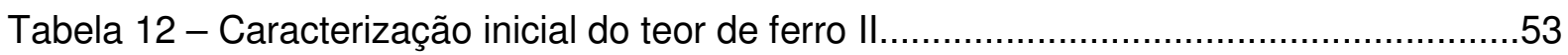

Tabela 13 - Resultados da avaliação eliminatória de potenciais agentes redutores............54

Tabela 14 - Parâmetros físico-químicos nos tanques de injeção..........................................56

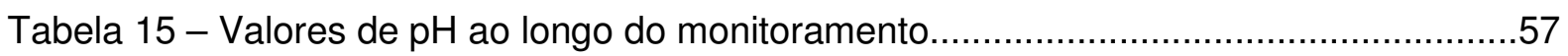

Tabela 16 - Valores de potencial de oxi-redução ao longo do monitoramento.......................58

Tabela 17 - Valores de condutividade elétrica ao longo do monitoramento...........................59

Tabela 18 - Concentrações de VOCs totais ao longo do monitoramento.............................60

Tabela 19 - Valores de ferro bivalente dissolvido e sulfato ao longo do monitoramento.......62

Tabela 20 - Valores de alcalinidade e RedEq ao longo do monitoramento.........................63

Tabela 21 - Proporção molar de ferro bivalente dissolvido e 1,1-DCA comparado à VOCs totais.

Tabela 22 - Exemplo de concentrações de metais identificadas em amostra de permanganato de potássio que pode ser considerada não ideal para remediação de área contaminada.

Tabela 23 - Avaliação dos resultados do teste de injeção de água.

Tabela 24 - Resultados analíticos utilizados para aplicação da ISCO.

Tabela 25 - Informações necessárias para o cálculo do dimensionamento do sistema de remediação considerando o centro de massa de uma das plumas de 1,1-DCE a ser tratada no teste piloto e para a remediação de toda a área. 
Tabela 26 - Concentrações médias de metais dissolvidos identificados na água subterrânea.

Tabela 27 - Concentrações máximas de metais dissolvidos identificados na água subterrânea..... 


\section{LISTA DE SIGLAS E ABREVIAÇÕES}

$\begin{array}{ll}\text { AP } & \text { Área Potencialmente Contaminada } \\ \text { CETESB } & \text { Companhia Ambiental do Estado de São Paulo } \\ \text { CF } & \text { Clorofórmio } \\ \text { CT } & \text { Carbon Tetrachloride (Tetrachloromethane) } \\ \text { DCA } & \text { Dicloroetano } \\ \text { DCE } & \text { Dicloroeteno } \\ \text { DCM } & \text { Diclorometano } \\ \text { DER } & \text { Departamento de Estradas e Rodagem } \\ \text { DNAPL } & \text { Dense Non-Aqueous Phase Liquid } \\ \text { DOC } & \text { Dissolved Organic Carbon } \\ \text { DOE } & \text { Departament of Energy } \\ \text { DQO } & \text { Demanda Química de Oxigênio } \\ \text { IPT } & \text { Instituto de Pesquisas Tecnológicas } \\ \text { ISCO } & \text { In Situ Chemical Oxidation } \\ \text { ISCR } & \text { In Situ Chemical Reduction } \\ \text { NOD } & \text { Natural Oxidant Demand } \\ \text { ORP } & \text { Oxidation Reduction Potential } \\ \text { PCE } & \text { Tetracloroeteno } \\ \text { PEAD } & \text { Polietileno de Alta Densidade } \\ \text { PVC } & \text { Poly Vinyl Chloride } \\ \text { RedEq } & \text { Redutor Equivalente } \\ \text { SOD } & \text { Soil Oxidant Demand } \\ \text { TCA } & \text { Tricloroetano } \\ \text { TCE } & \text { Tricloroeteno } \\ \text { TOC } & \text { Total Organic Carbon } \\ \text { USEPA } & \text { United States Environmental Protection Agency } \\ \text { VC } & \text { Vinyl Chloride } \\ \text { VOC } & \text { Volatile Organic Compound } \\ \text { ZVI } & \text { Zero Valent Iron } \\ \end{array}$




\section{INTRODUÇÃO}

Grande parte das áreas contaminadas conhecidas atualmente advém de práticas passadas onde os cuidados com a proteção à saúde humana e ao meio ambiente eram desconhecidos ou simplesmente desrespeitados. A Companhia Ambiental do Estado de São Paulo (CETESB), em maio de 2002, divulgou pela primeira vez que havia 255 registros de áreas contaminadas no Estado de São Paulo. Em sua última atualização, realizada em maio de 2009, esse número aumentou para 2.904, segundo o Cadastro de Áreas Contaminadas e Reabilitadas no Estado de São Paulo (CETESB, 2009).

O uso indiscriminado de produtos solventes clorados no passado fez com que tais compostos se tornassem uma das principais fontes de contaminação no setor industrial.

Pelo que se tem conhecimento, os solventes clorados foram primeiramente produzidos na Alemanha no século XIX. A produção nos Estados Unidos foi iniciada por volta de 1906. Mas foi com o crescimento do período industrial na Segunda Guerra Mundial, que estes produtos, com alto poder desengraxante, passaram a ser difundidos e seu uso se tornou mais intenso pelas três décadas seguintes. O conhecimento da contaminação do solo e da água subterrânea por parte destes produtos só passou a ser conhecida a partir do final da década de 1970 (Pankow e Cherry, 1996).

Os solventes clorados são utilizados comercialmente como produto puro, mas normalmente são identificados na água na sua forma dissolvida, em concentrações que vão de $\mu \mathrm{g} / \mathrm{L}$ (ppb) a mg/L (ppm). A presença destes contaminantes na água subterrânea, mesmo que em baixas concentrações, fazem com que esta se torne imprópria para consumo, trazendo potencial risco à saúde humana e ao meio ambiente (Pankow e Cherry, 1996).

$O$ conceito de que os recursos naturais são finitos e, portanto, devem ser preservados, é primordial para que a contaminação seja prevenida ou que áreas anteriormente contaminadas possam ser reabilitadas a partir da implantação de sistemas eficientes de remediação, mas a constante supervisão por parte de órgãos ambientais é de grande importância para que atividades potencialmente poluidoras sejam identificadas e sanadas.

Sob características geoquímicas específicas, a contaminação presente em subsuperfície pode ser naturalmente degradada a partir do processo de atenuação natural, (incluindo biodegração, dispersão, adsorção e volatilização). Apesar disso, esta metodologia soma desvantagens como: 1) longo tempo para alcançar o objetivo da remediação; 2) alto custo e complexidade na caracterização da área; 3) possibilidade de toxicidade mais elevada dos produtos de formação em comparação aos produtos originais; e 4) migração contínua dos contaminantes até que sejam degradados (USEPA, 1998). 
Como a atenuação natural pode se tornar inviável como alternativa para a reabilitação de uma área contaminada, técnicas de remediação destrutivas de massa de contaminante in situ, como oxidação, redução e outros processos biogeoquímicos vêm sendo utilizadas de forma mais intensa, devido à eficiência e custo mais atrativos. A ação destes processos promove zonas reativas que podem interceptar, imobilizar ou degradar contaminantes até produtos filhos não perigosos (Suthersan e Payne, 2005). Assim, processos de degradação de natureza química abiótica, geralmente tendem a ser mais viáveis e mais adequados para a reabilitação de uma área impactada, de forma que potenciais riscos possam ser anulados ou gerenciados de maneira mais eficiente.

Duas das metodologias químicas destrutivas de contaminantes clorados que são abordadas e apresentadas no desenvolver deste trabalho são: redução química in situ (In Situ Chemical Reduction - ISCR) e oxidação química in situ (In Situ Chemical Oxidation ISCO). Estas alternativas de remediação foram selecionadas para tratamento de duas áreas distintas e próximas entre si, impactadas por contaminantes organoclorados, onde o contexto geológico se refere ao manto de intemperismo desenvolvido sobre rochas sedimentares do membro inferior da Formação Tatuí (Aquífero Tubarão, Bacia do Paraná).

Embora ambas as áreas apresentem similaridades quanto aos contaminantes que deram origem à contaminação, bem como o contexto geológico em que estão inseridas, apresentam disparidades quanto aos compostos filhos presentes na água subterrânea. $A$ presença dos contaminantes no solo não foi identificada em nenhuma das áreas estudadas. Em virtude disto, diferentes técnicas de remediação foram selecionadas para aplicação.

Para que um processo de remediação seja realizado da forma adequada, são necessárias diversas etapas de trabalho, que envolvem: 1) avaliação preliminar para identificar áreas potencialmente contaminadas e quais os possíveis contaminantes; 2) investigações ambientais confirmatórias e detalhadas, para identificar e delimitar a área impactada; 3) ensaios conduzidos em campo e laboratório para avaliar as características físico-químicas específicas da área; 4) testes piloto para verificar se a alternativa de remediação pretendida é a mais adequada; e 5) a remediação propriamente dita, envolvendo toda a área de interesse.

Em virtude das diferentes características em que as áreas de estudo estão envolvidas, ambas se encontram em fases distintas do projeto de remediação. Na primeira, são apresentadas as atividades realizadas até o desenvolvimento do teste piloto para uma possível implantação da técnica de redução química in situ em toda a área impactada, enquanto na segunda, todas as etapas citadas anteriormente foram realizadas e a oxidação química in situ foi aplicada em toda a área, como alternativa para reabilitação do meio.

Esta dissertação encontra-se estruturada e redigida de forma convencional. Entretanto, para clareza do leitor, explica-se que o capítulo 7 deste trabalho foi redigido em 
forma de artigo a ser futuramente submetido a uma revista científica e descreve as atividades realizadas para embasar a aplicação da ISCO em toda a área impactada de uma das áreas de estudo.

\section{OBJETIVOS}

Este trabalho objetiva apresentar a sequência das atividades realizadas e os resultados da aplicação de duas técnicas químicas de remediação in situ, a redução química e a oxidação química, em plumas de contaminação de compostos organoclorados situadas em uma mesma área industrial e num mesmo contexto hidrogeológico.

Em ambas as situações, procurou-se avaliar: 1) se houve contato dos agentes oxidante ou redutor com os contaminantes em todo o aquífero afetado pelas plumas de contaminação; 2) se as massas dos agentes oxidante e redutor foram suficientes para destruir os contaminantes até a meta de remediação; e 3) se algum efeito geoquímico colateral indesejável foi identificado no aquífero com a injeção dos agentes.

\section{3 ÁREA DE ESTUDO}

O local onde foram desenvolvidas as atividades apresentadas neste estudo está situado numa área industrial na cidade de Limeira, interior do Estado de São Paulo (Figura 1).

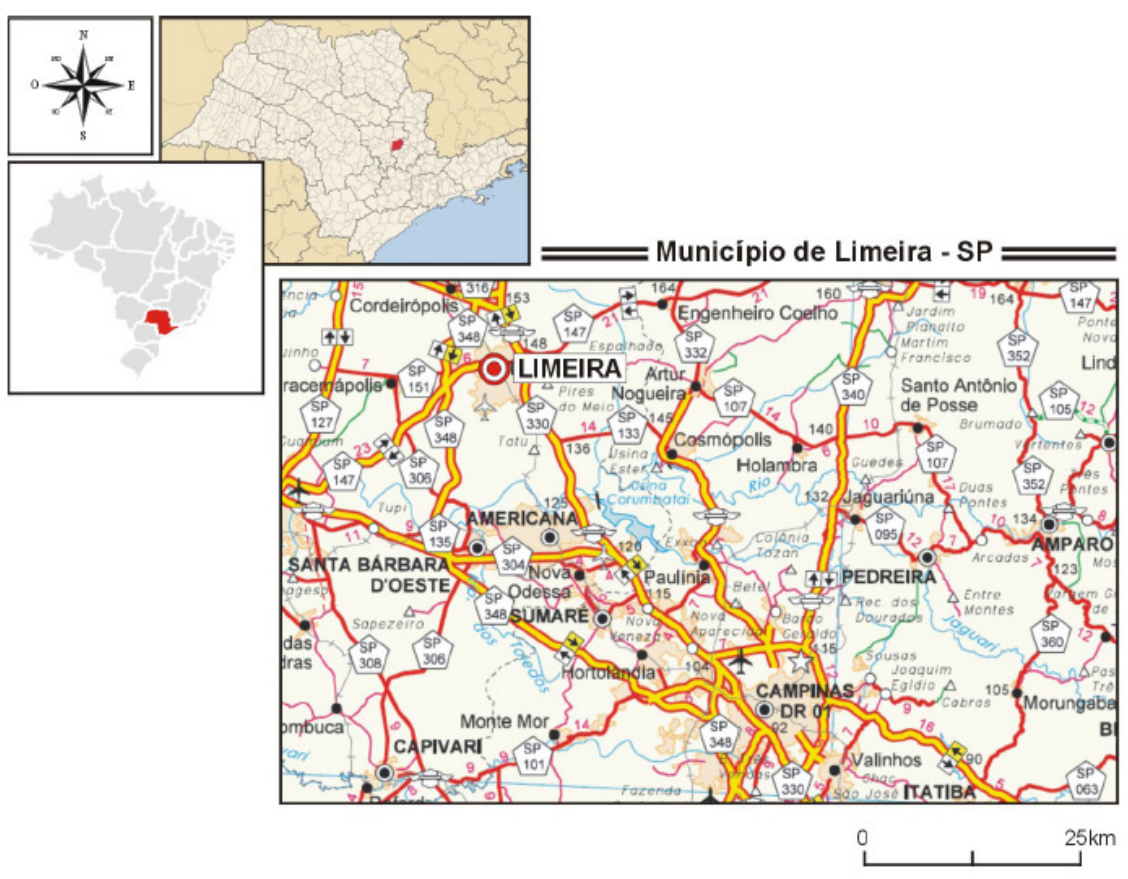

Figura 1 - Mapa de localização da área de estudo (Fonte: Mapa Rodoviário do Estado de São Paulo - DER, 2009) 


\subsection{Caracterização do MeIo Físıco}

\subsubsection{ASPECTOS FISIOCLIMÁTICOS}

\section{Relevo}

O município de Limeira situa-se no domínio da depressão periférica, faixa de aproximadamente $50 \mathrm{~km}$ de largura e direção SW-NE, localizada entre as cuestas basálticas e as rochas pré-cambrianas do Planalto Atlântico. De acordo com o Mapa Geomorfológico do Estado de São Paulo (IPT, 1981), a região de Limeira apresenta as seguintes unidades de relevo:

- Relevo colinoso: com predomínio de baixas declividades (0 a $15 \%$ ) e amplitudes locais inferiores a $100 \mathrm{~m}$. Fazem parte desse relevo colinas amplas onde predominam interflúvios com área superior a $4 \mathrm{~km}^{2}$, topos extensos e aplainados, vertentes com perfis retilíneos a convexos, redes de drenagem de baixa densidade e planícies aluviais interiores restritas; e

- Relevo de morrotes: com predomínio de declividades médias a altas (superiores a $15 \%$ ) e amplitudes locais inferiores a $100 \mathrm{~m}$. Fazem parte desse relevo, morrotes alongados e espigões com presença de interflúvios sem orientação preferencial, topos angulosos, vertentes ravinadas com perfis retilíneos, rede de drenagem de média a alta densidade e vales fechados.

\section{Clima}

De acordo com a classificação de W. Köppen, o clima da região pode ser quente de inverno seco (Cwa), apresentando temperaturas médias acima de $22{ }^{\circ} \mathrm{C}$, no mês mais quente, e abaixo de $18{ }^{\circ} \mathrm{C}$ no mês mais frio. Nos meses mais secos, os índices médios de chuva podem ficar abaixo de $30 \mathrm{~mm}$ (Rocha; Fernandes, 2005).

\section{Solos}

De modo geral a região de Limeira faz parte da área onde são encontrados os grupos de Latossolos Vermelhos, configurados por solos minerais, não hidromórficos com horizontes $B$ latossólicos (Oliveira et. al., 1999). Os altos teores de óxidos de ferro $\left(\mathrm{Fe}_{2} \mathrm{O}_{3}\right)$ conferem a esses solos cores avermelhadas. Entre esse grupo de solos, o município de Limeira apresenta duas unidades principais. Faz parte da sua maior porção, mais a leste, o solo do tipo Latossolo Vermelho-Escuro Distrófico, com horizonte A moderado, textura muito argilosa e relevo suave ondulado (LEd1). Já numa proporção menor, na região extremo oeste do município é encontrado o solo do tipo Latossolo Vermelho-Escuro + Latossolo Roxo eutrófico, com horizonte A moderado, textura argilosa a muito argilosa de relevo suave ondulado (LEd7). 


\section{Hidrografia}

O município de Limeira fica na porção centro-leste do Estado de São Paulo, e pertence à bacia hidrográfica do rio Piracicaba. A bacia do rio Piracicaba apresenta um desnível topográfico de cerca de $1.400 \mathrm{~m}$ em uma extensão da ordem de $370 \mathrm{~km}$, desde suas cabeceiras na serra da Mantiqueira, no Estado de Minas Gerais, até sua foz no Rio Tietê.

Os principais cursos d'água pertencentes a esta bacia hidrográfica são os rios Atibaia, Jaguari, Corumbataí, Piracicaba e Camanducaia.

\subsubsection{GEOLOGIA REGIONAL}

Localizada no município de Limeira no Estado de São Paulo, a área de estudo situa-se na borda leste da Bacia do Paraná. Esta bacia intracratônica apresenta formação ligada à subsidência na plataforma Sul-Americana a partir do Siluriano/Devoniano inferior, atingindo extensão máxima entre o Carbonífero Superior e o Permiano. Fazem parte das unidades próximas à área de estudo as formações Corumbataí, Iratí, Tatuí e Grupo Itararé (Figura 2). Também estão presentes depósitos aluviais quaternários, coberturas cenozóicas indiferenciadas e rochas intrusivas básicas da Formação Serra Geral.

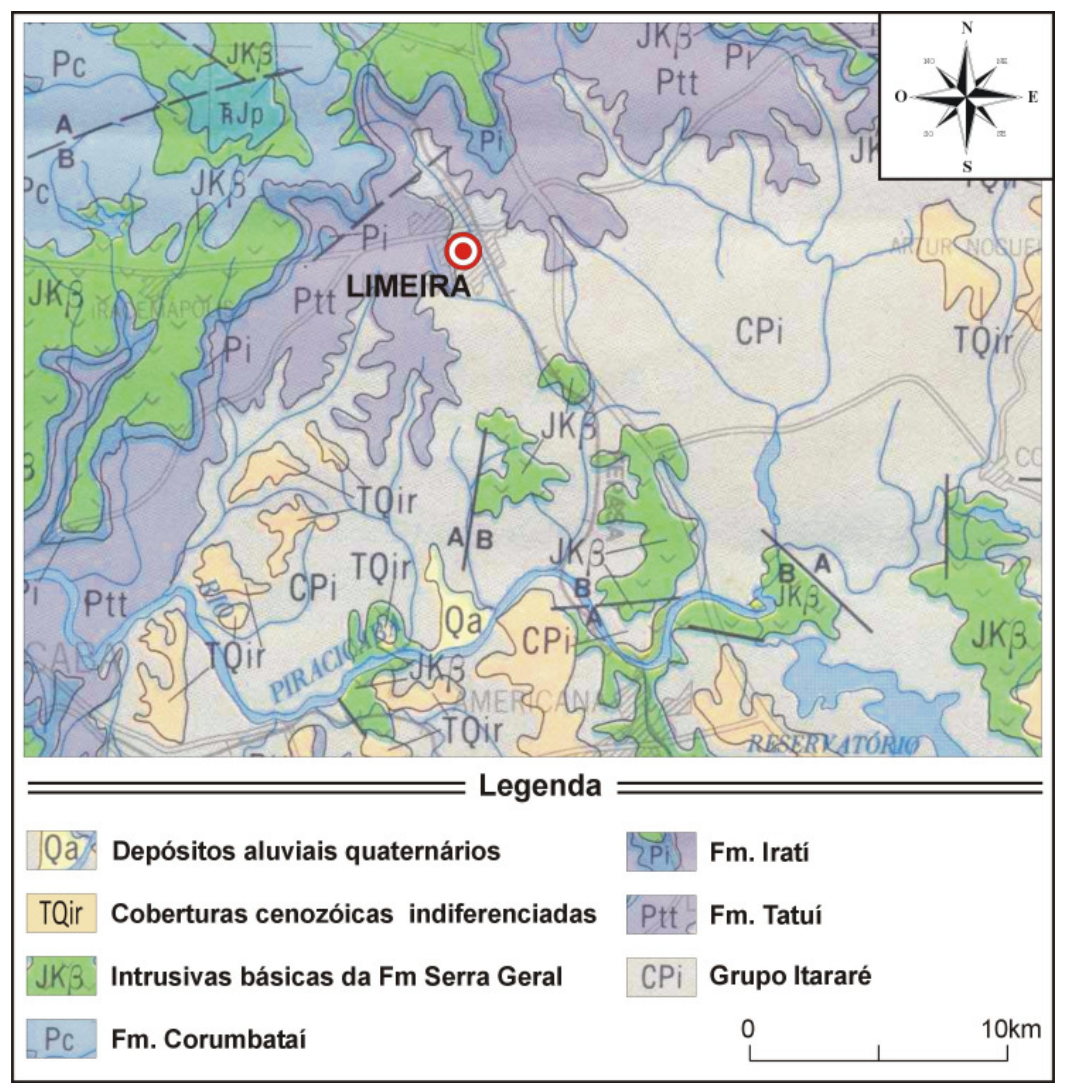

Figura 2 - Mapa geológico da área de estudo (Fonte: IPT, 1981) 
A Formação Corumbataí no Estado de São Paulo apresenta espessura geralmente inferior a $150 \mathrm{~m}$ e aflora continuamente do divisor de águas dos rios Tietê e Piracicaba para norte, até próximo ao limite com Minas Gerais, quando não interrompida por sills de diabásio ou falhas (IPT, 1981).

A Formação Corumbataí em sua parte inferior apresenta siltitos, argilitos e folhelhos cinzentos a roxo acinzentado nos afloramentos. Segue-se uma sucessão de camadas siltosas, ritmicamente alternadas com lâminas ou delgadas camadas cuja litologia varia entre argilosa e arenosa fina, tanto vertical quanto horizontalmente (Mendes, 1952b; Almeida; Barbosa, 1953; Barbosa; Gomes, 1958; Landim, 1970 apud IPT, 1981).

Observam-se estruturas sedimentares como estratificação plano-paralela, cruzada de baixo ângulo, estruturas flaser, estratificação rítmica, marcas onduladas, fraturas de ressecamento e brechas intraformacionais. A Formação Corumbataí jaz em concordância sobre a Irati, mas seu contato com a Formação Pirambóia é por discordância erosiva. Ao desaparecer a Formação Irati na zona norte da Depressão Periférica, a Formação Corumbataí passa a repousar em discordância erosiva sobre o Grupo Tubarão. A separação é dada por uma zona conglomerática, rica em seixos de sílex com 1,30 m de espessura (Landim, 1970 apud IPT, 1981).

Sobre o ambiente de deposição da Formação Corumbataí, Schneider (et al., 1974, apud IPT, 1981) consideram a parte inferior da formação como tendo sido depositada em ambiente marinho de águas gradativamente mais rasas, em condições climáticas redutoras. A porção superior resultaria da deposição em águas rasas, em condições climáticas oxidantes, sob influência de marés, com freqüentes avanços progradacionais de sedimentação litorânea.

A Formação Irati constitui-se de folhelhos pirobetuminosos, folhelhos pretos não betuminosos, dolomitos cinzentos e alternados com folhelhos escuros, calcários dolomitizados, siltitos, folhelhos e arenitos finos, cinzentos. Ocasionalmente na base da formação ocorrem arenitos de granulação fina a grossa, conglomerática e camadas de conglomerado (IPT, 1981).

Em 1958, Barbosa e Gomes dividiram a Formação Irati nos Membros Taquaral e Assistência, a passagem entre ambos e gradual.

O Membro Taquaral é de natureza pelítica, constituído por argilitos, folhelhos de cor cinza clara a escura e siltitos. Na base pode ocorrer, em São Paulo, camada delgada de arenito de granulação fina a grossa, seixoso, ou conglomerado com seixos de sílex e quartzo (Washburne, 1930; Almeira; Barbosa, 1953; Mezzalira, 1957; Barbosa; Gomes, 1958; Andrade; Soares, 1971, apud IPT, 1981). A espessura máxima do Membro Taquaral não excede $20 \mathrm{~m}$ e em São Paulo, raramente se apresenta com mais de $10 \mathrm{~m}$, embora de forma generalizada na Bacia do Paraná (Shneider et al., 1974, apud IPT, 1981). 
O Membro Assistência apresenta litologia bem mais variada, destacando-se a presença de dolomitos e calcários parcialmente dolomitizados e de folhelhos pirobetuminosos e piritosos (Amaral, 1971). Nos leitos de dolomito e calcário podem-se observar marcas de ondas, estruturas convolutas, oólitos, laminação algática, brecha intraformacional local e dobramentos devidos a deslizamentos (IPT, 1991).

Quanto ao ambiente de deposição, há indícios tanto de marinho de águas rasas, em bacia ou bacias grandemente confinadas, em clima adequado à precipitação de calcários e condições físico-químicas favoráveis à sua dolomitização e à acumulação de matéria orgânica geradora dos pirobetumes (Schneider et al., 1974, apud IPT, 1981), quanto de lagoas marginais em lenta subsidência com estreita ligação com o mar, numa região de relevo baixo Amaral (op cit., apud, IPT, 1981).

A Formação Tatuí é predominantemente constituída de siltitos. Subordinadamente ocorrem camadas de arenitos, calcários, folhelhos e sílex. No conjunto apresenta sedimentação muito uniforme, que contrasta com a heterogeneidade característica da Formação Itararé. Sua maior espessura em superfície é de cerca de $130 \mathrm{~m}$, no sul do Estado de São Paulo, valor que diminui para nordeste e norte, em direção à borda da bacia sedimentar (IPT, 1981). Na porção aflorante, esta formação apresenta espessuras médias entre 30 e 50 m, podendo ultrapassar 70 m (DAEE, IG, IPT e CPRM, 2005).

$\mathrm{Na}$ base, a formação apresenta relações de discordância erosiva com as Formações Itararé e Aquidauana, podendo localmente possuir conglomerado basal ou ainda brusca mudança litológica. O contato superior com o Membro Taquaral, também apresenta caráter erosivo, embora em certos locais parece haver continuidade entre ambos (IPT, 1981). Localmente, o pacote superior inicia-se com lentes de arenitos de granulação média a grossa, imaturos, micáceos, com estratificação cruzada, podendo exibir marcas de onda. Associam-se a arenitos finos com estratificação plano-paralela, em que se alternam as cores verde e arroxeada (IPT, 1981).

A idade da formação, considerando sua posição na coluna estratigráfica, seria aproximadamente a do limite Kunguriano/Kazaniano. Seu ambiente de sedimentação seria o de bacia aquosa de baixa energia, possivelmente marinha (Almeida e Barbosa, op cit., IPT, 1981).

\subsubsection{HidRogeologia REgIONAL}

Dentro da bacia do rio Piracicaba, o município de Limeira se encontra no contexto do Aquífero Tubarão (Figura 3).

A faixa aflorante do Aquífero Tubarão localiza-se no centro-sudeste do Estado de São Paulo, ocupando uma área de $20.700 \mathrm{~km}^{2}$ (450 x $45 \mathrm{~km}$ ). Insere-se na Depressão Periférica Paulista, envolvendo parte das Unidades de Gerenciamento de Recursos Hídricos 
(URGHI) 4 (Pardo), 5 (Piracicaba/Capivari/Jundiaí), 9 (Mogi-Guaçu), 10 (Tietê/Sorocaba) e 14 (Alto Paranapanema) (DAEE, IG, IPT e CPRM, 2005).

Como áreas de descarga do Aquífero Tubarão encontram-se os rios Piracicaba e Capivari (Pereira e Silva, 1997).

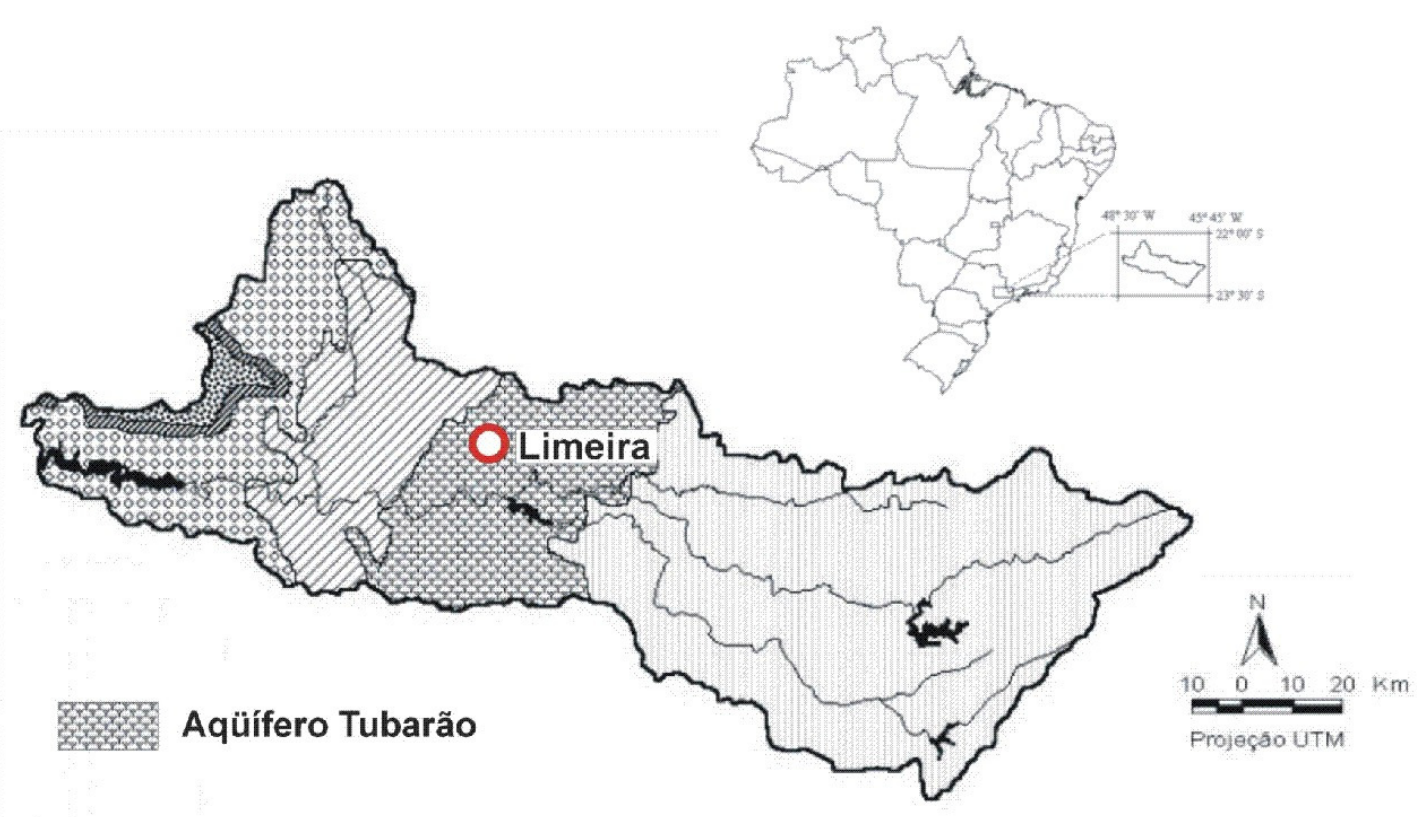

Figura 3 - Limite do Aquífero Tubarão na bacia hidrográfica do rio Piracicaba (Fonte: Ferraz e Mortatti, 2003)

Este aquífero apresenta aumento de espessura no sentido oeste, a partir do seu limite leste na linha de contato com o embasamento pré-cambriano. As principais unidades geológicas do Aquífero Tubarão são: (1) Grupo Itararé e Aquidauana (Permo-Carbonífero), depositados em ambiente glacial continental com ingressões marinhas; e (2) Grupo Guatá (Permiano), que contém as formações Tatuí (predominante), Rio Bonito e Palermo (subordinadas), depositados em ambiente marinho raso. Dentre essas unidades, a Formação Tatuí ocorre na área de estudo. A Formação Tatuí se encontra estratigraficamente acima do Grupo Itararé, limitada por discordância erosiva, e abaixo da Formação Iratí. Próximo deste limite superior, com a Formação Iratí, a Formação Tatuí pode apresentar arenito conglomerático, ou conglomerado com seixos de sílex (Rocha e Fernandes, 2005).

O armazenamento e a circulação de água no Aquífero Tubarão ocorrem principalmente através dos interstícios dos sedimentos clásticos grosseiros (arenitos, conglomerados e diamictitos), intercalados com camadas de sedimentos finos (lamitos, argilitos e folhelhos), os quais dificultam a circulação vertical na infiltração e percolação da 
água, provocando uma situação de anisotropia com permeabilidade vertical inferior à horizontal. A interdigitação das camadas de granulometrias diferentes acentua a heterogeneidade do aquífero. No aquífero das rochas sedimentares finas (folhelhos, siltitos, argilitos e arenitos finos), a presença de sistemas de fraturamento atua como um diferencial na capacidade de acumulação e circulação de água (Barbosa; Almeida, 1949, apud IPT,1981).

\subsection{CARACTERIZAÇÃo dA ÁREA 1}

A primeira área de estudo (Área 1) ocupa $162.995 \mathrm{~m}^{2}$ dos quais $72.213 \mathrm{~m}^{2}$ compreendem prédios administrativos e de produção de peças automotivas. As atividades industriais nesta área foram iniciadas em 1962. Segundo informações obtidas, o uso de solventes clorados nas operações de desengraxe de peças e equipamentos foi mantido até 1993.

Com base na identificação das operações industriais realizadas nesta área, foi possível um mapeamento das Áreas Potencialmente Contaminadas (AP), direcionando, desta forma, as atividades de investigação, como apresentado na Tabela 1.

Tabela 1 - Descrição das áreas potencialmente contaminadas da Área 1

\begin{tabular}{cc}
\hline Área & Descrição \\
\hline AP-1 & Antigo posto de gasolina e antigo tanque enterrado \\
AP-2 & Antigo desengraxante a vapor \\
AP-3 & Antiga área de armazenamento de lodo \\
AP-4 & Antiga unidade de armazenamento de metal revestido e destilação de \\
AP-5 & solvente \\
AP-6 & Antigo tanque enterrado de óleo diesel \\
AP-7 & Antiga área de fundição \\
AP-8 & Banho de zinco - ALA IV \\
AP-9 & Banho de zinco - ALA I \\
\hline
\end{tabular}

Embora nesta área sejam encontradas APs relacionadas à outras possíveis fontes de contaminação, como a manipulação de metais, salienta-se que este trabalho apresenta apenas dados relacionados à contaminação de solventes organoclorados identificada na 
AP-4, local onde foi focada a aplicação da ISCR como teste piloto da metodologia de remediação. A Figura 4 apresenta a localização de todas as áreas potencialmente contaminadas observadas na área.

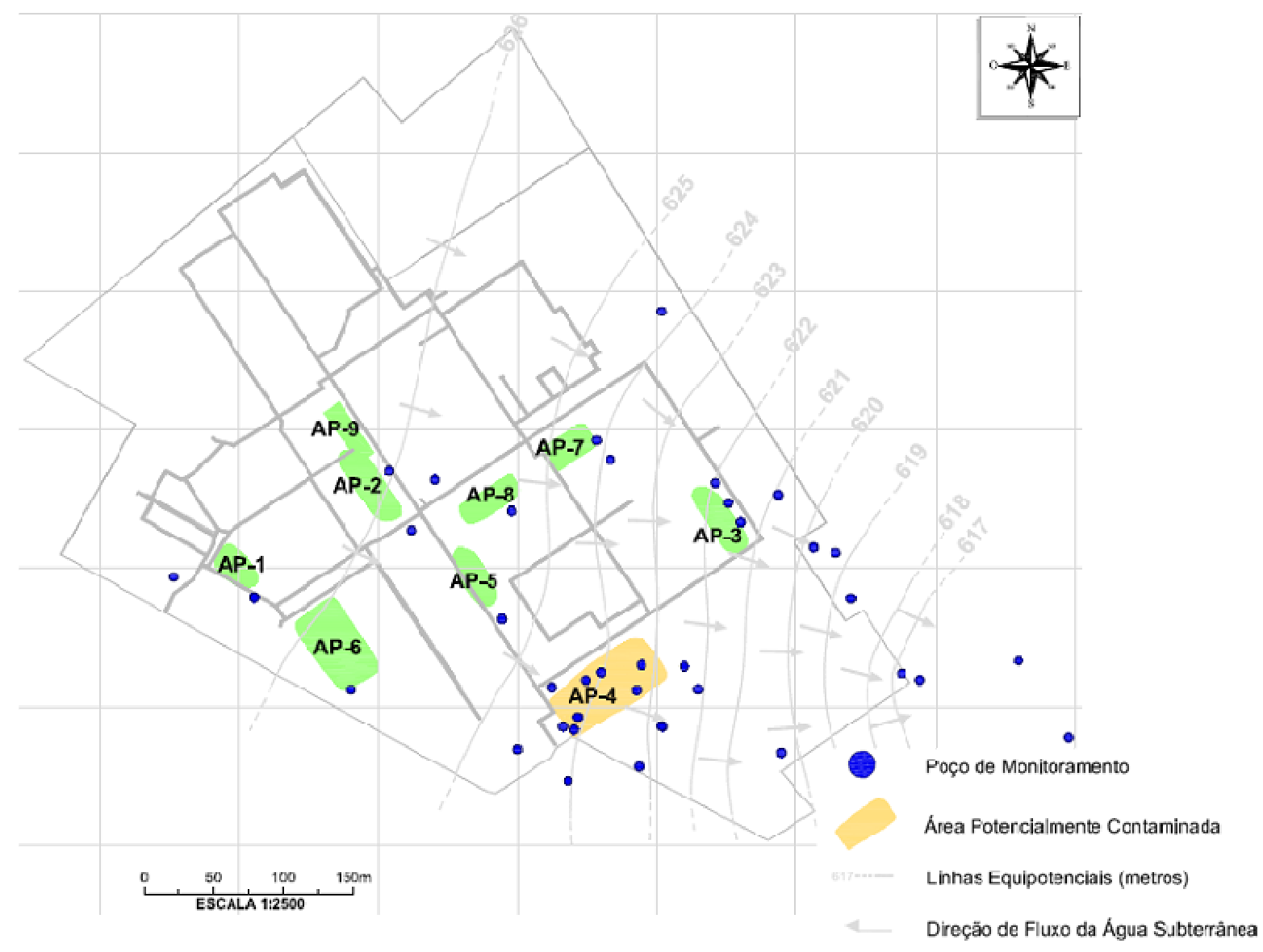

Figura 4 - Identificação das áreas potencialmente contaminadas (Área 1)

\subsubsection{Geologia E Hidrogeologia LoCAL - ÁreA 1}

A descrição geológica local foi obtida a partir de informações levantadas durante as atividades de perfuração do solo para instalação de poços de monitoramento. Foi possível observar a sobreposição em subsuperfície, do topo para a base, da seguinte descrição estratigráfica:

- Aterro: Predomínio de argila silto-arenosa, observa-se localmente entulho e raízes, apresenta coloração marrom a vermelho. Este material foi observado na porção sudeste da planta;

- Manto de intemperismo: Areia fina siltosa pouco argilosa, de baixa plasticidade e umidade, apresenta cor marrom avermelhada. Sua espessura possui variações ao longo da área podendo atingir intervalos entre 4 e $8 \mathrm{~m}$. De modo geral a diminuição da espessura se dá de noroeste para sudeste dentro da área; 
- Manto de intemperismo: Areia fina argilosa com presença de silte na matriz, com baixa plasticidade, cor amarela a avermelha. A variação de espessura está inferida entre $4 \mathrm{e}$ 12 m aproximadamente, com observação de descontinuidades na camada;

- Manto de intemperismo: Silte argiloso, com presença de areia fina, estruturas de laminação, alta plasticidade, com coloração branca, roxa, vermelha, e cinza amarelada. As características do material indicam correlação com as litologias referentes ao membro inferior da Formação Tatuí, reconhecida por Barbosa e Gomes (1958, apud IPT, 1981) e Soares (1972b, apud IPT, 1981);

- Rocha sã muito alterada: Silte arenoso (areia fina), compacto, com presença local de planos de fraturamento (preenchidos) com inclinação acentuada. Apresenta coloração predominantemente amarelada, porém com ocorrência de porções de cor roxa. Apesar de apresentar características pouco diferentes do material sobrejacente, também pode ser inferida correlação com a Formação Tatuí; e

- Rocha sã: Arenito fino, compacto, coloração cinza esbranquiçado a amarelado. Também foi observada entre as unidades da Formação Tatuí a presença local de arenitos finos (IPT, 1981).

A Figura 5 apresenta a estratigrafia da geologia identificada na área em forma de diagrama, a partir das atividades de perfuração do solo para a instalação de poços de monitoramento.

De modo geral, a Área 1 localiza-se numa área de recarga mais elevada quando comparada às áreas adjacentes. A topografia apresenta menores altitudes à medida que se avança no terreno no sentido leste, onde localmente alguns corpos d'água atuam como zonas de descarga locais da água subterrânea do aquífero freático.

Há uma variação de cerca de $25 \mathrm{~m}$ de altitude de um ponto dentro da planta em relação ao corpo d'água mais próximo, cerca de $500 \mathrm{~m}$ a leste. Este corpo d'água apresenta orientação aproximada NW-SE e aparenta ser a principal área de descarga em relação à área de estudo.

Os dados de cargas hidráulicas obtidos ao longo das atividades realizadas na área indicaram fluxo da água subterrânea no sentido preferencial para leste em direção à zona de descarga mais próxima.

Os testes hidráulicos realizados em quatro poços instalados na área do teste piloto conferiram uma condutividade hidráulica média de $1,99 \times 10^{-4} \mathrm{~cm} / \mathrm{s}$. Porém deve-se levar em consideração a heterogeneidade e anisotropia do meio, uma vez que a intercalação de lentes argilosas nas unidades é comum na área. Essa heterogeneidade e anisotropia devem conferir ao meio uma condutividade hidráulica vertical menor em relação à condutividade horizontal. 
Com a identificação do valor da condutividade hidráulica na área do teste piloto, foi obtida a velocidade média horizontal de fluxo advectivo da água subterrânea de $16 \mathrm{~m} / \mathrm{ano}$.
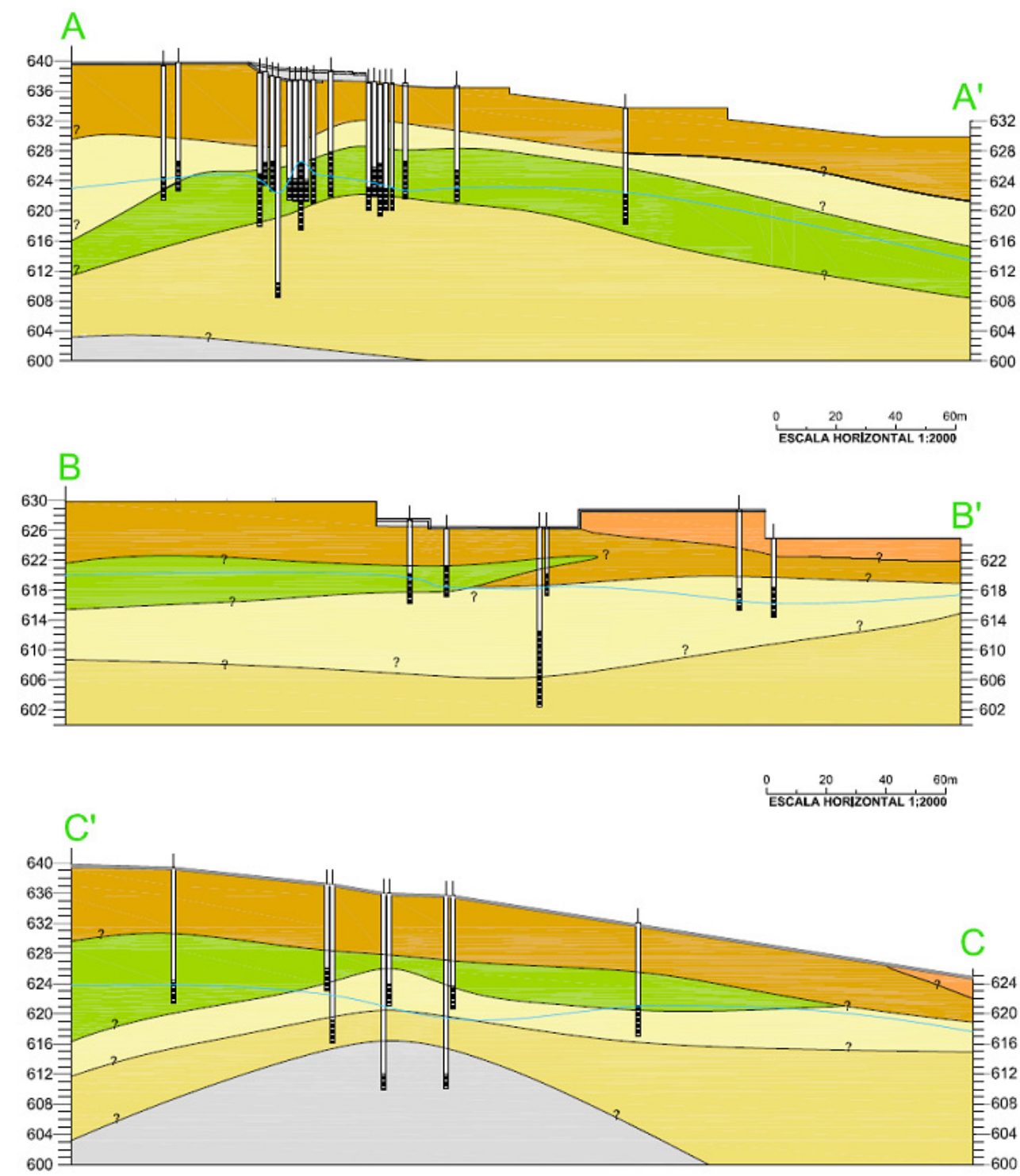

Manto de intemperismo: Areia fina siltosa pouco argilosa, de baixa plasticidade e umidade, apresenta cor marom avermelhada.

$\frac{0}{20} \stackrel{40}{\frac{40}{\text { ESCALA HORIZZNTAL }}, \frac{60 \mathrm{~m}}{1 ; 2000}}$

Manto de intemperismo: Silte argiloso, com presenca de areia fina, estruturas de laminação, alta plasticidade, com coloração branca, roxa, vermeltha, e cinza amarelada.

Manto de Intemperlsmo: Arela flna argllosa com presença de silte na matrlz, com balxa plastlcldade, cor amarela a avermelha.

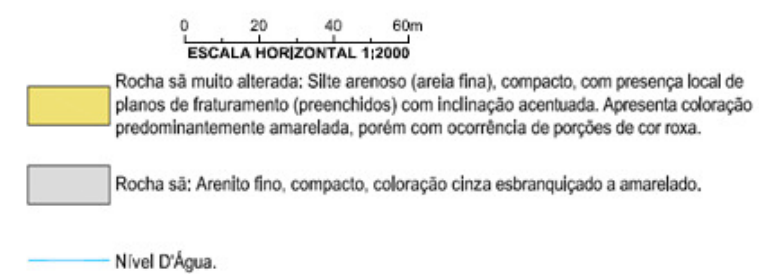

Figura 5 - Diagrama representativo da estratigrafia da Área 1 


\subsubsection{CARACTERIZAÇÃO DA CONTAMINAÇÃO}

A partir de avaliações preliminares realizadas na área em 1997, foram observados indícios de uma potencial contaminação da água subterrânea devido à manipulação inadequada de solventes clorados, como: tricloroeteno (TCE) e 1,1,1-tricloroetano (1,1,1TCA). O produto tetracloroeteno (PCE) também foi utilizado como desengraxante na área, mas em escala reduzida, quando comparado aos anteriores.

As atividades de investigação da água subterrânea mostraram que, embora tenham sido detectados os produtos solventes utilizados originalmente na área, são os compostos originados pela degradação natural que apresentaram as maiores concentrações: 1,1dicloroeteno (1,1-DCE), cis-1,2-dicloroeteno (cis-1,2-DCE), trans-1,2-dicloroeteno (trans-1,2DCE), 1,1-dicloroetano (1,1-DCA) e cloreto de vinila (VC).

Desde o início das atividades foram instalados poços de monitoramento na área com a finalidade de identificar quais locais estariam impactados e conseqüentemente delimitar a extensão da pluma de contaminação. Assim, foram instalados quarenta e sete poços de monitoramento ao longo das campanhas de investigação realizadas entre 1997 e 2006.

Por se tratar de contaminação por solventes clorados, de densidades superiores à da água subterrânea, tanto o aquífero freático como o intermediário foram investigados. Para avaliar a qualidade da água subterrânea no aquífero freático foram instalados poços de monitoramento com seção filtrante não afogada entre 15 e 18 m de profundidade, conforme variação do nível d’água local.

Devido à inexistência de uma camada impermeável de extensão e espessura, que configurassem o padrão de um aquitarde e dificultasse uma possível percolação vertical dos contaminantes clorados para níveis mais profundos, foi necessária a instalação de poços de monitoramento que apresentassem informações da qualidade da água subterrânea no nível intermediário. Portanto, poços de monitoramento com seção filtrante afogada foram instalados entre 24 e $30 \mathrm{~m}$ de profundidade. Neste nível do aquífero foram identificadas traços de concentrações de compostos orgânicos voláteis (Volatile Organic Compounds VOC). Com a instalação de poços de monitoramento em níveis distintos do aquífero, foi possível observar que a componente vertical do fluxo da água subterrânea, mesmo que não tão acentuado, é descendente.

Tendo como base a natureza e as características dos contaminantes e a identificação da área impactada, em 2007 foi realizada uma avaliação de risco à saúde humana com o objetivo de avaliar a necessidade de intervenção através da implantação de uma metodologia de remediação para a reabilitação da área contaminada. Segundo os cálculos, TCE foi um dos principais compostos que apresentaram valores significativos de 
risco (relacionados à inalação de vapores presentes na água subterrânea por parte dos trabalhadores industriais), embora as maiores concentrações identificadas na água subterrânea da área fossem de 1,1-DCA e 1,1-DCE. As concentrações consideradas nestes cálculos de risco foram: $4.144 \mu \mathrm{g} / \mathrm{L}$ de TCE; $12.700 \mu \mathrm{g} / \mathrm{L}$ de 1,1-DCA; e $10.600 \mu \mathrm{g} / \mathrm{L}$ de 1,1-DCE.

A partir destes resultados, foram avaliadas alternativas que apresentassem eficiência tanto no tratamento de cloroetenos, quanto clororetanos presentes na água subterrânea, nas fases dissolvida e adsorvida. Para o composto TCE, foi então, calculada meta de remediação de $290 \mu \mathrm{g} / \mathrm{L}$.

Em nenhuma das atividades de investigação realizadas na área, foram identificados contaminantes organoclorados presentes no solo.

Para a implementação de uma possível técnica de remediação, foram considerados, conjuntamente com as características específicas da área contaminada e físico-químicas dos contaminantes, fatores como eficácia, implementabilidade técnica, restrições de tempo, aceitação do órgão ambiental e custo.

\subsection{CARACTERIZAÇÃo dA ÁREA 2}

A segunda área de estudo (Área 2), embora não tenha histórico de ocupação industrial, foi utilizada entre 1990 e 1998 para a estocagem temporária de tambores com resíduos de solventes clorados utilizados como desengraxante. Parte desta segunda área foi aterrada com resíduos provenientes de processo de fundição e entulho de construção civil.

Topograficamente, a Área 2 está separada em dois níveis, com uma diferença de elevação entre 6 e 8m (Figura 6). Cerca de 20.000 tambores contendo resíduos provenientes de tratamento químico de materiais (galvanoplastia) e desengraxe de peças, foram estocados no nível superior do terreno (porção nordeste da área). Solventes clorados eram também manipulados em uma área a nordeste do terreno, onde eram realizadas lavagens de veículos. No nível inferior, a sudeste da área, encontra-se o local onde foram aterrados cerca de $10.000 \mathrm{~m}^{3}$ de areia de fundição (areia contendo carvão vegetal em pó, bentonita, ferro e alumínio). Análises químicas realizadas na área não identificaram este aterro como fonte de contaminação do solo ou água subterrânea local.

Assim como na Área 1, as APs específicas para este local foram identificadas e são apresentadas na Tabela 2. 
Tabela 2 - Descrição das áreas potencialmente contaminadas da Área 2

\begin{tabular}{cc}
\hline Área & Descrição \\
\hline AP-1 & Antigo aterro de areia de fundição \\
AP-2 & Antiga área de armazenamento de \\
& tambores \\
AP-3 & Antiga área de lavagem de veículos \\
\hline
\end{tabular}

As localizações das APs citadas na Tabela 2 são apresentadas na Figura 6.

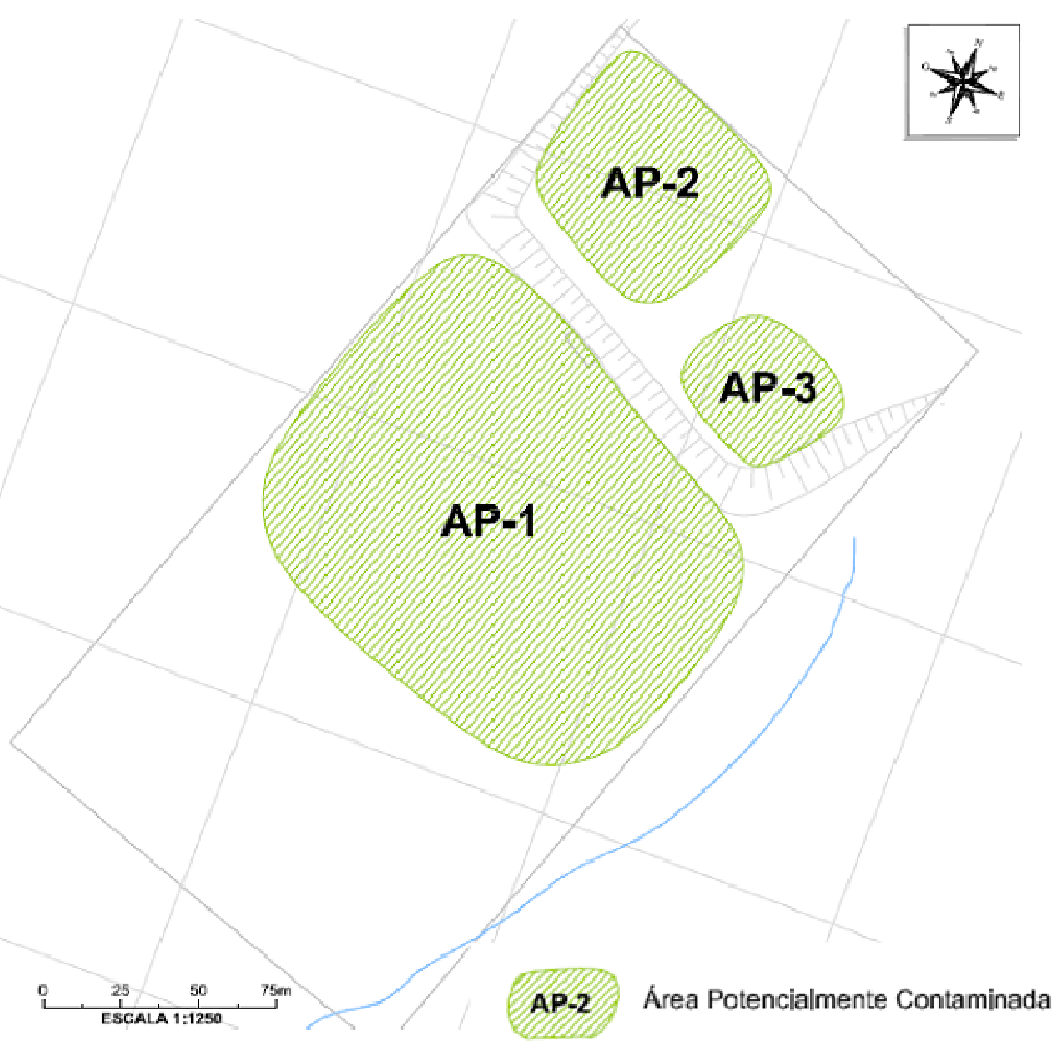

Figura 6 - Identificação das áreas potencialmente contaminadas (Área 2)

\subsubsection{GEOLOGIA E HIDROGEOLOGIA LOCAL}

A partir de descrições geológicas realizadas durante as perfurações do solo para instalação de poços de monitoramento foram identificados três níveis, do topo para a base, com as seguintes características:

- Aterro: Encontrado na maior parte da área, mas principalmente na porção central do platô inferior. Este material, composto por areia fina, friável e de coloração bege acinzentada (areia de fundição), foi encontrado em até $2 \mathrm{~m}$ de profundidade; 
- Aterro: Silte argiloso, marrom avermelhado de baixa a média plasticidade, com espessura variando entre 1 e $5 \mathrm{~m}$. Esse aterro pode ser classificado como material de corte e aterro vindo da própria área;

- Manto de intemperistmo: Silte argiloso, com presença de areia fina, estruturas de laminação, alta plasticidade e coloração branca, roxa, vermelha e cinza amarelada. Material encontrado abaixo do aterro com profundidade variando entre 7 e $18 \mathrm{~m}$;

- Rocha Sã: Siltito pouco intemperizado. Rocha sedimentar de coloração roxa, granulometria muito fina e alta compacidade.

Diferentemente da Área 1, o siltito observado na Área 2 apresenta-se de forma contínua em toda a área investigada. Por esta camada apresentar estrutura e característica hidráulica específica de um aquitarde, perfurações que pudessem ultrapassá-la não foram consideradas, com o objetivo de evitar uma possível mobilização dos contaminantes presentes no aquífero freático para níveis mais profundos. O siltito foi considerado como uma barreira natural no caminhamento dos organoclorados.

As características geológicas do material natural identificado na área indicam correlação com as litologias referentes ao membro inferior da Formação Tatuí, reconhecida por Barbosa e Gomes (1958, apud IPT, 1981) e Soares (1972b, apud IPT, 1981). A Figura 7 apresenta uma seção esquemática da estratigrafia encontrada na área.

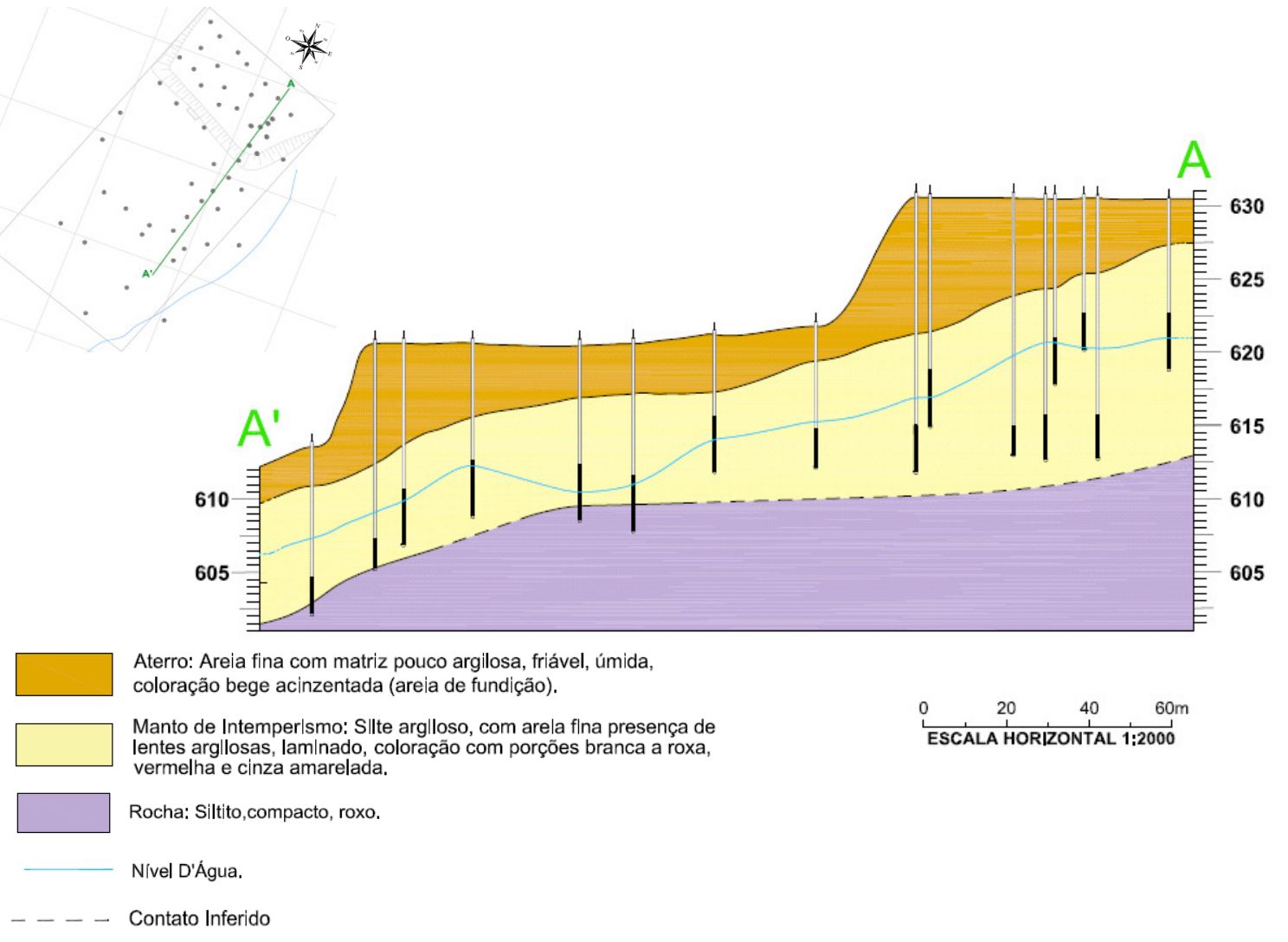

Figura 7 - Diagrama representativo da estratigrafia da Área 2 
A abordagem local da área de estudo permite a observação das possíveis áreas de recarga assim como alguns corpos d'água distribuídos pelas proximidades atuando como locais de descarga.

De modo geral, a área de ocorrência da pluma de contaminação localiza-se em uma meia-encosta que corresponde à área de recarga do aquífero freático local (Figura 8). No limite sul, encontra-se a principal área de descarga da propriedade, um riacho intermitente de direção NE-SW. O mapa potenciométrico do local (Figura 8), obtido com dados de março de 2008, indica que a direção preferencial do fluxo da água subterrânea é $\mathrm{N}$-S, com valores de cargas hidráulicas medidas variando entre 598,24 a 623,90 m. As cargas hidráulicas obtidas nos poços de monitoramento multiníveis instalados em níveis distintos do aquífero freático indicam a existência de um potencial vertical descendente para o fluxo da água subterrânea no local.

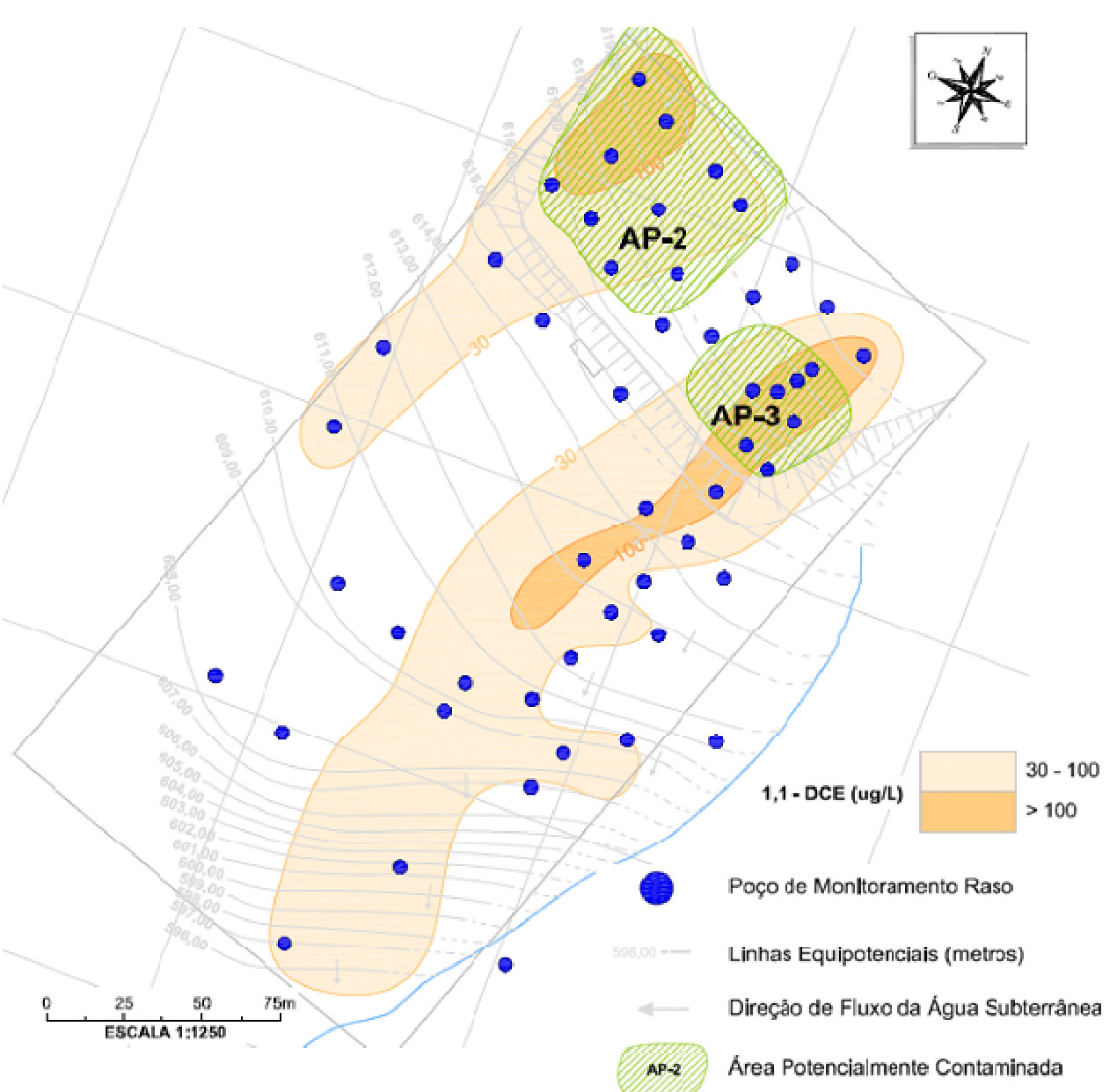

Figura 8 - Apresentação da direção preferencial do fluxo da água subterrânea do aquífero freático e a configuração da pluma de contaminação de 1,1-DCE antes da injeção do oxidante em toda a área (situação em março de 2008)

Testes hidráulicos realizados em seis poços de monitoramento existentes na área apresentaram valores de condutividade hidráulica variando entre $8,65 \times 10^{-5} \mathrm{~cm} / \mathrm{s}$ (poço 
localizado no limite noroeste) e $1,06 \times 10^{-4} \mathrm{~cm} / \mathrm{s}$ (poço localizado no limite sudeste). O valor médio de condutividade hidráulica obtido foi de $1,71 \times 10^{-4} \mathrm{~cm} / \mathrm{s}$. De acordo com os valores de carga hidráulica obtidos, foi calculada uma velocidade potencial média do fluxo da água subterrânea de $30 \mathrm{~m} / \mathrm{ano}$. Segundo USEPA (2008), locais que apresentem valores de condutividade hidráulica superiores a $1,00 \times 10^{-7} \mathrm{~cm} / \mathrm{s}$ podem ser considerados apropriados para a aplicação de tecnologias de remediação que envolvam injeção de fluidos no aquífero.

\subsubsection{CARACTERIZAÇÃo dA CONTAMINAÇÃO}

O principal composto de interesse identificado nesta área ao longo das campanhas de investigação ambiental foi o 1,1-DCE, originado dos produtos solventes TCE e 1,1,1TCA, a partir, respectivamente, de reações bióticas e abióticas naturais. Isto mostra que, embora a atenuação natural não tenha sido efetiva na completa destruição dos contaminantes, ela esteve presente.

A Figura 8 traz a configuração da pluma de 1,1-DCE identificada na campanha de monitoramento da água subterrânea de abril de 2008, anterior às atividades de remediação aplicadas em toda a área contaminada.

Os primeiros indícios de contaminação da água subterrânea foram observados em 1997, quando ocorreu a primeira investigação ambiental na área. A partir de então, foi necessária a instalação de cinqüenta e dois poços de monitoramento para identificar e delimitar a área impactada. Por se tratar de contaminantes de densidade superior à da água, foram instalados poços de monitoramento tanto no nível superior (entre 8 e $12 \mathrm{~m}$ de profundidade) quanto inferior do aquífero freático (entre 15 e $21 \mathrm{~m}$ de profundidade), onde é iniciado o topo da camada do aquitarde. Como mencionado, esta camada, de característica hidráulica de baixa permeabilidade, limitou as atividades de investigação com o objetivo de evitar uma potencial percolação dos contaminantes dissolvidos no aquífero freático para níveis mais profundos.

Com a identificação da presença de solventes organoclorados na água subterrânea local, foi realizada, em 2003, uma avaliação de risco à saúde humana para avaliar a necessidade de intervenção a partir da implementação de uma metodologia de remediação. Os resultados dos cálculos mostraram que a presença do composto 1,1-DCE na água subterrânea poderia ocasionar um risco potencial de inalação de vapores por parte de trabalhadores presentes na área. A meta de remediação obtida para este composto foi de $290 \mu \mathrm{g} / \mathrm{L}$. A maior concentração detectada de 1,1-DCE na água subterrânea foi de $880 \mu \mathrm{g} / \mathrm{L}$, na campanha de monitoramento de maio de 2005.

Posteriormente a este cálculo, as características toxicológicas deste composto foram alteradas pela Agência de Proteção Ambiental dos Estados Unidos e o mesmo passou a ser considerado como composto não carcinogênico. Considerando tais alterações, 
a avaliação de risco à saúde humana foi atualizada obtendo-se um novo valor de meta de remediação de $12.500 \mu \mathrm{g} / \mathrm{L}$ para o composto 1,1-DCE.

Em nenhuma das amostras de solo coletadas foi identificada concentração de compostos organoclorados.

Com a identificação de risco em valor superior aos níveis gerenciáveis de contaminação, realizada em 2003, foi necessária a consideração de medidas de remediação para redução das concentrações de 1,1-DCE presentes no aquífero freático. Para a implantação da metodologia de remediação foram considerados critérios como: eficácia, implementabilidade técnica, restrições de tempo, aceitação do órgão ambiental e custo.

A constatação da necessidade de reabilitação da área ocasionou em uma série de atividades envolvendo ensaios técnicos em campo e laboratório necessários para avaliar se determinada metodologia de remediação seria a mais adequada para o tratamento dos contaminantes presentes nas fases dissolvida e adsorvida.

\subsection{Avaliação Preliminar de Potencials técnicas de Remediação}

Anteriormente à seleção das técnicas químicas de remediação empreendidas nas áreas de estudo, foram realizados testes em campo e em laboratório para avaliar a possibilidade de implementação de outras alternativas de remediação.

Pelos resultados históricos das campanhas de monitoramento da água subterrânea na Área 1, notou-se a presença de toda a cadeia de degradação dos contaminantes solventes clorados. Esta constatação permitiu a realização de atividades que fornecessem dados sobre a possibilidade da implantação da Atenuação Natural Monitorada.

Os mesmos contaminantes solventes originais manipulados na Área 1 foram também manipulados na Área 2, embora nesta segunda área não tenham sido observados todos os compostos da cadeia de degradação, apenas 1,1-DCE em concentrações acima do limite de intervenção estabelecido pelo órgão ambiental. Dessa forma, partiu-se para uma avaliação preliminar da área relacionada à técnica de remediação Air Sparging, que envolve a aeração do aquífero pela injeção de oxigênio visando reações físico-químicas e volatilização dos contaminantes presentes.

\subsection{1 Área 1 - Atenuação Natural com Possível InJeÇÃo de Bioestimulantes}

Segundo informações levantadas em avaliações preliminares nesta área de estudo, foi identificada que a contaminação de compostos organoclorados presentes na água subterrânea na fase dissolvida foi resultado da manipulação inadequada dos produtos solventes TCE, 1,1,1-TCA e PCE, embora este último em menor quantidade. A identificação de compostos como 1,1-DCA; 1,1-DCE; e VC, indicou que a atenuação natural a partir da decloração redutiva biótica e abiótica poderia estar presente. Assim, foram realizados testes 
em laboratório com amostras de solo saturado contaminado para avaliar a presença de microorganismos capazes de degradar os solventes clorados.

\section{Teste de tratabilidade em laboratório para avaliação da atenuação natural}

Para verificar o potencial de degradação dos contaminantes organoclorados a partir da atenuação natural e avaliar a possibilidade de bioestimulação através da injeção de fonte de carbono orgânico dissolvido foram coletadas amostras de solo saturado no local mais impactado da pluma de compostos orgânicos voláteis da área de estudo (AP-4) e enviadas ao laboratório para testes de tratabilidade.

Os ensaios realizados em laboratório mostraram que a bioestimulação com microorganismos nativos, incluindo Dehalococcoides Ethenogenes, não seriam suficientes para aumentar a taxa de degradação dos contaminantes organoclorados presentes no meio, de forma que atingissem concentrações aceitáveis aos órgãos ambientais em tempo considerado viável.

Foram realizadas ainda análises de Carbono Orgânico Total (Total Organic Carbon - TOC) e Demanda Química de Oxigênio (DQO), mas os resultados indicaram baixas concentrações de TOC (<100 mg/kg) e DQO (<10 mg/kg). Dessa forma, outros testes deveriam ser realizados para avaliar qual a melhor abordagem de tratamento (químico ou biológico).

\section{Caracterização bioquímica do aquífero}

Para confirmar as condições do aquífero frente à possibilidade da aplicação da bioremediação, a partir da injeção de fonte de carbono, a água subterrânea foi coletada em alguns poços de monitoramento existentes em posições distintas na área contaminada (montante, centro e jusante da pluma).

Foram realizadas análises químicas de alcalinidade, Carbono Orgânico Dissolvido (Dissolved Organic Carbon - DOC), cloreto, ferro dissolvido, manganês, nitrato, nitrito, sulfato, sulfeto, metano, etano e eteno.

O processo de caracterização bioquímica da água subterrânea consiste basicamente na análise das linhas de evidência de degradação natural. Para este processo, foi usado como referência o "Manual Técnico para Avaliação de Atenuação Natural de Solventes Clorados em Água Subterrânea”, publicado pela USEPA (1998).

Os resultados mostraram que embora tenham sido identificados fortes indícios da ocorrência da biodegradação em poços de monitoramento existentes no centro da pluma, não apresentaram as condições ideais para a biodegradação anaeróbia, consolidando os resultados de tratabilidade obtidos anteriormente.

Com isso, uma nova alternativa de remediação deveria ser avaliada para reabilitação da área. 


\subsection{2 ÁREA 2 - AIR SPARGING}

Para avaliar as condições e respostas do meio quanto a esta alternativa de remediação, foram realizados testes de injeção de ar na zona saturada do meio impactado.

Os resultados dos testes não indicaram a tecnologia Air Sparging como sendo uma alternativa possível no processo de remediação desta área. Entre os fatores limitantes, tevese a dificuldade de injeção e percolação de ar no meio, devido às características geológicas presentes (intercalações de níveis de areia e argila) e o pequeno raio de influência do ar comprimido injetado (inferior a um metro). Não foi observada também aumento da aeração do aquífero (aumento do oxigênio dissolvido medido em campo), o que dificultaria de forma considerável a volatilização e a degradação dos compostos voláteis presentes na zona saturada.

Os resultados obtidos em ambas as áreas não foram satisfatórios e, portanto, novas avaliações se fizeram necessárias para que a área pudesse ser reabilitada. $O$ item a seguir apresentará a base conceitual da degradação dos contaminantes solventes organoclorados a partir da decloração redutiva biótica e abiótica, para que se entendam os processos químicos que foram aplicados nas áreas de estudo.

\section{REVISÃo BIBLIOGRÁFICA}

Neste item serão apresentadas as principais características e propriedades físicoquímicas dos compostos contaminantes de interesse para o trabalho, bem como seus comportamentos frente aos diferentes processos de degradação. O conhecimento do processo de atenuação natural é de grande importância, já que mesmo metodologias químicas de remediação, muitas vezes são embasadas em conceitos e atividades advindos da degradação natural de contaminantes orgânicos.

\subsection{Propriedades Químicas e Comportamento Geoquímico dos Contaminantes}

Observando as propriedades físico-químicas dos compostos de interesse é possível entender seus comportamentos nos vários meios contaminados e identificar possíveis metodologias de reabilitação das áreas impactadas.

A Tabela 3 apresenta algumas características dos principais produtos solventes utilizados, bem como de seus subprodutos gerados pela degradação natural através da ação de microorganismos (biótica) e reações químicas (abiótica). 
Tabela 3 - Propriedades básicas dos compostos de interesse

\begin{tabular}{|c|c|c|c|c|c|c|c|}
\hline $\begin{array}{l}\text { Nome } \\
\text { Comum }\end{array}$ & PCE & TCE & 1,1-DCE & $\begin{array}{c}\text { cis-1,2- } \\
\text { DCE }\end{array}$ & $\begin{array}{c}\text { trans-1,2- } \\
\text { DCE }\end{array}$ & VC & 1,1-DCA \\
\hline $\mathrm{N}^{\circ} \mathrm{CAS}$ & $127-18-4^{(2)}$ & $79-01-6^{(2)}$ & $75-35-4^{(2)}$ & $156-59-2^{(2)}$ & $156-60-5^{(2)}$ & $75-01-4^{(2)}$ & $75-34-3^{(2)}$ \\
\hline Fórmula & $\mathrm{C}_{2} \mathrm{Cl}_{4}^{(3)}$ & $\mathrm{C}_{2} \mathrm{HCl}_{3}{ }^{(3)}$ & $\mathrm{C}_{2} \mathrm{H}_{2} \mathrm{Cl}_{2}{ }^{(4)}$ & $\mathrm{C}_{2} \mathrm{H}_{2} \mathrm{Cl}_{2}{ }^{(4)}$ & $\mathrm{C}_{2} \mathrm{H}_{2} \mathrm{Cl}_{2}{ }^{(4)}$ & $\mathrm{C}_{2} \mathrm{H}_{3} \mathrm{Cl}^{(4)}$ & $\mathrm{C}_{2} \mathrm{H}_{4} \mathrm{Cl}_{2}{ }^{(4)}$ \\
\hline $\begin{array}{l}\text { Fórmula } \\
\text { Estrutural }\end{array}$ & 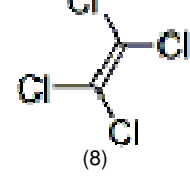 & (8) & $\prod_{(8)}$ & (8) & (8) & & $\mathrm{Cl}$ \\
\hline $\begin{array}{c}\text { Peso Molar } \\
(\mathrm{g} / \mathrm{mol})\end{array}$ & $165,8^{(1)}$ & $131,5^{(1)}$ & $97^{(1)}$ & $97^{(1)}$ & $97^{(1)}$ & $62,5^{(4)}$ & $99^{(1)}$ \\
\hline $\begin{array}{c}\text { Densidade } \\
\left(\mathrm{g} / \mathrm{cm}^{3}\right)\end{array}$ & $1,63^{(1)}$ & $1,46^{(1)}$ & $1,22^{(1)}$ & $1,28^{(1)}$ & $1,26^{(1)}$ & $0,983^{(10)}$ & $1,17^{(1)}$ \\
\hline $\begin{array}{l}\text { Ponto de } \\
\text { Ebulição } \\
\quad\left({ }^{\circ} \mathrm{C}\right)\end{array}$ & $121,4^{(1)}$ & $86,7^{(1)}$ & $31,9^{(1)}$ & $60^{(1)}$ & $48^{(1)}$ & $-13,3^{(4)}$ & $57,3^{(1)}$ \\
\hline $\begin{array}{l}\text { Ponto de } \\
\text { Fusão }\left({ }^{\circ} \mathrm{C}\right)\end{array}$ & $-22,3^{(4)}$ & $-84,7^{(4)}$ & $-122,5^{(4)}$ & $-80^{(4)}$ & $-49,8^{(4)}$ & $-153,7^{(4)}$ & $-96,9^{(4)}$ \\
\hline $\log K_{o w}$ & $3,4^{(4)}$ & $2,42^{(4)}$ & $2,13^{(4)}$ & $1,86^{(4)}$ & $2,09^{(4)}$ & $1,62^{(4)}$ & $1,79^{(4)}$ \\
\hline $\mathrm{K}_{\mathrm{ow}}$ & 2511 & 263 & 135 & 72 & 123 & 42 & 62 \\
\hline $\mathrm{K}_{\mathrm{oc}}(\mathrm{ml} / \mathrm{g})$ & $364^{(1)}$ & $126^{(1)}$ & $65^{(1)}$ & $86^{(1)}$ & $59^{(1)}$ & $23,7^{(9)}$ & $30^{(1)}$ \\
\hline $\mathrm{K}_{\mathrm{d}}(\mathrm{ml} / \mathrm{g})$ & $3,64^{(7)}$ & $1,26^{(7)}$ & $0,65^{(7)}$ & $0,86^{(7)}$ & $0,59^{(7)}$ & $0,23^{(7)}$ & $0,30^{(7)}$ \\
\hline $\begin{array}{c}\text { Solubilidad } \\
\text { e a } 25^{\circ} \mathrm{C} \\
(\mathrm{mg} / \mathrm{L})\end{array}$ & $200^{(1)}$ & $1100^{(1)}$ & $3350^{(1)}$ & $3500^{(1)}$ & $6300^{(1)}$ & $1100^{(6)}$ & $5100^{(1)}$ \\
\hline $\begin{array}{c}\mathrm{H}(\text { atm } \\
\left.\mathrm{m}^{3} / \mathrm{mol}\right) \mathrm{a} \\
25^{\circ} \mathrm{C}\end{array}$ & $0,0174^{(1)}$ & $0,00937^{(1)}$ & $0,0255^{(1)}$ & $0,00374^{(1)}$ & $0,00916^{(1)}$ & $1,22^{(6)}$ & $0,00543^{(1)}$ \\
\hline $\begin{array}{l}\text { Pressão de } \\
\text { Vapor (mm } \\
\mathrm{Hg}) \text { a } 25^{\circ} \mathrm{C}\end{array}$ & $18,5^{(4)}$ & $69^{(4)}$ & $600^{(4)}$ & $200^{(4)}$ & $331^{(4)}$ & $2980^{(4)}$ & $227^{(4)}$ \\
\hline $\begin{array}{c}\text { Coeficiente } \\
\text { de difusão } \\
\text { na água } \\
\left(\mathrm{cm}^{2} / \mathrm{s}\right)\end{array}$ & $\underset{(5)}{0,0000082}$ & $\underset{(5)}{0,0000091}$ & $\underset{(5)}{0,0000104}$ & $\underset{(5)}{0,0000113}$ & $\underset{(5)}{0,0000119}$ & $\begin{array}{c}0,0000012 \\
3^{(5)}\end{array}$ & $\underset{(5)}{0,0000105}$ \\
\hline \multicolumn{8}{|c|}{ 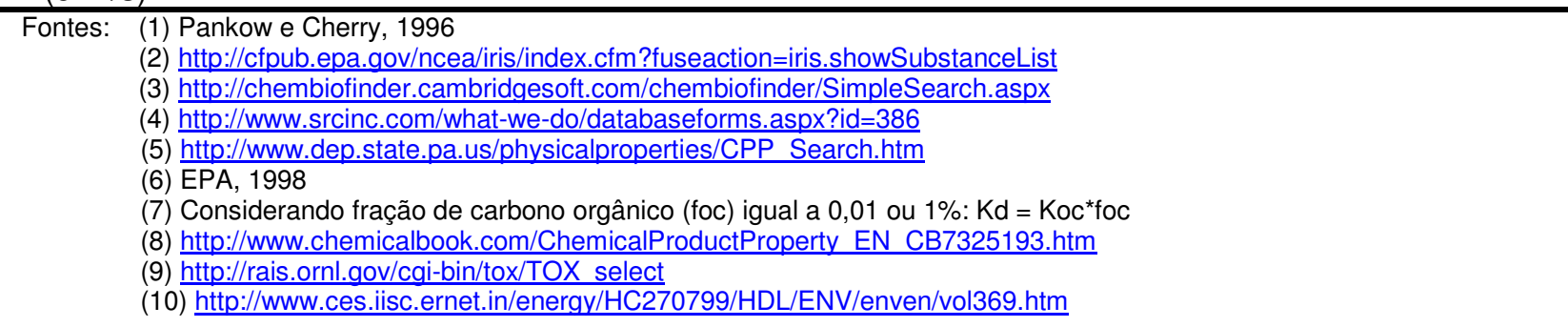 } \\
\hline
\end{tabular}


Algumas das propriedades citadas na Tabela 3 revelam características importantes destes compostos, como descritas a seguir:

1) Densidade: Com exceção do cloreto de vinila, os demais compostos possuem altos valores de densidade $\left(1,17\right.$ a $\left.1,63 \mathrm{~g} / \mathrm{cm}^{3}\right)$ em relação à água $\left(1 \mathrm{~g} / \mathrm{cm}^{3}\right)$ o que permite que os solventes clorados percolem em fluxo vertical descendente pela zona saturada em direção a níveis mais profundos do aquífero. Quando encontra níveis de permeabilidade mais baixa, tende a se concentrar formando bolsões ou pools de produtos em fase livre ou fase densa não aquosa (Dense Non-Aqueous Phase Liquid - DNAPL), que contribuem para o aumento da contaminação em fase dissolvida presente na água subterrânea (Pankow e Cherry, 1996);

2) Coeficiente de partição octanol-água $\left(\mathrm{K}_{\mathrm{ow}}\right)$ : Os valores de $\mathrm{K}_{\mathrm{ow}}$, apresentados na Tabela 3, indicam maior tendência dos compostos de permanecerem dissolvidos na água subterrânea do que adsorvidos no solo. Fato que aumenta sua mobilidade no meio saturado e diminui seu fator de retardação. Apesar disso, observando individualmente cada composto, é possível identificar diferenças, como por exemplo, o cloreto de vinila que tende a ser mais móvel do que os demais compostos (principalmente o PCE), visto que apresenta um menor valor de $\mathrm{K}_{\mathrm{ow}}$;

3) Coeficiente de partição baseado no carbono orgânico $\left(K_{o c}\right)$ e coeficiente de distribuição $\left(K_{d}\right)$ : Ambos os valores fazem menção à característica do composto em permanecer adsorvido na matéria orgânica existente em volta dos grãos devido à presença de carbono orgânico. Quanto menores os valores de $\mathrm{K}_{\mathrm{oc}}$ e $\mathrm{K}_{\mathrm{d}}$, menor será a massa de contaminante presente adsorvido no solo e maior será a concentração dissolvida na água subterrânea;

4) Solubilidade: Os valores de solubilidade variados, mas altos em comparação a outros compostos, indicam que a presença destes compostos, mesmo em fase dissolvida, pode ocasionar em alta concentração na água subterrânea, gerando risco potencial à saúde humana;

5) Constante de Henry $(\mathrm{H})$ : Esta propriedade indica qual a tendência de volatilização dos compostos, fato que aumenta o risco à saúde de potenciais receptores que porventura venham a inalar estes solventes clorados, em contato com o produto puro ou de forma passiva presentes na água subterrânea;

6) Viscosidade: Por apresentarem baixos valores de viscosidade, seu caminhamento em subsuperfície pode se dar juntamente com o da água subterrânea. Sua mobilidade aumenta com o aumento da razão densidade/viscosidade (Pankow e Cherry, 1996); e 
7) Tensão interfacial: A baixa tensão interfacial facilita a entrada de compostos solventes organoclorados em fase líquida entre poros e pequenas fraturas, permitindo a contaminação em níveis profundos do embasamento rochoso (Pankow e Cherry, 1996).

A Figura 9 apresenta uma ilustração esquemática que resume os processos que direcionam a partição do contaminante no solo, ar e água em subsuperfície.

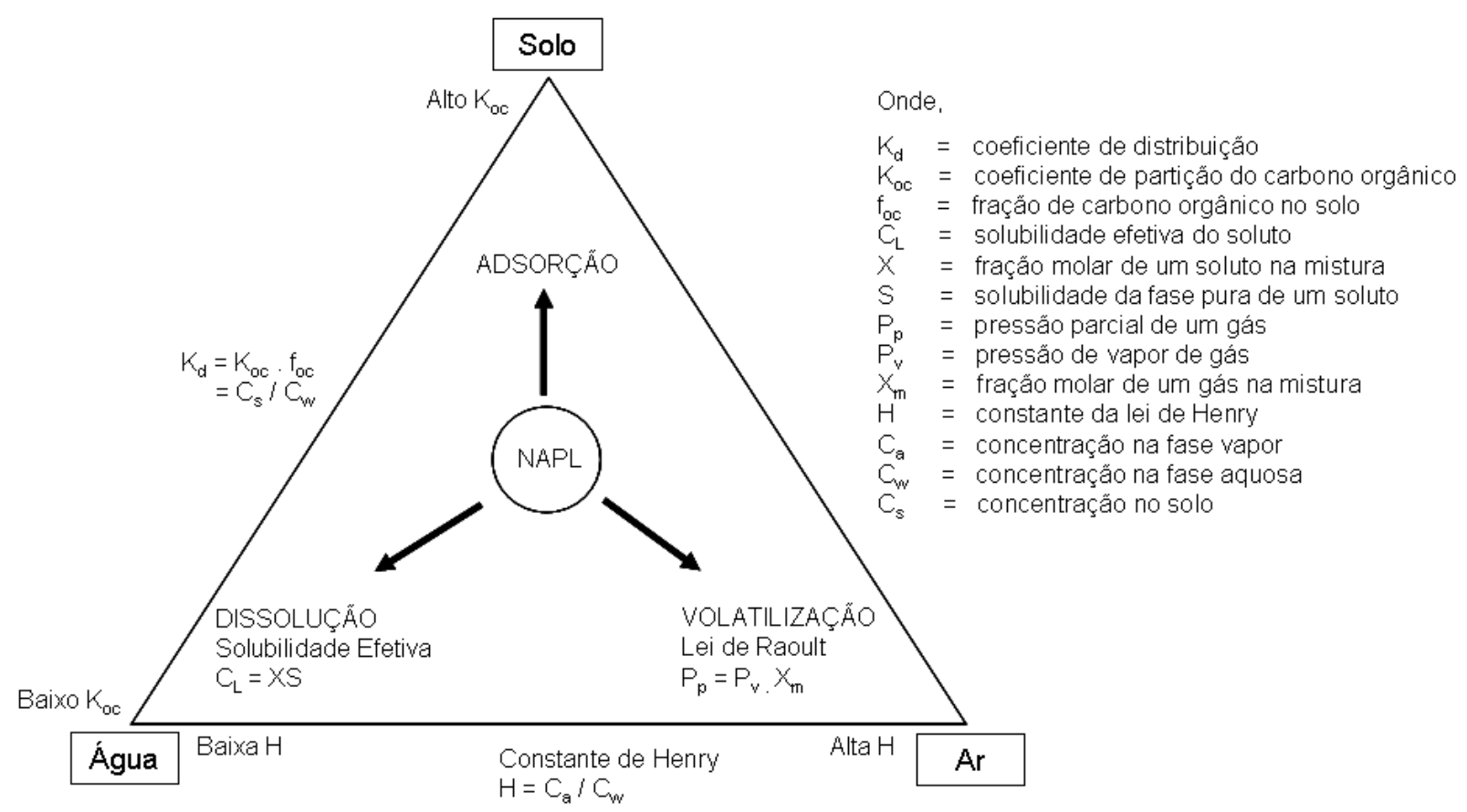

Figura 9 - Processos de partição do contaminante no solo, ar e água em subsuperfície. (Fonte: Modificado de USEPA, 2004)

Nos processos químicos de degradação, as alterações moleculares à que são submetidos os contaminantes orgânicos, são causadas por reações de oxidação (perda de elétrons) e redução (ganho de elétrons). Tanto a perda quanto o ganho de elétrons ocorrem devido ao estado de oxidação de cada composto. Desta forma, para se entender a degradação seqüencial dos contaminantes que envolvem a transferência de elétrons é importante conhecer o estado de oxidação do carbono em cada contaminante.

Os elétrons são compartilhados em ligações covalentes. Para qualquer átomo em uma molécula com ligações covalentes o estado de oxidação é identificado da seguinte forma: 0 quando a ligação ocorre entre átomos idênticos; -1 quando a ligação é a um átomo menos eletronegativo ou para cada carga negativa do átomo; e +1 quando a ligação é a um átomo mais eletronegativo ou para cada carga positiva. Uma vez que o valor de cada ligação é determinado, obtêm-se os valores que indicam o estado de oxidação de um átomo específico (Suthersan e Payne, 2005). 
A Figura 10 apresenta os estados de oxidação do carbono nos principais contaminantes organoclorados e seus compostos de degradação.

O número de oxidação do carbono nas moléculas pode assumir valores entre -4 e +4. Por exemplo, para o cálculo do número de oxidação do PCE, temos que cada carbono da molécula deste composto está ligado a dois átomos de cloro (cada átomo de cloro possui número de oxidação de -1; quando os números de oxidação dos dois átomos de $\mathrm{Cl}^{-}$são somados, temos número de oxidação -2). Como o número de oxidação da molécula é dado pela média da soma dos números de oxidação de cada um dos átomos de carbono $\left(X_{1}=+2 ; X_{2}=+2\right)$, tem-se o valor do número de oxidação do $\mathrm{PCE},+2$. O composto TCE possui número de oxidação igual a +1 , que é a média da soma do número de oxidação do átomo de carbono ligado aos dois átomos de $\mathrm{Cl}^{-}\left(\mathrm{XC}_{1}=+2\right)$ e do átomo de carbono ligado aos átomos de $\mathrm{Cl}^{-}$e $\mathrm{H}^{+}\left(\mathrm{XC}_{2}=0\right)$. Portanto, a formação do TCE a partir do PCE ocorre pela reação de decloração redutiva, que envolve a transferência de um elétron. Da mesma forma que o restante da transformação seqüencial (TCE $\rightarrow$ cis-DCE $\rightarrow$ VC $\rightarrow$ eteno $\rightarrow$ etano) é o resultado da transferência de um elétron (Suthersan e Payne, 2005).

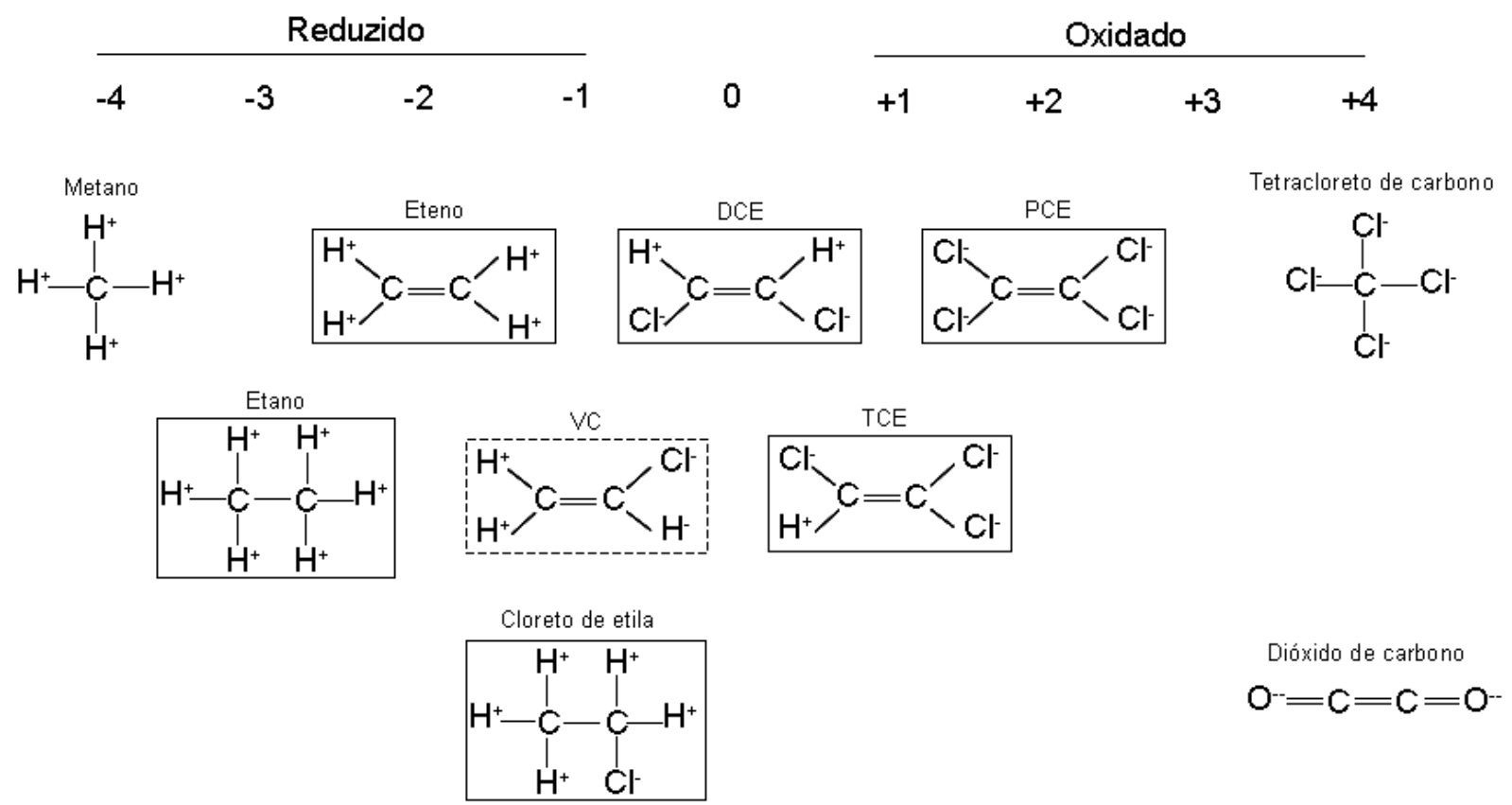

Figura 10 - Estados de oxidação de vários alcanos e alcenos clorados e $\mathrm{CO}_{2}$. (Fonte: Modificado de Suthersan e Payne, 2005)

Os compostos podem apresentar diferentes formas de degradação, que podem estar vinculadas às atividades biológicas de microorganismos, ou à processos estritamente químicos de natureza abiótica, como apresentados a seguir. 


\subsection{Metodologias de DegradaçÃo de Contaminantes Orgânicos}

\subsubsection{TÉCnica de Remediação Passiva: Atenuação Natural}

Os solventes clorados quando presentes na água subterrânea podem sofrer alterações em suas estruturas moleculares gerando novos compostos de propriedades físico-químicas muitas vezes distintas. Quando tal processo ocorre sem a intervenção do homem, dá-se o nome de degradação ou atenuação natural, que inclui uma variedade de reações físicas, químicas e biológicas, que sob condições favoráveis reduz a massa, toxicidade, mobilidade, volume e/ou concentração de contaminantes no solo ou na água subterrânea (USEPA, 2004).

Segundo Suthersan e Payne (2005), para que a degradação natural ocorra, microorganismos utilizam de diversas estratégias para remover os cloretos das moléculas dos solventes clorados e os usam para seu próprio benefício. Os mecanismos metabólicos mais comuns para a decloração são: (1) decloração oxigenolítica, onde sob condições aeróbias, o cloreto é substituído por uma hidroxila derivada do oxigênio; (2) decloração hidrolítica, onde o cloreto é substituído por uma hidroxila derivada da água; (3) decloração redutiva, onde, principalmente sob condições anaeróbias, o cloreto é substituído pelo hidrogênio; e (4) eliminação.

Solventes clorados como PCE e TCE podem ser naturalmente biodegradáveis via decloração redutiva, processo que necessita da presença de microorganismos, elétrons receptores (como por exemplo, hidrocarbonetos clorados alifáticos) e um adequado suprimento de elétrons doadores. Os elétrons doadores podem incluir combustíveis hidrocarbonetos ou outros tipos de carbono antropogênico ou carbono orgânico natural (USEPA, 1998).

Compostos altamente clorados como PCE, tetraclorometano (CT) e TCE encontram-se em alto grau de oxidação devido à presença dos átomos de cloro em suas moléculas. Quanto maior o grau de cloração, menor será a probabilidade de degradação em ambientes aeróbios, assim como o oposto é verdadeiro: compostos com menor grau de cloração tendem a ser menos degradados em ambientes anaeróbios (Suthersan e Payne, 2005).

A sequência natural de degradação dos compostos solventes clorados é a decloração redutiva do PCE para TCE, TCE para DCE, DCE para VC e por fim, de VC para eteno. Mas, esta sequência pode ser interrompida conforme as condições presentes no meio (USEPA, 1998). Ambientes anaeróbios redutores podem propiciar a degradação de PCE e TCE até DCE, mas podem ocasionar o acúmulo de VC (composto de maior toxicidade), já que a ausência de oxigênio no interior da pluma limitará sua degradação para eteno ou sua completa mineralização, formando dióxido de carbono e água (Suthersan; 
Payne, 2005).

A Figura 11 resume o caminho da sequência de degradação natural dos produtos solventes PCE, TCE e 1,1-TCA e a formação de subprodutos que pode ocorrer tanto de forma biótica quanto abiótica.

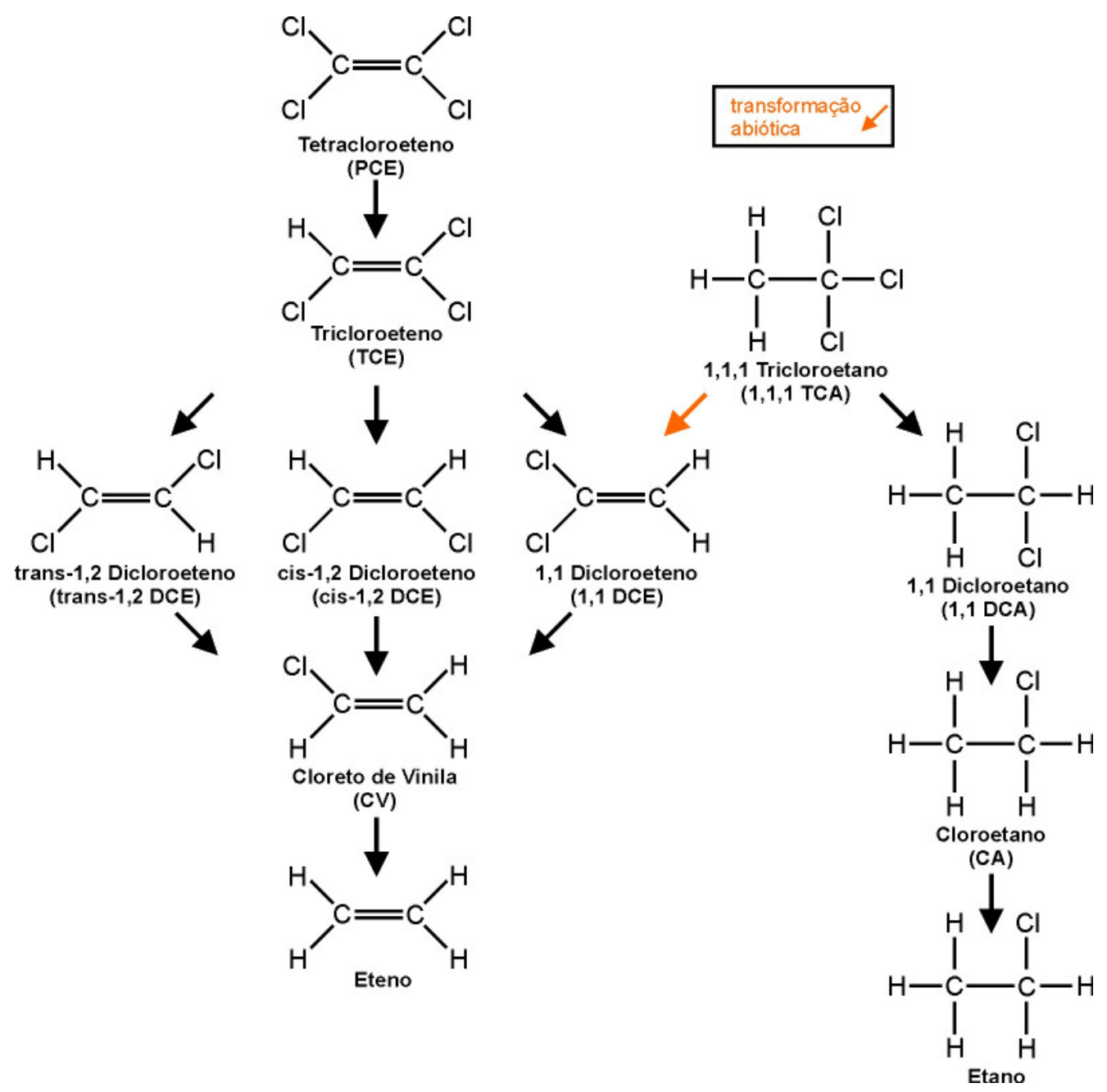

Figura 11 - Principais compostos e possíveis sequências de degradação. (Fonte: Modificado de USEPA, 1998)

Na presença de microorganismos que aceleram atividades biológicas responsáveis pela atenuação ou degradação natural de contaminantes organoclorados, esta técnica de remediação passiva pode ser utilizada e monitorada, embora na maioria dos casos seja necessária a aplicação de outra técnica de remediação mais intensa agindo concomitantemente, principalmente no centro da pluma onde ocorrem as maiores concentrações dos contaminantes.

De modo geral, o processo de degradação mais observado durante a atenuação natural é o que ocorre por atividades biológicas, com decloração redutiva sequencial (Tiedje 
e Mohn, 1992; Vogel e McCarthy, 1987). Este típico processo natural gera novos compostos devido à perda de íons cloreto, transformando um composto de maior complexibilidade (composto pai) em uma série de outros produtos mais simples (compostos filhos).

Segundo Buscheck e Alcantar (1995), na atenuação natural a degradação dos contaminantes ocorre sem a interferência humana ou melhorias artificiais do meio (remediação passiva) e pode agir através de dois processos distintos: 1) destrutivo - quando ocorre a redução tanto das concentrações dos contaminantes quanto de sua massa; e 2) não destrutivo - quando a redução é notada apenas em suas concentrações.

A biodegradação é o processo de atenuação destrutivo mais importante, embora a destruição de alguns compostos possa ocorrer de forma abiotótica. Processos de atenuação natural não destrutivos incluem adsorção, dispersão, diluição por recarga do aquífero e volatilização.

De acordo com USEPA (1998), os microorganismos responsáveis pela degradação de contaminantes orgânicos existem naturalmente no aquífero e assim como humanos, precisam tanto de fonte de alimento (carbono orgânico) quanto de energia, gerada pela transferência de elétrons entre compostos. Quando a biodegradação é completa, contaminantes dissolvidos são transformados em produtos inócuos como dióxido de carbono, cloretos, metano e água. A este processo dá-se o nome de mineralização. Como já mencionado, alguns subprodutos gerados durante a biodegradação podem ser mais tóxicos que os compostos originais, como é o caso do cloreto de vinila gerado pela degradação do solvente clorado PCE.

Segundo Keeley, Russell e Sewell (1999), a biodegradação de compostos orgânicos na água subterrânea ocorre através de três mecanismos:

1) Uso de composto orgânico como fornecimento de substrato primário;

2) Uso de composto orgânico como elétron receptor; e

3) Cometabolismo.

Os dois primeiros mecanismos de biodegradação envolvem a transferência microbiótica de átomos de elétrons doadores para elétrons receptores. Este processo pode ocorrer sob condições aeróbias ou anaeróbias. Elétrons doadores incluem material orgânico natural, combustíveis hidrocarbonetos, e etenos e etanos oxidados menos clorados. Elétrons receptores são compostos que ocorrem em relativo estado oxidado. Os elétrons receptores de ocorrência mais comum na água subterrânea incluem oxigênio dissolvido, nitrato, manganês IV, ferro III, sulfato e dióxido de carbono. Solventes clorados mais oxidados como PCE, TCE, DCE, TCA, DCA e benzenos policlorados podem agir como elétrons receptores na ausência de oxigênio. 
Ao contrário dos dois primeiros mecanismos, onde a degradação é meramente a reação de oxidação e redução entre as moléculas, no processo cometabólico, que ocorre em ambientes aeróbios, a degradação de algumas moléculas orgânicas (incluindo contaminantes) requer a produção e eficiente utilização de enzimas. Nestes casos, a enzima é necessária para a degradação do carbono orgânico, o qual é utilizado pela bactéria para se reproduzir e gerar energia (Keeley, Russell e Sewell, 1999).

Todos estes processos de biodegradação causam mudanças mensuráveis na química da água subterrânea. Durante a respiração aeróbia, oxigênio é reduzido para água e, portanto, a concentração de oxigênio dissolvido é reduzida. Em sistemas anaeróbios onde o nitrato é o receptor de elétron, este é reduzido para $\mathrm{NO}_{2}^{-}, \mathrm{N}_{2} \mathrm{O}, \mathrm{NO}, \mathrm{NH}_{4}{ }^{+}$, ou $\mathrm{N}_{2}$ (denitrificação ou nitrato redução). Neste caso, as concentrações de nitrato diminuem. Quando o ferro III é o elétron receptor, ocorre a redução para ferro II (ferro redução) e as concentrações de ferro III diminuem. Quando o sulfato é o elétron receptor, este é reduzido para $\mathrm{H}_{2} \mathrm{~S}$ (sulfato redução) e as concentrações de sulfato diminuem. Todos estes processos resultam no aumento da alcalinidade total, já que os átomos de $\mathrm{H}^{+}$disponíveis no meio substituirão átomos de cloro anteriormente existentes nas moléculas dos contaminantes ou formarão espécies mineralizadas. Em sistemas anaeróbios onde $0 \mathrm{CO}_{2}$ é usado como elétron receptor, este é reduzido pela bactéria metanogênica durante a metanogênese e $\mathrm{CH}_{4}$ é produzido (USEPA, 1998).

Quando cada subseqüente elétron receptor é utilizado, a água subterrânea passa a ter características redutoras.

Em sistemas anaeróbios onde contaminantes são usados como elétrons receptores, eles são reduzidos para produtos filhos menos clorados. Nestes ambientes, as condições do meio são bastante hostis, forçando grupos de microorganismos a se associarem e criarem ambientes mais propícios para que possam sobreviver. Neste sistema, diferentes tipos de microorganismos, responsáveis por diferentes reações, são capazes de mineralizar completamente os contaminantes, devido às diversas capacidades metabólicas. Apesar da possibilidade da degradação natural de contaminantes organoclorados até sua completa mineralização, estudos mostram que valores de meia-vida podem ser altos, podendo ocorrer em até milhares de anos. São observados valores de meia-vida entre 61 e $2,1 \times 10^{10}$ anos, respectivamente, para 1,1-DCA e 1,2-DCE (USEPA, 1998).

Outro ponto importante a ser considerado é que nem todas as áreas apresentam características propícias para o desenvolvimento de microorganismos específicos e degradação dos contaminantes orgânicos.

Como a avaliação e o monitoramento do processo de atenuação natural podem ser demasiadamente longos e custosos e muitas vezes não aceitos pelos órgãos ambientais 
como uma alternativa de remediação, são cada vez mais utilizadas metodologias químicas de tratamento in situ que promovem a redução da massa de contaminantes, além de apresentarem resultados mais rápidos e menos invasivos.

\subsubsection{Técnicas de Remediação Ativa: Processos Químicos}

A seguir serão apresentadas as bases conceituais das duas metodologias de remediação ativa, aplicadas nas áreas de estudo, a saber: redução química in situ e oxidação química in situ.

\subsubsection{REDUÇÃO QUÍMICA IN SITU}

Em pesquisas do processo de atenuação natural realizadas por Vogel, Criddle e McCarty (1987), foi identificada uma variedade de processos bióticos e abióticos que poderiam degradar compostos clorados alifáticos. Estes processos de degradação incluíram hidrogenólise (substituição de um átomo de cloro por um hidrogênio), dihaloliminação ou $\beta$ eliminação (eliminação de dois cloretos da molécula formada pela ligação C-C) e acoplagem (perda de dois cloretos em duas moléculas separadas pela ligação C-C). Estes três processos são reduções de dois elétrons com os elétrons supridos pelos processos microbióticos ou por redutores químicos.

$\mathrm{Na}$ atenuação natural abiótica de solventes clorados, o mecanismo inicial identificado foi a dehidrohalogenação (perda do $\mathrm{HCl}$ ), produzindo 1,1-DCE a partir do 1,1,1TCA e hidrólise para a formação do ácido acético, ambos ocorrendo sem a transferência de elétrons (Vogel e McCarty, 1987). A Figura 12 apresenta os potenciais caminhos de degradação abiótica dos cloroetenos. 


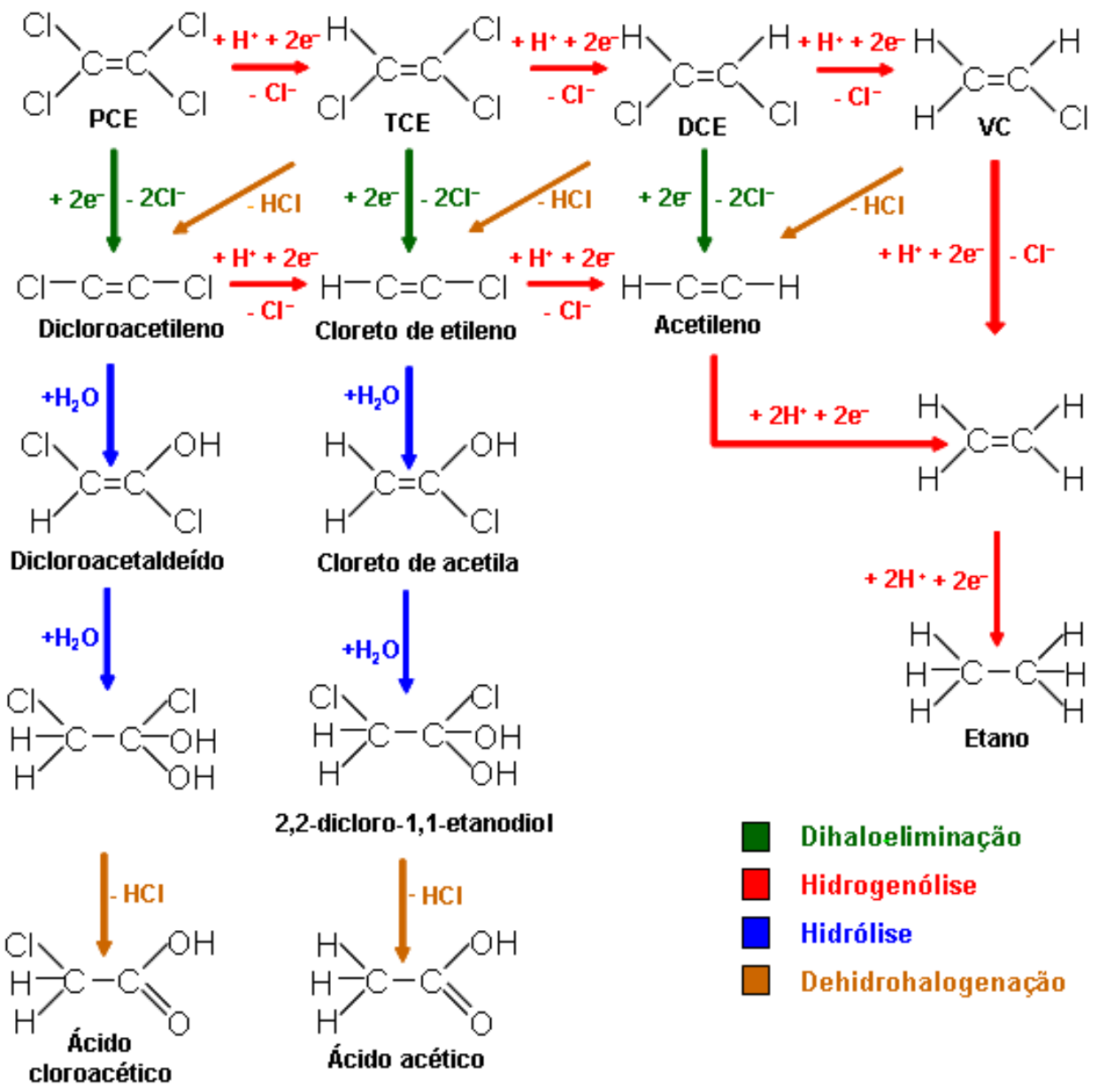

Figura 12 - Potenciais caminhos de degradação dos cloroetenos

Uma das primeiras metodologias de redução de contaminantes orgânicos e inorgânicos utilizando ferro reduzido foi o uso de barreiras reativas que utilizavam ferro zero valente (Zero Valent Iron - ZVI). Anteriormente ao advento das barreiras reativas, muitas áreas impactadas por solventes clorados utilizavam sistemas de bombeamento e tratamento da água subterrânea, o que tornavam a operação e manutenção intensamente dispendiosa (Muegge, 2008).

Brown et al. (2006) menciona que o desenvolvimento da redução química é baseado em quatro princípios: 1) todo processo redutivo abiótico envolve a forma de um metal reduzido, tipicamente o ferro, que pode ser o ferro zero valente ou o ferro ferroso; 2) os caminhos redutivos mediados pelo ferro são, em geral, diferentes daqueles que ocorrem pela redução mediada biologicamente; 3 ) os processos redutivos baseados no ferro são fortemente dependente do meio, mas podem ser realçados pelo uso de redutores químicos e/ou biológicos.

A redução química in situ é uma metodologia que utiliza um redutor químico para reduzir óxidos de ferro III, presentes naturalmente no aquífero sedimentar, e transformá-los 
em ferro II. Segundo Vermuel et al. (2000), para que este processo se desenvolva, é necessário que a ocorrência natural do ferro III seja de no mínimo 0,05 \% da fração do solo total.

O ferro é o quarto elemento mais abundante da crosta terrestre e compreende cerca de $5 \%$, em peso, das rochas. Esta abundância sugere que a ISCR pode ter uma boa aplicabilidade (Brown et al., 2006).

O fator de maior importância na degradação abiótica baseada na redução do ferro é que não há o acúmulo de subprodutos tóxicos, como cloreto de vinila, visto que há a eliminação contígua de dois átomos de $\mathrm{Cl}^{-}$das moléculas dos contaminantes orgânicos, e isso elimina uma das principais fontes de preocupação quando se fala em degradação de contaminantes organoclorados (Brown et al., 2006; Arnold e Roberts, 2000).

Brown e Lewis (2005) realizaram experimentos com amostras contaminadas por solventes clorados tratadas com ferro ferroso, ferro zero valente e ditionita de sódio $\left(\mathrm{Na}_{2} \mathrm{~S}_{2} \mathrm{O}_{4}\right)$. Os resultados mostraram que a ISCR pode ser um tratamento viável para uma grande gama de contaminantes, embora tenham sido notados diferentes graus de potencial de redução entre os compostos. Compostos como 1,1,1-TCA; 1,1-DCE; e CT, foram facilmente reduzidos em todos os sistemas redutores. Outros compostos como PCE, TCE, e clorofórmio (CF) também foram reduzidos, mas não responderam tão rapidamente como o primeiro grupo. E finalmente alguns solventes apresentaram resistência à redução, o que indica que tais compostos necessitem de condições mais específicas: cis-DCE; 1,1-DCA, e diclorometano (DCM). Entre os materiais utilizados nos experimentos, observou-se que a combinação do ferro reduzido, como o ZVI, com o agente redutor não metálico, ditionita de sódio, foram hábeis em degradar a maioria dos solventes clorados estudados. Também a adição da ditionita ao ferro natural resultou em uma maior redução dos contaminantes, do que usando o ferro ferroso puro.

Segundo Vermuel et al. (2000), o tratamento químico que envolve a ditionita dissolve e reduz óxidos de ferro III amorfos e cristalinos. O ferro reduzido criado pelo tratamento com a ditionita pode estar presente em duas diferentes fases: ferro II adsorvido e ferro II em carbonatos (siderita $-\mathrm{FeCO}_{3}$ ).

O redutor ativo que ocorre na atenuação natural abiótica é o ferro reduzido (ferro ferroso ou $\mathrm{Fe}^{+2}$ ), que existe naturalmente em um grande número de formações mineralógicas como magnetita e pirita. Minerais de ferro reduzido também podem ser produzidos por atividades biológicas como bactérias redutoras de ferro ou sulfato. Sob condições sulfato redutoras, o íon sulfeto reage com o ferro férrico $\left(\mathrm{Fe}^{+3}\right)$ reduzindo-o para ferro ferroso e formando a pirita $\left(\mathrm{FeS}_{2}\right)$ (Lee et al., 2002).

Os principais agentes redutores normalmente utilizados no tratamento da redução química in situ, incluem: sulfeto, tiosulfato, hidroxilamina e ditionita. 
A equação (1) apresenta a reação do ferro III que é reduzido pela ditionita (Vermuel et al., 2000):

$$
\mathrm{S}_{2} \mathrm{O}_{4}^{-2}+2 \mathrm{Fe}^{+3}+2 \mathrm{H}_{2} \mathrm{O} \rightarrow 2 \mathrm{Fe}^{+2}+2\left(\mathrm{SO}_{3}^{-2}\right)+4 \mathrm{H}^{+}
$$

Na presença do ferro II, o composto solvente clorado TCE, pode ser abioticamente reduzido para cloro-acetato, como mostrado na equação (2) (Arnold e Roberts, 2000):

$$
\mathrm{Cl}_{2} \mathrm{C}=\mathrm{CClH}+2 \mathrm{Fe}^{+2} \rightarrow \mathrm{ClC} \equiv \mathrm{CH}+2 \mathrm{Fe}^{+3}
$$

De acordo com testes realizados por Vermuel et al. (2000), potenciais efeitos secundários associados à utilização da ditionita como agente redutor, incluem mobilização de metais, concentrações residuais, performance hidráulica e o consumo total do oxigênio dissolvido. Devido ao ambiente reduzido formado pela injeção da ditionita, metais ou hidróxidos estáveis podem reagir e compostos como arsênio e manganês serem mobilizados para o meio. Apesar disso, notou-se que os metais mobilizados, identificados em concentrações que ultrapassam os limites estabelecidos pelos órgãos ambientais, permaneceram concentrados na área de tratamento. Quanto aos compostos químicos residuais, o que pode apresentar alguma preocupação é o sulfato, por ser o primeiro produto de reação da injeção de ditionita. Observou-se uma pequena variação da permeabilidade apenas próximos aos poços de injeção, provavelmente devido a mineralização associada ao carbonato utilizado para controlar o pH e manter a estabilidade da ditionita, mas não resultou em diminuição na performance do tratamento.

Experimentos foram realizados com solo impactado por 1,1-DCA e 1,1-DCE, originados pela degradação do 1,1,1-TCA para avaliar os resultados da aplicação dos agentes redutores ditionita de sódio $\left(\mathrm{N}_{2} \mathrm{~S}_{2} \mathrm{O}_{4}\right)$ e polisulfeto de cálcio $\left(\mathrm{CaS}_{5}\right)$ e verificar a possibilidade de alteração nos resultados conforme o agente e os contaminantes. Os resultados mostraram que ambos os microcosmos tratados com os agentes redutores tiveram os compostos, 1,1-DA e 1,1-DCE, reduzidos. No entanto foram identificadas diferenças na reatividade entre os dois redutores. A ditionita de sódio foi mais efetiva no tratamento do 1,1-DCE, enquanto o polisulfeto de cálcio mostrou mais eficiência na redução do 1,1-DCA (Chemburkar et al., 2006).

O polisulfeto de cálcio é um fungicida/inseticida produzido a partir de cal $(\mathrm{CaO})$ e enxofre (S), como apresentado na fórmula (3):

$$
3 \mathrm{CaO}+11 \mathrm{~S} \rightarrow 2 \mathrm{CaS}_{5}+\mathrm{CaSO}_{3}
$$

O produto gerado a partir do cozimento do enxofre e cal gera tanto o polisulfeto de cálcio $\left(2 \mathrm{CaS}_{5}\right)$, quanto o sulfito de cálcio $\left(\mathrm{CaSO}_{3}\right)$, que segundo Brown et al. (2005b), 
contribuem na produção do ferro bivalente a partir da redução do ferro trivalente existente naturalmente no solo.

De acordo com as reações ocorridas nos testes realizados por Brown; et al. (2005b), uma vez injetado no aquífero, o polisulfeto de cálcio pode ter efeito no material geológico, proporcionando a redução do ferro trivalente $\left(\mathrm{Fe}^{3+}\right)$, presente sob a forma de óxidos e hidróxidos, para o ferro bivalente $\left(\mathrm{Fe}^{2+}\right)$. As equações deste agente redutor podem ser observadas pelas reações ocorridas em condições básicas (4) e neutras (5):

$$
\begin{aligned}
& 2 \mathrm{CaS}_{5}+16 \mathrm{OH}^{-}+16 \mathrm{Fe}^{+3} \rightarrow 2 \mathrm{CaSO}_{4}+\mathrm{S}_{8}{ }^{0}+8 \mathrm{H}_{2} \mathrm{O}+16 \mathrm{Fe}^{+2} \\
& 8 \mathrm{CaS}_{5}+16 \mathrm{Fe}^{+3} \rightarrow 8 \mathrm{Ca}^{+2}+5 \mathrm{~S}_{8}{ }^{0}+16 \mathrm{Fe}^{+2}
\end{aligned}
$$

O comportamento do ferro bivalente durante o processo de degradação elimina os cloretos da composição química dos compostos orgânicos clorados sem a acumulação de produtos da degradação seqüenciada (onde ocorre a eliminação de apenas um cloreto em cada sequência). A eliminação de dois cloretos da molécula de TCE diminuiria ou evitaria a formação do subproduto cloreto de vinila (mais tóxico que o produto solvente original), como ocorre na degradação por atenuação natural.

Assim, com a presença do agente redutor espera-se que o ferro bivalente produzido atue na degradação dos compostos orgânicos voláteis através da $\beta$-eliminação (eliminação de dois cloretos por vez). Esse ferro bivalente formado é somado ao ferro bivalente naturalmente presente na área e potencializa a capacidade redutiva do meio de forma a tornar mais propícia a degradação. A partir da redução do composto TCE para cloroacetileno, apresentado na equação (4), o cloroacetileno pode ser hidrolisado e formar acetato e íons cloreto (6), compostos inócuos ao meio ambiente:

$$
\mathrm{ClC} \equiv \mathrm{CH}+2 \mathrm{OH}^{-} \rightarrow \mathrm{CH}_{3} \mathrm{CO}_{2}^{-}+\mathrm{Cl}^{-}
$$

\subsubsection{OXIDAÇÃO QUÍMICA IN SITU}

A oxidação química deve ser predominantemente utilizada como alternativa de remediação, quando os contaminantes organoclorados estão presentes no solo saturado ou franja capilar, nas fases dissolvida e adsorvida. Em locais onde é necessário o tratamento de área fonte na zona não saturada, o mais indicado é que outra tecnologia de remediação seja requerida, como por exemplo, a extração de vapores do solo. Na existência de produto em fase livre, outras tecnologias de remediação precisam ser conduzidas anteriormente à oxidação química para que a remediação seja segura e o custo viável (USEPA, 2008).

Aplicações adequadas da oxidação química implicam em resultados mais rápidos e de custos mais atrativos na reabilitação de uma área contaminada por compostos 
organoclorados, do que alternativas que envolvam bombeamento e tratamento da água contaminada, ou mesmo a atenuação natural. Diversos oxidantes podem ser utilizados nesta alternativa de remediação, os principais são: 1) permanganato de potássio; 2) permanganato de sódio $\left(\mathrm{NaMnO}_{4}\right)$; 3) peróxido de hidrogênio $\left(\mathrm{H}_{2} \mathrm{O}_{2}\right)$; 4) persulfato $\left(\mathrm{S}_{2} \mathrm{O}_{8}\right)$; e 5) ozônio $\left(\mathrm{O}_{3}\right)$.

$\mathrm{O} \mathrm{KMnO}_{4}$ é um sal cristalino fino que pode ser dissolvido em campo, criando soluções de concentração de até $6 \%$, em temperatura ambiente de $20^{\circ} \mathrm{C}$. Em temperaturas inferiores, a solubilidade deste oxidante pode diminuir consideravelmente (Suthersan e Payne, 2005).

Devido à baixa reatividade entre o permanganato de potássio e a matriz do aquífero durante as reações de oxidação química, este oxidante pode ser transportado pelos processos advectivo e dispersivo juntamente com o fluxo da água subterrânea e persistir por um período maior de tempo, em relação ao peróxido de hidrogênio e o ozônio, reagindo com os contaminantes orgânicos. Além disso, a presença do $\mathrm{KMnO}_{4}$ no aquífero não produz calor ou gases (Marvin, Chambers e Leavitt, 2002).

As reações entre o $\mathrm{KMnO}_{4}$ e os solventes organoclorados, PCE, TCE, DCE e VC, são apresentadas, respectivamente, pelas equações (7) a (10), conforme Crimi e Siegrist (2003):

$$
\begin{aligned}
& 4 \mathrm{KMnO}_{4}+3 \mathrm{C}_{2} \mathrm{Cl}_{4}+4 \mathrm{H}_{2} \mathrm{O} \rightarrow 6 \mathrm{CO}_{2}+4 \mathrm{MnO}_{2}+4 \mathrm{~K}^{+}+8 \mathrm{H}^{+}+12 \mathrm{Cl}^{-} \\
& 2 \mathrm{KMnO}_{4}+\mathrm{C}_{2} \mathrm{HCl}_{3} \rightarrow 2 \mathrm{CO}_{2}+2 \mathrm{MnO}_{2}+2 \mathrm{~K}^{+}+\mathrm{H}^{+}+3 \mathrm{Cl}^{-} \\
& 8 \mathrm{KMnO}_{4}+3 \mathrm{C}_{2} \mathrm{H}_{2} \mathrm{Cl}_{2} \rightarrow 6 \mathrm{CO}_{2}+8 \mathrm{MnO}_{2}+8 \mathrm{~K}^{+}+6 \mathrm{Cl}^{-}+2 \mathrm{OH}^{-}+2 \mathrm{H}_{2} \mathrm{O} \\
& 10 \mathrm{KMnO}_{4}+3 \mathrm{C}_{2} \mathrm{H}_{3} \mathrm{Cl} \rightarrow 6 \mathrm{CO}_{2}+10 \mathrm{MnO}_{2}+10 \mathrm{~K}^{+}+3 \mathrm{Cl}^{-}+7 \mathrm{OH}^{-}+\mathrm{H}_{2} \mathrm{O} \\
& \mathrm{O} \text { ingrediente ativo na oxidação do permanganato de potássio é o íon }
\end{aligned}
$$

permanganato $\left(\mathrm{MnO}_{4}{ }^{-}\right)$. $\mathrm{O}$ átomo de manganês possui valência +7 e é apresentado como $\mathrm{Mn}(\mathrm{VII})$. Durante o processo de oxidação, o manganês é reduzido para valência +4 e é apresentado como $\mathrm{Mn}(\mathrm{IV})$. O principal produto da reação com o contaminante é o dióxido de manganês, que precipita da solução (Suthersan e Payne, 2005).

O permanganato tem grande afinidade na oxidação de compostos contendo cadeias de carbono com ligação dupla, grupos dos aldeídos e das hidroxilas. Sob condições normais de $\mathrm{pH}$ e temperatura, a ligação dupla das cadeias de carbono dos alcenos é quebrada espontaneamente e compostos intermediários instáveis são convertidos em dióxido de carbono (Hu e Chou, 2002). Além de dióxido de carbono, são também resultados da reação: sólidos de dióxido de manganês e íons de potássio e manganês (quando compostos halogenados são oxidados). Mas na quantidade gerada, estes compostos, não 
são tóxicos à saúde humana (DOE, 1999).

Segundo Marvin, Chambers e Leavitt (2002), a taxa de reação de um organoclorado com o $\mathrm{KMnO}_{4}$ na fase dissolvida é dependente das concentrações de ambos os compostos. $\mathrm{O}$ aumento da dosagem do $\mathrm{KMnO}_{4}$ aumentará não somente a oxidação do contaminante, mas também o consumo do permanganato. Mas a diminuição na concentração do $\mathrm{KMnO}_{4}$ poderá diminuir a cinética das reações, causando a coexistência entre o contaminante e o agente oxidante, o que diminuiria a efetividade da oxidação química.

A avaliação correta da dosagem de $\mathrm{KMnO}_{4}$ é o primeiro passo para a escolha desta alternativa como tratamento de um meio contaminado por compostos organoclorados e é obtida pela demanda de oxidante no solo (Soil Oxidant Demand - SOD) ou demanda natural de oxidante (Natural Oxidant Demand - NOD). O SOD ou NOD é a quantidade de oxidante consumido por unidade de massa sólida do aquífero em determinado tempo. A eficácia da oxidação de contaminantes organoclorados até sua completa mineralização é inversamente proporcional à presença natural de matéria orgânica, ferro ferroso $\left(\mathrm{Fe}^{+2}\right)$ ou outros metais reduzidos no solo. Isto porque, durante o processo de oxidação, não há diferenciação do permanganato de potássio entre compostos orgânicos e inorgânicos oxidáveis naturalmente presentes no solo dos contaminantes (Hønning, 2007).

Em muitos casos, o $\mathrm{KMnO}_{4}$ necessário para a remediação in situ da água subterrânea é controlado mais pelo SOD do que pelas concentrações dos contaminantes presentes. Em geral, solo de granulometria fina com alta porcentagem de carbono orgânico exibe um alto SOD em comparação com a areia grossa (Marvin, Chambers e Leavitt, 2002). Valor muito elevado de SOD pode tornar a alternativa inviável, por implicar numa grande quantidade de permanganato a ser utilizado, já que este oxidará não somente os contaminantes orgânicos, mas também o carbono orgânico e metais reduzidos presente no meio.

Resumidamente, o conhecimento de fatores específicos da área de interesse, fundamental para a seleção desta tecnologia de remediação, envolve: 1) tipo e distribuição dos compostos contaminantes; 2) litologia; 3) SOD; e 4) geoquímica do meio físico. A combinação destas informações e de resultados obtidos por testes em laboratório (para avaliar a eficiência do agente químico de interesse em abater concentrações de contaminantes na água subterrânea) e testes piloto em campo, podem fornecer informações quanto aos efeitos secundários como diminuição da permeabilidade, mobilização e atenuação de metais redox-sensíveis e o potencial reaparecimento dos contaminantes após o tratamento (Marvin, Chambers e Leavitt, 2002).

Devido ao permanganato de potássio sólido ser derivado da extração de minérios, pode haver impurezas em seus cristais comercialmente disponíveis, que incluem sais e 
traços de metais. Embora a composição deste produto seja irrelevante à reação de oxidação dos contaminantes, pode ser potencialmente relevante em subsuperfície, quando comparada aos padrões e critérios de qualidade da água subterrânea (Crimi e Siegrist, 2003). A Tabela 4 apresenta os metais identificados pela análise química de uma amostra de permanganato de potássio realizada na matriz sólida do oxidante e na solução preparada a $0,5 \%$ (ERM, 2009). A qualidade deste produto pode ser considerada não satisfatória para ser utilizada como agente remediador, por apresentar concentrações de metais, que quando inseridos na água subterrânea poderiam ocasionar em valores não aceitáveis de acordo com os padrões ambientais.

Tabela 4 - Exemplo de concentrações de metais identificadas em amostra de permanganato de potássio considerada não ideal para remediação de área contaminada

\begin{tabular}{cccc}
\hline Elemento & $\begin{array}{c}\text { Concentração na } \\
\text { matriz sólida } \\
(\mathbf{m g} / \mathbf{k g})\end{array}$ & $\begin{array}{c}\text { Concentração na } \\
\text { solução à 5\% } \\
\mathbf{( m g / L )}\end{array}$ & $\begin{array}{c}\text { Valor de referência } \\
\text { CETESB* } \\
(\mathbf{m g} / \mathbf{L})\end{array}$ \\
\hline Antimônio & 0,37 & 0,016 & 0,005 \\
Bário & 5,95 & $<0,100$ & 0,700 \\
Chumbo & 28,70 & 0,018 & 0,010 \\
Ferro & 48,00 & $<0,300$ & 0,300 \\
Zinco & 11,60 & 0,184 & 5,000 \\
\hline
\end{tabular}

(*) Companhia Ambiental do Estado de São Paulo

Assim, embora sua eficácia em reduzir as concentrações de contaminantes organoclorados presentes em subsuperfície seja elevada, a procedência e a composição do permanganato de potássio, assim como de outros agentes, devem ser avaliadas cuidadosamente.

\section{MATERIAIS E MÉTODOS}

Serão apresentadas neste item, as atividades realizadas nas áreas de estudo que são de importância para o desenvolvimento adequado de um sistema de remediação. É importante lembrar que as áreas estão em diferentes posições quanto ao processo de reabilitação. Como a Área 2 encontra-se mais adiantada nesta atividade, será descrita toda a sequência de tarefas realizadas até a implantação do sistema de remediação em toda a área impactada através da ISCO. Enquanto na Área 1 serão apresentadas as atividades realizadas até a implantação do teste piloto da ISCR. 


\subsection{APLICAÇÃo dA TÉCNICA dE REDUÇÃo QUÍMICA IN SITU}

Os ensaios realizados e descritos a seguir foram conduzidos com o objetivo de trazer respostas quanto ao comportamento hidráulico do aquífero frente à injeção de fluido e às características da contaminação do meio em que estão inseridas. Respostas tais que são fundamentais para a seleção de uma metodologia de remediação e, portanto, devem ser avaliadas.

\subsubsection{Ensaios em Campo e em laboratório}

\section{Teste de injeção de água}

Para a condução do teste, foram instalados primeiramente dois poços de injeção no centro da pluma de VOCs, onde as concentrações de contaminantes organoclorados são maiores. O objetivo deste teste foi avaliar o comportamento hidráulico do aquífero freático frente à injeção de fluidos.

Para os testes de injeção de água, foram instalados quatro poços de injeção, identificados como RW-01 ao RW-04. A metodologia de instalação destes poços é semelhante à dos poços de monitoramento, encontrada na Norma Brasileira NBR 1595-1 (ABNT, 2007), com exceção da seção filtrante ser totalmente penetrante no manto de intemperismo e o selo ser composto por calda de cimento (95\%) e bentonita (5\%). A profundidade final destes poços de injeção permaneceu em cerca de $20 \mathrm{~m}$.

Os testes em cada um dos poços de injeção foram conduzidos pelo período de seis horas de carga contínua, a partir de um reservatório de $2.000 \mathrm{~L}$ de água provida do abastecimento público. Para avaliar possíveis interferências na hidráulica do aquífero, os níveis d'água de poços de monitoramento próximos foram medidos antes dos testes, três e seis horas após o início da injeção.

\section{Análises laboratoriais para avaliar teor de ferro no solo e eficiência de potenciais redutores}

Com os resultados do teste de injeção de água mostrando que o aquífero poderia receber alternativas de remediação que envolvessem a injeção de fluidos partiu-se para análises específicas do meio e estudos de tratabilidade para avaliar a potencial redução dos contaminantes presentes na água subterrânea. Assim, a metodologia de remediação por redução química in situ surgiu como uma possível alternativa para a reabilitação da Área 1. Inicialmente, amostras de solo saturado foram obtidas durante a instalação de dois poços de injeção (RW-03 e RW-04). Três amostras foram coletadas em cada uma das perfurações nas profundidades de 12, 15 e $18 \mathrm{~m}$ e enviadas ao laboratório para análises químicas de ferro trivalente. 
Devido às condições altamente oxidantes do procedimento no laboratório para a avaliação do teor de ferro III, não foi possível a obtenção das concentrações de ferro II nestas análises, portanto, novas amostras de solo saturado foram coletadas em três pontos na área mais impactada da pluma de VOC para avaliação também das concentrações de ferro II presente naturalmente no aquífero.

Como as concentrações de ferro presente no aquífero foram consideradas satisfatórias para a aplicação da ISCR como metodologia de remediação, testes de tratabilidade foram realizados. O primeiro teste em laboratório envolveu o tratamento do solo saturado contaminado, por um período de 20 dias com quatro agentes redutores para avaliar a capacidade de cada um em reduzir o ferro III, presente naturalmente na área, em ferro II.

Os redutores utilizados no teste foram:

1) Sulfeto de sódio $\left(\mathrm{Na}_{2} \mathrm{~S}\right)$ - agente redutor industrial utilizado na fabricação de papel e no tratamento de metais. Reduz o ferro e provoca a precipitação de pirita, mineral declorador conhecido;

2) Polisulfeto de cáclio $\left(\mathrm{CaS}_{5}\right)$ - também conhecido como lime sulfur, substância agrícola, utilizada também para redução de cromo;

3) Ditionita de sódio $\left(\mathrm{Na}_{2} \mathrm{~S}_{2} \mathrm{O}_{4}\right)$ - agente redutor muito forte, utilizado tanto na redução de cromo, quanto para aumentar a eficácia de reações de decloração redutiva; e

4) Oxalato de sódio $\left(\mathrm{Na}_{2} \mathrm{C}_{2} \mathrm{O}_{4}\right)$ - composto utilizado no acabamento de metais para remoção de ferrugem e para descoloração de madeira e couro.

Foram realizados testes considerando adição de carbonato de sódio para tamponamento do $\mathrm{pH}$ e sem adição do carbonato de sódio.

Os dois redutores que apresentaram os melhores resultados foram utilizados em um novo teste de tratablilidade, onde foi observado, a redução dos contaminantes organoclorados presentes no meio e consequentemente a diminuição de suas concentrações. Este segundo teste de tratabilidade foi realizado pelo período de 117 dias.

Como os resultados obtidos indicaram a ISCR como metodologia de remediação aplicável na área, partiu-se para a implementação do teste piloto, visando a reabilitação da área impactada por VOCs.

\subsubsection{INJEÇÃo do Redutor Em Escala do Teste Piloto}

A partir dos resultados dos testes de injeção de água, dois poços (RW-02 e RW-04) foram selecionados para injeção do agente redutor como teste piloto por terem apresentado as melhores respostas. 


\section{Instalação de poços de monitoramento}

Para a realização do teste piloto foram instalados seis poços de monitoramento, sendo três (MW-301 ao MW-303) a jusante do poço de injeção RW-02 e três (MW-304 ao MW-306) a jusante do RW-04. A alocação dos poços de monitoramento e a relação entre as distâncias dos poços utilizados para a injeção do produto foi realizada em função de testes de injeção de água que estimaram o raio de influência ao redor da área através da variação do nível d'água nos poços mais próximos. A localização dos poços de injeção e dos poços de monitoramento instalados nesse trabalho pode ser observada em detalhe na Figura 13.

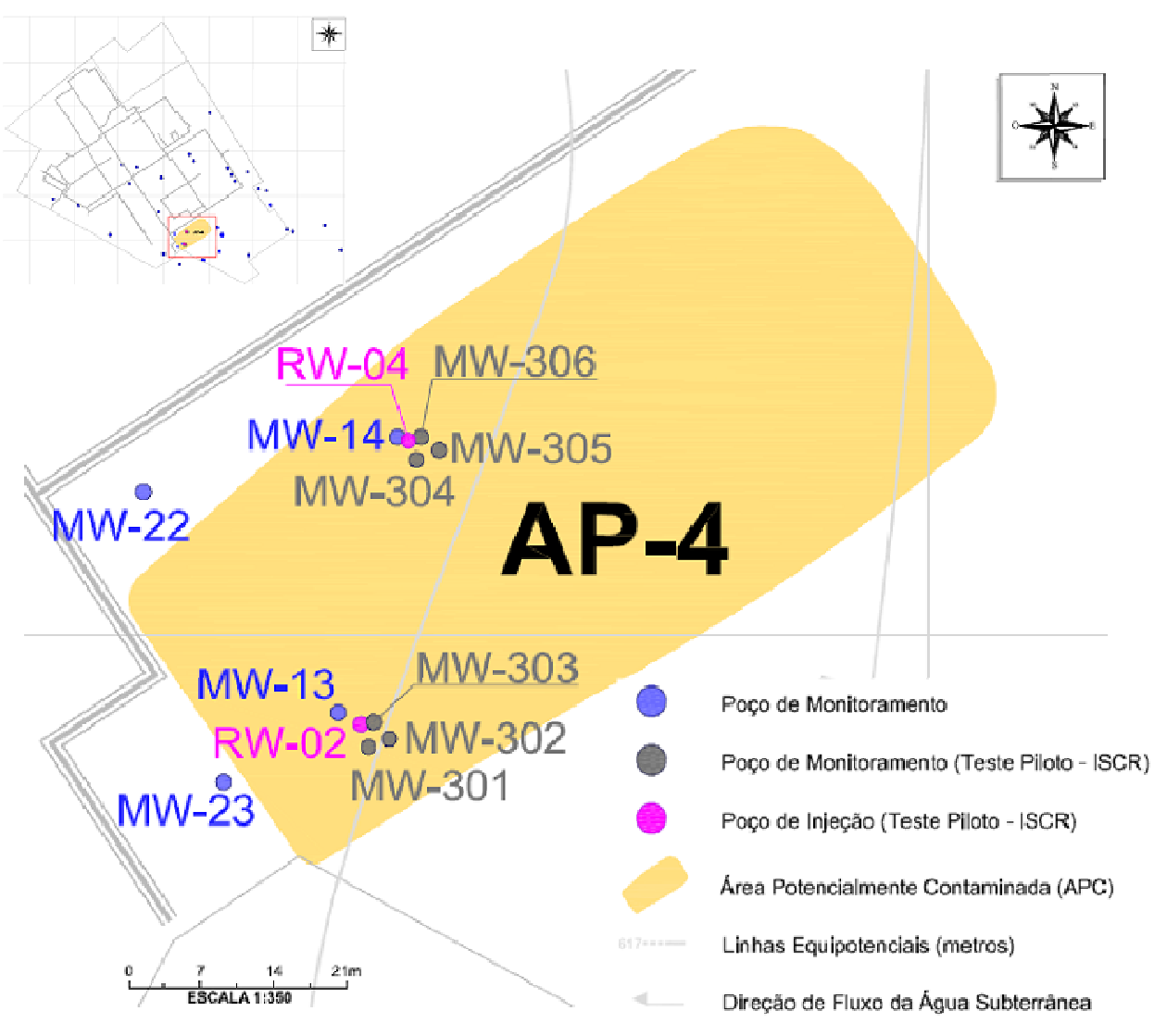

Figura 13 - Detalhe da área do teste piloto de ISCR

Os poços de monitoramento foram instalados com tubulação de PVC geo-mecânico de duas polegadas de diâmetro, profundidade máxima de $17 \mathrm{~m}$ e seção filtrante de $3 \mathrm{~m}$ nas unidades do manto de intemperismo, iniciando-se $1 \mathrm{~m}$ abaixo da identificação do nível d'água durante a instalação.

Os perfis construtivos dos poços de monitoramento existentes e instalados para o teste piloto, bem como os poços de injeção utilizados no teste são apresentados no Anexo 1 desde relatório. 


\section{Caracterização inicial}

A caracterização inicial foi realizada antes do início da injeção e envolveu uma campanha de monitoramento da água subterrânea, medições de parâmetros físico-químicos em campo e análises químicas em laboratório. Os resultados desta caracterização forneceram informações de base para comparar o comportamento do meio antes e após a presença do agente redutor selecionado.

A amostragem envolveu a coleta e análise da água subterrânea dos poços de injeção (RW-02 e RW-04), dos poços de monitoramento a montante (MW-13, MW-14, MW22 e MW-23) e a jusante (MW-301 ao MW-306). A coleta das amostras foi realizada pelo método de baixa vazão, que minimiza a agitação e a exposição da água subterrânea ao ar ambiente. A seleção de poços de monitoramento a montante da área do teste piloto foi importante porque forneceu informações sobre o comportamento dos contaminantes no aquífero que não entraram em contato com o redutor, ou seja, foi possível avaliar se alterações nas concentrações dos poços de monitoramento a jusante, foi resultado da presença do agente redutor ou de variações ocorridas naturalmente na área.

Foram considerados os seguintes parâmetros medidos em campo: $\mathrm{pH}$, potencial de oxi-redução (ORP) e condutividade elétrica. Os parâmetros para serem analisados em laboratório compreenderam: VOC, ferro dissolvido, sulfato, alcalinidade e RedEq. O parâmetro RedEq, determinado pela titulação da água subterrânea coletada com permanganato de potássio $\left(\mathrm{KMnO}_{4}\right)$, teve como objetivo quantificar quão redutor o meio se apresentava. Também foram coletadas amostras de controle de qualidade como: duplicata, branco de equipamento e branco de campo.

A Tabela 5 apresenta um resumo do plano de amostragem da caracterização inicial. 
Tabela 5 - Plano de amostragem da caracterização inicial

\begin{tabular}{|c|c|c|c|c|}
\hline \multicolumn{2}{|c|}{$\begin{array}{c}\text { Poço } \\
\text { (Localização) }\end{array}$} & $\begin{array}{c}\text { Metodologia de } \\
\text { amostragem }\end{array}$ & $\begin{array}{l}\text { Parâmetros medidos em } \\
\text { campo }\end{array}$ & \multirow[t]{2}{*}{$\begin{array}{c}\text { Parâmetros analisados em } \\
\text { laboratório }\end{array}$} \\
\hline \multicolumn{4}{|c|}{ Poços de montante mais distante } & \\
\hline $\begin{array}{l}M W-22 \\
M W-23\end{array}$ & $\begin{array}{l}\text { Montante } \\
\text { Montante }\end{array}$ & Baixa vazão & $\begin{array}{c}\mathrm{pH}, \mathrm{ORP}, \text { condutividade } \\
\text { elétrica }\end{array}$ & $\begin{array}{l}\text { VOC, ferro dissolvido, sulfato, } \\
\text { alcalinidade, RedEq }\end{array}$ \\
\hline \multicolumn{5}{|c|}{ Conjunto RW-02 } \\
\hline MW-13 & Montante & & \multirow{3}{*}{$\begin{array}{c}\mathrm{pH}, \mathrm{ORP}, \text { condutividade } \\
\text { elétrica }\end{array}$} & \multirow{3}{*}{$\begin{array}{l}\text { VOC, ferro dissolvido, sulfato, } \\
\text { alcalinidade, RedEq }\end{array}$} \\
\hline $\begin{array}{l}\text { RW-02 } \\
\text { MW-301 } \\
\text { MW-302 }\end{array}$ & $\begin{array}{l}\text { Injeção } \\
\text { Jusante } \\
\text { Jusante }\end{array}$ & Baixa vazão & & \\
\hline MW-303 & Jusante & & & \\
\hline \multicolumn{5}{|c|}{ Conjunto RW-04 } \\
\hline MW-14 & Montante & & \multirow{3}{*}{$\begin{array}{c}\mathrm{pH}, \mathrm{ORP}, \text { condutividade } \\
\text { elétrica }\end{array}$} & \multirow{3}{*}{$\begin{array}{l}\text { VOC ferro dissolvido, sulfato, } \\
\text { alcalinidade, RedEq }\end{array}$} \\
\hline $\begin{array}{c}\text { RW-04 } \\
\text { MW-304 } \\
\text { MW-305 }\end{array}$ & $\begin{array}{l}\text { Injeção } \\
\text { Jusante } \\
\text { Jusante }\end{array}$ & Baixa vazão & & \\
\hline MW-306 & Jusante & & & \\
\hline \multicolumn{5}{|c|}{ Amostras de Controle de Qualidade } \\
\hline \multicolumn{2}{|c|}{$\begin{array}{c}\text { Branco de equipamento } \\
\text { Duplicata } \\
\text { Branco de campo }\end{array}$} & Baixa vazão & $\begin{array}{c}\mathrm{pH}, \mathrm{ORP}, \text { condutividade } \\
\text { elétrica }\end{array}$ & $\begin{array}{c}\text { VOC, ferro dissolvido, sulfato, } \\
\text { alcalinidade, RedEq } \\
\text { VOC, RedEq }\end{array}$ \\
\hline
\end{tabular}

\section{Preparação e injeção do agente redutor}

Idealmente a preparação da mistura deveria ser realizada apenas com a água subterrânea impactada extraída dos poços de monitoramento através de bombeamento, para que as propriedades físico-químicas do meio fossem preservadas (presença de ferro III) e auxiliassem na redução dos compostos organoclorados presentes. Mas devido às propriedades hidráulicas do aquífero, o bombeamento do volume ideal para a confecção da mistura não foi possível, dessa forma, a mistura foi completada com água de abastecimento público local.

O produto selecionado e utilizado no teste piloto, o polisulfeto de cálcio $\left(\mathrm{CaS}_{5}\right)$, foi obtido no mercado nacional. O produto, formado pela fervura do enxofre natural (18\%) e cal hidratada (6\%), é normalmente utilizado como fertilizante foliar líquido. Possui densidade de $1,25 \mathrm{~g} / \mathrm{cm}^{3}$.

A água bombeada foi inicialmente dirigida a um tanque com volume de $2.000 \mathrm{~L}$ para ser misturada ao agente redutor. A mistura pronta foi encaminhada ao tanque com capacidade de $10.000 \mathrm{~L}$ para posteriormente ser injetada. A cada $2.000 \mathrm{~L}$ de mistura preparada e transferida para o tanque de injeção, os parâmetros $\mathrm{pH}$, ORP e condutividade 
elétrica foram medidos.

Após a solução completa no tanque de injeção, uma nova medição dos parâmetros físico-químicos ( $\mathrm{pH}$, ORP e condutividade elétrica) e coleta de amostra para análise laboratorial de VOC foram realizadas. Esta mesma sequência de operação foi realizada para ambas as áreas de injeção (RW-02 e RW-04). A Tabela 6 apresenta os parâmetros medidos durante o processo de mistura.

Tabela 6 - Plano de amostragem do processo de mistura

\begin{tabular}{|c|c|c|c|c|}
\hline \multirow[b]{2}{*}{ Tanque } & \multicolumn{4}{|c|}{ Medição dos parâmetros durante o processo de mistura } \\
\hline & $\begin{array}{l}2000 \text { L (água } \\
\text { subterrânea) }\end{array}$ & $\begin{array}{l}4000 \text { L (água } \\
\text { subterrânea) }\end{array}$ & $\begin{array}{l}6000 \text { L (água } \\
\text { subterrânea) }\end{array}$ & $\begin{array}{c}10000 \text { L (solução- } \\
\text { água/produto) }\end{array}$ \\
\hline Tanque 1 (RW-02) & \multicolumn{4}{|c|}{$\mathrm{pH}, \mathrm{ORP}$, condutividade elétrica durante o bombeamento e VOC após a solução } \\
\hline Tanque 2 (RW-04) & \multicolumn{4}{|c|}{ completa } \\
\hline
\end{tabular}

Após a preparação da mistura ter sido completada, foi iniciado o processo de injeção contínua por gravidade para cada poço com vazão média de $1.000 \mathrm{~L} / \mathrm{h}$ para ambas as áreas.

\section{Monitoramento Inicial}

Após a injeção, os poços selecionados foram monitorados para avaliar o comportamento dos parâmetros físico-químicos da água subterrânea ao longo de sete dias, como apresentado na Tabela 7. 
Tabela 7 - Plano de amostragem do monitoramento inicial

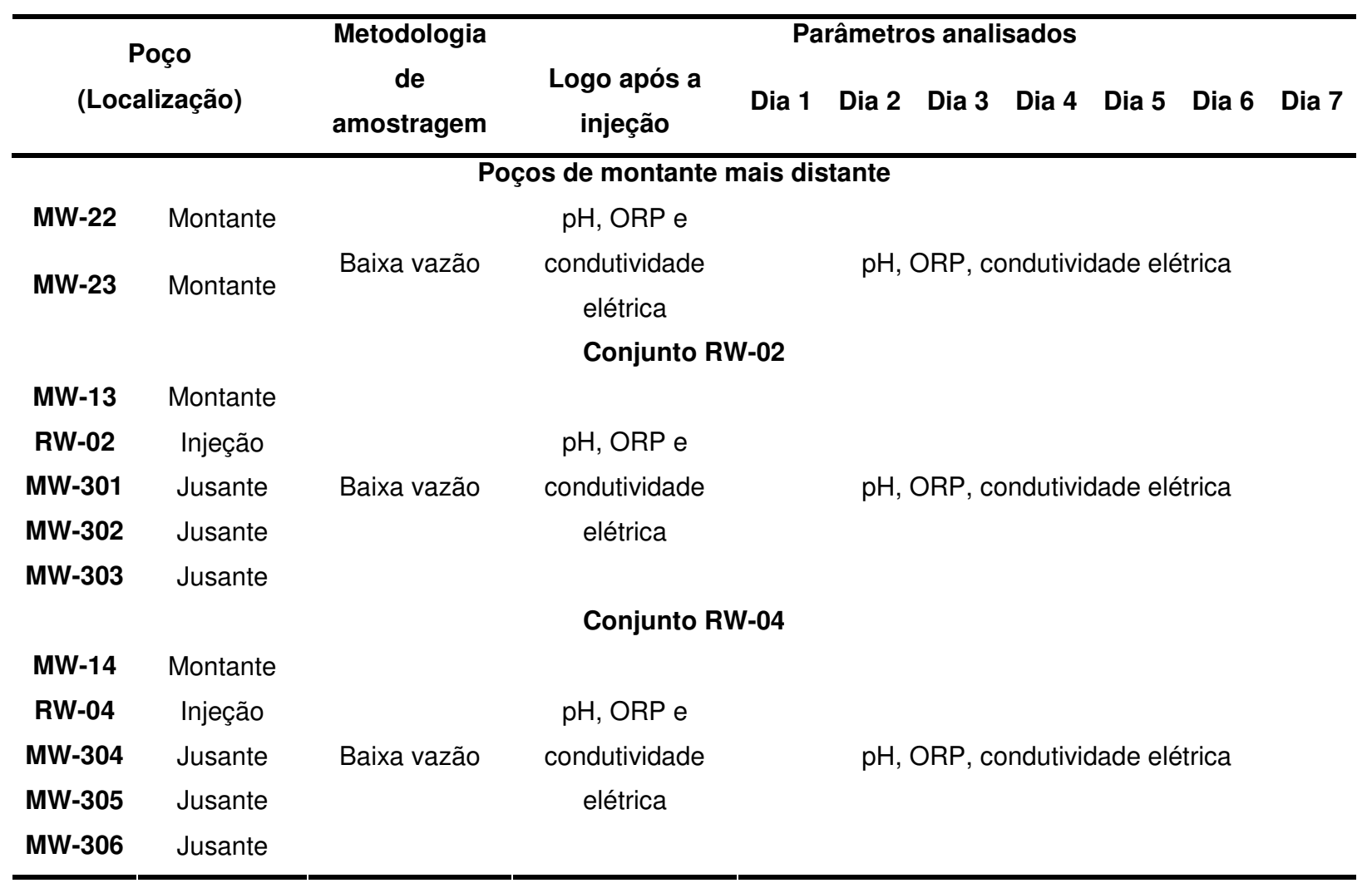

\section{Monitoramento de desempenho}

O monitoramento de desempenho do teste piloto foi realizado com amostragem da água subterrânea após a injeção nos períodos de: um, três, seis e onze meses. Assim como nas demais campanhas, o método utilizado para a coleta foi o de baixa vazão.

Embora inicialmente fazendo parte do plano de amostragem, as análises de ferro bivalente dissolvido, sulfato e alcalinidade não foram realizadas no terceiro mês após a injeção. Como medida de controle de qualidade, foram coletadas amostras duplicatas, brancos de equipamento e brancos de campo durante as campanhas de monitoramento.

A Tabela 8 resume os parâmetros analisados ao longo do monitoramento de desempenho. 
Tabela 8 - Plano de amostragem do monitoramento de desempenho

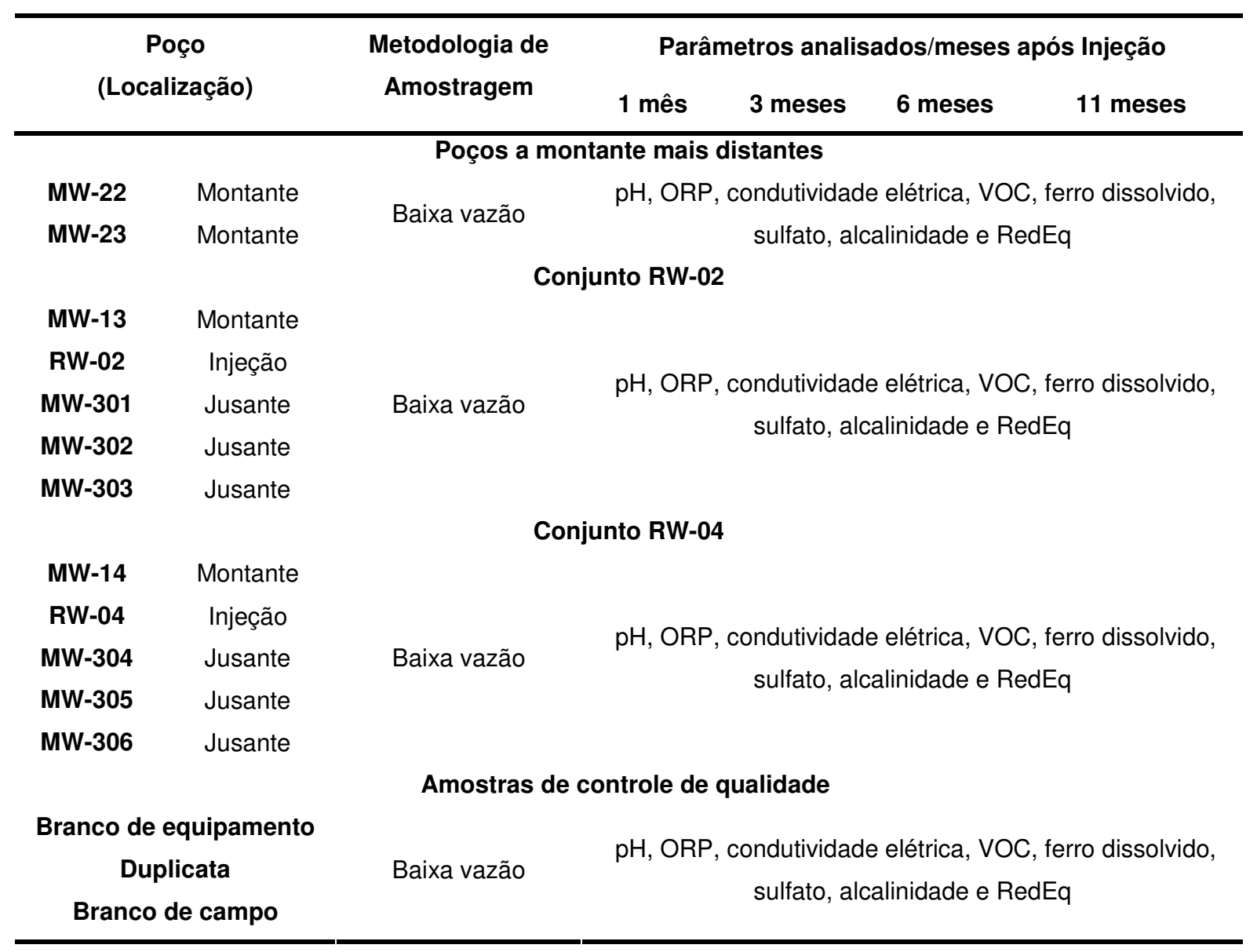

\subsection{APLICAÇÃo da TÉCNICA dE OXIDAÇÃo QUÍMICA IN SITU}

Como todo processo que envolve a implantação de uma metodologia de remediação, foi necessário a condução de atividades prévias em campo e em laboratório para embasar a utilização da oxidação química como meio de promover a reabilitação da segunda área de estudo.

A seguir serão apresentadas as atividades realizadas para que a ISCO pudesse ser aplicada em toda a área contaminada.

\subsubsection{Ensaios em CAMpo e em Laboratório}

\section{Teste de injeção de água}

Um teste de injeção de água foi realizado com o objetivo de avaliar a efetividade hidráulica do aquífero freático em transportar o reagente de forma apropriada no seu interior. Para conduzir o teste, foram instalados dois poços de injeção a jusante da pluma existente a nordeste da área, originada pela manipulação inadequada de solventes clorados em local onde eram realizadas lavagens de automóveis. Estes poços de injeção foram instalados de 
forma semelhante aos existentes na Área 1, conforme descrição apresentada no item 5.1.1. A profundidade final de ambos os poços foi de $15 \mathrm{~m}$, nível onde foi localizado o topo da camada do aquitarde (siltito).

Devido às características da contaminação, dos contaminantes e a consideração de que a camada de siltito, existente na área de forma mais contínua e espessa do que observado na Área 1, agiu como uma barreira física do caminhamento do contaminante para níveis mais profundos, os poços de injeção foram instalados com seção filtrante totalmente penetrante na camada de manto de intemperismo. Isto facilitaria o contato do oxidante com o contaminante em todo nível saturado onde a contaminação foi identificada. A Figura 14 apresenta o perfil construtivo esquemático dos poços de injeção instalados na Área 2.

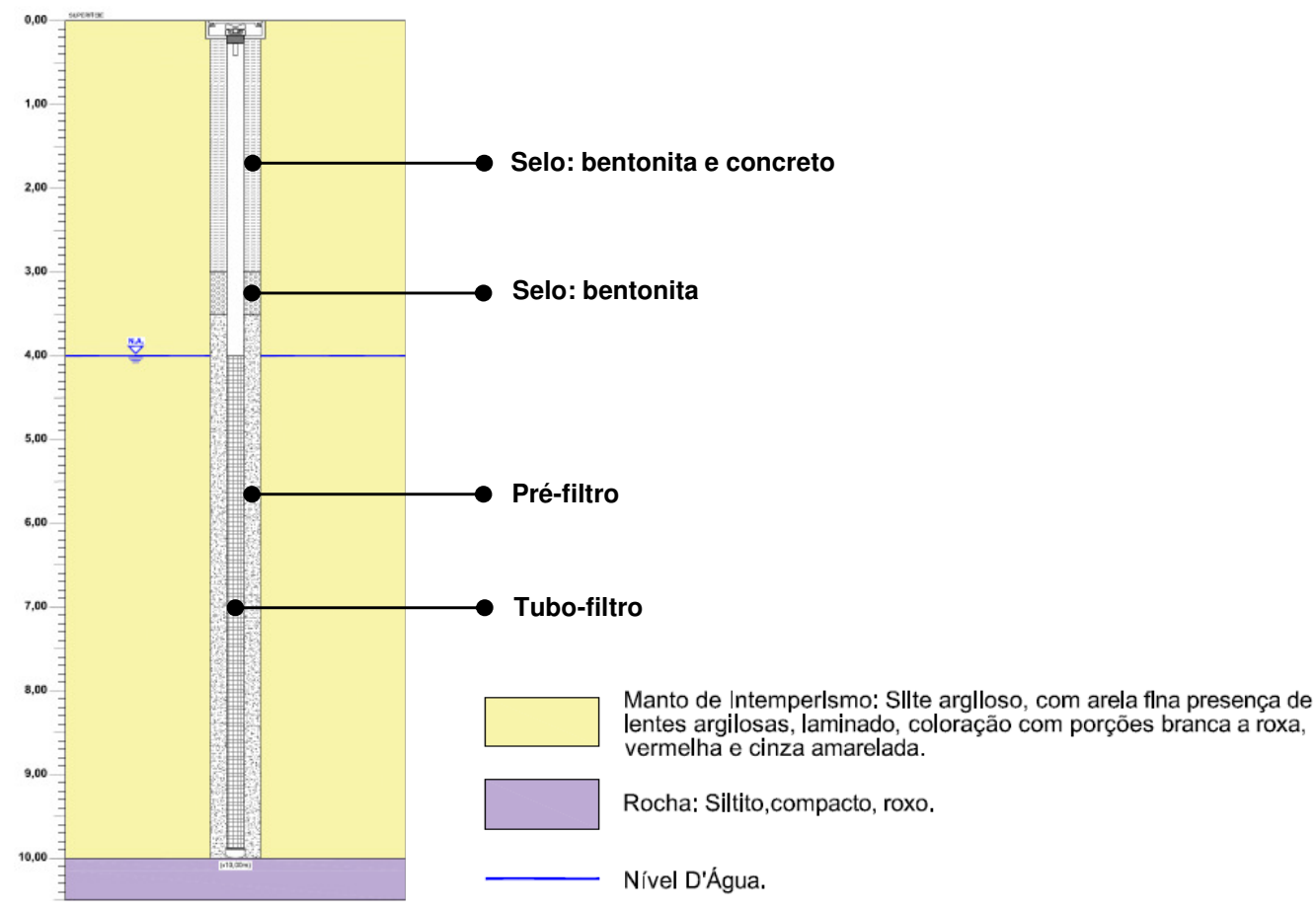

Figura 14 - Perfil esquemático de um poço de injeção

O teste de injeção em cada um dos poços de injeção consistiu na infiltração de água captada do abastecimento público da região pelo período de 6 horas contínuas com carga constante, para isso foi utilizado um reservatório de água de $2.000 \mathrm{~L}$. Para se evitar interferências na resposta do aquífero frente à injeção de água, os testes foram realizados em datas distintas, somente após a verificação do retorno do nível d'água estático identificado antes do início dos testes. Em cada um dos testes de injeção, onze poços de monitoramento existentes até $57 \mathrm{~m}$ de distância foram monitorados para avaliar a variação do nível d'água durante as 6 horas de injeção. Os resultados deste teste permitiriam avaliar o potencial raio de influência inicial do líquido injetado. 


\section{Análises laboratoriais para avaliar características específicas do solo e} eficiência do oxidante

A importância da avaliação de características específicas do aquífero é fundamental para identificar a potencialidade de aplicação de determinada alternativa de remediação. Assim, para avaliar a ISCO como metodologia de tratamento da área impactada por 1,1-DCE, foram coletadas amostras de solo saturado em três pontos distribuídos no centro da pluma deste contaminante, onde haviam sido identificadas as maiores concentrações. De cada ponto foram selecionadas três amostras entre 7 e $12 \mathrm{~m}$ de profundidade e enviadas ao laboratório para análises químicas de ferro total, carbono orgânico total e SOD. Os resultados destas análises apontam para a possibilidade ou não de remediação da área através da oxidação química, visto que altos teores de materiais potencialmente oxidáveis no solo competem com os contaminantes em relação às reações com o agente oxidante. Para a análise de SOD, as amostras das diferentes profundidades de cada ponto foram homogeneizadas e tituladas com $\mathrm{KMNO}_{4}$.

Para avaliar a eficiência do permanganato de potássio em oxidar os contaminantes, foram coletadas amostras de solo saturado para a realização de teste de tratabilidade em laboratório. Este teste, conhecido também como ensaio de bancada, apresenta como resultado, a degradação ou não dos contaminantes presentes no meio até as concentrações alcançarem níveis aceitáveis.

\subsubsection{InJeÇÃo do OXIDANTE Em Escala de Teste Piloto}

Embora os resultados dos testes em laboratório com o solo contaminado local tenham evidenciado a eficiência do permanganato em oxidar os contaminantes, o passo de testá-lo em uma pequena área da pluma deve ser respeitado, visto que os resultados em campo podem não refletir o observado em laboratório e haver a necessidade da avaliação de outras formas de remediação.

É importante que a área selecionada para o teste piloto represente as características do meio e contaminação como um todo. As técnicas aplicadas no teste piloto devem ser semelhantes à que potencialmente seriam empregadas, posteriormente em toda a área.

O local que apresentava as maiores concentrações de 1,1-DCE foi selecionado para a aplicação da ISCO como teste piloto (centro da pluma de contaminação a nordeste da área). Com base no raio de influência inicial identificado a partir dos resultados do teste de injeção de água, foram instalados sete poços de injeção de perfil construtivo semelhante ao apresentado na Figura 14, mas com profundidades variando entre 18 e 20 m, conforme identificação topo da camada de aquitarde. 
Para dimensionar a área impactada que seria primeiramente tratada neste teste piloto e avaliar os custos envolvidos, foi necessário verificar características específicas da área de estudo. Desta forma, com base nas informações levantadas em testes e análises anteriores, foram obtidos: o volume de solo saturado impactado (equação 11); o coeficiente de distribuição do contaminante (equação 12); a concentração média adsorvida no solo (equação 13); a massa de contaminante adsorvida na matriz sólida do aquífero (equação 14); o volume efetivo de solo contaminado que entrará em contato com o oxidante por poço de injeção (equação 15); a massa de oxidante necessária para tratamento da área do teste piloto (equação 16); e a concentração do oxidante utilizado na solução (equação 17).

$$
\begin{aligned}
& \mathrm{V}=\mathrm{A} \cdot \mathrm{h} \\
& \mathrm{K}_{\mathrm{d}}=\mathrm{K}_{\mathrm{oc}} \cdot \mathrm{f}_{\mathrm{oc}} \\
& \mathrm{C}_{\mathrm{s}}=\mathrm{K}_{\mathrm{d}} \cdot \mathrm{C}_{\mathrm{a}} \\
& \mathrm{M}_{\mathrm{s}}=\mathrm{V} \cdot \rho \cdot \mathrm{C}_{\mathrm{s}} \cdot 10^{-3} \\
& \mathrm{~V}_{\mathrm{e}}=\pi \cdot \mathrm{R}^{2} \cdot \mathrm{h} \cdot \mathrm{n}_{\mathrm{e}} \\
& \mathrm{M}_{\mathrm{o}}=\mathrm{V} \cdot \rho \cdot \mathrm{SOD} \\
& \mathrm{V}_{\mathrm{as}}=\mathrm{M}_{\mathrm{o}} / \mathrm{C}_{\mathrm{o}}
\end{aligned}
$$

Onde,

$A=$ Área impactada $\left(\mathrm{m}^{2}\right)$

$\mathrm{V}=$ Volume de solo saturado contaminado $\left(\mathrm{m}^{3}\right)$

$\mathrm{h}=$ Espessura saturada contaminada do aquífero $(\mathrm{m})$

$\mathrm{K}_{\mathrm{d}}=$ Coeficiente de distribuição ou de partição $(\mathrm{mg} / \mathrm{g})$

$\mathrm{K}_{\mathrm{oc}}=$ Coeficiente de partição de carbono orgânico $(\mathrm{mg} / \mathrm{g})$

$\mathrm{f}_{\mathrm{oc}}=$ Fração de carbono orgânico contida no solo (\%)

$\mathrm{C}_{\mathrm{a}}=$ Concentração média dissolvida na água subterrânea $(\mathrm{mg} / \mathrm{L})$

$\mathrm{C}_{\mathrm{s}}=$ Concentração média adsorvida no solo $(\mathrm{mg} / \mathrm{kg})$

$\rho=$ Densidade do solo $\left(\mathrm{g} / \mathrm{cm}^{3}\right)$

$\mathrm{M}_{\mathrm{s}}=$ Massa de contaminante no solo saturado $(\mathrm{kg})$

$R=$ Raio de influência por poço de injeção $(m)$

$\mathrm{V}_{\mathrm{e}}=$ Volume efetivo de solo contaminado que terá contato com o oxidante por poço de injeção $\left(\mathrm{m}^{3}\right)$

$\mathrm{n}_{\mathrm{e}}=$ Porosidade efetiva $(\%)$

$\mathrm{SOD}=$ Demanda de oxidante no solo $\left(\mathrm{g} \mathrm{KMnO}_{4} / \mathrm{kg}\right.$ solo $)$ 
$\mathrm{M}_{\mathrm{o}}=$ Massa de Oxidante $(\mathrm{kg})$

$\mathrm{C}_{0}=$ Concentração do oxidante (\%)

$\mathrm{V}_{\mathrm{as}}=$ Volume de água para solução $(\mathrm{L})$

Com o conhecimento da dosagem e volume de solução de permanganato de potássio ideais para a realização do teste piloto de maneira a atingir os resultados desejados, partiu-se para a instalação do sistema de injeção. Todo o sistema de injeção (tanques e bombas) foi instalado em uma bacia de contenção feita de concreto e com capacidade de $20 \mathrm{~m}^{3}$, para evitar possíveis danos ao meio ambiente ou às pessoas presentes no local em caso de vazamento. Toda a solução foi preparada em um tanque de mistura de $1 \mathrm{~m}^{3}$ e encaminhada para dois tanques de $10 \mathrm{~m}^{3}$ para posterior injeção.

A tubulação e equipamentos do sistema de injeção foram construídos de PVC e PEAD (polietileno de alta densidade), por apresentarem compatibilidade química com o permanganato de potássio, evitando deterioração das peças em contato com a solução injetada pela oxidação.

Os poços de injeção e de monitoramento nas proximidades foram constantemente monitorados para evitar excesso de pressão, o que poderia causar vazamentos da solução nas linhas e nos poços de injeção e afloramento do nível d'água causado pelo volume injetado.

Para avaliar a eficiência da ação do permanganato frente ao contaminante presente no meio, amostras de água subterrânea foram coletadas e analisadas para VOC. A avaliação geoquímica da área foi comprometida, já que não foi possível para o laboratório a realização de análises químicas para avaliação das concentrações de metais dissolvidos na água subterrânea na presença de permanganato de potássio. Tal decisão por parte do laboratório foi tomada de forma a evitar possíveis danos aos equipamentos. Pelo mesmo motivo, os parâmetros físico-químicos ( $\mathrm{pH}, \mathrm{ORP}$, temperatura e condutividade elétrica) não puderam ser medidos em campo após a injeção da solução oxidante.

Como procedimento de amostragem, a água subterrânea coletada com presença de permanganato de potássio para análise de VOC foi neutralizada com tiosulfato de sódio para que as características da contaminação fossem representativas do momento da coleta, mas para isso não puderam ser preservadas com $\mathrm{HCl}$, apenas refrigeradas até a entrega no laboratório e análise química.

\subsubsection{INJEÇÃo do OXIDANTE EM ESCALA DE REMEDIAÇÃo}

A implantação do sistema de remediação ISCO em toda a área contaminada foi realizada de forma semelhante ao teste piloto, com: 1) instalação de poços de injeção; 2) injeção do agente oxidante; 3) monitoramento do comportamento do aquífero freático e 4) monitoramentos de desempenho do $\mathrm{KMnO}_{4}$ em diminuir as concentrações de 1,1-DCE. 
Após avaliação das configurações das plumas de 1,1-DCE e as características físico-químicas da área, foram instalados trinta e um poços de injeção em adição aos nove existentes, com profundidades variando entre 18 e $20 \mathrm{~m}$. Os perfis construtivos destes poços são semelhantes ao apresentado na Figura 14, de forma que o oxidante injetado pudesse entrar em contato com o contaminante presente em toda a seção saturada do aquífero freático.

Todo o cálculo de dosagem do permanganato de potássio e volume de solução necessários para que houvesse o maior contato possível do oxidante com o contaminante foi conduzido de acordo com as equações (11) a (17), apresentadas anteriormente.

Durante a etapa de injeção da solução do permanganato, o aquífero freático foi monitorado de forma a identificar a presença do oxidante e variação do nível de água dos poços de monitoramento. Estas atividades foram realizadas durante todo o período de injeção e forneceram informações importantes quanto ao real raio de influência do oxidante.

Os monitoramentos para avaliar a eficiência do processo de remediação ocorreram em um, três, seis, quinze e vinte e dois meses após a injeção do permanganato. Nestes períodos, foram coletadas amostras de água subterrânea para análises químicas de VOC e metais dissolvidos, para indicar, respectivamente, o abatimento da massa de contaminante e possível mobilização de compostos presentes naturalmente no meio. Assim como o ocorrido durante o teste piloto, nos poços de monitoramento onde a presença de permanganato de potássio foi observada, a coleta de amostras para análise não foi possível, assim como também não foram realizadas medições dos parâmetros físico-químicos visando a não danificação dos aparelhos.

\section{APRESENTAÇÃO E INTERPRETAÇÃO DOS RESULTADOS DO TESTE PILOTO UTILIZANDO ISCR}

\subsection{ENSAIOS EM CAMPO E EM LABORATÓRIO}

\section{Teste de injeção de água}

Com a finalidade de estudar o comportamento do aquífero frente à injeção de líquidos, foram realizados testes de injeção com água nos poços de injeção instalados.

Os resultados das interferências observadas no aquífero são apresentados nas Tabelas 9 e 10. 
Tabela 9 - Avaliação dos resultados do teste de injeção de água (poços de injeção RW-01 e RW-02)

\begin{tabular}{|c|c|c|c|c|c|c|c|}
\hline & & RW-01 & & & & RW-02 & \\
\hline Poço & $\begin{array}{l}\text { Distância } \\
\text { (m) }\end{array}$ & $\begin{array}{c}\text { Direção em } \\
\text { relação ao RW-01 }\end{array}$ & $\begin{array}{c}\text { Variação do nível } \\
\text { de água (m) }\end{array}$ & Poço & $\begin{array}{l}\text { Distância } \\
\text { (m) }\end{array}$ & $\begin{array}{c}\text { Direção em } \\
\text { relação ao RW-02 }\end{array}$ & $\begin{array}{c}\text { Variação do nível } \\
\text { de água (m) }\end{array}$ \\
\hline RW-02 & 13,00 & Jusante & 3,240 & RW-01 & 13,00 & Montante & 0,924 \\
\hline MW-06 & 48,00 & Montante & 0,000 & MW-06 & 37,00 & Montante & 0,000 \\
\hline$M W-12$ & 38,00 & Montante & 0,016 & MW-12 & 51,00 & Montante & 0,000 \\
\hline$M W-13$ & 12,00 & Jusante & 0,038 & $M W-13$ & 3,00 & Montante & 1,745 \\
\hline$M W-14$ & 38,00 & Montante & 0,008 & MW-14 & 3,00 & Jusante & 0,005 \\
\hline MW-15 & 58,00 & Jusante & 0,005 & MW-15 & 45,00 & Jusante & 0,005 \\
\hline MW-22 & 32,00 & Montante & 0,000 & MW-22 & 31,00 & Montante & 0,000 \\
\hline MW-23 & 3,00 & Montante & 0,530 & MW-23 & 15,00 & Montante & $-0,007$ \\
\hline MW-24 & 6,00 & Jusante & 0,190 & MW-24 & 9,00 & Montante & 0,250 \\
\hline MW-25 & 6,00 & Jusante & 0,010 & MW-25 & 9,00 & Montante & 0,010 \\
\hline MW-28 & 59,00 & Jusante & 0,013 & MW-28 & 54,00 & Jusante & 0,016 \\
\hline MW-29 & 59,00 & Jusante & 0,030 & MW-29 & 54,00 & Jusante & 0,015 \\
\hline MW-104 & 70,00 & Jusante & 0,018 & MW-104 & 59,00 & Jusante & 0,000 \\
\hline MW-105 & 70,00 & Jusante & 0,010 & MW-105 & 59,00 & Jusante & 0,000 \\
\hline MW-108 & 37,00 & Jusante & 0,065 & MW-108 & 46,00 & Jusante & 0,000 \\
\hline
\end{tabular}

As medições de nível d'água mostraram que houve uma maior resposta do aquífero no teste realizado no poço de injeção RW-02. Embora tenham sido observados valores consideráveis de elevação do nível d'água em poços até $59 \mathrm{~m}$ de distância, não significa que esta foi a distância de caminhamento da água injetada, e sim apenas reflexo do volume injetado, intensificando o fluxo da água subterrânea.

O volume total de água injetada no RW-01 foi de $811 \mathrm{~L}$ (vazão média de $213 \mathrm{~L} / \mathrm{h}$, onde a vazão inicial foi de $810 \mathrm{~L} / \mathrm{h}$ e a final de $135 \mathrm{~L} / \mathrm{h}$ ).

No poço RW-02, o volume total de água injetada foi de $5.267 \mathrm{~L}$ (vazão média em torno de $940 \mathrm{~L} / \mathrm{h}$, com vazão inicial de $847 \mathrm{~L} / \mathrm{h}$ e final de $1097 \mathrm{l} / \mathrm{h}$ ) 
Tabela 10 - Avaliação dos resultados do teste de injeção de água (poços de injeção RW-03 e RW-04)

\begin{tabular}{|c|c|c|c|c|c|c|c|}
\hline \multicolumn{4}{|c|}{ RW-03 } & \multicolumn{4}{|c|}{ RW-04 } \\
\hline Poço & $\begin{array}{c}\text { Distância } \\
\text { (m) }\end{array}$ & $\begin{array}{c}\text { Direção em } \\
\text { relação ao RW-01 }\end{array}$ & $\begin{array}{c}\text { Variação do nível } \\
\text { de água (m) }\end{array}$ & Poço & $\begin{array}{l}\text { Distância } \\
\text { (m) }\end{array}$ & $\begin{array}{c}\text { Direção em } \\
\text { relação ao RW-02 }\end{array}$ & $\begin{array}{c}\text { Variação do nível } \\
\text { de água (m) }\end{array}$ \\
\hline RW-01 & 20,00 & Jusante & 0,000 & RW-01 & 38 & Jusante & 0,000 \\
\hline RW-02 & 10,00 & Jusante & 0,005 & RW-02 & 28 & Jusante & 0,000 \\
\hline RW-04 & 18,00 & Montante & $-0,125$ & RW-03 & 18 & Jusante & $-0,015$ \\
\hline MW-06 & 29,00 & Montante & $-0,215$ & MW-06 & 12 & Jusante & 0,650 \\
\hline$M W-13$ & 9,00 & Jusante & 0,005 & MW-13 & 28 & Montante & 0,000 \\
\hline$M W-14$ & 18,00 & Montante & $-1,050$ & MW-14 & 2 & Jusante & 4,260 \\
\hline MW-15 & 13,00 & Jusante & 0,010 & MW-15 & 37 & Jusante & 0,000 \\
\hline$M W-16$ & 54,00 & Jusante & 0,000 & MW-16 & 42 & Jusante & $-0,095$ \\
\hline MW-22 & 22,00 & Montante & $-0,005$ & MW-22 & 25 & Montante & 0,035 \\
\hline MW-23 & 19,00 & Jusante & 0,000 & MW-23 & 38 & Montante & 0,000 \\
\hline MW-24 & 18,00 & Jusante & 0,000 & MW-24 & 37 & Montante & 0,000 \\
\hline MW-25 & 18,00 & Jusante & $-0,005$ & MW-25 & 37 & Montante & $-0,010$ \\
\hline$M W-104$ & 63,00 & Jusante & 0,000 & MW-104 & 65 & Jusante & 0,000 \\
\hline MW-105 & 63,00 & Jusante & $-0,010$ & MW-105 & 65 & Jusante & 0,000 \\
\hline
\end{tabular}

Nos testes realizados nos poços de injeção RW-03 e RW-04, foi identificado variação do nível d'água em poços localizados em até $12 \mathrm{~m}$ de distância do poço de injeção mais próximo.

No poço RW-03, o volume total de água injetado foi de $140 \mathrm{~L}$ (com vazão média de injeção de $160 \mathrm{l} / \mathrm{h}$, sendo a inicial de $840 \mathrm{~L} / \mathrm{h}$ e final de $1,8 \mathrm{~L} / \mathrm{h}$ ).

O volume total injetado no poço RW-04 foi de 10.751 L (com vazão média de 1.327 $\mathrm{L} / \mathrm{h}$, inicial de $660 \mathrm{~L} / \mathrm{h}$ e final de $1.680 \mathrm{~L} / \mathrm{h}$ ).

Entre todos os dados obtidos, nota-se que dois poços apresentaram valores de injeção muito baixos (RW-01 e RW-03), mostrando uma baixa eficiência na dissipação da água injetada, apesar de todos os poços terem sido instalados seguindo metodologias idênticas.

A partir dos resultados obtidos, estimou-se que o raio de influência poderia ser considerado entre 3 e $6 \mathrm{~m}$.

Análises laboratoriais para avaliar teor de ferro no solo e eficiência de potenciais redutores

A Tabela 11 apresenta os resultados das análises químicas realizadas para avaliar a compatibilidade do teor de ferro III, presente no aquífero, com a aplicação da metodologia relacionada à redução química para eliminação dos contaminantes organoclorados. 
Tabela 11 - Caracterização inicial do teor de ferro III

\begin{tabular}{cccc}
\hline $\begin{array}{c}\text { Ponto de } \\
\text { amostragem }\end{array}$ & $\begin{array}{c}\text { Profundidade } \\
\text { coletada }(\mathbf{m})\end{array}$ & $\begin{array}{c}\text { Teor de ferro III } \\
(\mathbf{g} / \mathbf{k g})\end{array}$ & $\begin{array}{c}\text { Teor de ferro III } \\
(\%)\end{array}$ \\
\hline \multirow{2}{*}{ RW-03 } & 12 & 47,40 & 4,74 \\
& 15 & 63,60 & 6,36 \\
& 18 & 48,30 & 4,83 \\
\hline \multirow{2}{*}{ RW-04 } & 12 & 25,00 & 2,50 \\
& 15 & 23,90 & 2,39 \\
& 17 & 45,00 & 4,50 \\
\hline
\end{tabular}

Segundo Vermuel et al. (2000), é necessário que a ocorrência natural de ferro III no aquífero seja de no mínimo $0,05 \%$ da fração de solo total para que este possa ser potencialmente reduzido para ferro II na presença de um agente redutor, que consequentemente promoverá a decloração redutiva dos compostos organoclorados.

Embora o teor de ferro III encontrado no material geológico do aquífero contaminado tenha sido classificado como satisfatório, foi necessário avaliar também as concentrações de ferro II potencialmente disponíveis para reduzir os contaminantes. Os resultados estão descritos na Tabela 12.

Tabela 12 - Caracterização inicial do teor de ferro II

\begin{tabular}{|c|c|c|c|}
\hline $\begin{array}{c}\text { Ponto de } \\
\text { amostragem }\end{array}$ & $\begin{array}{c}\text { Profundidade } \\
\text { coletada }(\mathrm{m})\end{array}$ & $\begin{array}{c}\text { Teor médio de ferro } \\
\text { total }(\mathrm{mg} / \mathrm{kg})\end{array}$ & $\begin{array}{c}\text { Teor médio de ferro } \\
\text { II }(\mathrm{mg} / \mathrm{kg})\end{array}$ \\
\hline \multirow{2}{*}{ Ponto 1} & $11,5-12,9$ & 25.300 & $1.353,20$ \\
\hline & $15,0-16,0$ & 4.940 & 601,40 \\
\hline \multirow{2}{*}{ Ponto 2} & $11,5-12,9$ & 14.200 & $1.052,50$ \\
\hline & $17,5-18,5$ & 17.300 & 902,20 \\
\hline \multirow{2}{*}{ Ponto 3} & $11,5-12,9$ & 16.900 & $1.052,50$ \\
\hline & $17,5-18,5$ & 7.640 & 751,80 \\
\hline Concentração média & - & 14.380 & 952,30 \\
\hline $\begin{array}{c}\text { Teor médio de ferro II } \\
(\%)\end{array}$ & - & - & 6.6 \\
\hline
\end{tabular}

Szecsody et al. (2004), acompanhando a decloração redutiva de TCE em aquiferos sedimentares, constatou que em alguns casos a decloração redutiva poderia não ocorrer na presença de sedimentos naturais com baixa concentração de ferro II $(<3 \%)$.

De acordo com as duas citações, as concentrações de ferro III e ferro III disponíveis no aquífero foram consideradas como apresentando potencial para a decloração redutiva abiótica dos contaminantes solventes clorados. Com base nisso, partiu-se para os testes de tratabilidade que envolveram a avaliação do desempenho de quatro agentes redutores em reduzir o ferro III identificado naturalmente no aquífero, para que as reações entre o ferro bivalente a os contaminantes organoclorados presentes na água subterrânea pudessem ocorrer de forma satisfatória. Os resultados destes testes são apresentados na Tabela 13. 
Tabela 13 - Resultados da avaliação eliminatória de potenciais agentes redutores

\begin{tabular}{ccc}
\hline Tratamentos & $\begin{array}{c}\text { Adição de carbonato } \\
\text { de sódio? }\end{array}$ & $\begin{array}{c}\text { Concentração de } \\
\text { ferro Il ou FeS } \\
\text { (mg/kg) }\end{array}$ \\
\hline \multirow{2}{*}{ Sulfeto de Sódio* } & Não & $3.909^{*}$ \\
& Sim & $2.405^{*}$ \\
\hline \multirow{2}{*}{ Polisulfeto de Cálcio } & Não & 2.105 \\
& Sim & 3.368 \\
\hline \multirow{2}{*}{ Ditionita de Sódio } & Não & 1.504 \\
& Sim & 1.804 \\
\hline \multirow{2}{*}{ Oxalato de Sódio } & Não & 2.105 \\
& Sim & 1.504 \\
\hline
\end{tabular}

Nota: ${ }^{*}$ ) formação de sulfeto ferroso (FeS)

Observando os resultados obtidos na Tabela 13, verifica-se que todos os agentes redutores disponibilizaram concentrações maiores de ferro II quando comparadas à caracterização inicial (Tabela 12). A adição de carbonato de sódio implicou em resultados finais de efeitos mistos. Os melhores resultados foram observados com a utilização do sulfeto de sódio, seguido do polisulfeto de cálcio.

Com base nos resultados deste primeiro teste de tratabilidade, foram realizados os estudos de microcosmos, onde a eficiência dos melhores agentes redutores foi avaliada pela redução dos contaminantes solventes clorados presentes no aquífero da área de estudo. Assim, os dois agentes redutores selecionados foram adicionados ao solo contaminado coletado e os resultados foram acompanhados pelo período de 117 dias. As Figuras 15 e 16 ilustram, respectivamente, os resultados da degradação dos contaminantes 1,1-DCE e 1,1-DCA. Tais compostos foram selecionados por apresentarem as maiores concentrações identificadas no local.

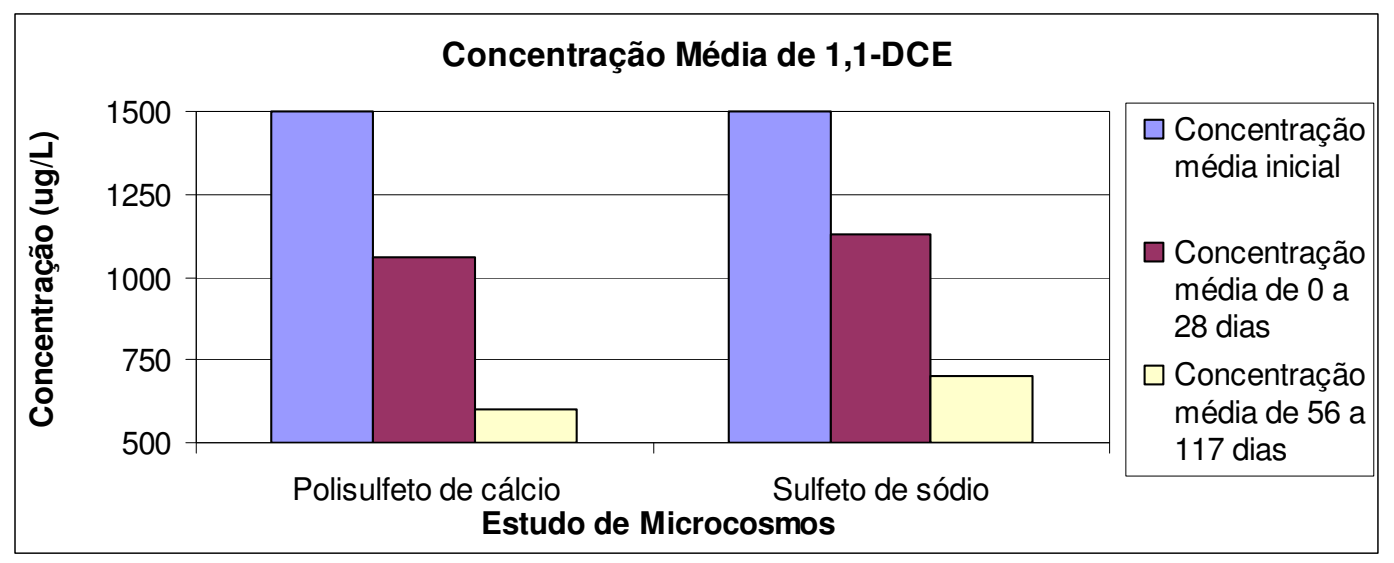

Figura 15 - Resultados dos ensaios de microcosmos para 1,1-DCE 


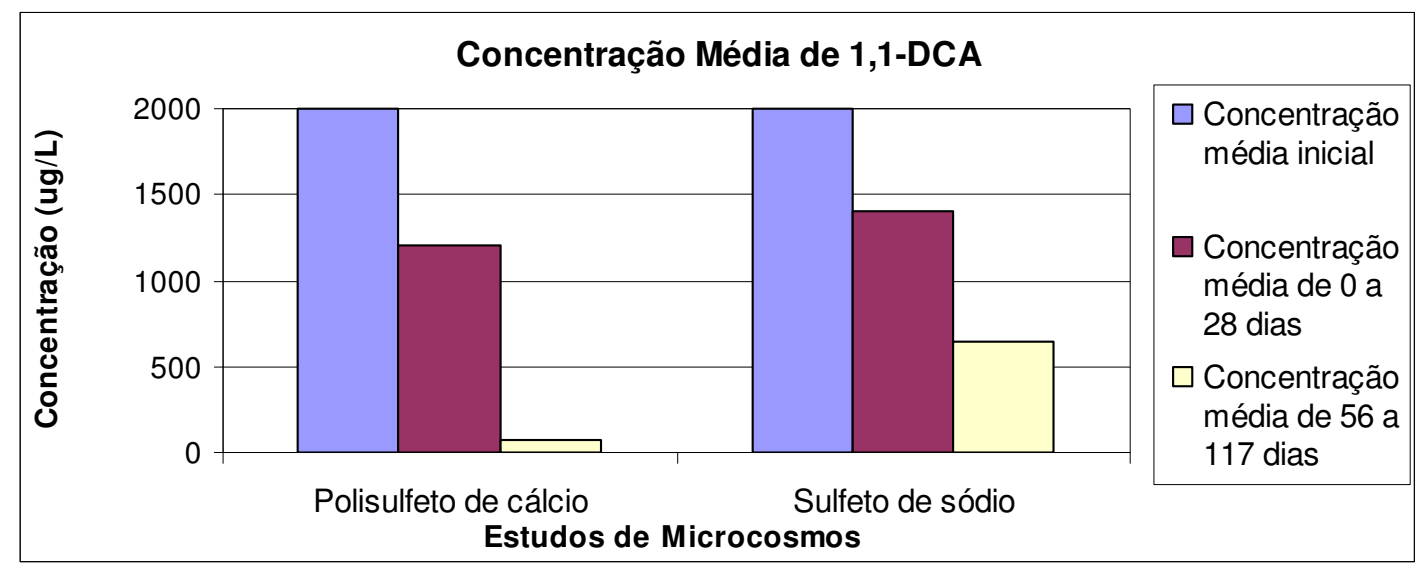

Figura 16 - Resultados dos ensaios de microcosmos para 1,1-DCA

Como apresentado nas Figuras 15 e 16, o redutor polisulfeto de cálcio mostrou-se mais eficiente, principalmente na degradação do composto 1,1-DCA.

De acordo com o laboratório, a dosagem ideal para aplicação do produto (que apresentava concentração de enxofre de $23 \%$ ) no teste piloto deveria ser a diluição de $75 \mathrm{~L}$ de polisulfeto de cálcio a cada $2.000 \mathrm{~L}$ de água. O polisulfeto de cálcio, conhecido nos Estados Unidos da América como lime sulfur, é um fungicida/herbicida facilmente adquirido em comércios do ramo.

Dado o conjunto de informações obtidas ao longo das etapas dos testes de tratabilidade em laboratório, foi possível selecionar entre as opções disponíveis o agente redutor polisulfeto de cálcio para a realização do teste piloto com a metodologia de ISCR na Área 1.

\subsection{INJEÇÃo do REDUTOR EM ESCALA DE TESTE PILOTO}

É importante salientar que o polisulfeto de cálcio, no período em que o teste piloto foi realizado, era comercializado por apenas um fornecedor no Brasil, e apresentava concentração de enxofre de $18 \%$, ao invés de $23 \%$ como utilizado no teste de tratabilidade. Segundo o laboratório, isso significaria apenas uma maior diluição do produto, modificando a dosagem para $85 \mathrm{~L}$ do redutor a cada $2.000 \mathrm{~L}$ de água. Outra característica distinta entre os produtos foi a solubilidade, embora não mensurável, observou-se em campo que o utilizado no teste piloto apresentava-se com alta viscosidade.

Os resultados obtidos durante as atividades do teste piloto serão apresentados em dois segmentos principais: parâmetros físico-químicos sendo representados pelos dados de $\mathrm{pH}$, ORP e condutividade elétrica; e as análises químicas de laboratório. Os dados apresentados são referentes às atividades realizadas desde a caracterização inicial até a 
última coleta, após os onze meses da injeção.

Todos os resultados são apresentados considerando os poços de monitoramento que se encontram sob influência dos poços de injeção utilizados no teste piloto. Assim o conjunto do poço de injeção RW-02, corresponde aos poços de monitoramento MW-13, MW-301 ao MW-303, e o conjunto do poço de injeção RW-04 corresponde aos poços de monitoramento MW-14, MW-304 ao MW-306 (Figura 13).

\subsubsection{SUMÁRIO dOS DAdOS de PARÂmetros Físico-Químicos}

A partir dos resultados do teste de tratabilidade em laboratório que avaliou a eficiência do polisulfeto de cálcio em reduzir os contaminantes presentes no aquífero da Área 1, foi indicado qual a dosagem necessária para que o teste piloto pudesse ser efetivo, de acordo com as concentrações de VOC observadas no local.

Para tanto, $425 \mathrm{~L}$ de polisulfeto de cálcio foram adicionados à cada um dos reservatórios de $10.000 \mathrm{~L}$ utilizados no teste piloto, completados com água subterrânea obtida da extração do aquífero contaminado e água de abastecimento público.

Durante o processo de mistura foi realizada a medição dos parâmetros físicoquímicos a cada $2.000 \mathrm{~L}$ de solução preparada até que todo o tanque de injeção estivesse completo. O polisulfeto de cálcio foi adicionado gradativamente ao tanque de mistura, o que proporcionou a alteração dos parâmetros analisados. Durante o preparo da solução foi observado o aumento dos valores de $\mathrm{pH}$, o que tornou a solução gradativamente mais alcalina para ambas as áreas de injeção. Já o potencial de oxi-redução apresentou queda atingindo valores negativos, o que caracterizou o comportamento redutor da solução. Essas alterações anteriores ao contato com o meio aquífero se devem ao fato de que o próprio produto apresenta características alcalinas e redutoras. A condutividade elétrica aumentou de forma a exceder o limite da escala do aparelho utilizado. Para este último parâmetro, pode ter ocorrido aumento em função de reações com os sólidos em suspensão presentes na água retirada da área, fazendo com que fossem liberados íons na solução. A Tabela 14 apresenta os dados dos parâmetros físico-químicos relativos à mistura momentos antes da injeção.

Tabela 14 - Parâmetros físico-químicos nos tanques de injeção

\begin{tabular}{cccc}
\hline Tanque & \multicolumn{4}{c}{ Parâmetros medidos durante a mistura do agente redutor } \\
& $\mathrm{pH}$ & ORP $(\mathbf{m V})$ & Cond. Elétrica $(\boldsymbol{\mu S} / \mathbf{c m})$ \\
\hline Tanque 01 (RW-02) & 10,94 & -227 & $>>2100$ \\
Tanque 02 (RW-04) & 10,91 & -226 & $>>2100$ \\
\hline
\end{tabular}


Estes mesmos parâmetros foram analisados durante a caracterização inicial e na avaliação de desempenho até onze meses após a injeção do agente redutor. A seguir serão apresentados separadamente os parâmetros físico-químicos obtidos ao longo das etapas.

\section{Variação de $\mathrm{pH}$}

A Tabela 15 aponta a variação de $\mathrm{pH}$ obtida a partir da estabilização dos parâmetros ao longo das atividades de monitoramento.

De maneira geral, observa-se um aumento dos valores de $\mathrm{pH}$ nos poços onde o agente redutor teve acesso, embora houvesse variações de comportamento. Essa variação foi observada nos próprios poços de injeção, de maneira que o poço RW-04 apresentou elevados valores de $\mathrm{pH}$ até o final dos onze meses de monitoramento, enquanto que o RW-02 apresentou decréscimo acentuado em relação aos valores de pico já no primeiro mês de monitoramento.

Tabela 15 - Valores de pH ao longo do monitoramento

\begin{tabular}{|c|c|c|c|c|c|c|c|c|c|c|c|c|c|c|}
\hline \multirow{3}{*}{\multicolumn{2}{|c|}{$\begin{array}{c}\text { Poço } \\
\text { (Localização) }\end{array}$}} & \multirow{4}{*}{$\begin{array}{c}\text { Caract } \\
\text { inicial } \\
\text { Mar } \\
07\end{array}$} & \multirow{2}{*}{\multicolumn{8}{|c|}{$\mathrm{pH}$}} & \multirow{2}{*}{\multicolumn{4}{|c|}{$\begin{array}{c}\text { Monitoramento de } \\
\text { desempenho }\end{array}$}} \\
\hline & & & & & & & & & & & & & & \\
\hline & & & \multirow{2}{*}{$\begin{array}{l}\text { Dia da } \\
\text { injeção } \\
22 \text { mai } \\
07\end{array}$} & \multirow{2}{*}{$\begin{array}{c}1 \text { dia } \\
23 \text { mai } \\
07\end{array}$} & \multirow{2}{*}{$\begin{array}{c}2 \text { dias } \\
24 \text { mai } \\
07\end{array}$} & \multirow{2}{*}{$\begin{array}{c}3 \text { dias } \\
25 \text { mai } \\
07\end{array}$} & \multirow{2}{*}{$\begin{array}{c}4 \text { dias } \\
26 \text { mai } \\
07\end{array}$} & \multirow{2}{*}{$\begin{array}{c}5 \text { dias } \\
27 \text { mai } \\
07\end{array}$} & \multirow{2}{*}{$\begin{array}{c}6 \text { dias } \\
28 \text { mai } \\
07\end{array}$} & \multirow{2}{*}{$\begin{array}{c}7 \text { dias } \\
29 \text { mai } \\
07\end{array}$} & \multirow{2}{*}{$\begin{array}{c}1 \\
\text { mês } \\
\text { jul } \\
07\end{array}$} & \multirow{2}{*}{$\begin{array}{c}3 \\
\text { meses } \\
\text { set } \\
07\end{array}$} & \multirow{2}{*}{$\begin{array}{c}6 \\
\text { meses } \\
\text { dez } \\
07\end{array}$} & \multirow{2}{*}{$\begin{array}{c}11 \\
\text { meses } \\
\text { mai } \\
08\end{array}$} \\
\hline & & & & & & & & & & & & & & \\
\hline \multicolumn{15}{|c|}{ Poços de montante mais distantes } \\
\hline$M W-22$ & Montante & 5,66 & 4,70 & 5,35 & 5,25 & 5,18 & 5,45 & 5,20 & 5,10 & 5,00 & 5,43 & 5,87 & 5,10 & 5,59 \\
\hline$M W-23$ & Montante & 5,44 & 5,23 & 5,30 & 5,02 & 5,18 & 5,31 & 5,15 & 4,85 & 4,70 & 5,54 & 5,63 & 5,15 & 5,43 \\
\hline \multicolumn{15}{|c|}{ Conjunto RW-02 } \\
\hline$M W-13$ & Montante & 5,39 & 9,00 & 8,65 & 6,68 & 8,20 & 6,60 & 7,30 & 5,05 & 6,80 & 6,03 & 5,35 & 5,48 & 4,94 \\
\hline RW-02 & Injeção & 3,92 & 11,43 & 11,09 & 10,78 & 11,25 & 10,30 & 10,87 & 10,84 & 11,04 & 7,76 & 6,70 & 6,30 & 6,70 \\
\hline MW-301 & Jusante & 6,44 & 9,00 & 9,25 & 6,70 & 9,09 & 8,85 & 8,53 & 8,14 & 8,20 & 7,04 & 6,33 & 6,21 & 6,25 \\
\hline MW-302 & Jusante & 6,95 & 6,05 & 6,11 & 6,20 & 7,11 & 6,40 & 6,21 & 5,95 & 5,60 & 5,97 & 5,99 & 5,46 & 5,24 \\
\hline MW-303 & Jusante & 6,40 & 9,69 & 9,69 & 9,25 & 9,38 & 9,10 & 8,90 & 8,55 & 8,51 & 7,72 & 6,81 & 6,40 & 6,70 \\
\hline \multicolumn{15}{|c|}{ Conjunto RW-04 } \\
\hline$M W-14$ & Montante & 5,19 & 9,20 & 9,11 & 9,38 & 9,32 & 9,20 & 9,01 & 8,55 & 8,28 & 6,63 & 5,93 & 4,93 & 5,40 \\
\hline RW-04 & Injeção & 5,74 & 10,41 & 11,13 & 11,14 & 11,05 & 11,28 & 11,25 & 11,08 & 11,26 & 11,12 & 10,73 & 10,09 & 8,48 \\
\hline MW-304 & Jusante & 6,99 & 6,25 & 5,98 & 6,53 & 6,50 & 6,64 & 6,65 & 6,40 & 6,31 & 6,23 & 5,97 & 5,60 & 5,93 \\
\hline MW-305 & Jusante & 6,91 & 6,26 & 6,08 & 6,75 & 6,54 & 7,20 & 6,61 & 6,36 & 6,18 & 6,77 & 6,60 & 6,20 & 5,61 \\
\hline MW-306 & Jusante & 7,09 & 6,12 & 6,05 & 6,61 & 6,55 & 6,53 & 6,61 & 6,38 & 6,20 & 6,52 & 6,54 & 6,08 & 6,10 \\
\hline
\end{tabular}

Dentre os poços a montante, os que melhor responderam à variação de $\mathrm{pH}$ em função do agente redutor foram aqueles mais próximos aos poços de injeção (MW-13 e MW-14). Nos poços a montante, mais distantes (MW-22 e MW-23), não foi identificada 
variação, o que era esperado, visto que estes poços foram selecionados para monitorarem possíveis alterações naturais nos parâmetros químicos e físico-químicos do aquífero impactado, por não haver possibilidade de influência do redutor.

Já nos poços a jusante, foi observado no conjunto RW-02, que os poços MW-301 e MW-303 apresentaram maiores variações durante o monitoramento inicial após a injeção e tenderam a estabilizar ao longo do monitoramento de desempenho. A mesma situação não ocorreu com o poço MW-302 e com os poços a jusante referentes ao ponto de injeção RW-04, onde as medidas permaneceram estáveis ao longo do período do teste.

\section{Variação do Potencial de Oxi-redução}

A Tabela 16 aponta a variação do ORP obtido a partir da estabilização dos parâmetros ao longo das atividades de monitoramento.

Tabela 16 - Valores de potencial de oxi-redução ao longo do monitoramento

\begin{tabular}{|c|c|c|c|c|c|c|c|c|c|c|c|c|c|c|}
\hline \multirow{4}{*}{\multicolumn{2}{|c|}{$\begin{array}{c}\text { Poço } \\
\text { (Localização) }\end{array}$}} & \multicolumn{13}{|c|}{ Potencial de Oxi-redução (mV) } \\
\hline & & \multirow{3}{*}{$\begin{array}{c}\text { Caract } \\
\text { inicial } \\
\text { mar } \\
07\end{array}$} & \multicolumn{8}{|c|}{ Monitoramento inicial pós-injeção } & \multicolumn{4}{|c|}{$\begin{array}{l}\text { Monitoramento de } \\
\text { desempenho }\end{array}$} \\
\hline & & & \multirow{2}{*}{$\begin{array}{c}\text { Dia da } \\
\text { injeção } \\
22 \text { mai } \\
07\end{array}$} & \multirow{2}{*}{$\begin{array}{c}1 \text { dia } \\
23 \text { mai } \\
07\end{array}$} & \multirow{2}{*}{$\begin{array}{c}2 \text { dias } \\
24 \text { mai } \\
07\end{array}$} & \multirow{2}{*}{$\begin{array}{c}3 \text { dias } \\
25 \text { mai } \\
07\end{array}$} & \multirow{2}{*}{$\begin{array}{c}4 \text { dias } \\
26 \text { mai } \\
07\end{array}$} & \multirow{2}{*}{$\begin{array}{c}5 \text { dias } \\
27 \text { mai } \\
07\end{array}$} & \multirow{2}{*}{$\begin{array}{c}6 \text { dias } \\
28 \text { mai } \\
07\end{array}$} & \multirow{2}{*}{$\begin{array}{c}7 \text { dias } \\
29 \text { mai } \\
07\end{array}$} & \multirow{2}{*}{$\begin{array}{c}1 \\
\text { mês } \\
\text { Jul } \\
07\end{array}$} & \multirow{2}{*}{$\begin{array}{c}3 \\
\text { meses } \\
\text { set } \\
07\end{array}$} & \multirow{2}{*}{$\begin{array}{c}6 \\
\text { meses } \\
\text { dez } \\
07\end{array}$} & \multirow{2}{*}{$\begin{array}{c}11 \\
\text { meses } \\
\text { mai } \\
08\end{array}$} \\
\hline & & & & & & & & & & & & & & \\
\hline \multicolumn{15}{|c|}{ Poços de montante mais distantes } \\
\hline MW-22 & Montante & 85 & 129 & 100 & 115 & 118 & 106 & 130 & 131 & 125 & 109 & 106 & 116 & 84 \\
\hline MW-23 & Montante & 98 & 102 & 104 & 131 & 124 & 115 & 126 & 137 & 143 & 102 & 100 & 116 & 94 \\
\hline \multicolumn{15}{|c|}{ Conjunto RW-02 } \\
\hline MW-13 & Montante & 104 & -120 & -89 & 38 & -40 & 58 & -3 & 95 & 50 & 79 & 110 & 98 & 119 \\
\hline RW-02 & Injeção & 180 & -251 & -230 & -201 & -228 & -176 & -204 & -208 & -219 & -20 & 50 & 61 & 32 \\
\hline MW-301 & Jusante & 44 & -111 & -125 & 33 & -101 & -87 & -69 & -50 & -48 & 25 & 57 & 60 & 57 \\
\hline MW-302 & Jusante & 14 & 50 & 50 & 70 & 13 & 53 & 67 & 78 & 90 & 84 & 80 & 90 & 104 \\
\hline MW-303 & Jusante & 47 & -151 & -150 & -110 & -116 & -101 & -90 & -73 & -69 & -14 & 36 & 57 & 32 \\
\hline \multicolumn{15}{|c|}{ Conjunto RW-04 } \\
\hline$M W-14$ & Montante & 115 & -124 & -118 & -120 & -115 & -106 & -96 & -73 & -57 & 44 & 82 & 132 & 97 \\
\hline RW-04 & Injeção & 75 & -196 & -234 & -224 & -219 & -228 & -229 & -219 & -234 & -219 & -201 & -163 & -70 \\
\hline MW-304 & Jusante & 12 & 41 & 62 & 49 & 44 & 42 & 42 & 50 & 57 & 68 & 81 & 92 & 70 \\
\hline MW-305 & Jusante & 17 & 40 & 61 & 39 & 42 & 16 & 43 & 49 & 61 & 40 & 47 & 66 & 87 \\
\hline MW-306 & Jusante & 6 & 56 & 53 & 44 & 45 & 47 & 41 & 55 & 64 & 50 & 50 & 81 & 62 \\
\hline
\end{tabular}

Similar às variações ocorridas com o parâmetro $\mathrm{pH}$, foi observado nos poços de injeção (RW-02 e RW-04) e nos poços a montante mais próximos (MW-13 e MW-14) uma maior variação do potencial de oxi-redução para valores negativos (caráter redutor) durante o monitoramento inicial pós-injeção. Exceto pelo poço RW-04, nota-se uma tendência à 
normalização ao longo do monitoramento de desempenho.

A mesma relação ocorreu com os poços à jusante, onde o MW-301 e MW-303, referentes ao conjunto RW-02, apresentaram as maiores variações durante 0 monitoramento inicial após a injeção. Já o poço MW-302 (pertencente ao conjunto RW-02) e os poços MW-304 ao MW-306 (pertencentes ao conjunto RW-04) não apresentaram variações negativas de potencial de oxi-redução.

\section{Variação de Condutividade}

A Tabela 17 apresenta a variação de condutividade elétrica obtida a partir da estabilização dos parâmetros ao longo das atividades de monitoramento.

Tabela 17 - Valores de condutividade elétrica ao longo do monitoramento

Condutividade elétrica $(\mu \mathrm{S} / \mathrm{cm})$

\begin{tabular}{|c|c|c|c|c|c|c|c|c|c|c|c|c|c|c|}
\hline \multirow{2}{*}{\multicolumn{2}{|c|}{$\begin{array}{c}\text { Poço } \\
\text { (Localização) }\end{array}$}} & \multirow{2}{*}{$\begin{array}{c}\text { Caract } \\
\text { inicial } \\
\text { mar } \\
07\end{array}$} & \multicolumn{8}{|c|}{ Monitoramento inicial pós-injeção } & \multicolumn{4}{|c|}{$\begin{array}{c}\text { Monitoramento de } \\
\text { desempenho }\end{array}$} \\
\hline & & & \multirow{2}{*}{$\begin{array}{c}\text { Dia da } \\
\text { injeção } \\
22 \text { mai } \\
07\end{array}$} & $\begin{array}{c}1 \text { dia } \\
23 \text { mai } \\
07\end{array}$ & $\begin{array}{c}2 \text { dias } \\
24 \text { mai } \\
07\end{array}$ & $\begin{array}{c}3 \text { dias } \\
25 \text { mai } \\
07\end{array}$ & $\begin{array}{c}4 \text { dias } \\
26 \text { mai } \\
07\end{array}$ & $\begin{array}{c}5 \text { dias } \\
27 \text { mai } \\
07\end{array}$ & $\begin{array}{c}6 \text { dias } \\
28 \text { mai } \\
07\end{array}$ & $\begin{array}{c}7 \text { dias } \\
29 \text { mai } \\
07\end{array}$ & $\begin{array}{c}1 \\
\text { mês } \\
\text { jul } \\
07\end{array}$ & $\begin{array}{c}3 \\
\text { meses } \\
\text { set } \\
07\end{array}$ & $\begin{array}{c}6 \\
\text { meses } \\
\text { dez } \\
07\end{array}$ & $\begin{array}{c}11 \\
\text { meses } \\
\text { mai } \\
08\end{array}$ \\
\hline \multicolumn{14}{|c|}{ Poços de montante mais distantes } & \\
\hline MW-22 & Montante & 120,1 & 130,9 & 120,1 & 132,2 & 130 & 275 & 209 & 164,1 & 141,3 & 95,7 & 135,3 & 88,2 & 105,1 \\
\hline MW-23 & Montante & 79,6 & 177,6 & 200,1 & 128 & 240 & 187 & 181 & 181,8 & 172,9 & 163,2 & 155,1 & 146,4 & 153,3 \\
\hline \multicolumn{15}{|c|}{ Conjunto RW-02 } \\
\hline MW-13 & Montante & 340 & $>2000$ & $>2000$ & 1795 & $>2100$ & 1815 & $>2100$ & 881 & 1893 & 1075 & 659 & 721 & 461 \\
\hline RW-02 & Injeção & 512 & $>2000$ & $>2000$ & $>2000$ & $>2100$ & $>2100$ & $>2100$ & $>2100$ & $>2100$ & 1842 & 1695 & $>2100$ & 1507 \\
\hline MW-301 & Jusante & 640 & $>2000$ & $>2000$ & 943 & $>2100$ & $>2100$ & $>2100$ & $>2100$ & $>2100$ & 1507 & 1120 & 1190 & 899 \\
\hline MW-302 & Jusante & 611 & 237 & 507 & 360 & 955 & 871 & 900 & 992 & 1170 & 1197 & 1251 & 1105 & 1170 \\
\hline MW-303 & Jusante & 907 & $>2000$ & $>2000$ & $>2000$ & $>2100$ & $>2100$ & $>2100$ & $>2100$ & $>2100$ & $>2100$ & 1981 & 1440 & 1271 \\
\hline \multicolumn{15}{|c|}{ Conjunto RW-04 } \\
\hline MW-14 & Montante & 66,2 & $>2000$ & $>2000$ & $>2100$ & $>2100$ & $>2100$ & 1808 & 1935 & 2035 & 680 & 403 & 350 & 287 \\
\hline RW-04 & Injeção & 163,1 & $>2000$ & $>2000$ & $>2100$ & $>2100$ & $>2100$ & $>2100$ & $>2100$ & $>2100$ & 1815 & 1599 & 1021 & 958 \\
\hline MW-304 & Jusante & 565 & 447 & 545 & 509 & 505 & 410 & 545 & 516 & 525 & 310 & 274 & 205 & 149,3 \\
\hline MW-305 & Jusante & 548 & 436 & 503 & 456 & 508 & 340 & 480 & 496 & 468 & 530 & 476 & 242 & 152,1 \\
\hline MW-306 & Jusante & 563 & 358 & 415 & 430 & 469 & 447 & 482 & 480 & 481 & 438 & 457 & 610 & 509 \\
\hline
\end{tabular}

Aparentemente, para os dados de condutividade elétrica, são observados os mesmos padrões dos demais parâmetros. Dessa forma, nota-se que os poços de injeção (RW-02 e RW-04), os poços de montante mais próximos (MW-13 e MW-14) e parte dos poços de jusante referentes ao conjunto RW-02 apresentam as maiores variações ao longo do monitoramento inicial após a injeção. Observa-se também um aumento mais lento e 
progressivo para o poço MW-302 ainda no monitoramento inicial com manutenção de valores altos ao longo dos monitoramentos de desempenho. Já para os demais poços que apresentaram indicações de acesso ao produto pelos parâmetros discutidos anteriormente, observa-se a tendência de queda de condutividade elétrica no primeiro mês após a injeção e ao longo dos monitoramentos de desempenho, exceto pelo poço a jusante, MW-302, que apresentou oscilações de valores mais altos nesse período.

\subsection{SUMÁRIO DAS ANÁLISES QUÍMICAS}

\subsubsection{COMPOSTOS ORGÂNICOS VOLÁTEIS}

Os resultados das análises químicas de VOC totais referentes à caracterização inicial e monitoramento de desempenho podem ser observados na Tabela 18, onde os dados são apresentados considerando o agrupamento dos poços de monitoramento em relação ao poço de injeção mais próximo onde foi adicionado o redutor.

Tabela 18 - Concentrações de VOCs totais ao longo do monitoramento

\begin{tabular}{|c|c|c|c|c|c|c|c|c|}
\hline \multirow{3}{*}{\multicolumn{2}{|c|}{$\begin{array}{c}\text { Poço } \\
\text { (Localização) }\end{array}$}} & \multicolumn{5}{|c|}{ VOCs Totais $(\mu \mathrm{g} / \mathrm{L})$} & \multicolumn{2}{|c|}{ Decréscimo (\%) } \\
\hline & & \multirow{2}{*}{$\begin{array}{l}\text { Caract. } \\
\text { inicial } \\
\text { mar } 07\end{array}$} & \multicolumn{4}{|c|}{ Monitoramento de desempenho } & \multirow{2}{*}{$\begin{array}{l}\text { Caract. } \\
\text { Inicial ao } \\
\text { mês } 11\end{array}$} & \multirow{2}{*}{$\begin{array}{c}\text { mês } 1 \text { ao } \\
\text { mês } 11\end{array}$} \\
\hline & & & 1 mês & 3 meses & 6 meses & 11 meses & & \\
\hline \multicolumn{9}{|c|}{ Poços de montante mais distantes } \\
\hline MW-22 & Montante & 1843,70 & 1670,10 & 177,80 & 1614,40 & 1028,30 & $44,2 \%$ & $38,4 \%$ \\
\hline MW-23 & Montante & 3512,70 & 7462,70 & 2478,90 & 6931,70 & 5575,10 & $-58,7 \%$ & $25,3 \%$ \\
\hline \multicolumn{9}{|c|}{ Conjunto RW-02 } \\
\hline MW-13 & Montante & 942,70 & 1523,20 & 353,20 & 1229,10 & 937,30 & $0,6 \%$ & $38,5 \%$ \\
\hline RW-02 & Injeção & 460,20 & 5778,60 & 1680,30 & 2577,00 & 2702,70 & $-487,3 \%$ & $53,2 \%$ \\
\hline MW-301 & Jusante & 464,90 & 3035,50 & 792,30 & 724,80 & 956,10 & $-105,7 \%$ & $68,5 \%$ \\
\hline MW-302 & Jusante & 1134,80 & 650,30 & 293,40 & 752,50 & 520,70 & $54,1 \%$ & $19,9 \%$ \\
\hline MW-303 & Jusante & 2816,00 & 1519,90 & 2255,70 & 1379,50 & 830,60 & $70,5 \%$ & $45,4 \%$ \\
\hline \multicolumn{9}{|c|}{ Conjunto RW-04 } \\
\hline MW-14 & Montante & 3378,70 & 2388,60 & 1550,70 & 4802,30 & 2240,10 & $33,7 \%$ & $6,2 \%$ \\
\hline RW-04 & Injeção & 3658,30 & 1116,80 & 859,30 & 3596,30 & 1563,40 & $57,3 \%$ & $-40,0 \%$ \\
\hline MW-304 & Jusante & 4169,90 & 5779,50 & 2005,30 & 4685,70 & 3570,30 & $14,4 \%$ & $38,2 \%$ \\
\hline MW-305 & Jusante & 4945,10 & 7757,70 & 2631,60 & 3510,20 & 6263,80 & $-26,7 \%$ & $19,3 \%$ \\
\hline MW-306 & Jusante & 3286,10 & 5221,10 & 1450,20 & 5114,50 & 5278,10 & $-60,6 \%$ & $-1,1 \%$ \\
\hline \multicolumn{9}{|c|}{ Média de VOCs Totais ( $\mu \mathrm{g} / \mathrm{L})$} \\
\hline \multicolumn{2}{|c|}{ Média conjunto RW-02 } & 1163,72 & 2501,50 & 1074,98 & 1332,58 & 1189,48 & $-2,2 \%$ & $52,4 \%$ \\
\hline \multicolumn{2}{|c|}{ Média conjunto RW-04 } & 3887,62 & 4452,74 & 1699,42 & 4341,80 & 3783,14 & $2,7 \%$ & $15,0 \%$ \\
\hline \multicolumn{2}{|c|}{ Média jusante RW-02 } & 1471,90 & 1735,20 & 1113,80 & 952,30 & 769,10 & $47,7 \%$ & $55,7 \%$ \\
\hline \multicolumn{2}{|c|}{ Média jusante RW-04 } & 4133,70 & 6252,80 & 2029,00 & 4436,80 & 5037,40 & $-21,9 \%$ & $19,4 \%$ \\
\hline
\end{tabular}


Os resultados analíticos podem ser observados integralmente nas Tabelas apresentadas no Anexo 2.

De forma geral, observa-se um comportamento variado com elevação e queda das concentrações em ambas as áreas. Comparando-se com a caracterização inicial, pode se observar um aumento no primeiro mês após a injeção na maioria dos poços envolvidos no teste. Na seqüência, após três meses ocorre mudança no comportamento das concentrações com uma relativa queda observada na maioria dos poços envolvidos. Esse comportamento de queda logo é contrastado com um novo aumento das concentrações referente à seis meses após a injeção. Entre seis e onze meses ocorre uma aparente estabilização. Os valores de decréscimo apresentados, referentes à comparação dos dados do último monitoramento (onze meses após a injeção) com a caracterização inicial e um mês após a injeção, mostram que houve comportamentos distintos associados a diferentes poços. Embora a variação tenha sido mais irregular na comparação com os dados da caracterização inicial, pode se observar uma maior tendência de decréscimo quando se comparam os dados com os valores após um mês de injeção. Ainda sim, os valores não indicam uma queda substancial das concentrações, pois apesar da variação observada entre a caracterização inicial e três meses após a injeção, a última campanha de amostragem (onze meses após a injeção) ainda apresentou valores altos, próximos à mesma ordem de grandeza.

\subsubsection{Demais PARÂMETROS ANALISAdOS}

Além da análise dos compostos orgânicos clorados, outros parâmetros foram analisados no laboratório com a função de avaliar a ocorrência das reações relativas ao método adotado.

\section{Ferro Dissolvido e Sulfato}

Dentre estes parâmetros, o ferro bivalente e o sulfato apresentam uma relação mais direta, visto que esses são produtos da reação esperada. A Tabela 19 mostra um resumo dos valores de ferro dissolvido (ferro bivalente) junto aos valores de sulfato obtidos ao longo dos monitoramentos.

Quanto ao ferro dissolvido pode-se observar que, de maneira geral, não houve grandes mudanças para a maioria dos poços até a amostragem do sexto mês após a injeção. Porém, na amostragem de onze meses após a injeção se nota um substancial aumento de ferro dissolvido em parte dos poços da área do teste. Esses, que apresentam tal comportamento, parecem na maior parte coincidir com os poços que obtiveram maiores variações dos parâmetros físico-químicos.

Assim, exceto pelos próprios poços de injeção (RW-02 e RW-04), pode se notar a alteração nos poços de montante próximos à área de injeção (MW-13 e MW-14), nos poços 
MW-301 ao MW-303 localizados a jusante do ponto de injeção RW-02 e também no poço MW-306, a jusante do ponto de injeção RW-04.

Quanto ao sulfato, pode se observar um comportamento diferente em relação ao ferro dissolvido, visto que comparado à caracterização inicial a maioria dos poços apresentou aumento substancial de concentrações já no primeiro mês do monitoramento de desempenho.

Tabela 19 - Valores de ferro bivalente dissolvido e sulfato ao longo do monitoramento

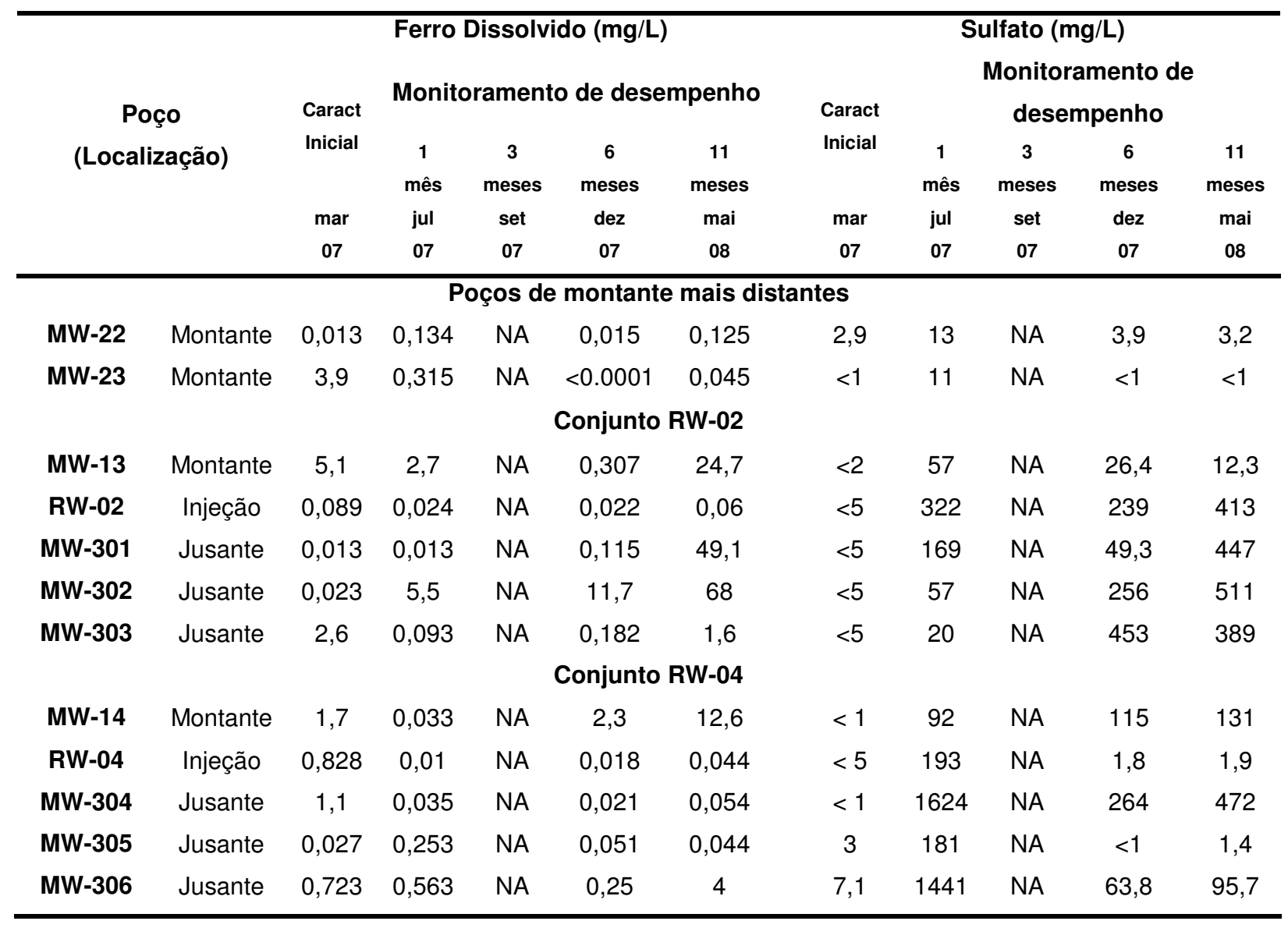

\section{Alcalinidade e RedEq}

Os dados de alcalinidade total e RedEq são sumarizados na Tabela 20. Os dados apresentam alta variabilidade, de modo que se torna difícil a possibilidade de uma melhor correlação. Ainda sim, podem ser apontados alguns fatores, como no caso do aumento de valores de alcalinidade observados no primeiro mês após a injeção na maioria dos poços relacionados ao poço de injeção RW-02. Nestes mesmos poços pode ser notado o decréscimo do mesmo parâmetro até a última campanha, onze meses após a injeção do produto. 
Já os valores de RedEq, de forma geral, indicam para aqueles poços onde ocorreram variações dos demais parâmetros, um aumento da capacidade redutiva do meio já no primeiro mês pós injeção com tendência de queda observada até a última amostragem.

Tabela 20 - Valores de alcalinidade e RedEq ao longo do monitoramento

\begin{tabular}{|c|c|c|c|c|c|c|c|c|c|c|c|}
\hline \multirow{3}{*}{\multicolumn{2}{|c|}{$\begin{array}{c}\text { Poço } \\
\text { (Localização) }\end{array}$}} & \multicolumn{5}{|c|}{ Alcalinidade Total (mg/L) } & \multicolumn{5}{|c|}{$\operatorname{RedEq}(\mathrm{mg} / \mathrm{L})$} \\
\hline & & \multirow{3}{*}{$\begin{array}{c}\text { Caract } \\
\text { Inicial } \\
\text { mar } \\
07\end{array}$} & \multicolumn{4}{|c|}{$\begin{array}{c}\text { Monitoramento de } \\
\text { desempenho }\end{array}$} & \multirow{3}{*}{$\begin{array}{c}\text { Caract } \\
\text { Inicial } \\
\text { mar } \\
07\end{array}$} & \multicolumn{4}{|c|}{$\begin{array}{c}\text { Monitoramento de } \\
\text { desempenho }\end{array}$} \\
\hline & & & \multirow{2}{*}{$\begin{array}{c}1 \\
\text { mês } \\
\text { jul } \\
07\end{array}$} & \multirow{4}{*}{$\begin{array}{c}3 \\
\text { mês } \\
\text { set } \\
07 \\
\text { de } \mathrm{m}\end{array}$} & \multirow{3}{*}{$\begin{array}{c}6 \\
\text { meses } \\
\text { dez } \\
07\end{array}$} & \multirow{2}{*}{$\begin{array}{c}11 \\
\text { meses } \\
\text { mai } \\
08\end{array}$} & & \multirow{4}{*}{$\begin{array}{c}1 \\
\text { mês } \\
\text { jul } \\
07\end{array}$} & \multirow{3}{*}{$\begin{array}{c}3 \\
\text { meses } \\
\text { set } \\
07\end{array}$} & \multirow{4}{*}{$\begin{array}{c}6 \\
\text { meses } \\
\operatorname{dez} \\
07\end{array}$} & \multirow{3}{*}{$\begin{array}{c}11 \\
\text { meses } \\
\text { mai } \\
08\end{array}$} \\
\hline & & & & & & & & & & & \\
\hline \multirow{2}{*}{\multicolumn{9}{|c|}{ Poços de montante mais distantes }} & & & \\
\hline & & & & & & & & & & & \\
\hline MW-22 & Montante & 28 & 6,6 & NA & $<5$ & 10 & 3,1 & 2,2 & 2,6 & 2,2 & $<1$ \\
\hline MW-23 & Montante & 23 & 13 & NA & 17 & 9 & 5,2 & $<1$ & 11 & 8,4 & 2,2 \\
\hline \multicolumn{12}{|c|}{ Conjunto RW-02 } \\
\hline MW-13 & Montante & 11 & 90 & NA & 20 & $<5$ & 3,1 & 7,2 & 1,6 & 11 & 1,5 \\
\hline RW-02 & Injeção & $<5$ & 1200 & NA & 218 & 48 & 2,5 & 1117 & 228 & 252 & 7,5 \\
\hline MW-301 & Jusante & 125 & 96 & NA & 69 & 15 & 2 & 235 & 2,2 & 55 & 1 \\
\hline MW-302 & Jusante & 271 & 580 & NA & 5 & $<5$ & 5 & 55,3 & 11 & 213 & 1,2 \\
\hline MW-303 & Jusante & 161 & 2000 & NA & 148 & 35 & 2,9 & 390 & 55 & 129 & 1 \\
\hline \multicolumn{12}{|c|}{ Conjunto RW-04 } \\
\hline MW-14 & Montante & 11 & 45 & NA & $<5$ & $<5$ & 3,2 & 201 & 16 & 34 & $<1$ \\
\hline RW-04 & Injeção & 62 & 4300 & NA & 65 & 143 & 3,6 & 54 & 150 & 387 & 1,3 \\
\hline MW-304 & Jusante & 316 & 6,2 & NA & 10 & 16 & 9 & $<1$ & 2,7 & 4,1 & 1,5 \\
\hline MW-305 & Jusante & 273 & 33 & NA & 73 & 23 & 10 & $<2$ & 2,3 & 6,2 & 1,2 \\
\hline MW-306 & Jusante & 318 & 42 & NA & 79 & 30 & 6,5 & 110 & 16 & 62 & $<1$ \\
\hline
\end{tabular}

\subsection{INTERPRETAÇÃo dos RESULTADOS DO TESTE PILOTO UTILIZANDO ISCR}

Com base em todos os resultados apresentados até o momento, foi possível avaliar as duas áreas de injeção (conjunto do RW-02 e conjunto do RW-04), como apresentado a seguir.

\section{Análise inicial do conjunto RW-02}

A Figura 17 resume parte dos resultados obtidos no conjunto de poços associados ao poço de injeção RW-02. Nota-se, claramente, que nenhum dos parâmetros sofre alteração significativa nos poços de montante mais distantes (MW-22 e MW-23). Sendo assim, estes podem ser tomados como referência na comparação com as alterações sofridas nos demais poços devido a potencial presença do polisulfeto de cálcio. 
Tanto os dados de $\mathrm{pH}$ quanto os dados de potencial de oxi-redução indicam a presença do produto nos poços, uma vez que este apresenta características alcalinas e redutoras.

Dentre os demais poços do conjunto, ambos os parâmetros parecem sofrer alterações tanto no poço de injeção (RW-02) e seu poço de montante mais próximo (MW13), quanto em dois dos poços de jusante (MW-301 e MW-302).
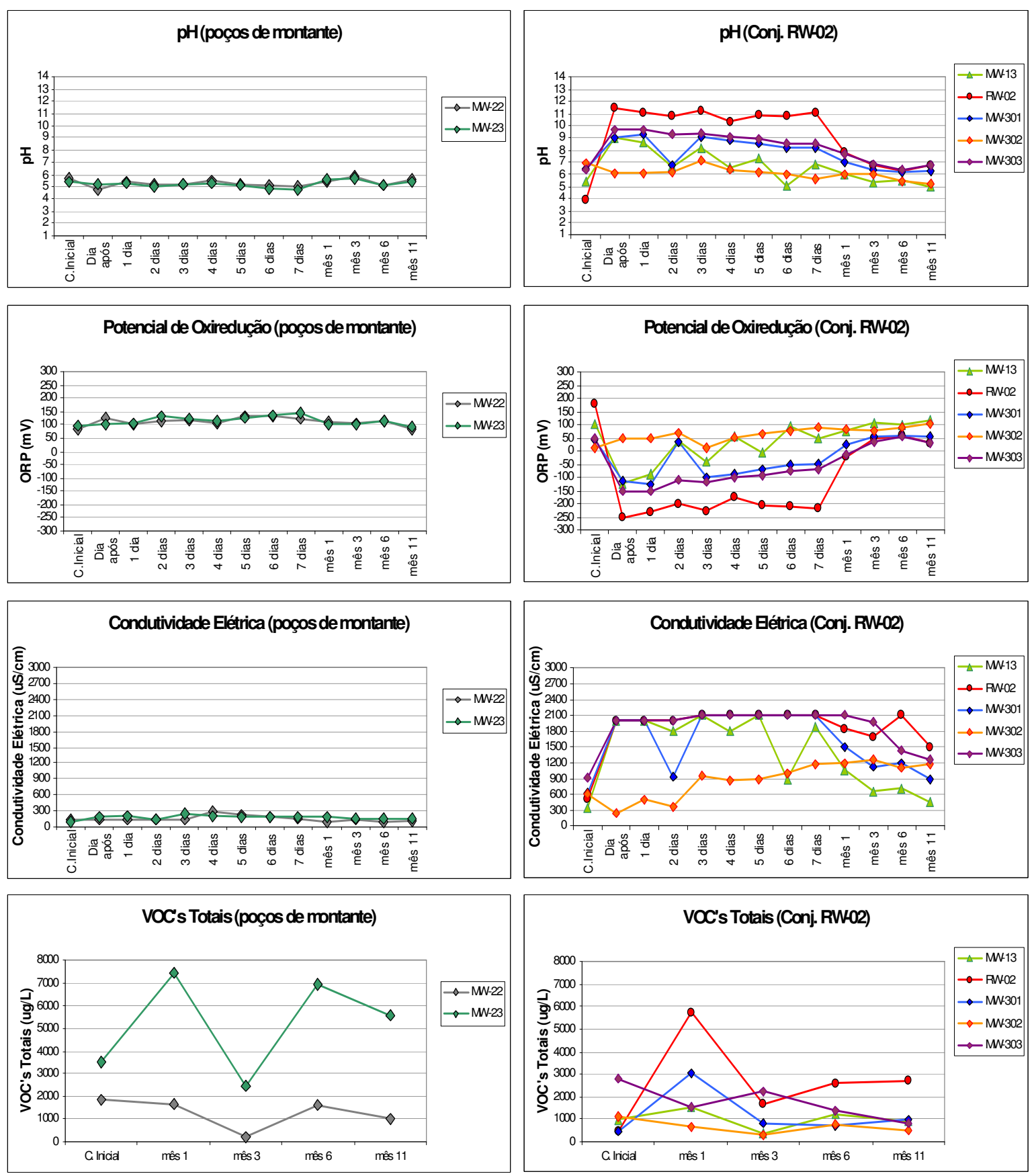

Figura 17 - Comparação dos parâmetros analisados ao longo dos monitoramentos (Conj. $\mathrm{RW}-02)$ 
As alterações são mais significativas ao longo do monitoramento inicial (no dia após a injeção e ao longo de sete dias), de modo que se percebe uma tendência de estabilização logo no primeiro mês até o final dos monitoramentos, em onze meses após a injeção. Dessa forma, é assumido que houve acesso do produto aos poços, embora não se possa quantificar se o mesmo atuou na redução dos contaminantes.

Já os dados de condutividade elétrica poderiam indicar entre outras coisas, a ocorrência da reação esperada, uma vez que esta tende a liberar íons no meio. Aqui também se nota o padrão de variação, tal qual ocorre nos parâmetros de $\mathrm{pH}$ e potencial de oxi-redução, com destaque para o poço MW-302 que apesar de não variar significativamente ao longo do monitoramento inicial após a injeção, apresenta gradual aumento até a última atividade de amostragem.

Quanto aos dados de VOC totais, observa-se que quando comparados aos poços que não tiveram acesso ao produto (MW-22 e MW-23), os poços do conjunto do RW-02 apresentam comportamento relativamente similar no período entre a caracterização inicial e o terceiro mês após a injeção. A partir desse ponto, observa-se que os poços do conjunto apresentaram comportamento mais linear até o final da amostragem, embora se possa notar diminuição nas concentrações de VOCs no poço MW-303, quando comparados os resultados da caracterização inicial e de onze meses após a injeção.

Dadas as variações, até os resultados do último monitoramento, não foi possível observar com clareza se houve abatimento da massa de contaminantes em função da ação do produto, mesmo sendo claro que este teve acesso aos poços do conjunto.

\section{Análise inicial do conjunto RW-04}

A Figura 18 resume parte dos resultados obtidos no conjunto de poços associados ao poço de injeção RW-04. Da mesma forma que o conjunto de poços do RW-02, os poços a montante, mais distantes, foram utilizados para efeito de comparação, uma vez que não sofreram os efeitos do produto injetado.

Quando comparados aos dados dos poços de montante, mais distantes, apenas o poço de injeção (RW-04) e seu poço de montante mais próximo (MW-14) apresentaram os efeitos da presença do produto. Estes efeitos podem ser observados na variação tanto nos parâmetros de $\mathrm{pH}$ e potencial de oxi-redução, quanto na condutividade elétrica. Nota-se nesses poços a mudança do comportamento dos parâmetros logo no monitoramento inicial da reação, porém apenas o RW-04 sustenta as alterações por mais tempo ao longo do monitoramento de desempenho. Este comportamento indica a retenção do produto por mais tempo no poço de injeção, e também a restrição do acesso ao produto nos demais poços a jusante. Essa retenção pode estar associada à heterogeneidades locais do aquífero.

Dessa forma, os dados de VOC podem não ser representativos ao propósito da comparação da presença do produto com o abatimento da massa de contaminantes, uma 
vez que para a maior parte desses poços não houve acesso do produto. Mesmo para os poços RW-04 e MW-14 onde o produto encontrava-se presente, não se notou abatimento expressivo da massa de contaminantes quando comparado com a caracterização inicial.
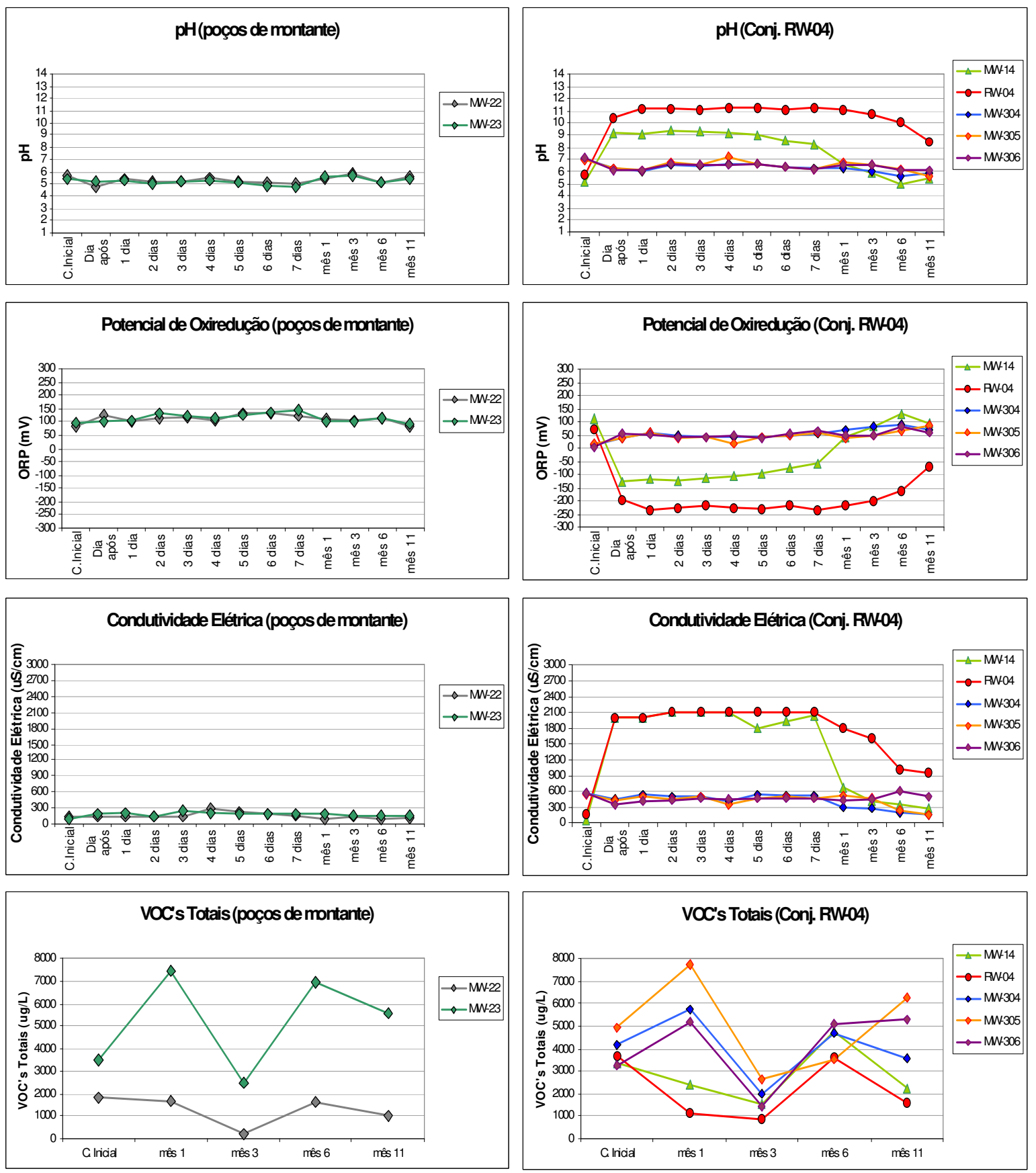

Figura 18 - Comparação dos parâmetros analisados ao longo dos monitoramentos (Conj. RW-04)

Dadas as comparações iniciais, serão apresentadas a seguir análises pontuais referentes ao conjunto de poços associados ao poço de injeção RW-02, visto que este 
apresentou melhor dispersão do produto injetado.

\section{Análise dos Principais Compostos no Conjunto RW-02}

A Figura 19 apresenta o comportamento das concentrações dos principais compostos orgânicos clorados para cada poço do conjunto do ponto RW-02, assim como também as médias de todos os poços do conjunto e dos poços a jusante.
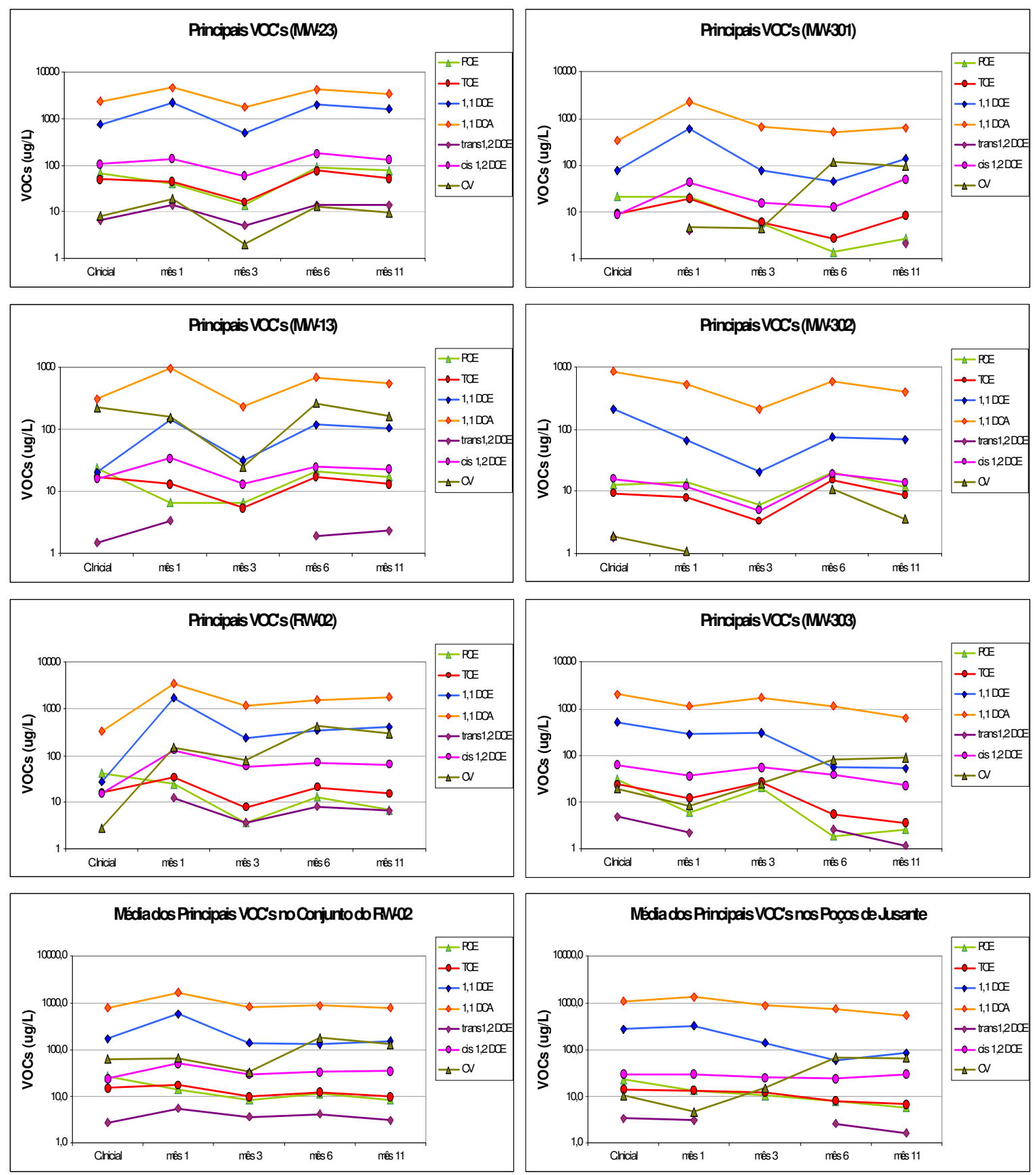

Figura 19 - Principais compostos obtidos ao longo dos monitoramentos (conj. RW-02)

Observa-se que as maiores concentrações estão relacionadas aos compostos 1,1-DCA e 1,1-DCE, e que as mesmas não apresentam queda expressiva ao longo dos 
monitoramentos. Apesar das variações das concentrações, não se notam quedas seqüenciais que pudessem indicar a atuação efetiva do produto.

Mesmo os compostos que apresentaram queda quando comparados à caracterização inicial, não mostram abatimento substancial de massa quando comparados aos resultados obtidos no ambiente controlado dos testes de tratabilidade, apontados no ítem 6.1 deste relatório.

Outro fator importante a ser observado é o aumento da concentração do composto cloreto de vinila ao longo dos monitoramentos. De acordo com as reações esperadas, este composto não deveria ser formado, uma vez que o método se utilizaria da eliminação de dois cloretos de forma conjunta, evitando a degradação seqüencial para espécies mais nocivas. Apesar de ser observada a diminuição das concentrações de 1,1-DCE, não se pode afirmar que o cloreto de vinila tenha se formado a partir da degradação desse composto, ou que o aumento de sua concentração seja mais resultado de alterações físicoquímicas do aquífero devido à presença pouco eficiente do redutor injetado.

\section{Análise dos parâmetros ferro dissolvido e sulfato no conjunto RW-02}

A Figura 20 mostra a evolução das concentrações de ferro bivalente dissolvido e sulfato, dada a relação direta desses parâmetros com reação esperada ilustrada no ítem 4.2.2.1.

Nota-se que tanto para o poço de injeção RW-02, quanto para os poços de jusante (MW-301 ao MW-303), as concentrações de sulfato tendem a sofrer alterações antes da elevação das concentrações de ferro bivalente dissolvido. Esse fato pode indicar que para esses pontos, outras reações podem estar ocorrendo de modo a consumir o produto sem necessariamente produzir ferro bivalente dissolvido. Entre as possíveis reações paralelas, pode se destacar a seguinte (equação 18):

$$
2 \mathrm{CaS}_{5}+4 \mathrm{O}_{2} \rightarrow 2 \mathrm{CaSO}_{4}+\mathrm{S}_{8}
$$

A reação com oxigênio dissolvido pode ser considerada, visto que parte da mistura do produto foi realizada com água provinda do sistema público, uma vez que o bombeamento dos poços da área não se mostrou suficiente. Diferentemente da água do aquífero, a água do sistema público pode ter apresentado concentrações de oxigênio dissolvido suficientes para que a reação paralela citada anteriormente tenha produzido sulfato sem aumentar a concentração de ferro bivalente dissolvido.

Outra possibilidade de reação paralela pode estar relacionada à formação do sulfeto de ferro a partir do consumo do ferro reduzido (bivalente) e polisulfeto, como ilustrado a seguir (equação 19):

$$
2 \mathrm{~S}_{5}^{-2}+2 \mathrm{Fe}^{+2} \rightarrow 2 \mathrm{FeS}+\mathrm{S}_{8}
$$



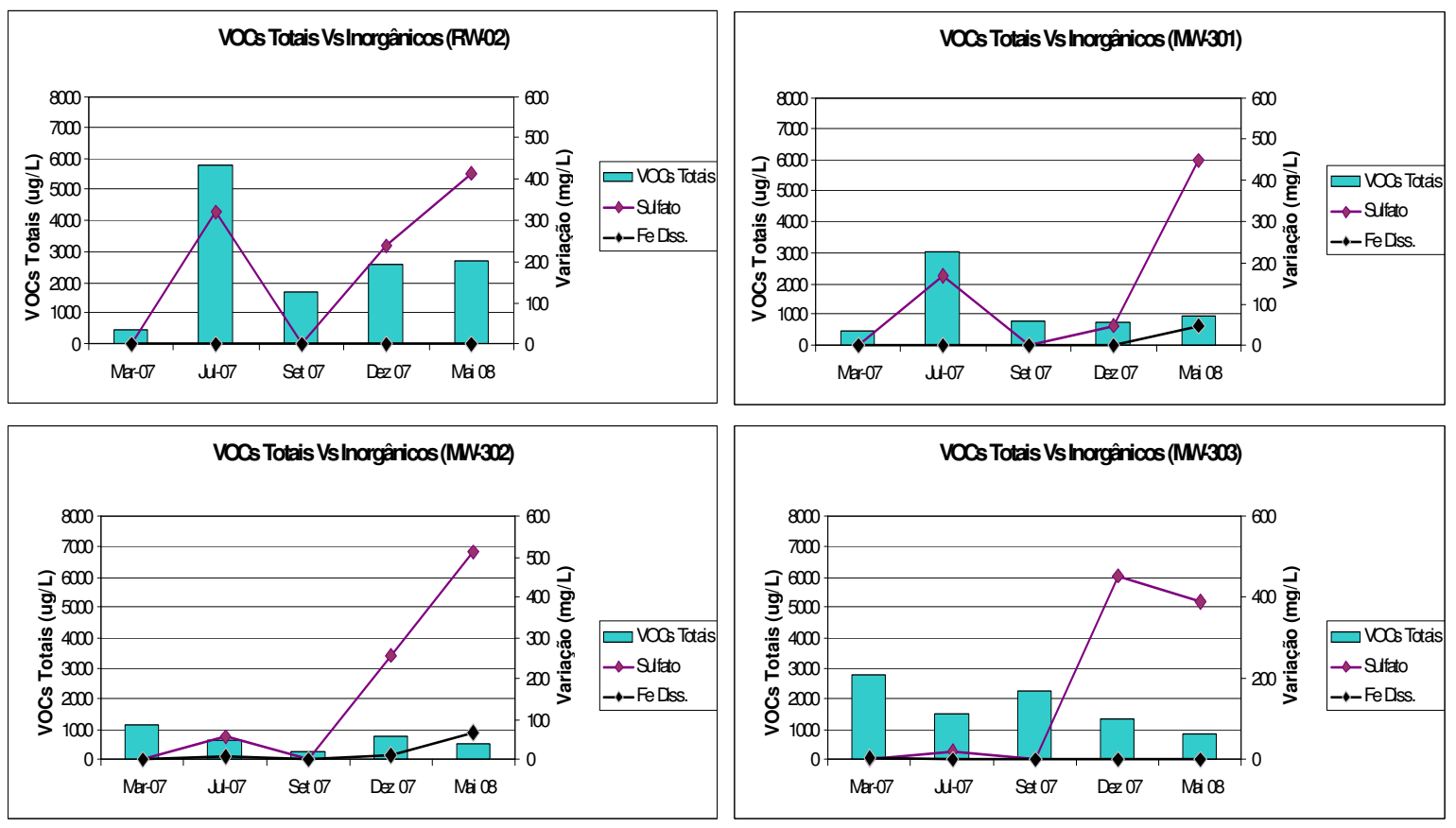

Figura 20 - Comparação das concentrações de ferro dissolvido e sulfato ao longo dos monitoramentos

Embora a possibilidade de reações paralelas mereça ser considerada, o aparecimento do ferro bivalente dissolvido foi observado de forma mais consistente apenas na última etapa de monitoramento (onze meses após a injeção). Porém, ainda que presente, o ferro bivalente dissolvido não aparenta ter reagido de forma efetiva na degradação dos contaminantes durante as etapas dos monitoramentos considerados.

A Tabela 21 apresenta as proporções molares entre o ferro bivalente dissolvido e o 1,1-DCA, contaminante de maior concentração entre os compostos de interesse.

Observa-se que quando presente em proporções maiores, o ferro bivalente dissolvido parece não ter sido efetivo na degradação dos compostos orgânicos voláteis. Dessa forma, é possível inferir que a reação esperada não aconteça similarmente ao que foi observado nos testes de tratabilidade, onde quase todo o contaminante foi degradado em cerca de 120 dias (ítem 6.1). 
Tabela 21 - Proporção molar de ferro bivalente dissolvido e 1,1-DCA comparado à VOCs totais

\begin{tabular}{|c|c|c|c|c|}
\hline \multicolumn{5}{|c|}{ MW-301 } \\
\hline \multicolumn{2}{|c|}{$(\mu \mathrm{mol} / \mathrm{L})$} & \multicolumn{2}{|c|}{ Proporção molar } & \multirow{2}{*}{$\frac{(\mu \mathrm{gl} / \mathrm{L})}{\text { VOCs Totais }}$} \\
\hline Fe Diss. & 1,1DCA & Fe Diss. & 1,1 DCA & \\
\hline 0,23 & 3,37 & 0,07 & 1 & 464,90 \\
\hline 0,23 & 22,93 & 0,01 & 1 & 3035,50 \\
\hline NA & 6,67 & NA & 1 & 792,30 \\
\hline 2,06 & 5,33 & 0,39 & 1 & 724,80 \\
\hline 879,93 & 6,34 & 138,71 & 1 & 956,10 \\
\hline \multicolumn{5}{|c|}{ MW-302 } \\
\hline \multicolumn{2}{|c|}{$(\mu \mathrm{mol} / \mathrm{L})$} & \multicolumn{2}{|c|}{ Proporção molar } & $(\mu \mathrm{gl} / \mathrm{L})$ \\
\hline Fe Diss. & $1,1 \mathrm{DCA}$ & Fe Diss. & $1,1 \mathrm{DCA}$ & VOCs Totais \\
\hline 0,41 & 8,59 & 0,05 & 1 & 1134,80 \\
\hline 98,57 & 5,37 & 18,34 & 1 & 650,30 \\
\hline NA & 2,10 & NA & 1 & 293,40 \\
\hline 209,68 & 5,94 & 35,30 & 1 & 752,50 \\
\hline 1218,64 & 3,99 & 305,43 & 1 & 520,70 \\
\hline \multicolumn{5}{|c|}{ MW-303 } \\
\hline \multicolumn{2}{|c|}{$(\mu \mathrm{mol} / \mathrm{L})$} & \multicolumn{2}{|c|}{ Proporção molar } & $(\mu \mathrm{gl} / \mathrm{L})$ \\
\hline Fe Diss. & 1,1DCA & Fe Diss. & $1,1 \mathrm{DCA}$ & VOCs Totais \\
\hline 46,59 & 20,67 & 2,25 & 1 & 2816,00 \\
\hline 1,67 & 11,31 & 0,15 & 1 & 1519,90 \\
\hline NA & 18,02 & NA & 1 & 2255,70 \\
\hline 3,26 & 11,52 & 0,28 & 1 & 1379,50 \\
\hline 28,67 & 6,34 & 4,52 & 1 & 830,60 \\
\hline
\end{tabular}

\section{APLICAÇÃO DA OXIDAÇÃO QUÍMICA IN SITU COM PERMANGANATO DE POTÁSSIO PARA REMEDIAÇÃO DE ÁREA CONTAMINADA POR SOLVENTES CLORADOS}

\subsection{RESUMO}

A oxidação química in situ é uma metodologia de remediação química que vem sendo empregada em áreas contaminadas de forma mais intensa, por ser um processo que apresenta grande eficiência na redução da massa de contaminante (particularmente etenos clorados) em um curto período de tempo. Este artigo apresenta os resultados da oxidação química, com injeção de permanganato de potássio, empregada como alternativa de remediação em uma área impactada por compostos organoclorados, com o objetivo de avaliar a eficiência do oxidante em diminuir as concentrações dos contaminantes presentes 
na água subterrânea na fase dissolvida, bem como o comportamento do aquífero frente àos possíveis efeitos geoquímicos colaterais.

O contato do oxidante foi considerado efetivo em abranger as plumas de compostos orgânicos voláteis presentes no aquífero freático, visto que após vinte e dois meses das atividades de injeção, apenas um ponto apresentou concentração de 1,1-DCE acima da meta de remediação estabelecida, primeiramente, para a área. Salienta-se que após a iniciação das atividades relacionadas à remediação da área, tal composto sofreu alterações em suas características toxicológicas, estabelecidas pela Agência de Proteção Ambiental dos Estados Unidos, passando a ser considerado como contaminante não carcinogênico. Com esta informação, um novo cálculo de meta de remediação foi realizado. Assim, considerando este novo valor, todos os poços de monitoramento apresentaram com concentrações de 1,1-DCE inferiores ao novo valor obtido.

Embora tenham sido observadas concentrações de metais dissolvidos acima dos limites estabelecidos pelo órgão ambiental no último monitoramento realizado, espera-se que tais valores comecem a ser reduzidos e retornem aos níveis presentes naturalmente no aquífero, anteriormente à injeção do oxidante, uma vez que o consumo do oxidante seja total.

\subsection{INTRODUÇÃO}

A alta eficiência como desengraxante, fez com que os solventes clorados fossem, desde o início de sua fabricação, utilizados em diversos segmentos industriais, mas apenas no final da década de 1960, que estes compostos começaram a ser apontados como um dos principais causadores de contaminação em subsuperfície. Quando presentes na água subterrânea, mesmo em baixas concentrações, fazem com que a mesma se torne imprópria para consumo, trazendo potencial risco à saúde humana e ao meio ambiente (Pankow e Cherry, 1996).

Embora os contaminantes organoclorados possam ser degradados naturalmente, devido à ação de microorganismos presentes em subsuperfície, o tempo necessário para que isto ocorra pode tornar este processo inviável e resultar ainda, no acúmulo de VC, composto de elevada toxicidade (Suthersan e Payne, 2005). Assim, processos de degradação de natureza química abiótica, geralmente tendem a ser mais viáveis e mais adequados para a reabilitação de uma área impactada, de forma que potenciais riscos possam ser anulados ou gerenciados de maneira mais eficiente.

A oxidação química in situ vem sendo empregada em áreas contaminadas de forma mais intensa, ao invés de outras metodologias de remediação (como bombeamento e tratamento da água subterrânea, atenuação natural ou biológico) por ser um processo que 
apresenta eficiência na redução da massa de contaminante (particularmente etenos clorados) em um curto período de tempo (Suthersan e Payne, 2005).

Este artigo objetiva apresentar os resultados da ISCO a partir do uso de permanganato de potássio como agente oxidante, em uma área industrial contaminada por compostos orgânicos voláteis, sendo o composto 1,1-DCE o principal alvo. No processo de remediação química da área, procurou-se dar especial atenção aos seguintes assuntos: 1) se houve contato do contaminante com o oxidante aplicado em toda a área e profundidade da pluma de contaminação; 2) se a quantidade de oxidante foi suficiente para destruir os contaminantes até a meta de remediação; e 3) se houve algum efeito geoquímico colateral indesejável no aquífero com a injeção. O composto oxidante foi injetado em um aquífero freático relativamente homogêneo situado num contexto geológico de manto de intemperismo desenvolvido sobre rochas sedimentares do membro inferior da Formação Tatuí.

Uma vez introduzidos na zona saturada, oxidantes químicos tendem a abranger toda a área alvo, principalmente através de processos como advecção e dispersão. No entanto, durante a percolação do oxidante, pode ocorrer a perda do mesmo devido à reações químicas em subsuperfície com compostos presentes naturalmente no solo. Isto é uma importante consideração, já que a demanda de oxidante natural pode inviabilizar, economicamente, a aplicação da oxidação química (USEPA, 2004).

Como os processos de advecção e dispersão são fundamentais para o aumento da eficiência do permanganato de potássio como agente oxidante em alcançar o contaminante presente nas fases dissolvidas e adsorvidas, é importante que o aquífero possua características, como: 1) altas permeabilidade efetiva e velocidade da água subterrânea isso permite que o oxidante alcance áreas maiores de contato com o contaminante; 2) homogeneidade - em solos heterogêneos, a eficiência do oxidante em entrar em contato com o contaminante pode ser comprometida por não haver distribuição uniforme do fluido; 3) baixa concentração de compostos inorgânicos oxidáveis - a presença de compostos oxidáveis como ferro e outros metais formam precipitados o que poderiam reduzir significativamente a permeabilidade efetiva intrínseca da zona saturada (USEPA, 2004) e competir com o contaminante no processo de oxidação; e 4) baixo índice de carbono orgânico - a presença de carbono orgânico pode consumir parte importante do agente injetado e tornar a alternativa economicamente inviável (Suthersan e Payne, 2005).

Entre as principais vantagens para a aplicação da ISCR como metodologia de remediação, tem-se: 1) assim que injetado, o $\mathrm{KMnO}_{4}$ está prontamente disponível para a reação com os contaminantes e resulta na geração de materiais inócuos como dióxido de carbono, precipitado de dióxido de manganês, potássio e cloreto; 2) o processo é facilmente aplicado e controlado; 3) os tempos de tratamento e reação são rápidos; 4) não há geração 
de resíduo (DOE, 1999).

Ainda como vantagens podem ser apontadas a rápida e intensa reação dos agentes oxidantes na diminuição das concentrações dos contaminantes (incluindo compostos biorecalcitrantes) e a facilidade de uso e adaptação de equipamentos e materiais que compõem o sistema, são algumas das vantagens desta tecnologia (Crimi e Siegrist, 2003).

Como desvantagens, podem ser citadas: as alterações na geoquímica e permeabilidade do aquífero devido à precipitação de sólidos de dióxido de manganês $\left(\mathrm{MnO}_{2}\right)$ (Hu e Chou, 2002). Resultados de trabalhos já realizados apontam também para a possibilidade de mobilização de metais como cromo, arsênio, selênio e mercúrio durante o período de tratamento, presentes no solo na fase adsorvida (Marvin; Chambers; Leavitt, 2002).

\subsection{A OXIDAÇÃO QUÍMICA IN SITU}

A oxidação química deve ser predominantemente utilizada como alternativa de remediação, quando os contaminantes organoclorados estão presentes no solo saturado ou franja capilar, nas fases dissolvida e adsorvida. Em locais onde é necessário o tratamento de área fonte na zona não saturada, o mais indicado é que outra tecnologia de remediação seja requerida, como por exemplo, a extração de vapores do solo. Na existência de produto em fase livre, outras tecnologias de remediação precisam ser conduzidas anteriormente à oxidação química para que a remediação seja segura e o custo viável (USEPA, 2008).

Aplicações adequadas da oxidação química implicam em resultados mais rápidos e de custos mais atrativos na reabilitação de uma área contaminada por compostos organoclorados do que alternativas que envolvam bombeamento e tratamento da água contaminada, ou mesmo a atenuação natural. Diversos oxidantes podem ser utilizados nesta alternativa de remediação, os principais são: 1) permanganato de potássio; 2) permanganato de sódio; 3) peróxido de hidrogênio; 4) persulfato; e 5) ozônio.

$\mathrm{O} \mathrm{KMnO}_{4}$ é um sal cristalino fino que pode ser dissolvido em campo, criando soluções de concentração de até $6 \%$, em temperatura ambiente de $20^{\circ} \mathrm{C}$. Em temperaturas inferiores, a solubilidade deste oxidante pode diminuir consideravelmente (Suthersan e Payne, 2005).

Devido à baixa reatividade entre o permanganato de potássio e a matriz do aquífero durante as reações de oxidação química, este oxidante pode ser transportado pelos processos advectivo e dispersivo juntamente com o fluxo da água subterrânea e persistir por um período maior de tempo, em relação ao peróxido de hidrogênio e o ozônio, reagindo com os contaminantes orgânicos. Além disso, a presença do $\mathrm{KMnO}_{4}$ no aquífero não produz 
calor ou gases (Marvin, Chambers e Leavitt, 2002).

As reações entre o $\mathrm{KMnO}_{4}$ e os solventes organoclorados, PCE, TCE, DCE e VC, são apresentadas, respectivamente, pelas equações (20) a (23), conforme Crimi e Siegrist (2003):

$$
\begin{aligned}
& 4 \mathrm{KMnO}_{4}+3 \mathrm{C}_{2} \mathrm{Cl}_{4}+4 \mathrm{H}_{2} \mathrm{O} \rightarrow 6 \mathrm{CO}_{2}+4 \mathrm{MnO}_{2}+4 \mathrm{~K}^{+}+8 \mathrm{H}^{+}+12 \mathrm{Cl}^{-} \\
& 2 \mathrm{KMnO}_{4}+\mathrm{C}_{2} \mathrm{HCl}_{3} \rightarrow 2 \mathrm{CO}_{2}+2 \mathrm{MnO}_{2}+2 \mathrm{~K}^{+}+\mathrm{H}^{+}+3 \mathrm{Cl}^{-} \\
& 8 \mathrm{KMnO}_{4}+3 \mathrm{C}_{2} \mathrm{H}_{2} \mathrm{Cl}_{2} \rightarrow 6 \mathrm{CO}_{2}+8 \mathrm{MnO}_{2}+8 \mathrm{~K}^{+}+6 \mathrm{Cl}^{-}+2 \mathrm{OH}^{-}+2 \mathrm{H}_{2} \mathrm{O} \\
& 10 \mathrm{KMnO}_{4}+3 \mathrm{C}_{2} \mathrm{H}_{3} \mathrm{Cl} \rightarrow 6 \mathrm{CO}_{2}+10 \mathrm{MnO}_{2}+10 \mathrm{~K}^{+}+3 \mathrm{Cl}^{-}+7 \mathrm{OH}^{-}+\mathrm{H}_{2} \mathrm{O}
\end{aligned}
$$

$\mathrm{O}$ ingrediente ativo na oxidação do permanganato de potássio é o íon $\mathrm{MnO}_{4}{ }^{-}$. O átomo de manganês possui valência +7 e é apresentado como $\mathrm{Mn}(\mathrm{VII})$. Durante o processo de oxidação, o manganês é reduzido para valência +4 e é apresentado como Mn(IV). O principal produto da reação com o contaminante é o dióxido de manganês, que precipita da solução (Suthersan e Payne, 2005).

O permanganato tem grande afinidade na oxidação de compostos contendo cadeias de carbono com ligação dupla, grupos dos aldeídos e das hidroxilas. Sob condições normais de $\mathrm{pH}$ e temperatura, a ligação dupla das cadeias de carbono dos alcenos é quebrada espontaneamente e compostos intermediários instáveis são convertidos em dióxido de carbono (Hu e Chou, 2002). Além de dióxido de carbono, são também resultados da reação: sólidos de dióxido de manganês e íons de potássio e manganês (quando compostos halogenados são oxidados). Mas na quantidade gerada, estes compostos, não são tóxicos à saúde humana (DOE, 1999).

Segundo Marvin, Chambers e Leavitt (2002), a taxa de reação de um organoclorado com o $\mathrm{KMnO}_{4}$ na fase dissolvida é dependente das concentrações de ambos os compostos. $\mathrm{O}$ aumento da dosagem do $\mathrm{KMnO}_{4}$ aumentará não somente a oxidação do contaminante, mas também o consumo do permanganato. Mas a diminuição na concentração do $\mathrm{KMnO}_{4}$ poderá diminuir a cinética das reações, causando a coexistência entre o contaminante e o agente oxidante, o que diminuiria a efetividade da oxidação química.

A avaliação correta da dosagem de $\mathrm{KMnO}_{4}$ é o primeiro passo para a escolha desta alternativa como tratamento de um meio contaminado por compostos organoclorados e é obtida pela demanda de oxidante no solo ou demanda natural de oxidante. O SOD ou NOD é a quantidade de oxidante consumido por unidade de massa sólida do aquífero em determinado tempo. A eficácia da oxidação de contaminantes organoclorados até sua completa mineralização é inversamente proporcional à presença natural de matéria 
orgânica, ferro ferroso $\left(\mathrm{Fe}^{2++}\right)$ ou outros metais reduzidos no solo. Isto porque, durante o processo de oxidação, não há diferenciação do permanganato de potássio entre os contaminantes e os compostos orgânicos e inorgânicos oxidáveis presentes naturalmente no solo (Hønning, 2007).

Em muitos casos, o $\mathrm{KMnO}_{4}$ necessário para a remediação in situ da água subterrânea é controlado mais pelo SOD do que pelas concentrações dos contaminantes presentes. Em geral, solo de granulometria fina com alta porcentagem de carbono orgânico exibe um alto SOD em comparação com a areia grossa (Marvin, Chambers e Leavitt, 2002). Valor muito elevado de SOD pode tornar a alternativa inviável, por implicar numa grande quantidade de permanganato a ser utilizado, já que este oxidará não somente os contaminantes orgânicos, mas também o carbono orgânico e metais reduzidos presente no meio.

Resumidamente, o conhecimento de fatores específicos da área de interesse, fundamental para a seleção desta tecnologia de remediação, envolve: 1) tipo e distribuição dos compostos contaminantes; 2) litologia; 3) SOD; e 4) geoquímica do meio físico. A combinação destas informações e de resultados obtidos por testes em laboratório (para avaliar a eficiência do agente químico de interesse em abater concentrações de contaminantes no solo e água subterrânea impactados) e testes piloto em campo podem fornecer informações quanto aos efeitos secundários como diminuição da permeabilidade, mobilização de metais redox-sensíveis e o potencial reaparecimento dos contaminantes após o tratamento (Marvin, Chambers e Leavitt, 2002).

Devido ao permanganato de potássio sólido ser derivado da extração de minérios, pode haver impurezas em seus cristais comercialmente disponíveis, que incluem sais e traços de metais. Embora a composição deste produto seja irrelevante à reação de oxidação dos contaminantes, pode ser potencialmente relevante em subsuperfície, quando comparada aos padrões e critérios de qualidade da água subterrânea (Crimi e Siegrist, 2003). A Tabela 22 apresenta os metais identificados pela análise química de uma amostra de permanganato de potássio realizada na matriz sólida do oxidante e na solução preparada a $0,5 \%$ (ERM, 2009). A qualidade deste produto pode ser considerada não satisfatória para ser utilizada como agente remediador, por apresentar concentrações de metais, que quando inseridos na água subterrânea poderia ocasionar em valores não aceitáveis de acordo com os padrões ambientais. 
Tabela 22 - Exemplo de concentrações de metais identificadas em amostra de permanganato de potássio que pode ser considerada não ideal para remediação de área contaminada

\begin{tabular}{cccc}
\hline Elemento & $\begin{array}{c}\text { Concentração na } \\
\text { matriz sólida } \\
(\mathbf{m g} / \mathbf{k g})\end{array}$ & $\begin{array}{c}\text { Concentração na } \\
\text { solução à 5\% } \\
(\mathbf{m g} / \mathbf{L})\end{array}$ & $\begin{array}{c}\text { Valor de referência } \\
\text { CETESB }^{\star} \\
\mathbf{( m g / L )}\end{array}$ \\
\hline Antimônio & 0,37 & 0,016 & 0,005 \\
Bário & 5,95 & $<0,100$ & 0,700 \\
Chumbo & 28,70 & 0,018 & 0,010 \\
Ferro & 48,00 & $<0,300$ & 0,300 \\
Zinco & 11,60 & 0,184 & 5,000 \\
\hline
\end{tabular}

$\left(^{*}\right)$ Companhia Ambiental do Estado de São Paulo

Assim, embora sua eficácia em reduzir as concentrações de contaminantes organoclorados presentes em subsuperfície seja elevada, a procedência e a composição do permanganato de potássio, assim como de outros agentes, devem ser avaliadas cuidadosamente.

\section{4 ÁREA DE ESTUDO}

A área abordada encontra-se a cerca de $150 \mathrm{~km}$ a noroeste da Região Metropolitana do Estado de São Paulo e foi usada entre 1990 e 1998 como local de estocagem temporária de tambores preenchidos com resíduos utilizados no setor de produção de uma fábrica de peças automotivas e área de lavagem de veículos. Estas áreas foram identificadas como Área Potencialmente Contaminada (AP), respectivamente AP-2 e AP-3. Tais resíduos eram principalmente efluentes oriundos da área de lavagem e desengraxe das peças produzidas.

\subsubsection{Geologia E HidRoGEOLOGIA}

A área está inserida na borda leste da Bacia do Paraná, onde, regionalmente, podem ser identificadas as Formações Corumbataí, Irati, Tatuí e Grupo Itararé (IPT, 1981). A partir de descrições geológicas realizadas durante perfurações do solo para instalação de poços de monitoramento foram identificados três níveis de características distintas, sendo o primeiro classificado como aterro, devido à presença de areia de fundição e material de corte do próprio terreno (entulho de material de construção foi identificado localmente) e os demais, respectivamente, como manto de intemperismo e rocha pouco alterada. As características deste material indicam correlação com as litologias referentes ao membro inferior da Formação Tatuí, reconhecida por Barbosa e Gomes (1958, apud IPT, 1981) e Soares (1972b, apud IPT, 1981). A Figura 21 apresenta uma seção esquemática da estratigrafia encontrada na área. 
O nível superior do manto de intemperismo é composto por silte argiloso com presença de areia fina, estruturas de laminação, alta plasticidade e coloração branca, roxa, vermelha, cinza e amarela. A seguir, observa-se o siltito, menos intemperizado, alta compacidade e coloração roxa. Esta camada de siltito, identificada como aquitarde, foi considerada como uma barreira natural e, portanto, perfurações que pudessem ultrapassá-la não foram consideradas para evitar uma possível mobilização dos contaminantes presentes no aquífero freático para níveis mais profundos.

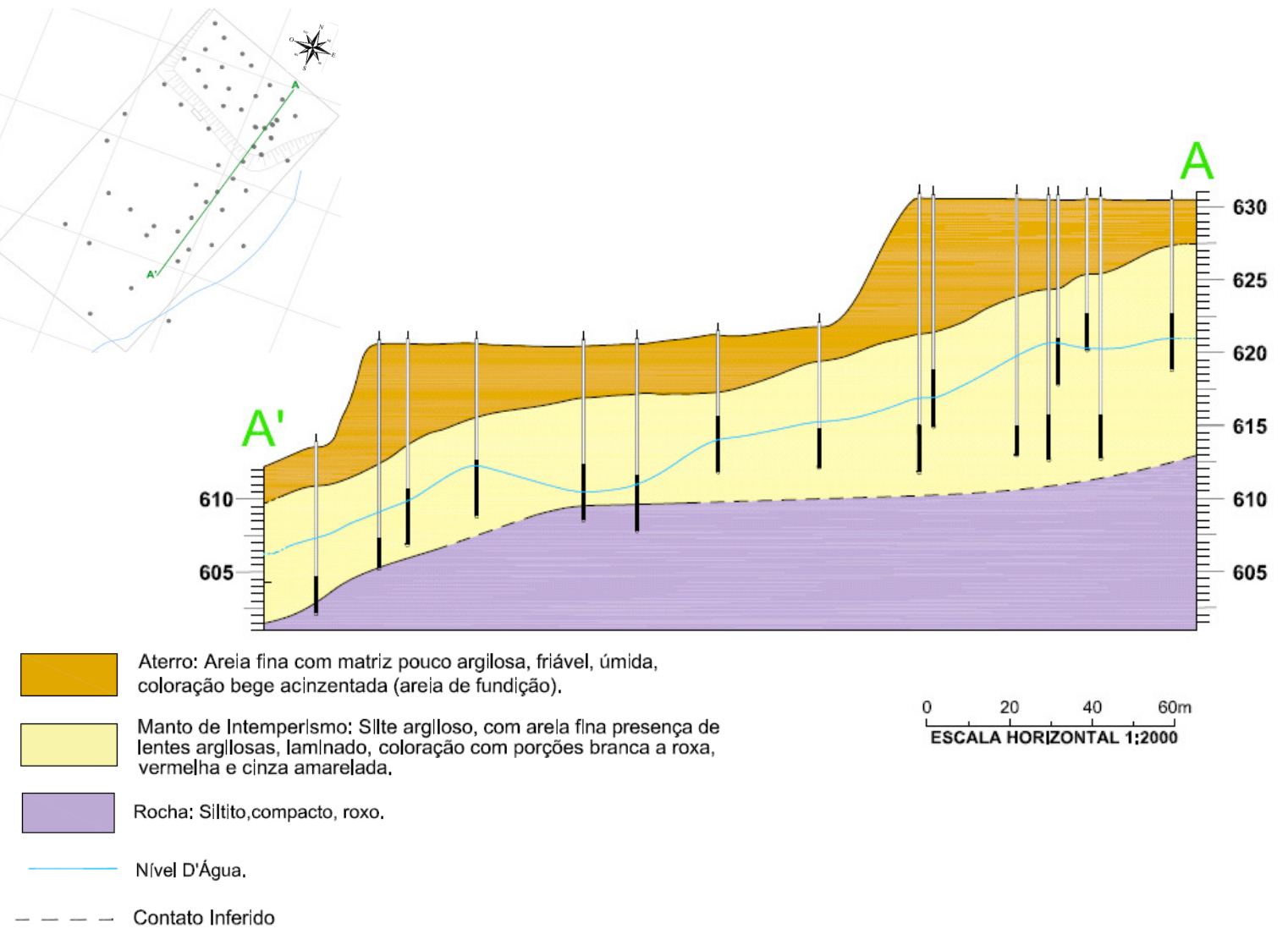

Figura 21 - Diagrama representativo da estratigrafia da área

De modo geral, a área de ocorrência da pluma de contaminação localiza-se em uma meia-encosta que corresponde à área de recarga do aquífero freático local (Figura 22). No limite sul, encontra-se a principal área de descarga da propriedade, um corpo de água intermitente de direção NE-SW. O mapa potenciométrico do local (Figura 22), obtido com dados de março de 2008, indica que a direção preferencial do fluxo da água subterrânea é $\mathrm{N}-\mathrm{S}$, com valores de cargas hidráulicas medidas variando entre 598,24 a 623,90 m. As cargas hidráulicas obtidas nos poços de monitoramento multiníveis instalados em profundidades distintas do aquífero freático indicam a existência de um potencial vertical descendente para o fluxo da água subterrânea no local. 


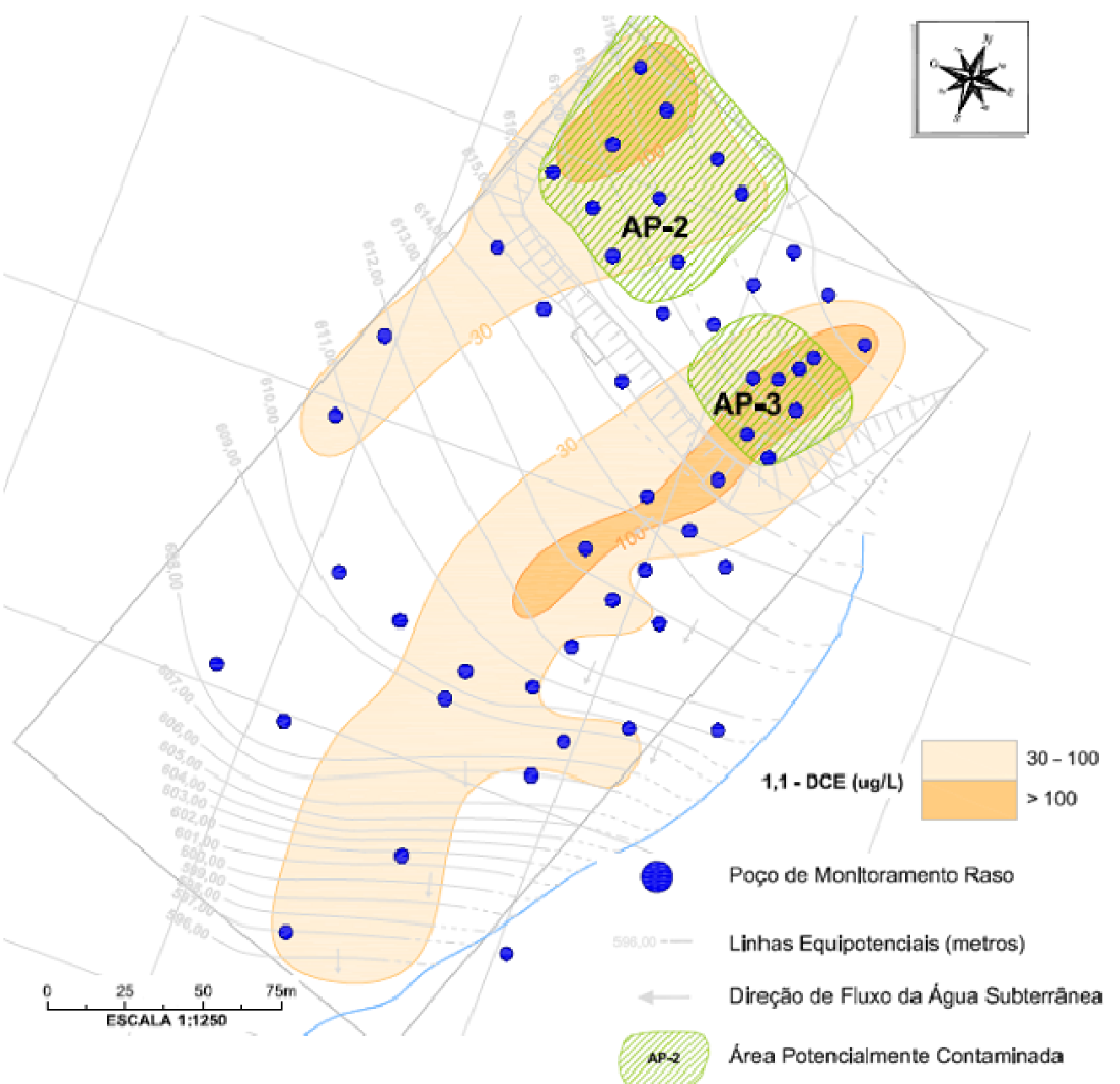

Figura 22 - Apresentação da direção preferencial do fluxo da água subterrânea do aquífero freático e a configuração da pluma de contaminação de 1,1-DCE antes da injeção do oxidante em toda a área (situação em março de 2008)

Testes hidráulicos realizados em seis poços de monitoramento existentes na área apresentaram valores de condutividade hidráulica variando entre $8,65 \times 10^{-5} \mathrm{~cm} / \mathrm{s}$ (poço localizado no limite noroeste) e $1,06 \times 10^{-4} \mathrm{~cm} / \mathrm{s}$ (poço localizado no limite sudeste). O valor médio de condutividade hidráulica obtido foi de $1,71 \times 10^{-4} \mathrm{~cm} / \mathrm{s}$. De acordo com os valores de carga hidráulica obtidos, foi calculada uma velocidade potencial média do fluxo da água subterrânea de $30 \mathrm{~m} / \mathrm{ano}$. Segundo USEPA (2008), locais que apresentem valores de condutividade hidráulica superiores a $1,00 \times 10^{-7} \mathrm{~cm} / \mathrm{s}$ podem ser considerados apropriados para a aplicação de tecnologias de remediação que envolvam injeção de fluidos no aquífero.

\subsubsection{Características da CONTAMinação}

Cerca de 20.000 tambores contendo resíduos provenientes do tratamento químico de materiais (galvanoplastia) e do desengraxe de peças produzidas na fábrica, foram dispostos no nível superior da área de estudo (AP-2), a noroeste do terreno (Figura 22). Uma segunda área potencialmente contaminada (AP-3) responsável pela contaminação de 
solventes clorados na água subterrânea do aquífero freático, encontrada a nordeste do terreno, envolvia atividades relacionadas à lavagem de veículos. Embora tenha sido identificada uma área onde cerca de $10.000 \mathrm{~m}^{3}$ de areia de fundição (areia contendo carvão vegetal em pó, bentonita, ferro e alumínio) e entulho de construção civil, utilizada como aterro, não há indicação de que este material tenha sido fonte de contaminação.

Apesar de produtos solventes originais, como PCE, TCE e 1,1,1-TCA terem sido estocados e manipulados na área, é o produto filho ou subproduto, 1,1-DCE, gerado pela degradação natural dos solventes utilizados, que aparece como o principal composto de interesse na água subterrânea. A Figura 22 traz a configuração da pluma de 1,1-DCE identificada na campanha de monitoramento de abril de 2008, anterior às atividades de remediação aplicadas em toda a área contaminada.

Os primeiros indícios de contaminação da água subterrânea foram observados em 1997, quando ocorreu a primeira investigação ambiental na área. A partir de então, foi necessária a instalação de cinqüenta e dois poços de monitoramento para identificar a área impactada. Por se tratarem de contaminantes de densidade superior à da água, foram instalados poços de monitoramento tanto no nível superior (entre 8 e $12 \mathrm{~m}$ de profundidade) quanto inferior do aquífero freático (entre 15 e $21 \mathrm{~m}$ de profundidade), onde é iniciado o topo da camada do aquitarde. Como mencionado, esta camada, de característica hidráulica de baixa permeabilidade, limitou as atividades de investigação com o objetivo de evitar uma potencial percolação dos contaminantes dissolvidos no aquífero freático para níveis mais profundos.

Em 2003, embora o impacto ambiental causado pela presença de VOC na água subterrânea ainda não estivesse delimitado, foi realizada uma avaliação de risco à saúde humana, que mostrou o composto 1,1-DCE como o principal contribuinte para o risco potencial de inalação de vapores provenientes da volatilização de contaminantes presentes na água subterrânea em ambientes fechados, por parte dos trabalhadores existentes na área. Baseada nesta circunstância, foi obtida a meta de remediação de $290 \mu \mathrm{g} / \mathrm{L}$ para este composto. A maior concentração detectada de 1,1-DCE na água subterrânea foi de $880 \mu \mathrm{g} / \mathrm{L}$, na campanha de monitoramento de maio de 2005.

Por conta dos resultados encontrados nas etapas de investigação e avaliação de risco, foi necessária a consideração de medidas de remediação para redução das concentrações dos contaminantes presentes na porção mais impactada do aquífero freático. Para a implantação da metodologia de remediação, foram considerados os critérios de eficácia, implementabilidade técnica, restrições de tempo, aceitação do órgão ambiental e custo. 
Assim, uma série de atividades envolvendo ensaios técnicos em campo e laboratório foram necessários para avaliar se a metodologia de remediação pela oxidação química in situ seria a mais adequada para tratamento dos contaminantes presentes nas fases dissolvida e adsorvida. $O$ item a seguir apresentará de forma detalhada a metodologia aplicada nas etapas de trabalho realizadas.

\subsection{MATERIAIS E MÉTODOS}

A condução de atividades que visem à reabilitação de uma área pela aplicação de determinada alternativa de remediação, principalmente as que envolvem técnicas químicas destrutivas de contaminantes, deve ser embasada por conhecimentos práticos de como o meio responderá. Assim, resultados de ensaios realizados em campo e em laboratório devem ser avaliados antes de qualquer tomada de decisão.

Uma descrição das atividades desenvolvidas na área de estudo é apresentada, desde a condução de ensaios em campo e laboratório, para avaliar as características específicas da área, até a aplicação da ISCO em toda a área contaminada como técnica de remediação.

\subsubsection{Ensaios em Campo E EM Laboratório}

Os ensaios de campo e laboratório foram conduzidos com o objetivo de trazer respostas quanto ao comportamento hidráulico do aquífero frente à injeção de fluido e às características da contaminação e do meio em que estão inseridas.

\section{Teste de injeção de água}

Um teste de injeção de água foi realizado com o objetivo de avaliar a efetividade hidráulica do aquífero freático em transportar o reagente de forma apropriada no seu interior. Para conduzir o teste, foram instalados dois poços de injeção a jusante da pluma existente a nordeste da área. Os poços foram construídos com a profundidade de $15 \mathrm{~m}$, onde foi localizado o topo da camada do aquitarde (siltito). Os procedimentos de instalação destes poços foram semelhantes aos descritos na Norma Brasileira NBR 1595-1 (ABNT, 2007) aplicada para poços de monitoramento, exceto pelo fato da seção filtrante ser totalmente penetrante no aquífero freático (início da seção filtrante onde o nível saturado do solo foi identificado, neste caso $7 \mathrm{~m}$ de profundidade). A Figura 23 apresenta um modelo do perfil construtivo dos poços de injeção instalados na área. O objetivo da instalação de poços de injeção com a seção filtrante totalmente penetrante no aquífero freático foi facilitar o contato do oxidante com o contaminante em todo nível saturado onde a contaminação foi identificada. 


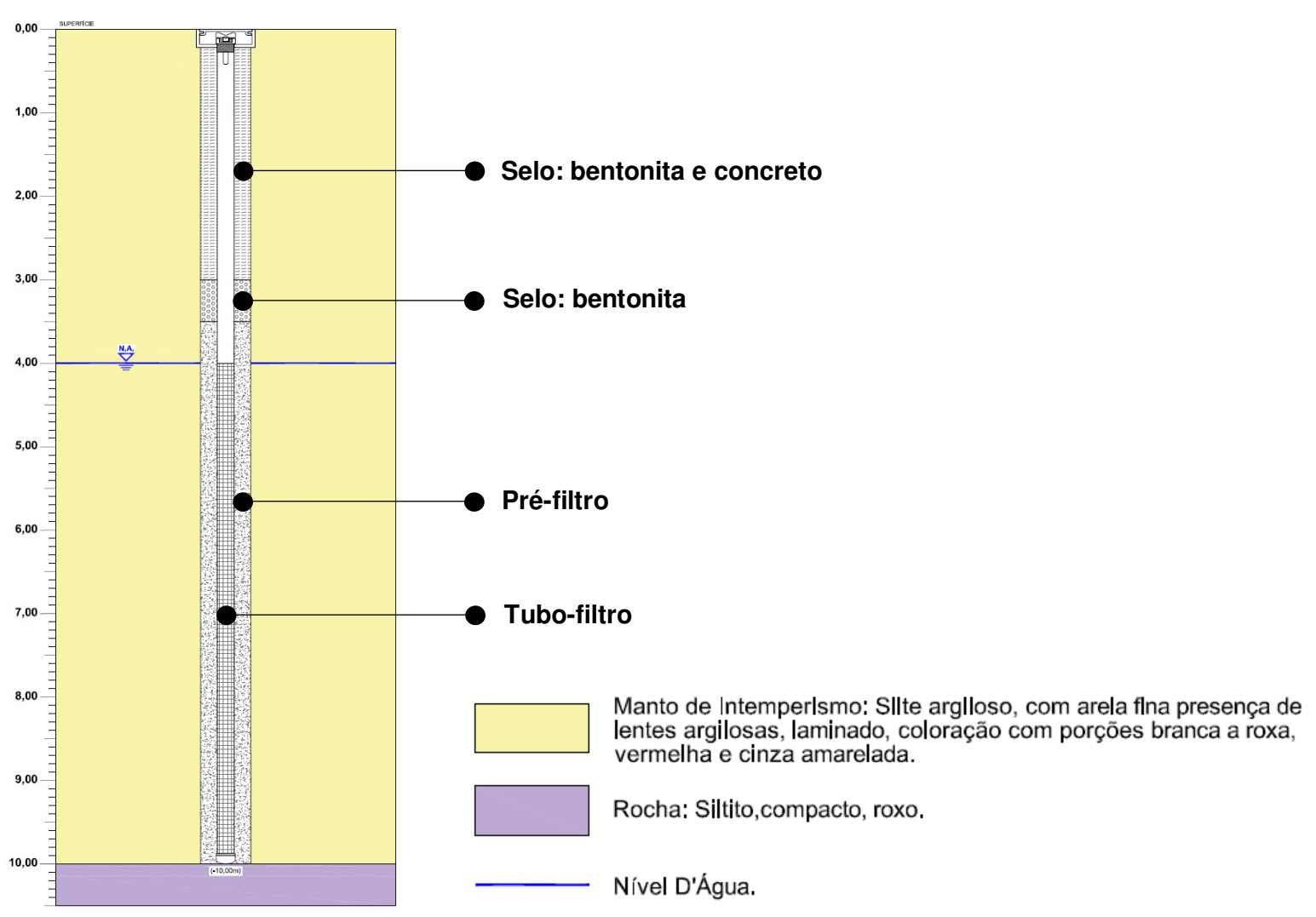

Figura 23 - Perfil construtivo esquemático de um poço de injeção

O teste de injeção de água consistiu na injeção de água captada do abastecimento público da região pelo período de 6 horas contínuas com carga constante, para isso foi utilizado um reservatório de água de $2.000 \mathrm{~L}$. O teste em cada um dos poços de injeção foi realizado em dias diferentes, após a verificação do retorno do nível d'água estático identificado antes do início dos testes para evitar interferências nos resultados. Em cada um dos testes de injeção, onze poços de monitoramento existentes até $57 \mathrm{~m}$ de distância foram monitorados para avaliar a variação do nível d'água durante as 6 horas de injeção. Os resultados deste teste permitiriam avaliar o potencial raio de influência inicial de injeção.

\section{Análises laboratoriais para avaliar características específicas do solo e eficiência do oxidante}

Amostras de solo saturado foram coletadas em três pontos distintos da área contaminada em profundidades variando entre 7 e $12 \mathrm{~m}$ para análises químicas de ferro total, carbono orgânico total e SOD. Para a análise de SOD, as amostras das diferentes profundidades de cada ponto foram homogeneizadas e tituladas com $\mathrm{KMNO}_{4}$.

Amostras de solo foram também coletadas e enviadas a um laboratório para análise de tratabilidade, que corresponde a uma avaliação da efetividade do permanganato de potássio em ser um composto favorável para a oxidação eficiente dos contaminantes presentes na amostra. 


\subsubsection{INJEÇÃo do OXIDANTE EM Escala de Teste Piloto}

Devido ao alto custo envolvido na aplicação de uma metodologia de remediação, é importante que seja primeiramente realizado um teste em uma área de dimensões limitadas que representem as características do meio e contaminação como um todo. As técnicas aplicadas no teste piloto devem ser semelhantes à que potencialmente será empregada, posteriormente em toda a área.

O local que apresentava as maiores concentrações de 1,1-DCE foi selecionado para a aplicação da ISCO como teste piloto (centro da pluma de contaminação a nordeste da área). Com base no raio de influência inicial identificado a partir dos resultados do teste de injeção de água, foram instalados sete poços de injeção de perfil construtivo semelhante ao apresentado na Figura 23, mas com profundidades variando entre 18 e $20 \mathrm{~m}$, onde foi identificado o topo da camada de aquitarde.

Para dimensionar a área impactada que seria primeiramente tratada neste teste piloto e avaliar os custos envolvidos, foi necessário verificar características específicas da área de estudo. Desta forma, com base nas informações levantadas em testes e análises anteriores, foram obtidos, conforme apresentado anteriormente: o volume de solo saturado impactado (equação 11); o coeficiente de distribuição do contaminante (equação 12); a concentração média adsorvida no solo (equação 13); a massa de contaminante adsorvida na matriz sólida do aquífero (equação 14); o volume efetivo de solo contaminado que entrará em contato com o oxidante por poço de injeção (equação 15); a massa de oxidante necessária para tratamento da área do teste piloto (equação 16); e a concentração do oxidante utilizado na solução (equação 17).

$$
\begin{aligned}
& \mathrm{V}=\mathrm{A} \cdot \mathrm{h} \\
& \mathrm{K}_{\mathrm{d}}=\mathrm{K}_{\mathrm{oc}} \cdot \mathrm{f}_{\mathrm{oc}} \\
& \mathrm{C}_{\mathrm{s}}=\mathrm{K}_{\mathrm{d}} \cdot \mathrm{C}_{\mathrm{a}} \\
& \mathrm{M}_{\mathrm{s}}=\mathrm{V} \cdot \rho \cdot \mathrm{C}_{\mathrm{s}} \cdot 10^{-3} \\
& \mathrm{~V}_{\mathrm{e}}=\pi \cdot \mathrm{R}^{2} \cdot \mathrm{h} \cdot \mathrm{n}_{\mathrm{e}} \\
& \mathrm{M}_{\mathrm{o}}=\mathrm{V} \cdot \rho \cdot \mathrm{SOD} \\
& \mathrm{V}_{\mathrm{as}}=\mathrm{M}_{\mathrm{o}} / \mathrm{C}_{\mathrm{o}}
\end{aligned}
$$

Onde,

$$
A=\text { Área impactada }\left(m^{2}\right)
$$


$\mathrm{V}=$ Volume de solo saturado contaminado $\left(\mathrm{m}^{3}\right)$

$\mathrm{h}=$ Espessura saturada contaminada do aquífero $(\mathrm{m})$

$\mathrm{K}_{\mathrm{d}}=$ Coeficiente de distribuição ou de partição $(\mathrm{mg} / \mathrm{g})$

$\mathrm{K}_{\mathrm{oc}}=$ Coeficiente de partição de carbono orgânico $(\mathrm{mg} / \mathrm{g})$

$\mathrm{f}_{\mathrm{oc}}=$ Fração de carbono orgânico contida no solo (\%)

$\mathrm{C}_{\mathrm{a}}=$ Concentração média dissolvida na água subterrânea ( $\left.\mathrm{mg} / \mathrm{L}\right)$

$\mathrm{C}_{\mathrm{s}}=$ Concentração média adsorvida no solo $(\mathrm{mg} / \mathrm{kg})$

$\rho=$ Densidade do solo $\left(\mathrm{g} / \mathrm{cm}^{3}\right)$

$M_{s}=$ Massa de contaminante no solo saturado $(\mathrm{kg})$

$R=$ Raio de influência por poço de injeção $(m)$

$\mathrm{V}_{\mathrm{e}}=$ Volume efetivo de solo contaminado que terá contato com o oxidante por poço de injeção $\left(\mathrm{m}^{3}\right)$

$\mathrm{n}_{\mathrm{e}}=$ Porosidade efetiva $(\%)$

$\mathrm{SOD}=$ Demanda de oxidante no solo $\left(\mathrm{g} \mathrm{KMnO}_{4} / \mathrm{kg}\right.$ solo)

$\mathrm{M}_{\mathrm{o}}=$ Massa de Oxidante $(\mathrm{kg})$

$\mathrm{C}_{0}=$ Concentração do oxidante (\%)

$\mathrm{V}_{\mathrm{as}}=$ Volume de água para solução $(\mathrm{L})$

Com o conhecimento da dosagem e volume de solução de permanganato de potássio ideais para a realização do teste piloto de maneira a atingir os resultados desejados, partiu-se para a instalação do sistema de injeção. Todo o sistema de injeção (tanques e bombas) foi instalado em uma bacia de contenção feita de concreto e com capacidade de $20 \mathrm{~m}^{3}$. Toda a solução foi preparada em um tanque de mistura de $1 \mathrm{~m}^{3} \mathrm{e}$ encaminhada para dois tanques de $10 \mathrm{~m}^{3}$ para posterior injeção.

A tubulação e equipamentos do sistema de injeção foram construídos de PVC e PEAD (polietileno de alta densidade), por apresentarem compatibilidade química com o permanganato de potássio, evitando deterioração das peças em contato com a solução injetada pela oxidação.

Os poços de injeção e de monitoramento nas proximidades foram constantemente monitorados para evitar excesso de pressão, o que poderia causar vazamentos da solução nas linhas e nos poços de injeção e afloramento do nível d'água causado pelo volume injetado.

Para se evitar o dano dos medidores dos parâmetros físico-químicos, durantes os monitoramentos, os mesmos não foram utilizados nos poços de monitoramento onde foi notada a presença do permanganato de potássio.

Para avaliar a eficiência da ação do permanganato frente ao contaminante presente no meio, amostras de água subterrânea foram coletadas e analisadas para VOCs. A avaliação geoquímica da área foi comprometida, já que não foi possível para o laboratório a 
realização de análises químicas para avaliação das concentrações de metais dissolvidos na água subterrânea na presença de permanganato de potássio. Tal decisão por parte do laboratório foi tomada de forma a evitar possíveis danos aos equipamentos. Pelo mesmo motivo, os parâmetros físico-químicos ( $\mathrm{pH}$, Eh, temperatura e condutividade elétrica) não puderam ser medidos em campo após a injeção da solução oxidante.

Como procedimento de amostragem, a água subterrânea coletada com presença de permanganato de potássio para análise de VOC foi neutralizada com tiosulfato de sódio para que as características da contaminação fossem representativas do momento da coleta, mas para isso não puderam ser preservadas com $\mathrm{HCl}$, apenas refrigeradas até a entrega no laboratório e análise.

\subsubsection{INJEÇÃo do OXIDANTE EM ESCALA DE REMEDIAÇÃo}

A implantação do sistema de remediação da ISCO em toda a área contaminada foi realizada de forma semelhante ao teste piloto, com: 1) instalação de poços de injeção; 2) injeção do agente oxidante; 3) monitoramento do comportamento do aquífero freático e 4) monitoramentos de desempenho do $\mathrm{KMnO}_{4}$ em diminuir as concentrações de 1,1-DCE.

Após avaliação das configurações das plumas de 1,1-DCE e as características físico-químicas da área, foram instalados trinta e um poços de injeção em adição aos nove existentes, com profundidades variando entre 18 e $20 \mathrm{~m}$. Os perfis construtivos destes poços são semelhantes ao apresentado na Figura 23, de forma que o oxidante injetado pudesse entrar em contato com o contaminante presente em toda a seção saturada do aquífero freático.

Todo o cálculo de dosagem do permanganato de potássio e volume de solução necessário para que houvesse o maior contato possível do oxidante com o contaminante foi conduzindo de acordo com as equações (11) a (17), apresentadas anteriormente.

Durante a etapa de injeção da solução do permanganato, o aquífero freático foi monitorado de forma a identificar a presença do oxidante e variação do nível de água dos poços de monitoramento. Estas atividades foram realizadas durante todo o período de injeção e forneceram informações importantes quanto ao real raio de influência do oxidante.

Os monitoramentos para avaliar a eficiência do processo de remediação ocorreram em um, três, seis, quinze e vinte e dois meses após a injeção do permanganato. Nestes períodos, foram coletadas amostras de água subterrânea para análises químicas de VOC e metais dissolvidos, para indicar, respectivamente, o abatimento da massa de contaminante e possível mobilização de compostos presentes naturalmente no meio. Assim como o ocorrido durante o teste piloto, nos poços de monitoramento onde a presença de permanganato de potássio foi observada, a coleta de amostras para análise não foi possível, assim como também não foram realizadas medições dos parâmetros físico-químicos 
visando a não danificação dos aparelhos.

\subsection{APRESENTAÇÃo E Discussão dos RESUltados}

\subsubsection{Ensaios em Campo e em Laboratório}

\section{Teste de injeção de água}

Durante o período de injeção, os níveis de água de onze poços de monitoramento e um dos poços de injeção utilizados no teste foram medidos a cada três horas para avaliar o comportamento do aquífero freático, quanto à percolação da água injetada. A variação média do nível d'água dos poços utilizados no teste ao longo do período de 6 horas de injeção é apresentada na Tabela 23.

Tabela 23 - Avaliação dos resultados do teste de injeção de água

\begin{tabular}{|c|c|c|c|c|c|c|c|}
\hline \multicolumn{4}{|c|}{ RW-01 } & \multicolumn{4}{|c|}{ RW-02 } \\
\hline Poço & $\begin{array}{c}\text { Distância } \\
\text { (m) }\end{array}$ & $\begin{array}{c}\text { Direção em relação } \\
\text { ao } \mathrm{RW}-01\end{array}$ & $\begin{array}{c}\text { Variação do nível de } \\
\text { água }(\mathrm{m})\end{array}$ & Poço & $\begin{array}{c}\text { Distância } \\
\text { (m) }\end{array}$ & $\begin{array}{c}\text { Direção em relação } \\
\text { ao } \mathrm{RW}-02\end{array}$ & $\begin{array}{c}\text { Variação do nível de } \\
\text { água }(\mathrm{m})\end{array}$ \\
\hline RW-02 & 6,60 & Jusante & 0,248 & RW-01 & 6,60 & Montante & 0,050 \\
\hline MW-01 & 6,60 & Montante & 0,092 & MW-01 & 6,60 & Montante & 0,049 \\
\hline MW-02 & 37,40 & Jusante & $-0,025$ & MW-02 & 32,45 & Jusante & $-0,007$ \\
\hline MW-03 & 49,50 & Jusante & 0,005 & MW-03 & 48,40 & Jusante & $-0,005$ \\
\hline MW-04 & 47,85 & Jusante & 0,005 & MW-04 & 49,50 & Jusante & 0,000 \\
\hline MW-08 & 26,95 & Montante & 0,015 & MW-08 & 33,00 & Montante & 0,030 \\
\hline MW-09 & 23,10 & Montante & 0,028 & MW-09 & 23,65 & Montante & 0,030 \\
\hline MW-10 & 19,25 & Jusante & 0,005 & MW-10 & 18,70 & Jusante & 0,020 \\
\hline MW-11 & 34,10 & Montante & 0,025 & MW-11 & 41,25 & Montante & 0,032 \\
\hline MW-12 & 53,90 & Jusante & 0,010 & MW-12 & 57,75 & Jusante & 0,000 \\
\hline MW-13 & 42,90 & Jusante & 0,010 & MW-13 & 44,00 & Jusante & 0,000 \\
\hline MW-14 & 42,35 & Jusante & 0,005 & MW-14 & 40,70 & Jusante & 0,005 \\
\hline
\end{tabular}

A variação do nível d'água observada em poços de monitoramento distantes até $18 \mathrm{~m}$ dos poços de injeção, no curto período de seis horas que durou o teste, foi devido à movimentação radial da água subterrânea causada pelo grande volume de água injetado (mais de $6.000 \mathrm{~L}$ de água em cada um dos poços de injeção), e não ao caminhamento real da água injetada até tal distância. Com base na observação da variação do nível d'água entre os poços de injeção e o poço de monitoramento MW-01, estimou-se que poderia ser assumido como raio de influência inicial de injeção, a distância de 6,60 m.

Além disso, considera-se que o oxidante acompanha o caminhamento natural do fluxo da água subterrânea após o término do período de injeção. Portanto, através dos fenômenos da advecção e dispersão, esperou-se que o oxidante alcançasse uma maior área e, enquanto permanecer presente no meio estaria reagindo com os contaminantes orgânicos até seu completo consumo. 
Análises laboratoriais para avaliar características específicas do solo e eficiência do oxidante

Os resultados das análises químicas realizadas para identificar a presença de compostos potencialmente oxidáveis, como ferro ferroso e carbono orgânico total, no solo saturado que entrará em contato com o permanganato de potássio são apresentados na Tabela 24. São apresentados também os resultados de SOD, que deram a indicação da dose necessária de aplicação de permanganato de potássio para que compostos orgânicos presentes no solo fossem oxidados. A amostra de solo do ponto SS-01 não pôde ser utilizada para a análise devido ao pouco volume de solo enviado ao laboratório.

Tabela 24 - Resultados analíticos utilizados para aplicação da ISCO

\begin{tabular}{ccccc}
\hline Ponto & $\begin{array}{c}\text { Profundidade } \\
\text { amostrada }(\mathbf{m})\end{array}$ & $\begin{array}{c}\text { Fe total } \\
(\mathbf{m g} / \mathbf{k g})\end{array}$ & $\begin{array}{c}\text { TOC } \\
(\%)\end{array}$ & $\begin{array}{c}\text { SOD } \\
\text { (gKMnO4/kgsolo) }\end{array}$ \\
\hline \multirow{3}{*}{ SS-01 } & 7,2 & 5.640 & 1,61 & - \\
& 10,0 & 1.857 & 0,88 & \\
& 12,0 & 1.724 & 0,61 & 0,29 \\
SS-02 & 7,0 & 907 & 1,44 & \\
& 9,0 & 5.730 & 1,61 & 0,86 \\
SS-03 & 11,0 & 50.240 & 2,27 & \\
& 6,5 & 20.696 & 2,28 & \\
& 7,5 & 15.504 & 1,94 & \\
\hline
\end{tabular}

Segundo os ensaios de tratabilidade conduzidos pelo laboratório, foi comprovada a eficiência do permanganato de potássio em oxidar os contaminantes organoclorados presentes nas fases dissolvida e adsorvida até concentrações aceitáveis pelos padrões de qualidade. Os resultados do ensaio de eficiência do permanganato de potássio em laboratório, juntamente com as características geoquímicas do aquífero e as concentrações muito inferiores ao limite de solubilidade do 1,1-DCE $(3.350 \mathrm{mg} / \mathrm{L})$, indicaram que a concentração de $1 \%$ do oxidante seria suficiente para a diminuição das concentrações dos contaminantes organoclorados presentes no meio.

Com base em informações específicas da área, foi possível dimensionar o sistema de remediação a ser aplicado prioritariamente como teste piloto e posteriormente em toda a área impactada pelo contaminante 1,1-DCE.

\subsubsection{INJEÇÃo do OXIDANTE EM Escala de Teste PILOTO}

Os resultados dos ensaios realizados em campo e em laboratório foram importantes para a seleção da ISCO como metodologia de remediação aplicável para a área. O teste de injeção de água mostrou que as condições hidráulicas do aquífero poderiam suportar a entrada de fluidos e os resultados analíticos apontaram para a 
viabilidade da utilização da oxidação química como alternativa de remediação. Portanto, o teste piloto foi conduzido na área determinada, de acordo com os dados apresentados na Tabela 25.

Tabela 25 - Informações necessárias para o cálculo do dimensionamento do sistema de remediação considerando o centro de massa de uma das plumas de 1,1-DCE a ser tratada no teste piloto e para a remediação de toda a área

\begin{tabular}{|c|c|c|c|}
\hline Dados & $\begin{array}{l}\text { Valores utilizados } \\
\text { no teste piloto }\end{array}$ & $\begin{array}{l}\text { Valores utilizados } \\
\text { na remediação }\end{array}$ & Unidade \\
\hline $\mathrm{A}=$ Área impactada considerada no teste piloto & 818 & 8.140 & $\overline{m^{2}}$ \\
\hline$V=$ Volume de solo saturado contaminado & 5.726 & 47.260 & $\mathrm{~m}^{3}$ \\
\hline $\mathrm{h}=$ Espessura saturada contaminada do aqüífero & 7 & 7 & $\mathrm{~m}$ \\
\hline $\mathrm{K}_{\mathrm{d}}=$ Coeficiente de distribuição ou de partição & 1,03 & 1,03 & $\mathrm{mg} / \mathrm{g}$ \\
\hline $\mathrm{K}_{\mathrm{oc}}=$ Coeficiente de partição de carbono orgânico & 65 & 65 & $\mathrm{mg} / \mathrm{g}$ \\
\hline $\mathrm{f}_{\mathrm{oc}}=$ Fração de carbono orgânico contida no solo & 1,58 & 1,58 & $\%$ \\
\hline $\mathrm{C}_{\mathrm{a}}=$ Concentração média dissolvida na água subterrânea & 0,20 & 0,20 & $\mathrm{mg} / \mathrm{L}$ \\
\hline $\mathrm{C}_{\mathrm{s}}=$ Concentração média adsorvida no solo & 0,21 & 0,21 & $\mathrm{mg} / \mathrm{kg}$ \\
\hline$\rho=$ Densidade do solo & 1,60 & 1,60 & $\mathrm{~g} / \mathrm{cm}^{3}$ \\
\hline$M_{s}=$ Massa de contaminante no solo saturado & 1,88 & 15,53 & $\mathrm{~kg}$ \\
\hline $\mathrm{R}$ = Raio de influência por poço de injeção & 6 & 6 & $\mathrm{~m}$ \\
\hline $\begin{array}{c}\mathrm{V}_{\mathrm{e}}=\text { Volume efetivo de solo contaminado que terá contato com o } \\
\text { oxidante por poço de injeção }\end{array}$ & 79,13 & 79,13 & $\mathrm{~m}^{3}$ \\
\hline $\mathrm{n}_{\mathrm{e}}=$ Porosidade efetiva & 10 & 10 & $\%$ \\
\hline SOD = Demanda de oxidante no solo & 0,30 & 0,30 & $\mathrm{~g} \mathrm{KMnO}_{4} / \mathrm{kg}$ solo \\
\hline $\mathrm{M}_{\mathrm{o}}=$ Massa de Oxidante & 2.748 & 22.685 & $\mathrm{~kg}$ \\
\hline $\mathrm{C}_{\mathrm{o}}=$ Concentração do oxidante & 0,44 & 0,50 & $\%$ \\
\hline $\mathrm{V}_{\mathrm{as}}=$ Volume de água para solução & 624.655 & 4.536 .960 & $\mathrm{~L}$ \\
\hline
\end{tabular}

A massa de oxidante utilizada no teste piloto foi de $2.800 \mathrm{~kg}$, o que ocasionou em uma pequena alteração nos valores finais de injeção quando comparados aos apresentados na Tabela 25. Para a obtenção de uma solução de $0,44 \%$ de concentração de permanganato de potássio, foi necessária a adição de $644 \mathrm{~m}^{3}$ de água distribuídos em sete poços de injeção. O volume total de injeção por poço variou entre 89 e $96 \mathrm{~m}^{3}$ de solução.

Durante as atividades de injeção, que se prolongou por duas semanas, a concentração de $\mathrm{KMnO}_{4}$ foi acompanhada nos quatorze poços de monitoramento existentes na área foco do teste piloto. Como resultado, a Figura 24 mostra a evolução da presença de $\mathrm{KMnO}_{4}$ observada nos poços de monitoramentos durante o período de injeção e nos monitoramentos de desempenho subsequentes. 


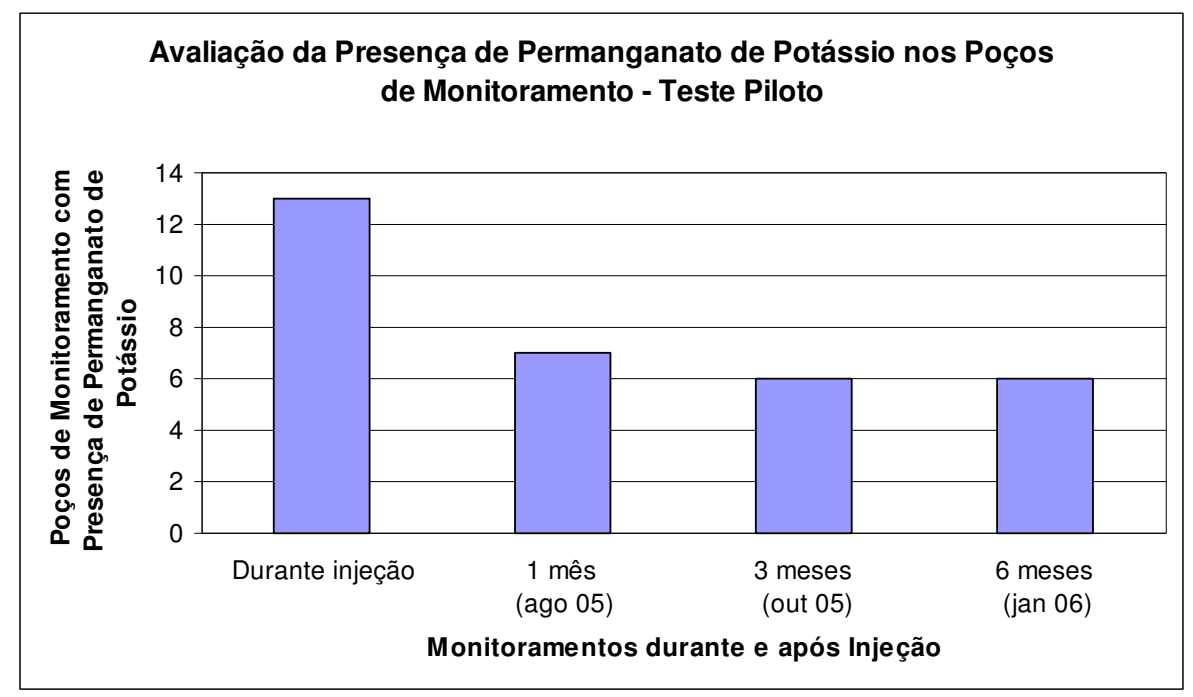

Figura 24 - Presença de $\mathrm{KMnO}_{4}$ nos poços de monitoramento durante e após o período de injeção do teste piloto

Observando a presença de permanganato de potássio nos poços de monitoramento na área do teste piloto foi possível avaliar o raio de influência que o oxidante pôde atingir, tanto durante o período de injeção, quanto nos monitoramentos de desempenho em um, três e seis meses após a injeção. Após dois dias de injeção, identificou-se permanganato de potássio em poços de monitoramentos distantes $7,5 \mathrm{~m}$ do poço de injeção mais próximo e após um mês, sua abrangência foi observada em poços instalados até $12 \mathrm{~m}$ de distância do ponto injetado.

Para avaliar os resultados da diminuição das concentrações de contaminantes organoclorados neste teste piloto, são apresentadas na Figura 25, as delimitações das plumas de 1,1-DCE em dois períodos de tempo, respectivamente, antes e seis meses após a injeção. Nesta figura são apresentados também a localização dos poços de injeção e os respectivos raios de influência, previstos inicialmente, de $6 \mathrm{~m}$. 


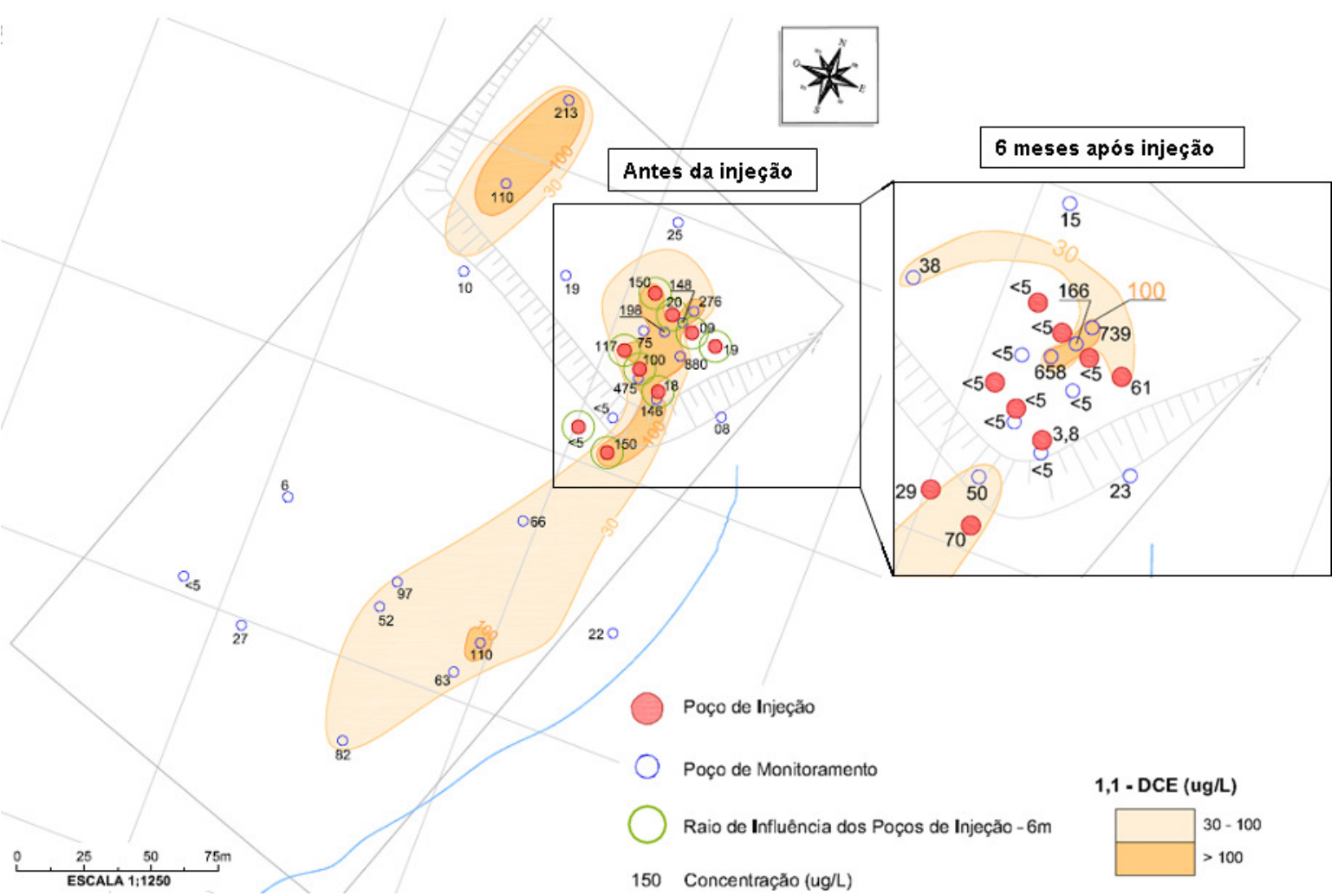

Figura 25 - Apresentação da área tratada no teste piloto e raios de influência inicialmente previstos de $6 \mathrm{~m}$ (situação em maio de 2005)

A Figura 25 indica que embora vários poços de monitoramento tenham apresentado diminuição nos valores de 1,1-DCE, outros tiveram aumento em suas concentrações. Com a injeção do permanganato, a matéria orgânica envolta dos grãos pode ser consumida pelo oxidante e liberar para a água subterrânea, possíveis contaminantes, anteriormente adsorvidos. Devido à persistência do $\mathrm{KMnO} 4$ na água subterrânea, conforme apresentada na Figura 24, as concentrações dos contaminantes tenderiam a diminuir ao longo do tempo, isto porque, como mencionado, enquanto o oxidante estiver presente na água subterrânea, estará reagindo.

\subsubsection{INJEÇÃo do OXIDANTE EM ESCALA DE REMEDIAÇÃo}

Os resultados do teste piloto foram considerados satisfatórios e, juntamente com os resultados dos demais testes realizados na área, houve embasamento prático para a aplicação da ISCO em toda a área impactada, visando a redução das concentrações de 1,1-DCE a níveis aceitáveis. Assim como realizado no teste piloto, os cálculos considerando dados específicos para a área e apresentados na Tabela 25 foram utilizados no dimensionamento do sistema de remediação. Assim, a massa de oxidante ideal para a remediação da área impactada de forma a alcançar concentrações de 1,1-DCE inferiores à meta de remediação foi de 23 toneladas. Com concentração da solução estimada em $0,5 \%$, 
foi necessário o volume de $46.000 \mathrm{~m}^{3}$ de água.

Em todos os poços de injeção foram instalados hidrômetros para que se pudesse verificar o volume de solução injetada. Ao final da injeção, observou-se que os poços de injeção receberam entre 4 e $175 \mathrm{~m}^{3}$ de solução. O valor médio injetado foi de $118 \mathrm{~m}^{3}$.

A instalação dos poços de injeção foi focada nos locais onde, historicamente, foram observadas as maiores concentrações de 1,1-DCE. Portanto, dezessete dos cinqüenta e oito poços de monitoramento instalados na área, poderiam não estar ao alcance do oxidante injetado. A Figura 26 apresenta o delineamento da pluma de contaminante identificado anteriormente às atividades de remediação, bem como o raio de influência inicial de injeção, previsto, de $6 \mathrm{~m}$.

A locação dos poços de injeção nos centros de ambas as plumas visou o abatimento de massa do contaminante, onde as concentrações encontravam-se superiores à meta de remediação e a dos poços a jusante desta área, na pluma de maior extensão, foi de evitar o caminhamento da área mais impactada para além dos limites investigados.

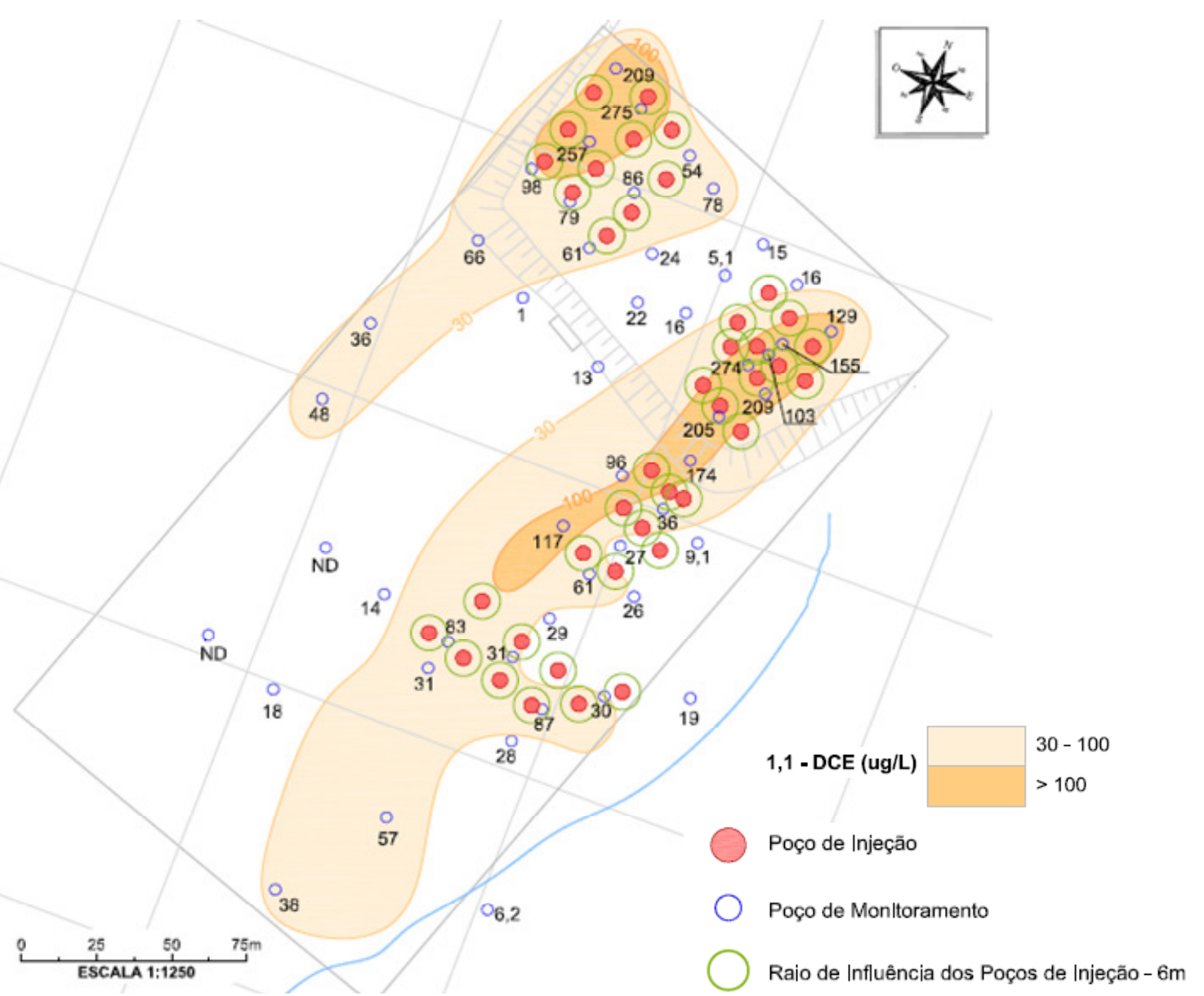

Figura 26 - Localização dos poços de injeção previstos para a remediação da área até concentrações inferiores à meta de remediação 
Uma das vantagens do uso do permanganato de potássio como alternativa de remediação de uma área contaminada por compostos organoclorados é o fato de oxidar os contaminantes por mais tempo, quando comparado a outros oxidantes como, por exemplo, o peróxido de hidrogênio. Sua persistência foi observada na área durante as atividades de monitoramento de desempenho e o resultado é apresentado na Figura 27.

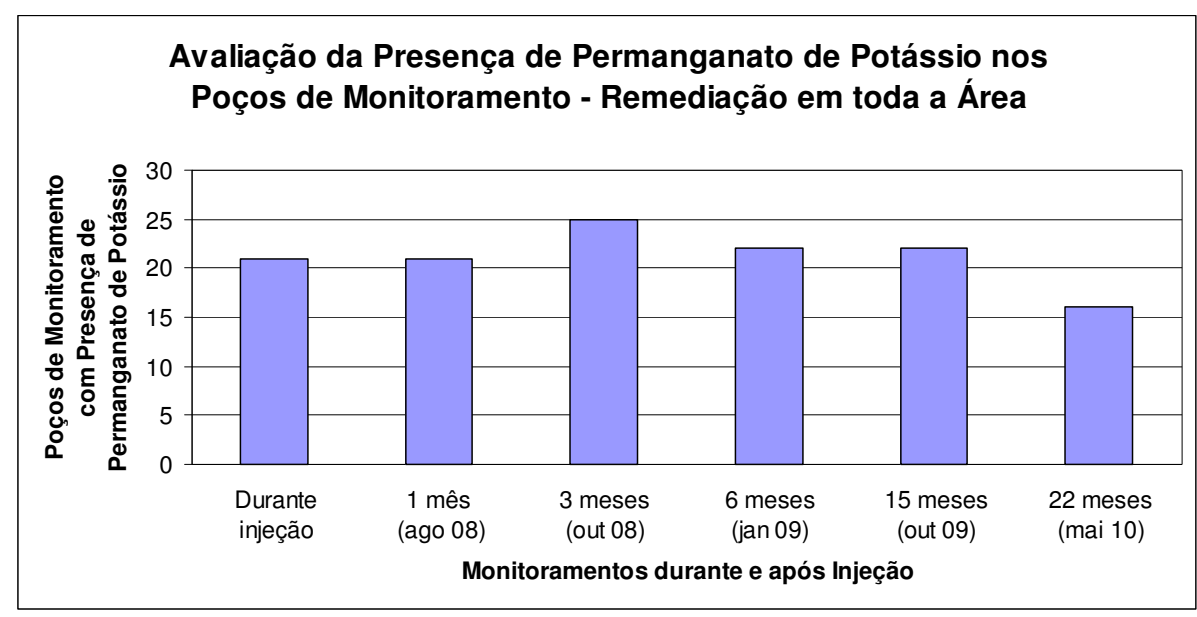

Figura 27 - Presença de $\mathrm{KMnO}_{4}$ nos poços de monitoramento durante e após o período de injeção em toda a área

Embora o raio de influência inicial de injeção esperado fosse de $6 \mathrm{~m}$, o permanganato de potássio foi observado em poços de monitoramento distantes até $18 \mathrm{~m}$ de pelo menos um poço de injeção e isto resultou em uma maior eficiência, como pode ser observado na Figura 27, onde nota-se que vinte e dois meses após a injeção, a maior concentração detectada foi de $309 \mu \mathrm{g} / \mathrm{L}$. Salienta-se que tal concentração embora se

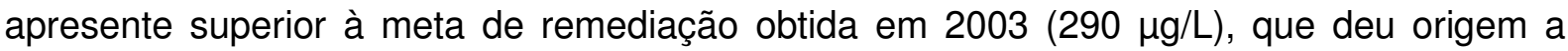
necessidade da aplicação de medidas corretivas de remediação, é muito inferior à obtida posteriormente, na atualização da avaliação de risco realizada em 2009. Nesse período, as características toxicológicas do 1,1-DCE foram revistas pela USEPA e tal composto passou a ser considerado como não carcinogênico. Fato que gerou um segundo cálculo de meta de remediação, onde o resultado obtido foi de $12.500 \mu \mathrm{g} / \mathrm{L}$.

Os poços de monitoramento instalados na base do aquífero freático apresentaram diminuição nas concentrações de 1,1-DCE até níveis inferiores ao limite de $30 \mu \mathrm{g} / \mathrm{L}$ estabelecido pelo órgão ambiental ou passaram a ser não quantificados nas análises químicas. 


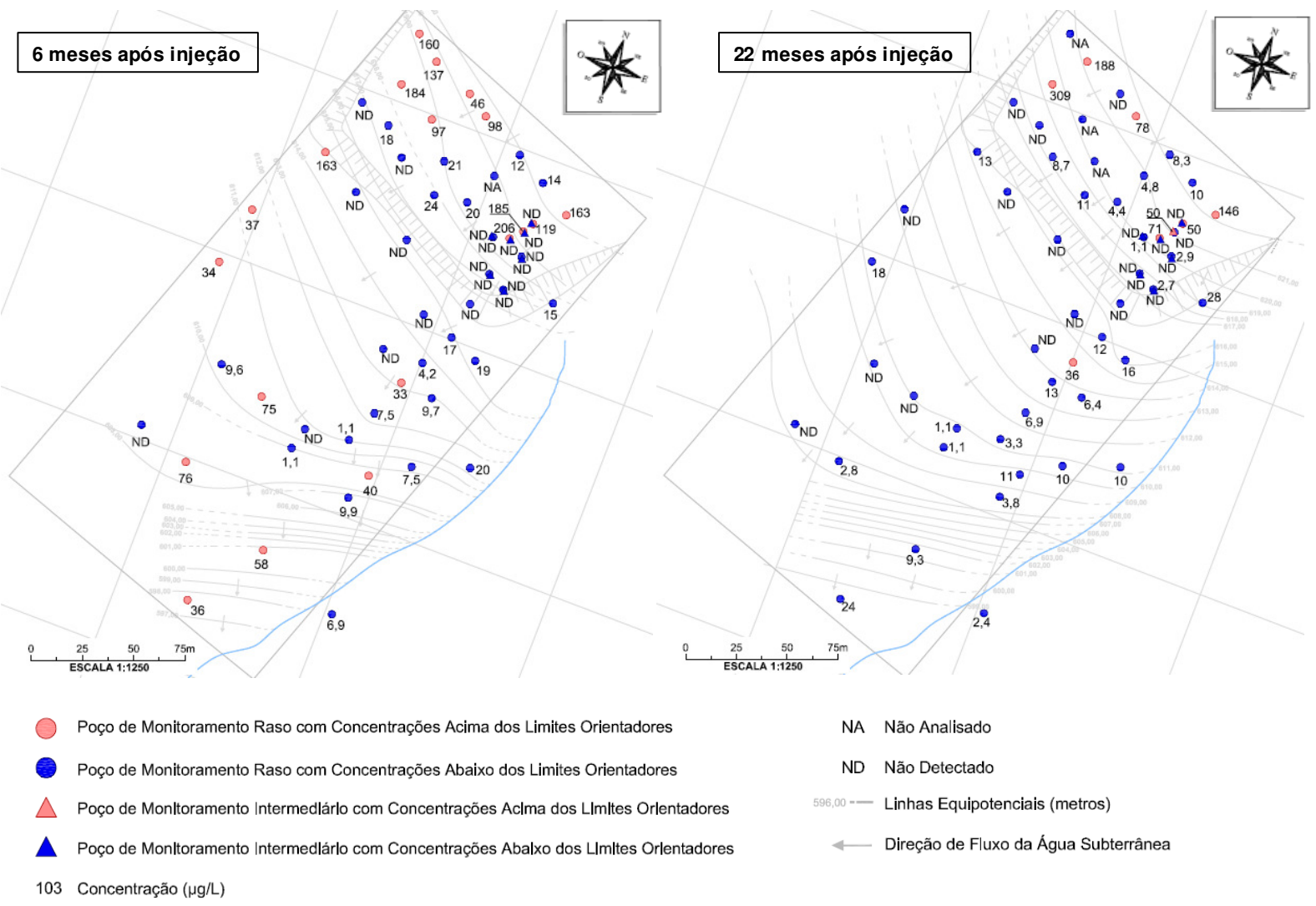

Figura 28 - Comparação entre os resultados de monitoramento de desempenho da ação do $\mathrm{KMnO}_{4}$ em seis e vinte e dois meses após as atividades de injeção em toda a área

Embora, de modo geral tenham sido observados bons resultados na aplicação da técnica química destrutiva de contaminantes na área onde a ISCO foi aplicada, foi também observada uma grande variação nas concentrações de alguns poços de monitoramento, como apresentado na Figura 29. 


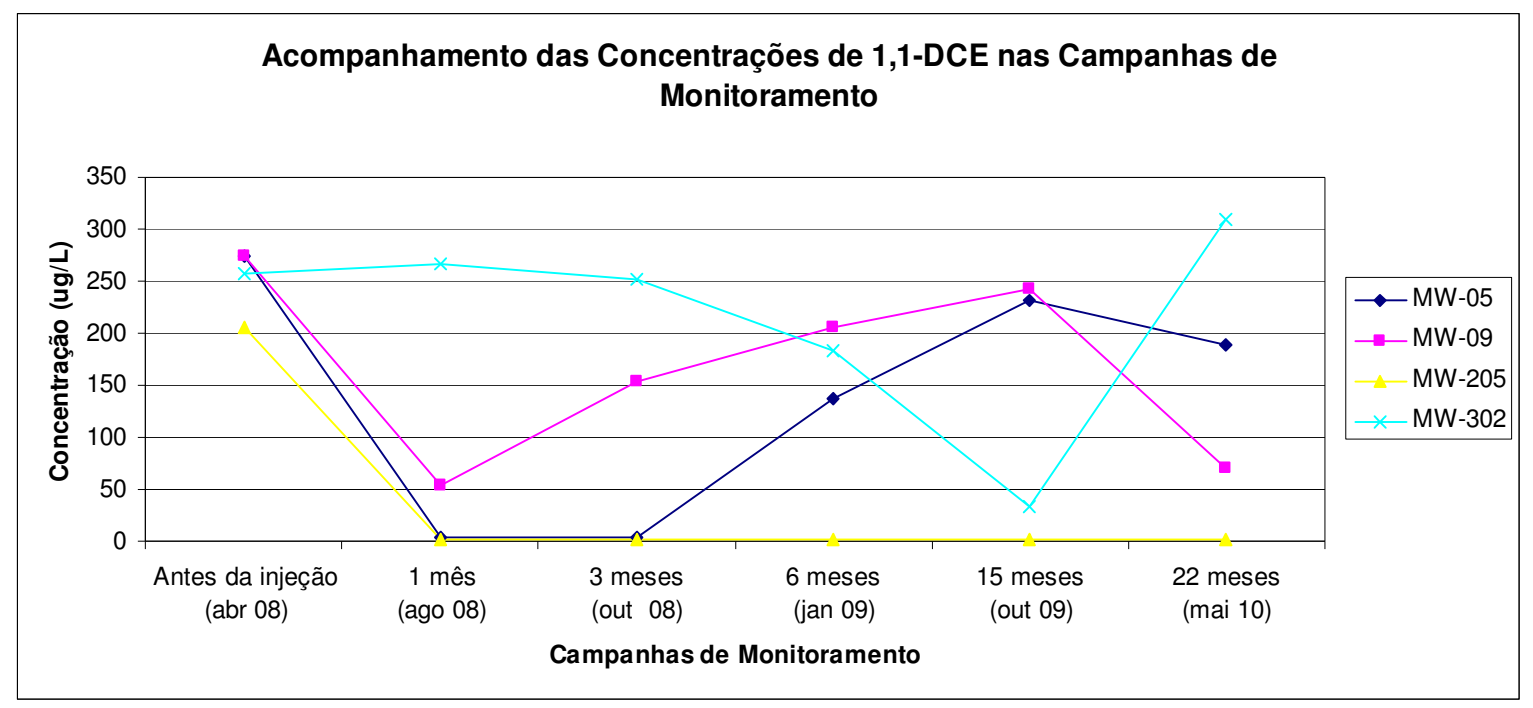

Figura 29 - Comportamento da concentração de 1,1-DCE ao longo das campanhas de monitoramento de desempenho do $\mathrm{KMnO}_{4}$ em alguns poços de monitoramento selecionados

Embora a avaliação geoquímica da área tenha sido comprometida pela impossibilidade de análise de metais na água subterrânea dos poços que apresentavam concentrações de permanganato de potássio, observou-se, de maneira geral, aumento nas concentrações de metais dissolvidos quando os resultados das análises dos últimos monitoramentos são comparados com os anteriores às atividades de injeção. Para elucidar tal comportamento, são apresentadas nas Tabelas 26 e 27, respectivamente, às concentrações médias e máximas detectadas ao longo das campanhas de monitoramento.

Tabela 26 - Concentrações médias de metais dissolvidos identificados na água subterrânea

\begin{tabular}{|c|c|c|c|c|c|c|c|}
\hline Elemento & $\begin{array}{l}\text { abr } 08 \\
\text { (mg/L) }\end{array}$ & $\begin{array}{l}\text { ago } 08 \\
(\mathrm{mg} / \mathrm{L})\end{array}$ & $\begin{array}{l}\text { out } 08 \\
\text { (mg/L) }\end{array}$ & $\begin{array}{l}\text { jan } 09 \\
\text { (mg/L) }\end{array}$ & $\begin{array}{l}\text { out } 09 \\
\text { (mg/L) }\end{array}$ & $\begin{array}{l}\text { mai } 10 \\
(\mathrm{mg} / \mathrm{L})\end{array}$ & $\begin{array}{c}\text { Referência } \\
\text { CETESB } \\
\text { (mg/L) }\end{array}$ \\
\hline Alumínio & 0,1130 & 0,1501 & 0,1036 & 0,0992 & 0,4342 & 1,2311 & 0,2 \\
\hline Bário & 0,2526 & 0,2288 & 0,3425 & 0,3059 & 0,6846 & 2,0197 & 0,7 \\
\hline Boro & 0,4050 & 0,0651 & 0,0723 & 0,1293 & 0,0940 & 0,9804 & 0,5 \\
\hline Cromo & 0,0089 & 0,0022 & 0,0324 & 0,0171 & 0,0302 & 0,0903 & 0,05 \\
\hline Ferro & 0,0774 & 0,0513 & 0,0308 & 0,0495 & 0,1144 & 0,2867 & 0,3 \\
\hline Manganês & 0,1811 & 0,0806 & 0,4082 & 0,4040 & 5,8960 & 5,3141 & 0,4 \\
\hline Vanádio & 0,2788 & 0,0046 & $<0,0005$ & $<0,0005$ & 0,0278 & 0,0007 & - \\
\hline Zinco & 0,0120 & 0,0143 & 0,0605 & 0,0306 & 0,0716 & 0,5271 & 5 \\
\hline
\end{tabular}


Tabela 27 - Concentrações máximas de metais dissolvidos identificados na água subterrânea

\begin{tabular}{|c|c|c|c|c|c|c|c|}
\hline Elemento & $\begin{array}{l}\text { abr } 08 \\
\text { (mg/L) }\end{array}$ & $\begin{array}{l}\text { ago } 08 \\
\text { (mg/L) }\end{array}$ & $\begin{array}{l}\text { out } 08 \\
\text { (mg/L) }\end{array}$ & $\begin{array}{l}\text { jan } 09 \\
\text { (mg/L) }\end{array}$ & $\begin{array}{l}\text { out } 09 \\
\text { (mg/L) }\end{array}$ & $\begin{array}{l}\text { mai } 10 \\
(\mathrm{mg} / \mathrm{L})\end{array}$ & $\begin{array}{c}\text { Referência } \\
\text { CETESB } \\
\text { (mg/L) }\end{array}$ \\
\hline Alumínio & 1,5920 & 1,0400 & 0,6436 & 1,1070 & 11,3670 & 4,7470 & 0,2 \\
\hline Bário & 5,5490 & 1,4380 & 2,5490 & 4,0020 & 17,8122 & 10,2600 & 0,7 \\
\hline Boro & 0,4171 & 0,5096 & 0,3868 & 1,4160 & 0,5271 & 1,9029 & 0,5 \\
\hline Cromo & 0,0190 & 0,0042 & 0,1135 & 0,0296 & 0,0976 & 0,1446 & 0,05 \\
\hline Ferro & 0,6201 & 0,2355 & 0,1275 & 0,3038 & 0,9920 & 0,8401 & 0,3 \\
\hline Manganês & 1,0850 & 0,7880 & 4,6070 & 2,9990 & 175,2744 & 39,0594 & 0,4 \\
\hline Vanádio & 0,5067 & 0,0087 & $<0,0005$ & $<0,0005$ & 0,0880 & 0,0013 & - \\
\hline Zinco & 0,0265 & 0,1212 & 1,0050 & 0,0774 & 0,1561 & 1,0008 & 5 \\
\hline
\end{tabular}

Nota-se que as concentrações de metais aumentaram de forma considerável até a amostragem de quinze meses após a injeção (outubro de 2009). Na última campanha realizada vinte e dois meses após as atividades de injeção (maio de 2010), observou-se, de modo geral, redução das concentrações. Seguindo tal comportamento, espera-se que as concentrações de metais diminuam até os níveis naturalmente encotrados na área, quando houver o consumo total do permanganato de potássio e as características físico-químicas do aquífero se normalizarem.

A redução das concentrações de manganês, observada em maio de 2010, após o pico identificado em outubro de 2009, indica que a precipitação desse composto como dióxido de manganês $\left(\mathrm{MnO}_{2}\right)$, passou a ocorrer de maneira mais consistente a partir de maio de 2010.

\subsection{CONCLUSÕES}

Com base no acompanhamento dos resultados analíticos após a aplicação da ISCO em toda a área impactada, entende-se que o oxidante entrou em contato direto com o contaminante na área foco da remediação, principalmente devido ao fluxo advectivo da água subterrânea, visto que o oxidante foi identificado em poços de monitoramentos existentes até $18 \mathrm{~m}$ de distância. Isto pode ser confirmado pela diminuição das concentrações do principal contaminante até a primeira meta de remediação calculada, com exceção de um único ponto. Apesar disso, a concentração detectada neste ponto apresenta-se muito inferior a segunda meta de remediação calculada devido às alterações nas características físico-químicas do composto 1,1-DCE concebidas pela USEPA.

A remediação também foi efetiva no nível inferior do aquífero, já que o oxidante injetado pelos poços de injeção de seção filtrante totalmente penetrante atingiu a água subterrânea dos poços de monitoramento instalados no topo da camada de aquitarde e 
resultou em redução nas concentrações de 1,1-DCE.

Resultados dos testes realizados em campo e laboratório mostraram a possibilidade de uma baixa dosagem do oxidante ser suficiente para a diminuição da contaminação existente. Isto foi confirmado pelos valores analíticos de 1,1-DCE observados ao longo das campanhas de monitoramento realizadas para avaliar a real eficiência do permanganato de potássio.

Quanto à avaliação dos efeitos geoquímicos devido à presença do permanganato de potássio na água subterrânea, não foi possível realizar com precisão devido à impossibilidade de análise química de metais dissolvidos, por parte do laboratório e de medição de parâmetros físico-químicos em campo. Apesar disso, onde foi possível a realização desta análise, notou-se aumento nas concentrações de metais como, alumínio, bário e ferro. O brusco aumento da concentração de manganês na amostragem de outubro de 2009 (quinze meses após as atividades de injeção) seguido por sua diminuição em maio de 2010 (vinte e dois meses após as atividades) indicou o período de consumo do permanganato de potássio mais intenso, onde potencialmente, passou a ocorrer a precipitação deste composto como dióxido de manganês.

Espera-se que as concentrações de metais observadas acima dos limites estabelecidos pelo órgão ambiental (CETESB) comecem a ser reduzidas até o retorno à níveis naturalmente presentes no aquífero local, conforme o consumo do permanganato de potássio pelos compostos organoclorados ainda presentes no meio.

\subsection{REFERÊNCIAS BIBLIOGRÁFICAS}

ASSOCIAÇÃO BRASILEIRA DE NORMAS TÉCNICAS. Poços de monitoramento de água subterrâneas em aqüíferos granulares - NBR 15495-1:2007. ABNT, 2007, 33p.

BARBOSA, O; GOMES, F. A. (1958), Pesquisa de petróleo na bacia do Rio Corumbataí, Estado de São Paulo. Bol. Div. Geol. Min., Rio de Janeiro, DNPM, (171): 1-40.

CRIMI, M. L.; SIEGRIST, R. L. (2003), Geochemical Effects on Metals Following Permanganate Oxidation of DNAPLs. Ground Water, v. 41, No. 4, 458-469.

DEPARTMENT OF ENERGY - DOE (1999), In situ chemical oxidation using potassium permanganate, Piketon, Ohio, United States (DOE/EM-0496).

ENVIRONMENTAL RESOURCES MANAGEMENT - ERM (2009), Oxidação química in situ - Implementação e operação do sistema full scale e monitoramento (0076129).

HØNNING, J. (2007), Use of in situ chemical oxidation with permanganate in PCEcontaminated clayey till with sand lenses. Ph.D. Thesis, Institute of Environment \& Resources Technical University of Denmark.

HU, G. J.; CHOU, R. (2002), Pilot test using potassium permanganate solution for VOCsimpacted groundwater cleanup. Third International Conference on Remediation of Chlorinated and Recalcitrant Compounds, Monterey, CA.

INSTITUTO DE PESQUISAS TECNOLÓGICAS - IPT (1981), Mapa geológico do Estado de São Paulo. São Paulo, IPT. v.1. Escala 1: 500.000. 
MARVIN, B. K.; CHAMBERS, J.; LEAVITT, A. (2002), Chemical and Engineering challenges to in situ permanganate remediation. Third International Conference on Remediation of Chlorinated and Recalcitrant Compounds, Monterey, CA.

PANKOV, J. F.; CHERRY, J. A. (1996), Dense chlorinated solvents and other DNAPLs in groundwater, Ontario, Canada.

SOARES, P. C. (1972b), O limite glacial-pós-glacial do Grupo Tubarão no Estado de São Paulo. An. Acad. Brás. Ci., Rio de Janeiro, 44(supl.): 333-341.

SUTHERSAN, S. S.; PAYNE, F. C. (2005), In Situ Remediation Engineering, Washington, DC, United States of America.

UNITED STATES ENVIRONMENTAL PROTECTION AGENCY - EPA (2004), Monitored Natural Attenuation, United States (EPA/510/R-04-002).

UNITED STATES ENVIRONMENTAL PROTECTION AGENCY - USEPA (2008), Chemical Oxidation Guidance, Illinois, United States.

\section{CONCLUSÕES}

\subsection{INJEÇÃo do REDUTOR EM ESCALA DE TESTE PILOTO}

Considerando as interpretações apontadas sobre os resultados obtidos, assim como tendo em mente a proposta inicial do trabalho, foi possível reunir argumentos para a conclusão apresentada a seguir.

Quanto à dispersão do produto no meio aquífero, foi possível notar que apenas o conjunto de poços relacionados ao ponto de injeção RW-02 apresentou efetivo acesso do produto aos poços a jusante. Este fato pode ser atribuído às heterogeneidades locais do meio, assim como alguma influência da viscosidade relativamente elevada da solução injetada.

Considerando a degradação e abatimento de massa da soma dos compostos orgânicos clorados analisados (VOCs totais), foi possível notar que apesar das variações apresentadas nos primeiros meses do monitoramento de desempenho, não houve redução significativa de VOCs totais quando comparados à caracterização inicial.

Quanto à degradação dos principais contaminantes, notou-se que nos poços onde foi efetivo o acesso do produto injetado (principalmente no conjunto do RW-02) não houve redução significativa dos contaminantes quando se compara os resultados da caracterização inicial com a da última análise do monitoramento de desempenho, onze meses após a injeção. Ainda dentro dessa abordagem observou-se que para o RW-02, assim como para dois de seus poços de jusante (MW-301 e MW-302), ocorreu aumento das concentrações do composto cloreto de vinila. Este aumento se torna um indício de que as reações esperadas não ocorreram, uma vez que de acordo com o método, deveria se observar a eliminação de dois cloretos por vez, minimizando o aumento de compostos filhos mais nocivos. 
Quanto à produção de ferro bivalente dissolvido pela reação esperada, foi notado aumento significativo das concentrações de ferro bivalente dissolvido apenas na última campanha de monitoramento (onze meses após injeção). Também se nota que anteriormente ao ferro bivalente dissolvido, ocorreu um aumento significativo das concentrações de sulfato. Embora este último seja um dos produtos da reação esperada, a sua aparição não concomitante ao aumento de ferro bivalente dissolvido pode indicar que outras reações ocorreram paralelamente. Dessa forma, é bastante provável que parte do produto tenha sido consumido sem ter efetivamente contribuído com o aumento de ferro bivalente dissolvido.

Quanto à ocorrência da reação de degradação esperada quando da presença de ferro bivalente dissolvido, foi possível observar que ainda quando presente em proporção molar superior aos contaminantes, o ferro não foi eficaz na degradação, uma vez que não foi obtida redução significativa. A não redução dos contaminantes nesse caso pode indicar que a reação de degradação esperada não ocorreu, que houve interferência devido à reações físico-químicas ocorridas com a presença do produto, ou que a cinética da reação foi lenta o suficiente para não ser observada pelo período de onze meses de monitoramentos.

Com base nos resultados deste teste piloto, pode-se afirmar que o método de remediação não se apresentou eficiente para ser aplicado na escala da área de estudo para o tratamento de todas as plumas de contaminação.

\subsection{INJEÇÃO DO OXIDANTE EM ESCALA DE REMEDIAÇÃO}

As campanhas de monitoramento da água subterrânea realizadas antes e após as atividades de injeção avaliaram o comportamento do principal contaminante presente no aquífero freático em relação à presença do oxidante injetado em toda a área impactada. Os resultados indicaram que a remediação tanto do topo, quanto da base do aquífero freático foi efetiva, portanto houve o contato direto do permanganato de potássio com 0 organoclorado 1,1-DCE. Isto porque, de todos os poços de monitoramento investigados após as atividades de injeção, apenas um apresentou concentração do contaminante acima da meta de remediação calculada para a área. Assim, entende-se que a remediação foi efetiva em todo o aquífero freático, onde se encontra o manto de intemperismo, sobreposto à camada de aquitarde encontrada na área.

A avaliação dos potenciais efeitos colaterais, relacionados à alterações geoquímicas do meio, normalmente ocorridos em áreas onde a remediação química é a metodologia de tratamento de uma área contaminada, foi comprometida, já que não foram possíveis as realizações de análises de metais e as medições em campo de parâmetros físico-químicos de pontos onde havia a indicação da presença do oxidante. Ainda assim, 
com base nos dados obtidos, foi possível notar um aumento nas concentrações de metais como, alumínio, bário e ferro. A campanha de monitoramento de outubro de 2009 (quinze meses após a injeção) mostrou um brusco aumento da concentração de manganês na amostragem de outubro de 2009 (quinze meses após as atividades de injeção). Na amostragem seguinte em maio de 2010 (vinte e dois meses após as atividades) observou-se uma diminuição considerável das concentrações deste composto assim, como dos demais metais. Isso indicou o período de consumo do permanganato de potássio mais intenso, onde passou a ocorrer a precipitação deste composto como dióxido de manganês.

O consumo completo do permanganato pelo contaminante deverá resultar no retorno das características geoquímicas do aquífero semelhantes às observadas anteriormente às atividades de injeção do permanganato de potássio, o que potencialmente facilitará a precipitação dos metais e conseqüente diminuição das concentrações de metais.

\section{REFERÊNCIAS BIBILIOGRÁFICAS}

ALMEIDA, F. F. M.; BARBOSA, O (1953), Geologia das quadrículas de Piracicaba e Rio Claro. Bol. Div. Geol. Min., Rio de Janeiro, DNPM, (1943): 1-96.il.

AMARAL, S. E. (1971), Geologia e petrologia da Formação Irati (permiano) no Estado de São Paulo, Bol. Inst. Geoc. Astron., São Paulo, (2):3-82.

ANDRADE, S. M.; SOARES, P. C. (1971), Geologia de semi-detalhe do centro-leste do Estado de São Paulo. Ponta Grossa, Petrobrás. (Relatório interno, DESUL, 407).

ARNOLD, W. A.; ROBERTS, A. J. (2000), Pathways and kinetics of chlorinated ethylene and chlorinated acetylene reaction with $\mathrm{Fe}(0)$ particles. Environmental Science and Technology 34, 1794-1805.

ASSOCIAÇÃO BRASILEIRA DE NORMAS TÉCNICAS. Poços de monitoramento de água subterrâneas em aqüíferos granulares - NBR 15495-1:2007. ABNT, 2007, 33p.

BARBOSA, O.; ALMEIDA, F. F. M. (1949), A série Tubarão da bacia do Rio Tietê, Estado de São Paulo. Notas Prelim. Est. Div. Geol. Min., Rio de Janeiro, DNPM, (40): 1-16.

BARBOSA, O.; GOMES, F. A. (1958), Pesquisa de petróleo na bacia do Rio Corumbataí, Estado de São Paulo. Bol. Div. Geol. Min., Rio de Janeiro, DNPM, (171): 1-40.

BROWN, R. A., LEWIS, A. L. (2005), In situ chemical reduction an evolving technology. ConSoil 2005, Bordeaux, France.

BROWN, R. A. et al. (2006), The technical basis for in situ chemical reduction (ISCR). Fifth International Conference on Remediation of Chlorinated and Recalcitrant Compounds, Monterey, CA.

BUSCHECK, T. E.; ALCANTAR, C. M. (1995), Regression techniques and analytical solutions to demonstrate intrinsic bioremediation, Proceeding of the Battelle In Situ and On-Site Bioremediation Symposium, April 24-27, 1995, San Diego, CA.

\section{CENTRE FOR ECOLOGICAL SCIENCES}

http://www.ces.iisc.ernet.in/energy/HC270799/HDL/ENV/enven/vol369.htm. Acesso em 16 de fevereiro de 2010.

CHEMFINDER - http://chembiofinder.cambridgesoft.com/chembiofinder/SimpleSearch.aspx. 
Acesso em 20 de junho de 2009.

CHEMICAL BOOK -

http://www.chemicalbook.com/ChemicalProductProperty EN CB7325193.htm. Acesso em 20 de junho de 2009.

COMPANHIA AMBIENTAL DO ESTADO DE SÃO PAULO - CETESB (2009), Cadastro de áreas contaminadas e reabilitadas no Estado de São Paulo http://www.cetesb.sp.gov.br/Solo/areas contaminadas/texto areas cont nov 09 .pdf. Acesso em 06 de julho de 2010.

CHEMBURKAR, A., WARNER, J., SKLADANY, G. J., BROWN, R. A. (2006), Use of chemical reductants to stimulate abiotic reductive pathways. Fifth International Conference on Remediation of Chlorinated and Recalcitrant Compounds, Monterey, CA.

CRIMI, M. L.; SIEGRIST, R. L. (2003), Geochemical Effects on Metals Following Permanganate Oxidation of DNAPLs. Ground Water, v. 41, No. 4, 458-469.

DEPARTAMENTO DE ÁGUAS E ENERGIA ELÉTRICA (DAEE), INSTITUTO GEOLÓGICO (IG), INSTITUTO DE PESQUISAS TECNOLÓGICAS DO ESTADO DE SÃO PAULO (IPT), SERVIÇO GEOLÓGICO DO BRASIL (CPRM) (2005), Mapa de águas subterrâneas do Estado de São Paulo, escala 1:1.000.000, nota explicativa - São Paulo.

DEPARTMENT OF ENERGY - DOE (1999), In situ chemical oxidation using potassium permanganate, Piketon, Ohio, United States (DOE/EM-0496).

DEPARTMENT OF ENVIRONMENTAL PROTECTION http://www.dep.state.pa.us/physicalproperties/CPP Search.htm. Acesso em 20 de junho de 2009.

DEPARTAMENTO DE ESTRADAS E RODAGEM (2009), Mapa rodoviário do Estado de São Paulo, Governo do Estado de São Paulo, Secretaria do Estado dos transportes.

ENVIRONMENTAL RESOURCES MANAGEMENT - ERM (2009), Oxidação química in situ - Implementação e operação do sistema full scale e monitoramento (0076129).

FERRAZ, F.F.B.; MORTATTI, J. (2003), Análise da relação entre a distribuição espacial da precipitação e os componentes do escoamento em bacia tropical de mesoescala. Revista GEOUSP. São Paulo, V.13, (http://www.geografia.fflch.usp.br/ /publicacoes/geousp/Geousp13/Geousp13_Ferraz_Mortatti.htm)

HØNNING, J. (2007), Use of in situ chemical oxidation with permanganate in PCEcontaminated clayey till with sand lenses. Ph.D. Thesis, Institute of Environment \& Resources Technical University of Denmark.

HU G. J.; CHOU, R. (2002), Pilot test using potassium permanganate solution for VOCsimpacted groundwater cleanup. Third International Conference on Remediation of Chlorinated and Recalcitrant Compounds, Monterey, CA.

INSTITUTO DE PESQUISAS TECNOLÓGICAS DO ESTADO DE SÃO PAULO (1981). Mapa geológico do Estado de São Paulo. São Paulo, IPT. v.1. Escala 1: 500.000.

INSTITUTO DE PESQUISAS TECNOLÓGICAS DO ESTADO DE SÃO PAULO (1981). Mapa geomorfológico do Estado de São Paulo. São Paulo, IPT. v.1. Escala 1: 500.000 .

KEELEY, A. A.; RUSSELL, H. H.; SEWELL, G. W. (1999), Microbial Processes Affecting Monitored Natural Attenuation of Contaminants in the Subsurface, United States Environmental Protection Agency, EPA/540/S-99/001.

LANDIM, P. M. B. (1970), O Grupo Passa Dois (P) na Bacia do Rio Corumbataí (SP), Bol. 
Div. Geol. Min., Rio de Janeiro, DNPM, (252): 1-103. il.

LEE, M., LIBERMAN, T., BECKWITH, W., BORDEN, R. (2002), Pilots to enhance trichloroethene reductive dechlorination and ferrous sulphide abiotic transformation. Third International Conference on Remediation of Chlorinated and Recalcitrant Compounds, Monteret, CA.

MARVIN, B. K.; CHAMBERS, J.; LEAVITT, A. (2002), Chemical and Engineering challenges to in situ permanganate remediation. Third International Conference on Remediation of Chlorinated and Recalcitrant Compounds, Monterey, CA.

MENDES, J. C. (1952b), A Formação Corumbataí na região do Rio Corumbataí, estratigrafia e descrição dos lamelibrânquios. Bol. Fac. Ci e Letras, São Paulo, (145): 1-119.il. (Geologia 8).

MEZZALIRA, S. (1957), Ocorrências fossilíferas novas na série Passa Dois na Região de Limeira, Rio Claro, Piracicaba, São Paulo, 6(2):37-58.

MUEGGE, J. (2008), Na assessment of zero valence iron. Permeable reactive barrier projects in Califórnia, Office of Pollution Prevent and Technology Development California Department of Toxic Substances Control, California, United States (Document $n^{\circ}$ 1219).

OLIVEIRA et. al, (1999), Mapa pedológico do Estado de São Paulo EMBRAPA / IAC, 1999, São Paulo. Escala 1: 500.000.

PANKOV, J. F.; CHERRY, J. A. (1996), Dense chlorinated solvents and other DNAPLs in groundwater, Ontario, Canada.

PEREIRA, S, Y; SILVA, A. A. K. (1997), Condições de ocorrência das águas subterrâneas e do potencial produtivo dos sistemas aqüíferos na região metropolitana de CampinasSP. Rev. IG, São Paulo, 18 (1/2), 23-40, jan/dez/1997.

ROCHA, G.; FERNANDES, A.J. (2005). O mapa. In: ROHA, G.; FERNANDES, A.J.; MANCUSO, M., Mapa de águas subterrâneas do Estado de São Paulo, DAEE/IG/CPRM/IPT, São Paulo.

RISK ASSESSMENT INFORMATION SYSTEM - http://rais.ornl.gov/cgi-bin/tox/TOX select. Acesso em 20 de junho de 2009.

SCHNEIDER, R. L.; MUHLMANN, H. E.; MEDEIROS, R. A.; DAEMON, R. F.; NOGUEIRA, A. A. (1974), Revisão estratigráfica da Bacia do Paraná. In: CONGRESSO BRASILEIRO DE GEOLOGIA, 28, Porto Alegre, 1974. Anais. Porto Alegre, SBG. v.1, p.41-65.

SOARES, P. C. (1972b), O limite glacial-pós-glacial do Grupo Tubarão no Estado de São Paulo. An. Acad. Brás. Ci., Rio de Janeiro, 44(supl.): 333-341.

SRC - http://www.srcinc.com/what-we-do/databaseforms.aspx?id=386. Acesso em 20 de junho de 2009.

SUTHERSAN, S. S.; PAYNE, F. C. (2005), In Situ Remediation Engineering, Washington, DC, United States of America

SZECSODY, F. E., FRUCHTER, H. S., WILLIAMS, M. D., VERMUEL, V. R., SKLAREW, D, (2004), In situ chemical reduction of aquifer sediments: enhancement of reactive iron phases and TCE dechlorination. Environmental Science and Technology 38, 46564663.

TIEDJE, J. M.; MOHN, W. W, (1992), Microbial reductive dehalogenation microbiological reviews, Vol. 56, No. 3 P. 482-507.

UNITED STATES ENVIRONMENTAL PROTECTION AGENCY - EPA (1998), Technical protocol for evaluating natural attenuation of chlorinated solvents in ground water, 
Washington DC, United States (EPA/600/R-98/128).

UNITED STATES ENVIRONMENTAL PROTECTION AGENCY - EPA (2004), Monitored Natural Attenuation, United States (EPA/510/R-04-002).

UNITED STATES ENVIRONMENTAL PROTECTION AGENCY - EPA (2008), Chemical Oxidation Guidance, Illinois, United States.

UNITED STATES ENVIRONMENTAL PROTECTION AGENCY -

http://cfpub.epa.gov/ncea/iris/index.cfm?fuseaction=iris.showSubstanceList. Acesso em 20 de junho de 2009.

VERMUEL, V. R., WILLLIAMS, M. D., EVANS, J. C., SZECSODY, J. E., BJORNSTAD, B. N., LIIKALA, T. L., (2000), In situ redox manipulation proof-of-principle test at the Fort Lewis Logistics Center: final report. Pacific Northwest National Laboratory, Richland, Washington 99352 (PNNL - 13357).

VOGEL, T. M., CRIDDLE, C.S., McCARTY, P. L., (1987), Transformations of halogenated aliphatic compounds, Environmental Science and Technology. 21, 722-736.

VOGEL, T. M., McCARTY, P. L., (1987), Abiotic and biotic transformations of 1,1,1-TCA under methanogenic conditions. Environ Sci. Technol. 21, 1208-1213.

WASHBURNE, C. W. (1930), Petroleum geology of the state of São Paulo - Brazil. Bol. Com Geogr. Geol., São Paulo, (22):1-282.il 
ANEXO 1 PERFIS CONSTRUTIVOS 


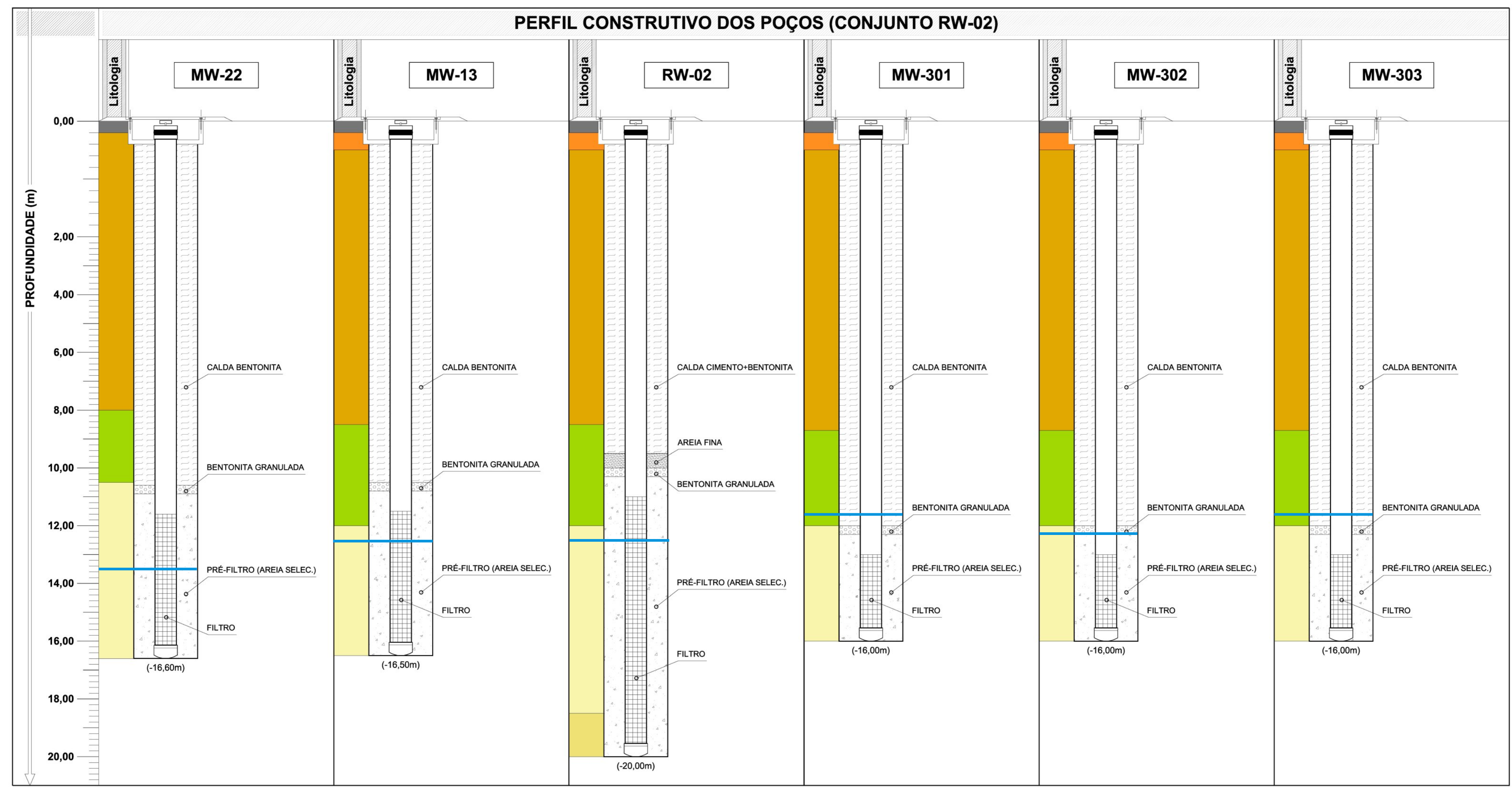

\section{LEGENDA}

Aterro: Predomínio de argila silto-arenosa, observa-se localmente entulho e raizes, apresenta coloraçăo marrom a vermelho.

Manto de intemperismo: Silte argiloso, com presença de areia fina, estruturas de lam haçao, alta plasilidade, com coloração branca, roxa, vermelha, e cinza

amarelada.

Manto de intemperismo: Areia fina siltosa pouco argilosa, de baixa apresenta cor marrom avermelhada.

Rocha sã muito alterada: Silte arenoso (areia fina), compacto, com presença local de planos de fraturamento (preenchidos) com inclinação acentuada. Apresenta coloraçãa
predominantemente amarelada, porém com ocorrência de porções de cor roxa.

Manto de intemperismo: Areia fina argilosa com presença de silte na matriz, 


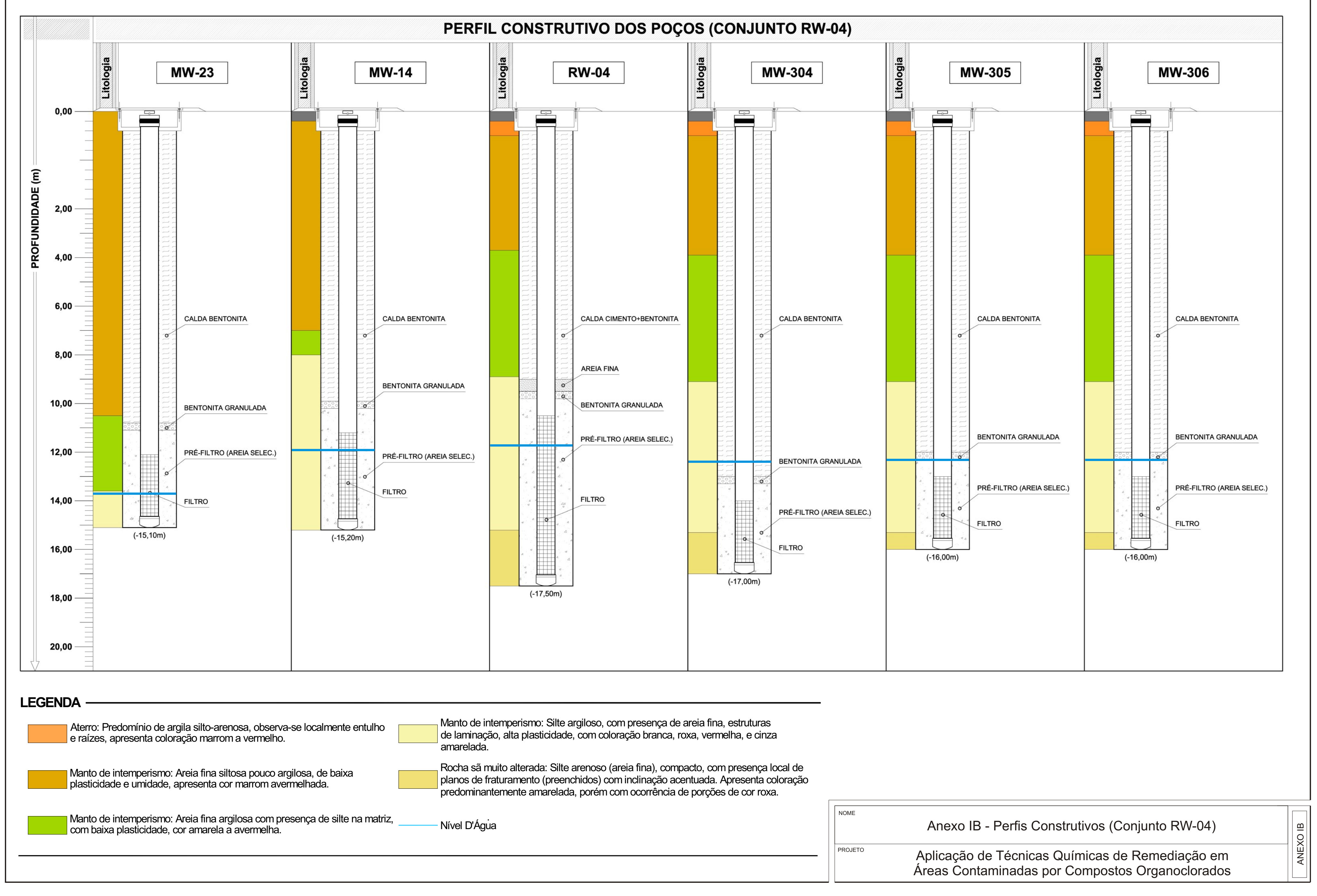




\section{ANEXO 2 ANÁLISES QUIIMICAS}


Anexo 2A-1 - Resultados das análises de VOCs dos Tanques de Injeção

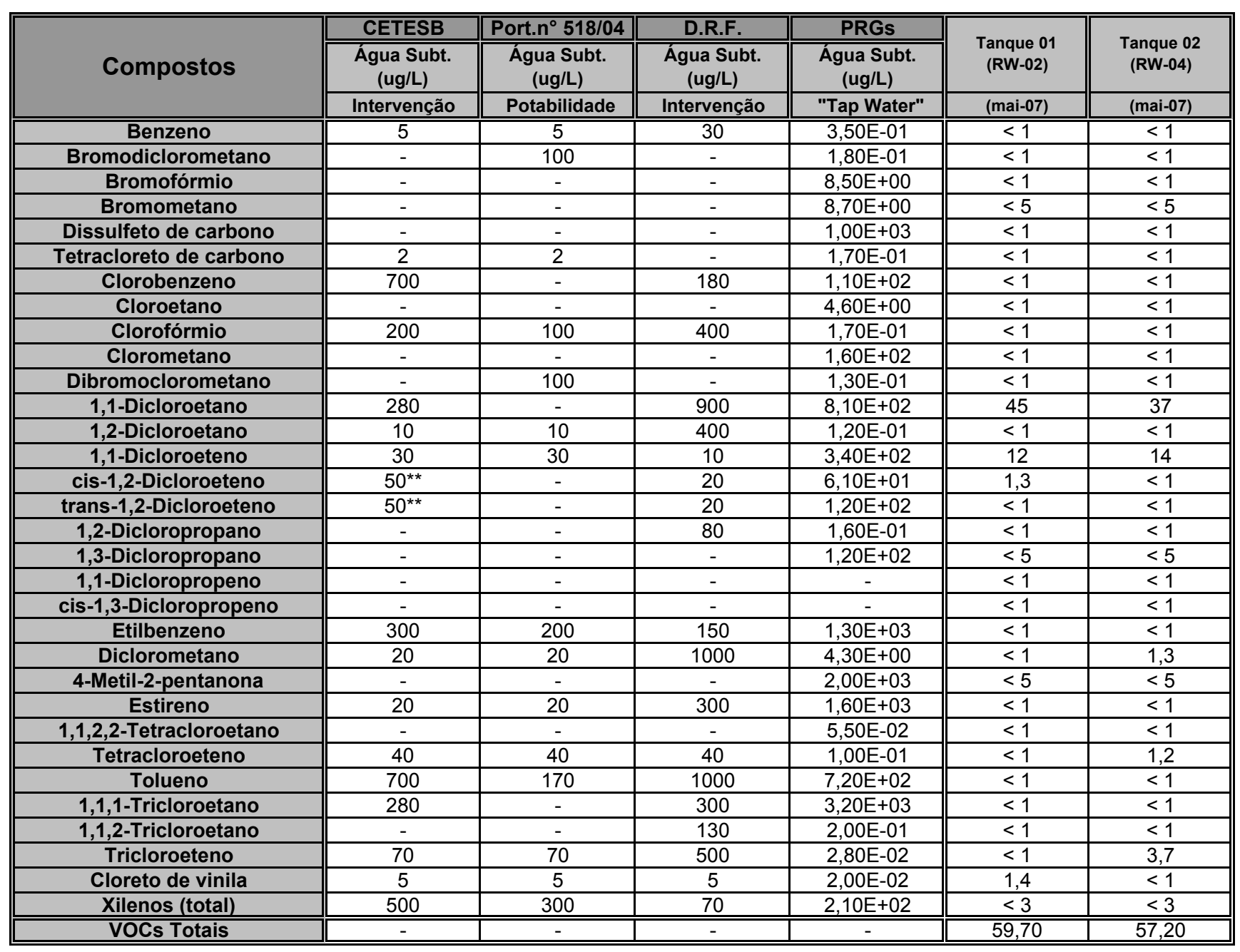

Portaria $\mathrm{n}^{\circ}$ 518/04: Padrão de Potabilidade estabelecido pelo Minitério da Saúde

CETESB: Companhia de Tecnologia de Saneamento Ambiental

D.R.F.: Dutch Reference Framework

PRGs: Preliminary Remediation Goals (Region IX) 
Anexo 2A-2 - Resultados das análises de VOCs (conjunto RW-02)

\begin{tabular}{|c|c|c|c|c|c|c|c|c|c|c|c|c|c|c|c|c|c|c|c|}
\hline \multirow{3}{*}{ Compostos } & \multirow{3}{*}{$\begin{array}{l}\text { Átua Subt. } \\
\text { (ug/L) } \\
\text { Intervencão }\end{array}$} & \multirow{2}{*}{\begin{tabular}{|c|} 
Port.n ${ }^{\circ} 518 / 04$ \\
$\begin{array}{c}\text { Agua Subt. } \\
\text { (ugl/L) }\end{array}$
\end{tabular}} & \multirow{2}{*}{$\begin{array}{l}\text { D.R.F. } \\
\begin{array}{c}\text { Agua Subt. } \\
\text { (ug/L) }\end{array} \\
\end{array}$} & \multirow{2}{*}{$\begin{array}{l}\text { PRGs } \\
\begin{array}{c}\text { Agua Subt. } \\
\text { (ug/L) }\end{array} \\
\end{array}$} & MW 23 & MW 23 & MW 23 & MW 23 & MW 23 & \multirow{2}{*}{ MW-13 } & \multirow[t]{2}{*}{ MW 13} & \multirow{2}{*}{$\begin{array}{l}\text { MW } 13 \\
3^{\circ} \text { mês }\end{array}$} & \multirow{2}{*}{$\begin{array}{l}\text { MW } 13 \\
6^{\circ} \text { mês }\end{array}$} & \multirow{2}{*}{$\begin{array}{r}\text { MW } 13 \\
11^{\circ} \text { mês } \\
\end{array}$} & \multirow{3}{*}{\begin{tabular}{|c|} 
RW-02 \\
C. Inicial \\
(mar-07) \\
\end{tabular}} & \multirow{3}{*}{$\begin{array}{c}\text { RW-02 } \\
1^{\circ} \text { mês } \\
\text { (iul-07) }\end{array}$} & \multirow{3}{*}{\begin{tabular}{|c|} 
RW-02 \\
$3^{\circ}$ mês \\
(set-07)
\end{tabular}} & \multirow{3}{*}{$\begin{array}{c}\text { RW-02 } \\
6^{\circ} \text { mês } \\
\text { (dez-07) }\end{array}$} & \multirow{2}{*}{\begin{tabular}{|r|} 
RW-02 \\
$11^{\circ}$ mês \\
\end{tabular}} \\
\hline & & & & & C. Inicial & $1^{\circ}$ mês & $3^{\circ}$ mês & $6^{\circ}$ mês & $11^{\circ}$ mês & & & & & & & & & & \\
\hline & & & & & (mar-07) & (jul-07) & $\begin{array}{l}\text { (set-07) } \\
\text { (se }\end{array}$ & (dez-07) & (mai-08) & (mar-07) & $\begin{array}{l}\text { (jul-07) } \\
\end{array}$ & (set-07) & \begin{tabular}{|l|l|} 
(dez-07) \\
\end{tabular} & (mai-08) & & & & & (mai-08) \\
\hline Benzeno & 5 & 5 & 30 & $3,50 \mathrm{E}-01$ & 1 & 1,3 & $\frac{1}{<<1}$ & $\begin{array}{ll}1,4 \\
1,4\end{array}$ & 1,4 & $<1$ & $\frac{1}{2<1}$ & \begin{tabular}{c|c|}
$<<1$ \\
$<1$
\end{tabular} & $<<1$ & $<1$ & $<<1$ & $<1$ & $\frac{11}{<<1}$ & \begin{tabular}{ll|}
$<<1$ \\
\end{tabular} & $<1$ \\
\hline Bromodiclorometano & - & 100 & - & $1,80 \mathrm{E}-01$ & $<1$ & $<1$ & $<1$ & $<1$ & $<1$ & $<1$ & $<1$ & $<1$ & $<1$ & $<1$ & $<1$ & $<1$ & $<1$ & $<1$ & $<1$ \\
\hline Bromofórmio & - & & - & $8,50 E+00$ & $<1$ & $\begin{array}{c}<1 \\
\end{array}$ & $\begin{array}{c}<1 \\
\end{array}$ & $<1$ & $<1$ & $<1$ & $<1$ & $<1$ & $<1$ & $<1$ & $<1$ & $<1$ & $<1$ & $<1$ & $<1$ \\
\hline & - & - & - & & & $<5$ & $<5$ & $<5$ & $<5$ & & $<5$ & & $<5$ & $<1$ & $<5$ & & $<5$ & $<5$ & \\
\hline Dissulfeto de carbono & 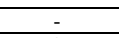 & - & - & $1,00 E+03$ & $<1$ & $<1$ & $<1$ & $<1$ & $<1$ & $<1$ & $<1$ & $<1$ & $<1$ & $<1$ & $<1$ & 3,6 & $<1$ & 11 & 6,6 \\
\hline Tetracloreto de carbono & 2 & 2 & 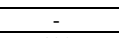 & $1,70 \mathrm{E}-01$ & $<1$ & $<1$ & $<1$ & $<1$ & $<1$ & $<1$ & $<1$ & $<1$ & $<1$ & $<1$ & $<1$ & $\frac{10}{<1}$ & $<1$ & $<1$ & $<1$ \\
\hline Clorobenzeno & 700 & & 180 & $1,10 \mathrm{E}+02$ & $<1$ & $<1$ & $<1$ & $<1$ & $<1$ & $<1$ & $<1$ & $<1$ & $<1$ & $<1$ & $<1$ & $<1$ & $<1$ & $<1$ & $<1$ \\
\hline Cloroetano & & & & $4,60 \mathrm{E}+00$ & 61 & 82 & 34 & 66 & 23 & 291 & 135 & 17 & 55 & 44 & 3 & 115 & 39 & 36 & 25 \\
\hline Clorofórmio & 200 & 100 & 400 & $1,70 \mathrm{E}-01$ & 6,5 & 6,5 & 4 & 6,9 & 7,4 & 2,3 & $<1$ & 1,2 & 1,1 & 1 & 2,6 & $<1$ & 1 & 10 & $<1$ \\
\hline Clorometano & - & & , & $1,60 \mathrm{E}+02$ & $<1$ & $<1$ & $<1$ & $<10$ & $<10$ & $<1$ & $<1$ & $<1$ & $<10$ & $<10$ & $<1$ & $<1$ & $<1$ & $<10$ & $<10$ \\
\hline Dibromoclorometano & & 100 & $-1,2>$ & $1,30 \mathrm{E}-01$ & $<1$ & $<1$ & $<1$ & $<1$ & $<1$ & $<1$ & $<1$ & $<1$ & $<1$ & $<1$ & $<1$ & $<1$ & $<1$ & $<1$ & $<1$ \\
\hline 1,1-Dicloroetano & 280 & & 900 & $8,10 \mathrm{E}+02$ & 2370 & 4800 & 1780 & 4310 & 3510 & 310 & 978 & 234 & 696 & 543 & 336 & 3450 & 1175 & 1530 & 1810 \\
\hline 1,2-Dicloroetano & 10 & 10 & 400 & $1,20 \mathrm{E}-01$ & 5,3 & 7,4 & 7 & 6,4 & 6,6 & 2,6 & 5,3 & 1,8 & 3,2 & 4,7 & $<1$ & 10 & 7,4 & 12 & 13 \\
\hline 1,1-Dicloroeteno & 30 & 30 & 10 & $3,40 \mathrm{E}+02$ & 745 & 2200 & 496 & 2058 & 1640 & 20 & 145 & 31 & 118 & 105 & 27 & 1750 & 242 & 349 & 406 \\
\hline cis-1,2-Dicloroeteno & $50^{* *}$ & & 20 & $6,10 \mathrm{E}+01$ & 106 & 138 & 58 & 179 & 132 & 16 & 34 & 13 & 25 & 23 & 15 & 126 & 56 & 71 & 63 \\
\hline trans-1,2-Dicloroeteno & $50^{* *}$ & - & 20 & $1,20 \mathrm{E}+02$ & 6,6 & 14 & 4,9 & 14 & 14 & 1,5 & 3,4 & $<1$ & 1,9 & 2,3 & $<1$ & 12 & 3,6 & 8 & 6,6 \\
\hline 1,2-Dicloropropano & & - & 80 & $1,60 \mathrm{E}-01$ & $<1$ & $<1$ & $<1$ & $<1$ & $<1$ & $<1$ & $<1$ & $<1$ & $<1$ & $<1$ & $<1$ & $<1$ & $<1$ & $<1$ & $<1$ \\
\hline 1,3-Dicloropropano & & - & & $1,20 \mathrm{E}+02$ & $<5$ & $<5$ & $<5$ & $<5$ & $<5$ & $<5$ & $<5$ & $<5$ & $<5$ & $<5$ & $<5$ & $<5$ & $<5$ & $<5$ & $<1$ \\
\hline 1,1-Dicloropropeno & - & - & - & - & $<1$ & $<1$ & $<1$ & $<1$ & $<1$ & $<1$ & $<1$ & $<1$ & $<1$ & $<1$ & $<1$ & $<1$ & $<1$ & $<1$ & $<1$ \\
\hline cis-1,3-Dicloropropeno & & & & & $<1$ & $<1$ & $<1$ & $<1$ & $<1$ & $<1$ & $<1$ & $<1$ & $<1$ & $<1$ & $<1$ & $<1$ & $<1$ & $<1$ & $<1$ \\
\hline Etilbenzeno & 300 & 200 & 150 & $1,30 \mathrm{E}+03$ & $<1$ & $<1$ & $<1$ & $<1$ & $<1$ & 2,2 & 2,3 & $<1$ & 1,6 & 1,1 & $<1$ & 4 & 1,3 & 3,6 & 2,3 \\
\hline Diclorometano & 20 & 20 & 1000 & $4,30 \mathrm{E}+00$ & 2,5 & 8,5 & 10 & $<1$ & 4,7 & $<1$ & $<1$ & $<1$ & $<1$ & $<1$ & $<1$ & 12 & $<1$ & $<1$ & 2 \\
\hline 4-Metil-2-pentanona & & & sen & $2,00 E+03$ & $<5$ & $<5$ & $<5$ & $<5$ & $<5$ & $<5$ & $<5$ & $<5$ & $<5$ & 25 & $<5$ & 7,5 & $<5$ & $<5$ & $<5$ \\
\hline Estire & 20 & 20 & 300 & $1,60 E+03$ & $<1$ & $<1$ & $<1$ & $<1$ & $<1$ & $<1$ & $<1$ & $<1$ & $<1$ & $<1$ & $<1$ & $<1$ & $<1$ & $<1$ & $<1$ \\
\hline 1,1,2,2-Tetracloroetano & & - & & $5,50 \mathrm{E}-02$ & $<1$ & $<1$ & $<1$ & $<1$ & $<1$ & $<1$ & $<1$ & $<1$ & $<1$ & $<1$ & $<1$ & $<1$ & $<1$ & $<1$ & $<1$ \\
\hline Tetracloroeteno & 40 & 40 & 40 & $1,00 \mathrm{E}-01$ & 68 & 41 & 14 & 89 & 76 & 24 & 6,5 & 6,6 & 21 & $\pi 1$ & 41 & 24 & 3,5 & 13 & 6,9 \\
\hline Toluer & 700 & 170 & 1000 & $7,20 E+02$ & $<1$ & $<1$ & $<1$ & $<1$ & $<1$ & $<1$ & 1,3 & $<1$ & $<1$ & $<1$ & $<1$ & 2,1 & $<1$ & 1,1 & 1,1 \\
\hline 1,1,1-Tricloroetano & 280 & & 300 & $3,20 E+03$ & 5,6 & 2 & $<1$ & 2 & 1,7 & 5,5 & 1,8 & $<1$ & 1,5 & 1,8 & 5,9 & 1,5 & $<1$ & $<1$ & $<1$ \\
\hline 1,1,2-Tricloroetano & & & 130 & $2,00 \mathrm{E}-01$ & 78 & 98 & 53 & 111 & 96 & 14 & 27 & 15 & 20 & 11 & 11 & 61 & 61 & 68 & 44 \\
\hline Tricloroeteno & 70 & 70 & 500 & $2,80 \mathrm{E}-02$ & 49 & 45 & 16 & 75 & 53 & 17 & 13 & 5,5 & 17 & 1 & 16 & 33 & 7,7 & 21 & 15 \\
\hline Cloreto de vinila & 5 & 5 & 5 & $2,00 \mathrm{E}-02$ & 8,2 & 19 & 2 & 13 & 9,3 & 226 & 160 & 25 & 261 & 162 & 2,7 & 151 & 79 & 433 & 295 \\
\hline Xilenos (total) & 500 & 300 & 70 & $2,10 \mathrm{E}+02$ & $<3$ & $<3$ & $<3$ & $\leq 3$ & $<3$ & 10,6 & 10,6 & 3,1 & 6,8 & 2,4 & $<3$ & 15,9 & 3,8 & 10,3 & 6,2 \\
\hline VOCs Totais & - & - & - & - & 3512,70 & 7462,70 & 2478,90 & $\begin{array}{l}6931,70 \\
\end{array}$ & 5575,10 & 942,7 & 1523,2 & 353,2 & 1229,1 & 937,3 & 460,2 & 5778,6 & 1680,3 & 2577 & 6,2 \\
\hline
\end{tabular}

Portaria n` $518104:$ Padrão de Potabilidade estabelecido pelo Minitério da Saúde

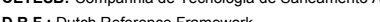

PRGs: Preliminary Remediation Goals (Region IX) 
Anexo 2A-2 - Resultados das análises de VOCs (conjunto RW-02)

\begin{tabular}{|c|c|c|c|c|c|c|c|c|c|c|c|c|c|c|c|c|c|c|c|}
\hline \multirow{3}{*}{ Compostos } & \multirow{3}{*}{$\begin{array}{l}\text { Átua Subt. } \\
\text { (ug/L) } \\
\text { Intervencão }\end{array}$} & \multirow{2}{*}{\begin{tabular}{|c|} 
Port.n ${ }^{\circ} 518 / 04$ \\
$\begin{array}{c}\text { Agua Subt. } \\
\text { (ugl/L) }\end{array}$
\end{tabular}} & \multirow{2}{*}{$\begin{array}{l}\text { D.R.F. } \\
\begin{array}{c}\text { Agua Subt. } \\
\text { (ug/L) }\end{array} \\
\end{array}$} & \multirow{2}{*}{$\begin{array}{l}\text { PRGs } \\
\begin{array}{c}\text { Agua Subt. } \\
\text { (ug/L) }\end{array} \\
\end{array}$} & MW 301 & MW 301 & MW 301 & MW 301 & MW 301 & MW 302 & MW 302 & \multirow{2}{*}{$\begin{array}{l}\text { MW } 302 \\
3^{\circ} \text { mês }\end{array}$} & \multirow{2}{*}{\begin{tabular}{|l|} 
мw 302 \\
$6^{\circ}$ mês \\
\end{tabular}} & \multirow{2}{*}{$\begin{array}{l}\text { MW } 302 \\
11^{\circ} \text { mês } \\
\end{array}$} & \multirow{3}{*}{\begin{tabular}{|l|} 
мW 303 \\
C. Inicial \\
(mar-07) \\
\end{tabular}} & \multirow{3}{*}{$\begin{array}{l}\text { MW } 303 \\
1^{\circ} \text { mês } \\
\text { (jul-07) }\end{array}$} & \multirow{3}{*}{\begin{tabular}{|l|} 
MW 303 \\
$3^{\circ}$ mês \\
(set-07) \\
\end{tabular}} & \multirow{3}{*}{$\begin{array}{l}\text { MW } 303 \\
6^{\circ} \text { mês } \\
\text { (dez-07) }\end{array}$} & \multirow{2}{*}{\begin{tabular}{|l|} 
MW 303 \\
$11^{\circ}$ mês \\
\end{tabular}} \\
\hline & & & & & C. Inicial & $1^{\circ}$ mês & $3^{\circ}$ mês & $6^{\circ}$ mês & $11^{\circ}$ mês & \begin{tabular}{|l|} 
C. Inicial \\
\end{tabular} & $1^{\circ}$ mês & & & & & & & & \\
\hline & & & & & (mar-07) & (jul-07) & $\begin{array}{l}\text { (set-07) } \\
\end{array}$ & (dez-07) & (mai-08) & (mar-07) & (jul-07) & (set-07) & (dez-07) & (mai-08) & & & & & (mai-08) \\
\hline Benzeno & 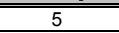 & 5 & 30 & $\begin{array}{l}3,50 \mathrm{E}-01 \\
\end{array}$ & $<1$ & $<1$ & $<<1$ & $<1$ & $<1$ & $<1$ & $<1$ & $<1$ & $<<1$ & $<<1$ & $<<1$ & $<1$ & $<<1$ & $<1$ & $<1$ \\
\hline Bromodiclorometano & - & 100 & - & $1,80 \mathrm{E}-01$ & $<1$ & $<1$ & $<1$ & $<1$ & $<1$ & $<1$ & $<1$ & $<1$ & $<1$ & $<1$ & $<1$ & $<1$ & $<1$ & $<1$ & $<1$ \\
\hline Bromofórmio & - & & - & $8,50 \mathrm{E}+00$ & $<1$ & $<1$ & $<1$ & $<1$ & $<1$ & $<1$ & $<1$ & $<1$ & $<1$ & $<1$ & $<1$ & $<1$ & $<1$ & $<1$ & $<1$ \\
\hline Bromometano & - & - & - & $8,70 E+00$ & $<5$ & $<5$ & $<5$ & $<5$ & $<5$ & $<5$ & $<5$ & $<5$ & $<5$ & $<5$ & $<5$ & $<5$ & $<5$ & $<5$ & $<5$ \\
\hline Dissulfeto de carbono & & & - & $1,00 \mathrm{E}+03$ & $<1$ & $<1$ & $<1$ & $<1$ & 1,4 & $<1$ & $<1$ & $<1$ & 2,8 & 3,5 & $<1$ & 1,5 & $<1$ & $<1$ & 2,5 \\
\hline Tetracloreto de carbono & 2 & 2 & & $1,70 \mathrm{E}-01$ & $<1$ & $<1$ & $<1$ & $<1$ & $<1$ & $<1$ & $<1$ & $<1$ & $<1$ & $<1$ & $<1$ & $<1$ & $<1$ & $<1$ & $<1$ \\
\hline Clorobenzeno & 700 & & 180 & $1,10 \mathrm{E}+02$ & $<1$ & $<1$ & $<1$ & $<1$ & $<1$ & $<1$ & $<1$ & $<1$ & $<1$ & $<1$ & $<1$ & $<1$ & $<1$ & $<1$ & $<1$ \\
\hline Cloroetano & & & & $4,60 \mathrm{E}+00$ & $<1$ & 2,1 & 2,5 & 3,9 & 5,8 & 3,8 & $<1$ & $<1$ & $<1$ & $<1$ & 30 & 3,1 & $<1$ & 5,3 & 2,7 \\
\hline Clorofórmio & 200 & 100 & 400 & $1,70 \mathrm{E}-01$ & 2 & 3,5 & 1 & $<1$ & $<1$ & 2,2 & $<1$ & 1,2 & $<1$ & $<1$ & 3,7 & $<1$ & 1,5 & $<1$ & $<1$ \\
\hline Clorometano & - & & , & $1,60 \mathrm{E}+02$ & $<1$ & $<1$ & $<1$ & $<10$ & $<10$ & $<1$ & $<1$ & $<1$ & $<10$ & $<10$ & $<1$ & $<1$ & $<1$ & $<10$ & $<10$ \\
\hline Dibromoclorometano & & 100 & - & $1,30 \mathrm{E}-01$ & $<1$ & $<1$ & $<1$ & $<1$ & $<1$ & $<1$ & $<1$ & $<1$ & $<1$ & $<1$ & $<1$ & $<1$ & $<1$ & $<1$ & $<1$ \\
\hline 1,1-Dicloroetano & 280 & & 900 & $8,10 \mathrm{E}+02$ & 334 & 2270 & 660 & 528 & 628 & 850 & 532 & 208 & 588 & 395 & 2046 & 1120 & 1784 & 1140 & 628 \\
\hline 1,2-Dicloroetano & 10 & 10 & 400 & $1,20 \mathrm{E}-01$ & $<1$ & 5,2 & 2,8 & 3,5 & 6,7 & 1,9 & 1,5 & $<1$ & 3,7 & 2,8 & 7,4 & 3,5 & 3,2 & 8,9 & 5 \\
\hline 1,1-Dicloroeteno & 30 & 30 & 10 & $3,40 \mathrm{E}+02$ & 77 & 601 & 76 & 45 & 138 & 213 & 67 & 21 & 76 & 69 & 516 & 294 & 308 & 57 & 54 \\
\hline cis-1,2-Dicloroeteno & $50^{* *}$ & & 20 & $6,10 \mathrm{E}+01$ & 8,7 & 42 & 16 & 13 & 51 & 16 & 12 & 4,9 & 19 & 14 & 62 & 36 & 55 & 38 & 23 \\
\hline trans-1,2-Dicloroeteno & $50^{* *}$ & - & 20 & $1,20 \mathrm{E}+02$ & $<1$ & 4 & $<1$ & $<1$ & 2,1 & 1,8 & $<1$ & $<1$ & $<1$ & $<1$ & 4,8 & 2,2 & $<1$ & 2,6 & 1,2 \\
\hline 1,2-Dicloropropano & & - & 80 & $\begin{array}{l}1,60 \mathrm{E}-01 \\
\end{array}$ & $<1$ & $<1$ & $<1$ & $<1$ & $<1$ & $<1$ & $<1$ & $<1$ & $<1$ & $<1$ & $<1$ & $<1$ & $<1$ & $<1$ & $<1$ \\
\hline 1,3-Dicloropropano & & & & $1,20 \mathrm{E}+02$ & $<5$ & $<5$ & $<5$ & $<3$ & $<5$ & $<5$ & $<5$ & $<5$ & $<5$ & $<5$ & $<5$ & $<5$ & $<5$ & $<5$ & $<5$ \\
\hline 1,1-Dicloropropeno & - & - & - & - & $<1$ & $<1$ & $<1$ & $<1$ & $<1$ & $<1$ & $<1$ & $<1$ & $<1$ & $<1$ & $<1$ & $<1$ & $<1$ & $<1$ & $<1$ \\
\hline cis-1,3-Dicloropropeno & & & & & $<1$ & $<1$ & $<1$ & $<1$ & $<1$ & $<1$ & $<1$ & $<1$ & $<1$ & $<1$ & $<1$ & $<1$ & $<1$ & $<1$ & $<1$ \\
\hline Etilbenzeno & 300 & 200 & 150 & $1,30 E+03$ & $<1$ & $<1$ & $<1$ & $<1$ & $<1$ & $<1$ & $<1$ & $<1$ & $<1$ & $<1$ & $<1$ & $<1$ & $<1$ & $<1$ & $<1$ \\
\hline Diclorometano & 20 & 20 & 1000 & $4,30 \mathrm{E}+00$ & $<1$ & $<1$ & $<1$ & $<1$ & $<1$ & $<1$ & $<1$ & 36 & $<1$ & $<1$ & $<1$ & $<1$ & $<1$ & $<1$ & $<1$ \\
\hline 4-Metil-2-pentanona & & & sen & $2,00 E+03$ & $<5$ & $<5$ & $<5$ & $<5$ & $<5$ & $<5$ & $<5$ & $<5$ & $<5$ & 25 & $<5$ & $<5$ & $<5$ & $<5$ & $<5$ \\
\hline Estire & 20 & 20 & 300 & $1,60 E+03$ & $<1$ & $<1$ & $<1$ & $<1$ & $<1$ & $<1$ & $<1$ & $<1$ & $<1$ & $<1$ & $<1$ & $<1$ & $<1$ & $<1$ & $<1$ \\
\hline 1,1,2,2-Tetracloroetano & & - & & $5,50 \mathrm{E}-02$ & $<1$ & $<1$ & $<1$ & $<1$ & $<1$ & $<1$ & $<1$ & $<1$ & $<1$ & $<1$ & $<1$ & $<1$ & $<1$ & $<1$ & $<1$ \\
\hline Tetracloroeteno & 40 & 40 & 40 & $1,00 \mathrm{E}-01$ & 22 & 21 & 5,6 & 1,4 & 2,8 & 13 & 14 & 6 & 20 & 12 & 32 & 5,9 & 20 & 1,9 & 2,6 \\
\hline $\begin{aligned} \text { Tolue } \\
11\end{aligned}$ & 700 & 170 & 1000 & $7,20 E+02$ & $<1$ & $<1$ & $<1$ & $<1$ & $<1$ & $<1$ & $<1$ & $<1$ & $<1$ & $<1$ & $<1$ & $<1$ & $<1$ & $<1$ & $<1$ \\
\hline 1,1,1-Tricloroetano & 280 & & 300 & $3,20 E+03$ & 3,9 & 1,8 & $<1$ & $<1$ & $<1$ & 2,9 & 1,6 & $<1$ & $<1$ & $<1$ & 3,4 & 1,4 & $<1$ & $<1$ & $<1$ \\
\hline 1,1,2-Tricloroetano & & & 130 & $2,00 \mathrm{E}-01$ & 8,2 & 58 & 18 & 7,2 & 14 & 19 & 13 & 13 & 17 & 12 & 61 & 29 & 33 & 37 & 16 \\
\hline Tricloroeteno & 70 & 70 & 500 & $2,80 \mathrm{E}-02$ & 9,1 & 19 & 6 & 2,8 & 8,1 & 9,3 & 8,1 & 3,3 & 15 & 8,8 & 24 & 12 & 26 & 5,5 & 3,6 \\
\hline $\begin{array}{l}\text { Cloreto de vinila } \\
\text { Xilenso (total) }\end{array}$ & $\frac{5}{500}$ & $\frac{5}{300}$ & $\frac{5}{70}$ & $\begin{array}{l}2,00 \mathrm{E}-02 \\
12 \mathrm{E}+02 \\
\end{array}$ & $\begin{array}{l}<1 \\
<3\end{array}$ & $\frac{4,6}{33}$ & $\frac{4,4}{<3}$ & $\frac{120}{<3}$ & $\frac{97}{12}$ & $\frac{1,9}{<3}$ & $\frac{1,1}{<3}$ & $\frac{<1}{<3}$ & $\frac{11}{<3}$ & $\frac{3,6}{<3}$ & $\frac{19}{67}$ & $\frac{8,3}{3}$ & $\frac{25}{<3}$ & $\frac{80}{33}$ & $\frac{92}{<3}$ \\
\hline Xilenos (total) & 500 & 300 & 70 & $2,10 \mathrm{E}+02$ & $<3$ & 3,3 & $<3$ & $\leq 3$ & 1,2 & $<3$ & $<3$ & $<3$ & $<3$ & $\angle 3$ & 6,7 & 3 & $<3$ & $\begin{array}{ll}3,3 \\
\end{array}$ & $<3$ \\
\hline VOCs Totais & $-z_{-1}$ & - & - & & 464,9 & 3035,5 & 792,3 & 724,8 & 956,1 & 1134,8 & 650,3 & 293,4 & 752,5 & 520,7 & 2816 & 1519,9 & 2255,7 & 1379,5 & 830,6 \\
\hline
\end{tabular}

Portaria ${ }^{\circ}$ 518/04: Padrão de Potabilidade estabelecido pelo Miniterio da Saúde
CETESB: Companhia de Tecnologia de Saneamento

DRF. D. Compantia de Tecnologla de Sare

PRGs: Preliminary Remediation Goals (Region IX) 
Anexo 2A-3 - Resultados das análises de VOCs do (conjunto RW-04)

\begin{tabular}{|c|c|c|c|c|c|c|c|c|c|c|c|c|c|c|c|c|c|c|c|}
\hline \multirow{3}{*}{ Compostos } & \multirow{3}{*}{$\begin{array}{l}\text { Agua Subt. } \\
\text { (ugl/L) } \\
\text { Intervencão }\end{array}$} & \multirow{2}{*}{$\begin{array}{c}\text { Port.n }{ }^{\circ} 518 / 04 \\
\begin{array}{c}\text { Agua Subt. } \\
\text { (ug/L) }\end{array} \\
\end{array}$} & \multirow{2}{*}{$\begin{array}{l}\text { D.R.F. } \\
\text { Agua Subt. } \\
\text { (ug/L) }\end{array}$} & \multirow{2}{*}{$\begin{array}{l}\text { PRGs } \\
\text { Agua Subt. } \\
\text { (ug/L) }\end{array}$} & \multirow{2}{*}{\begin{tabular}{|c|} 
MW 22 \\
C. Inicial
\end{tabular}} & \multirow{2}{*}{ MW 22} & MW 22 & \multirow{2}{*}{ MW 22} & \multirow{2}{*}{$\frac{\text { MW } 22}{11^{\circ} \text { mês }}$} & \multirow{2}{*}{\begin{tabular}{|c|} 
MW 14 \\
C. Inicial
\end{tabular}} & \multirow{2}{*}{$\begin{array}{l}\text { MW } 14 \\
1^{\circ} \text { mês }\end{array}$} & \multirow{2}{*}{$\begin{array}{l}\text { MW } 14 \\
3^{\circ} \text { mês } \\
\end{array}$} & \multirow{2}{*}{$\begin{array}{l}\text { MW } 14 \\
6^{\circ} \text { mês } \\
\end{array}$} & \multirow{3}{*}{\begin{tabular}{c|}
\multicolumn{1}{c|}{ MW 14} \\
$11^{\circ}$ mês \\
(mai-08)
\end{tabular}} & \multirow{3}{*}{\begin{tabular}{|c|} 
RW-04 \\
C. Inicial \\
(mar-07) \\
\end{tabular}} & \multirow{3}{*}{\begin{tabular}{c|} 
RW-04 \\
$1^{\circ}$ mês \\
(jul-07)
\end{tabular}} & \multirow{3}{*}{$\begin{array}{l}\text { RW-04 } \\
\frac{3^{\circ} \text { mês }}{(\text { set-07) }}\end{array}$} & \multirow{3}{*}{\begin{tabular}{l|} 
RW-04 \\
$6^{\circ}$ mês \\
(dez-07)
\end{tabular}} & \multirow{2}{*}{\begin{tabular}{|c|} 
RW-04 \\
$11^{\circ}$ mês \\
\end{tabular}} \\
\hline & & & & & & & $3^{\circ}$ mês & & & & & & & & & & & & \\
\hline & & & & & (mar-07) & (jul-07) & $\begin{array}{l}\text { (set-07) } \\
\end{array}$ & (dez-07) & (mai-08) & (mar-07) & (jul-07) & (set-07) & (dez-07) & & & & & & (mai-08) \\
\hline Benzeno & 5 & 5 & 30 & $\begin{array}{l}3,50 \mathrm{E}-01 \\
\end{array}$ & $<<1$ & $<1$ & $<1$ & $<1$ & $<1$ & 1,5 & $<1$ & $<1$ & 1,5 & $<1$ & 1,3 & $<1$ & $<<1$ & & $\begin{array}{ll}<1 \\
\end{array}$ \\
\hline Bromodiclorometano & & 100 & - & $1,80 \mathrm{E}-01$ & $<1$ & $<1$ & $<1$ & $<1$ & $<1$ & $<1$ & $<1$ & $<1$ & $<1$ & $<1$ & $<1$ & $<1$ & $<1$ & $<1$ & $<1$ \\
\hline Bromofórmio & - & & - & $8,50 \mathrm{E}+00$ & $<1$ & $<1$ & $<1$ & $<1$ & $<1$ & $<1$ & $<1$ & $<1$ & $<1$ & $<1$ & $<1$ & $<1$ & $<1$ & $<1$ & $<1$ \\
\hline Bromometano & - & - & - & $8,70 \mathrm{E}+00$ & $<5$ & $<5$ & $<5$ & $<5$ & $<5$ & $<5$ & $<5$ & $<5$ & $<5$ & $<5$ & $<5$ & $<5$ & $<5$ & $<5$ & $<5$ \\
\hline Dissulfeto de carbono & - & - & - & $1,00 E+03$ & $<1$ & $<1$ & $<1$ & $<1$ & $<1$ & $<1$ & $<1$ & $<1$ & $<1$ & 1,8 & $<1$ & 6,6 & 7,3 & 54 & 18 \\
\hline Tetracloreto de carbono & 2 & 2 & - & $1,70 \mathrm{E}-01$ & $<1$ & $<1$ & $<1$ & $<1$ & $<1$ & $<1$ & $<1$ & $<1$ & $<1$ & $<1$ & $<1$ & $<1$ & $<1$ & $<1$ & $<1$ \\
\hline $\begin{array}{l}\text { Clorobenzeno } \\
\end{array}$ & 700 & - & 180 & $1,10 \mathrm{E}+02$ & $<1$ & $<1$ & $<1$ & $<1$ & $<1$ & $<1$ & $<1$ & $<1$ & $<1$ & $<1$ & $<1$ & $<1$ & $<1$ & $<1$ & $<1$ \\
\hline Cloroetano & & & & $4,60 E+00$ & $<1$ & $<1$ & $<1$ & $<1$ & $<1$ & 8,9 & 2,4 & 2,4 & 6,2 & $<1$ & 8 & $<1$ & $<1$ & $<1$ & $<1$ \\
\hline Clorofórmio & 200 & 100 & 400 & $1,70 \mathrm{E}-01$ & 3,5 & $<1$ & 1,1 & 3,1 & 2 & 6 & 4,9 & 3,3 & 5,9 & $<1$ & 4,6 & 2,9 & 1,7 & 6,1 & 1,8 \\
\hline Clorometano & & & & $1,60 E+02$ & $<1$ & $<1$ & $<1$ & $<10$ & $<10$ & $<1$ & $<1$ & $<1$ & $<10$ & $<10$ & $<1$ & $<1$ & $<1$ & $<10$ & $<10$ \\
\hline Dibromoclorometano & & 100 & & $1,30 \mathrm{E}-01$ & $<1$ & $<1$ & $<1$ & $<1$ & $<1$ & $<1$ & $<1$ & $<1$ & $<1$ & $<1$ & $<1$ & $<1$ & $<1$ & $<1$ & $<1$ \\
\hline 1,1-Dicloroetano & 280 & & 900 & $8,10 \mathrm{E}+02$ & 915 & 872 & 115 & 676 & 501 & 2155 & 1660 & 1075 & 3110 & 1490 & 2390 & 655 & 612 & 2340 & 1250 \\
\hline 1,2-Dicloroetano & 10 & 10 & 400 & $1,20 \mathrm{E}-01$ & $<1$ & $<1$ & $<1$ & $<1$ & $<1$ & 4,5 & 2,2 & 2 & 4,9 & 2,4 & 5,5 & $<1$ & $<1$ & 2 & 2,1 \\
\hline 1,1-Dicloroeteno & 30 & 30 & 10 & $3,40 \mathrm{E}+02$ & 812 & 725 & 53 & 836 & 441 & 1115 & 670 & 430 & 1540 & 700 & 1145 & 420 & 218 & 1090 & 238 \\
\hline cis-1,2-Dicloroeteno & $50^{* *}$ & & 20 & $6,10 E+01$ & 20 & 13 & 2,3 & 17 & 12 & 30 & 14 & 12 & 43 & 15 & 28 & 8,1 & 9,7 & 34 & 17 \\
\hline trans-1,2-Dicloroeteno & $50^{* *}$ & - & 20 & $1,20 \mathrm{E}+02$ & 7 & 4,5 & $<1$ & 5,8 & 3,7 & 8,6 & 3,9 & 3,1 & 13 & 4 & 9,4 & 2,9 & 1,7 & 9,3 & 3 \\
\hline 1,2-Dicloropropano & - & - & 80 & $1,60 \mathrm{E}-01$ & $<1$ & $<1$ & $<1$ & $<1$ & $<1$ & $<1$ & $<1$ & $<1$ & $<1$ & $<1$ & $<1$ & $<1$ & $<1$ & $<1$ & $<1$ \\
\hline 1,3-Dicloropropano & - & - & - & $1,20 \mathrm{E}+02$ & $<5$ & $<5$ & $<5$ & $<5$ & $<1$ & $<5$ & $<5$ & $<5$ & $<5$ & $<1$ & $<5$ & $<5$ & $<5$ & $<5$ & $<5$ \\
\hline 1,1-Dicloropropeno & - & - & - & - & $<1$ & $<1$ & $<1$ & $<1$ & $<1$ & $<1$ & $<1$ & $<1$ & $<1$ & $<1$ & $<1$ & $<1$ & $<1$ & $<1$ & $<1$ \\
\hline cis-1,3-Dicloropropeno & - & - & - & & $<1$ & $<1$ & $<1$ & $<1$ & 12 & $<1$ & $<1$ & $<1$ & $<1$ & $<1$ & $<1$ & $<1$ & $<1$ & $<1$ & $<1$ \\
\hline Etilbe & 300 & 200 & 150 & $1,30 E+03$ & $<1$ & $<1$ & $<1$ & $<1$ & $<1$ & $<1$ & $<1$ & $<1$ & $<1$ & $<1$ & $<1$ & $<1$ & $<1$ & $<1$ & $<1$ \\
\hline Diclorometano & 20 & 20 & 1000 & & $<1$ & $<1$ & $<1$ & $<1$ & $<1$ & 1 & $<1$ & $<1$ & $<1$ & $<1$ & 3,4 & $<1$ & $<1$ & $<1$ & $<1$ \\
\hline 4-Metil-2-pentanona & & & & 2,001 & $<5$ & $<5$ & $<5$ & $<5$ & $<5$ & $<5$ & $<5$ & $<5$ & $<5$ & $<5$ & $<5$ & $<5$ & $<5$ & $<5$ & $<5$ \\
\hline Estireno & 20 & 20 & 300 & 1,600 & $<1$ & $<1$ & $<1$ & $<1$ & $<1$ & $<1$ & $<1$ & $<1$ & $<1$ & $<1$ & $<1$ & $<1$ & $<1$ & $<1$ & $<1$ \\
\hline 1,1,2,2-Tetracloroetano & & & & $5,50 \mathrm{E}-02$ & $<1$ & $<1$ & $<1$ & $<1$ & $<1$ & $<1$ & $<1$ & $<1$ & $<1$ & $<1$ & $<1$ & $<1$ & $<1$ & $<1$ & $<1$ \\
\hline Tetracloroeteno & $\frac{40}{700}$ & $\frac{40}{170}-x-1$ & 40 & $1,00 \mathrm{E}-01$ & 18 & 6,2 & $<1$ & 12 & 7,6 & 12 & 9,2 & 4,9 & 17 & 7 & 17 & 5,3 & 2,6 & 13 & 2,7 \\
\hline Tolueno & 700 & 170 & 1000 & $7,20 E+02$ & $<1$ & $<1$ & $<1$ & $<1$ & $<1$ & $<1$ & $<1$ & $<1$ & $<1$ & $<1$ & $<1$ & $<1$ & $<1$ & $<1$ & $<1$ \\
\hline 1,1,1-Tricloroetano & 280 & - & 300 & $3,20 E+03$ & 1,4 & 1,2 & $<1$ & $<1$ & $<1$ & $<1$ & $<1$ & $<1$ & $<1$ & $<1$ & $<1$ & $<1$ & $<1$ & $<1$ & $<1$ \\
\hline 1,1,2-Tricloroetano & - & - & 130 & $2,00 \mathrm{E}-01$ & 2,7 & 3,2 & $<1$ & 3,2 & 3 & 14 & 8,9 & 8,9 & 19 & 7,6 & 16 & $<1$ & $<1$ & 9,2 & 8,9 \\
\hline Tricloroeteno & 70 & 70 & 500 & $\begin{array}{l}2,80 \mathrm{E}-02 \\
, 00502\end{array}$ & 63 & 45 & 6,4 & 60 & 46 & 20 & 12 & 9,1 & 35 & 11 & 25 & 13 & 5,1 & 32 & 8,9 \\
\hline Cloreto de vinila & 5 & 5 & 5 & $2,00 \mathrm{E}-02$ & 1,1 & $<1$ & $<1$ & 1,3 & $<1$ & 2,2 & 1,1 & $<1$ & 3,4 & 1,3 & 5,1 & 3 & 1,2 & 2,3 & 13 \\
\hline Xilenos (total) & 500 & 300 & 70 & $2,10 \mathrm{E}+02$ & $<3$ & $\begin{array}{l}<3 \\
1701 \\
\end{array}$ & $<3$ & $\frac{<3}{161+4}$ & $<3$ & $<3$ & $<3$ & $<3$ & 3,4 & $<3$ & $<3$ & $<3$ & $<3$ & 3,4 & $<3$ \\
\hline VoCs Totais & & & & & 1843,7 & 1670,1 & 177,8 & 1614,4 & 1028,3 & 33378,70 & 2388,60 & 1550,70 & 4802,30 & 2240,10 & 3658,30 & 1116,80 & 859,30 & 3596,30 & 1563,40 \\
\hline
\end{tabular}

Portaria n⿳ 518104 : Padrão de Potabilidade estabelecido pelo Minitério da Saúde

CETESB: Companhia de Tecnologia de Sa

PRGs: Preliminary Remediation Goals (Region Ix) 
Anexo 2A-3 - Resultados das análises de VOCs do (conjunto RW-04)

\begin{tabular}{|c|c|c|c|c|c|c|c|c|c|c|c|c|c|c|c|c|c|c|c|}
\hline \multirow{3}{*}{ Compostos } & \multirow{2}{*}{$\begin{array}{c}\text { CETESB } \\
\begin{array}{c}\text { Agua Subt. } \\
\text { (ug/L) }\end{array} \\
\end{array}$} & \multirow{2}{*}{\begin{tabular}{|c|} 
Port.no $518 / 04$ \\
$\begin{array}{c}\text { Agua Subt. } \\
\text { (ug/L) }\end{array}$ \\
\end{tabular}} & \multirow{2}{*}{$\begin{array}{c}\text { D.R.F. } \\
\begin{array}{c}\text { Agua Subt. } \\
\text { (ug/L) }\end{array} \\
\end{array}$} & \multirow{2}{*}{$\begin{array}{c}\text { PRGs } \\
\begin{array}{c}\text { Agua Subt. } \\
\text { (ug/L) }\end{array} \\
\end{array}$} & MW 304 & MW 304 & \multirow{2}{*}{ MW 304} & \multirow{2}{*}{ MW 304} & \multirow{2}{*}{\begin{tabular}{|l} 
MW 304 \\
\end{tabular}} & \multirow{2}{*}{ MW 305} & \multirow{2}{*}{$\begin{array}{l}\text { MW } 305 \\
1^{\circ} \text { mês }\end{array}$} & \multirow{2}{*}{$\frac{\text { MW } 305}{3^{\circ} \text { mês }}$} & \multirow{2}{*}{\begin{tabular}{|c|} 
MW 305 \\
$6^{\circ}$ mês
\end{tabular}} & \multirow{2}{*}{$\frac{\text { MW } 305}{11^{\circ} \mathrm{mês}}$} & \multirow{2}{*}{\begin{tabular}{|l|} 
MW 306 \\
C. Inicial \\
\end{tabular}} & \multirow{2}{*}{$\begin{array}{l}\text { MW } 306 \\
1^{\circ} \text { mês }\end{array}$} & \multirow{2}{*}{\begin{tabular}{|c|} 
MW 306 \\
$3^{\circ}$ mês
\end{tabular}} & \multirow{2}{*}{$\begin{array}{l}\text { MW } 306 \\
6^{\circ} \text { mês }\end{array}$} & \multirow{2}{*}{\begin{tabular}{|c|} 
MW 306 \\
$11^{\circ}$ mês \\
\end{tabular}} \\
\hline & & & & & C. Inicial & $1^{\circ}$ mês & & & & & & & & & & & & & \\
\hline & Intervenção & $\begin{array}{l}\text { Potabilidade } \\
\end{array}$ & Intervenção & "Tap Water" & (mar-07) & $\begin{array}{l}\text { (jul-07) } \\
\end{array}$ & $\begin{array}{l}\text { (set-07) } \\
\end{array}$ & $\begin{array}{l}\text { (dez-07) } \\
\end{array}$ & (mai-08) & (mar-07) & (jul-07) & (set-07) & (dez-07) & (mai-08) & $($ mar-07) & (jul-07) & (set-07) & (dez-07) & $\begin{array}{l}\text { (mai-08) } \\
\end{array}$ \\
\hline Benzeno & 5 & 5 & 30 & $\begin{array}{l}3,50 \mathrm{E}-01 \\
\end{array}$ & $\overline{11,4}$ & 1,8 & $<1$ & $1,1,7$ & 1,3 & $\overline{1,4}$ & 1,8 & $<<1$ & $\overline{1,1}$ & $1,1,6$ & $<<1$ & 1,6 & $<<1$ & $\overline{1,5}$ & $\overline{l<1}$ \\
\hline Bromodiclorometano & & 100 & & $1,80 \mathrm{E}-01$ & $<1$ & $<1$ & $<1$ & $<1$ & $<1$ & $<1$ & $<1$ & $<1$ & $<1$ & $<1$ & $<1$ & $<1$ & $<1$ & $<1$ & $<1$ \\
\hline Bromofórmio & - & & - & $8,50 \mathrm{E}+00$ & $<1$ & $<1$ & $<1$ & $<1$ & $<1$ & $<1$ & $<1$ & $<1$ & $<1$ & $<1$ & $<1$ & $<1$ & $<1$ & $<1$ & $<1$ \\
\hline Bromometano & - & - & - & $8,70 \mathrm{E}+00$ & $<5$ & $<5$ & $<5$ & $<5$ & $<5$ & $<5$ & $<5$ & $<5$ & $<1$ & $<5$ & $<5$ & $<5$ & $<5$ & $<5$ & $<5$ \\
\hline Dissulfeto de carbono & - & - & - & $1,00 \mathrm{E}+03$ & $<1$ & $<1$ & $<1$ & $<1$ & 1,4 & $<1$ & $<1$ & $<1$ & $<1$ & $<1$ & $<1$ & $<1$ & $<1$ & 1,5 & $<1$ \\
\hline Tetracloreto de carbono & 2 & 2 & - & $1,70 \mathrm{E}-01$ & $<1$ & $<1$ & $<1$ & $<1$ & $<1$ & $<1$ & $<1$ & $<1$ & $<1$ & $<1$ & $<1$ & $<1$ & $<1$ & $<1$ & $<1$ \\
\hline Clorobenzeno & 700 & - & 180 & $1,10 \mathrm{E}+02$ & $<1$ & $<1$ & $<1$ & $<1$ & $<1$ & $<1$ & $<1$ & $<1$ & $<1$ & $<1$ & $<1$ & $<1$ & $<1$ & $<1$ & $<1$ \\
\hline Cloroetano & - & - & & $4,60 E+00$ & 1,8 & 2,6 & 4,7 & 26 & 8,5 & 3,4 & 2 & 32 & 23 & 8,3 & 15 & 6,1 & $<1$ & 1,9 & $<1$ \\
\hline Clorofórmio & 200 & 100 & 400 & $1,70 \mathrm{E}-01$ & 8,6 & 8,6 & 4,8 & 9,9 & 6,4 & 8,1 & 7,7 & 3,8 & 7,4 & 8,8 & 5,7 & $<1$ & 1,7 & 5,1 & $<1$ \\
\hline Clorometano & - & & & $1,60 E+02$ & $<1$ & $<1$ & $<1$ & $<10$ & $<10$ & $<1$ & $<1$ & $<1$ & $<10$ & $<10$ & $<1$ & $<1$ & $<1$ & $<10$ & $<10$ \\
\hline Dibromoclorometano & & 100 & & $1,30 \mathrm{E}-01$ & $<1$ & $<1$ & $<1$ & $<1$ & $<1$ & $<1$ & $<1$ & $<1$ & $<1$ & $<1$ & $<1$ & $<1$ & $<1$ & $<1$ & $<1$ \\
\hline 1,1-Dicloroetano & 280 & & 900 & $8,10 \mathrm{E}+02$ & 2575 & 3600 & 1390 & 2980 & 2390 & 2670 & 5000 & 1910 & 2440 & 3850 & 1630 & 2790 & 1035 & 3280 & 2960 \\
\hline 1,2-Dicloroetano & 10 & 10 & 400 & $1,20 \mathrm{E}-01$ & 4.7 & 6,6 & $<1$ & 6,3 & 4,5 & 4 & 5,9 & 3,1 & 5,7 & 5,4 & 2,5 & 5,1 & $<1$ & 5,5 & 5.9 \\
\hline 1,1-Dicloroeteno & 30 & 30 & 10 & $3,40 \mathrm{E}+02$ & 1460 & 2000 & 540 & 1440 & 1040 & 2110 & 2600 & 620 & 888 & 2240 & 1515 & 2250 & 370 & 1640 & 2160 \\
\hline cis-1,2-Dicloroeteno & $50^{* *}$ & & 20 & $6,10 \mathrm{E}+01$ & 38 & 49 & 24 & 60 & 34 & 46 & 47 & 21 & 45 & 47 & 37 & 44 & 16 & 64 & 73 \\
\hline trans-1,2-Dicloroeteno & $50^{* *}$ & 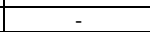 & 20 & $1,20 \mathrm{E}+02$ & 11 & 16 & 4,4 & 17 & 8,3 & 15 & 17 & 5,5 & 12 & 15 & 13 & 16 & 3,3 & 16 & 14 \\
\hline 1,2-Dicloropropano & - & - & 80 & $1,60 \mathrm{E}-01$ & $<1$ & $<1$ & $<1$ & $<1$ & $<1$ & $<1$ & $<1$ & $<1$ & $<1$ & $<1$ & $<1$ & $<1$ & $<1$ & $<1$ & $<1$ \\
\hline 1,3-Dicloropropano & - & - & & $1,20 \mathrm{E}+02$ & $<5$ & $<5$ & $<5$ & $<5$ & $<5$ & $<5$ & $<5$ & $<5$ & $<5$ & $<1$ & $<5$ & $<5$ & $<5$ & $<5$ & $<5$ \\
\hline 1,1-Dicloropropeno & - & - & - & & $<1$ & $<1$ & $<1$ & $<1$ & $<1$ & $<1$ & $<1$ & $<1$ & $<1$ & $<1$ & $<1$ & $<1$ & $<1$ & $<1$ & $<1$ \\
\hline cis-1,3-Dicloropropeno & - & - & - & & $<1$ & $<1$ & $<1$ & $<1$ & $<1$ & $<1$ & $<1$ & $<1$ & $<1$ & $<1$ & $<1$ & $<1$ & $<1$ & $<1$ & $<1$ \\
\hline Etilbenzeno & 300 & 200 & 150 & $1,30 \mathrm{E}+03$ & $<1$ & $<1$ & $<1$ & $<1$ & $<1$ & $<1$ & $<1$ & $<1$ & $<1$ & $<1$ & $<1$ & $<1$ & $<1$ & $<1$ & $<1$ \\
\hline Diclorometano & 20 & 20 & 1000 & $4,30 \mathrm{E}+00$ & $<1$ & $<1$ & $<1$ & $<1$ & $<1$ & 2,2 & $<1$ & $<1$ & $<1$ & $<1$ & $<1$ & $<1$ & $<1$ & $<1$ & $<1$ \\
\hline 4-Metil-2-pentanona & & & & $2,00 \mathrm{E}+03$ & $<5$ & $<5$ & $<5$ & $<5$ & $<5$ & $<5$ & $<5$ & $<5$ & $<5$ & $<5$ & $<5$ & $<5$ & $<5$ & $<5$ & $<5$ \\
\hline Estireno & 20 & 20 & 300 & $1,60 \mathrm{E}+03$ & $<1$ & $<1$ & $<1$ & $<1$ & $<1$ & $<1$ & $<1$ & $<1$ & $<1$ & $<1$ & $<1$ & $<1$ & $<1$ & $<1$ & $<1$ \\
\hline 1,1,2,2-Tetracloroetano & & & & $5,50 \mathrm{E}-02$ & $<1$ & $<1$ & $<1$ & $<1$ & $<1$ & $<1$ & $<1$ & $<1$ & $<1$ & $<1$ & $<1$ & $<1$ & $<1$ & $<1$ & $<1$ \\
\hline Tetracloroeteno & 40 & 40 & 40 & $1,00 \mathrm{E}-01$ & 7,4 & 19 & 5 & 16 & 7,9 & 6,2 & 6,7 & 4,1 & 10 & 13 & 4,3 & 8,6 & 1,6 & 12 & 5,6 \\
\hline Tolueno & 700 & 170 & 1000 & $7,20 \mathrm{E}+02$ & $<1$ & $<1$ & $<1$ & $<1$ & $<1$ & $<1$ & $<1$ & $<1$ & $<1$ & $<1$ & $<1$ & $<1$ & $<1$ & $<1$ & $<1$ \\
\hline 1,1,1-Tricloroetano & 280 & & 300 & $3,20 \mathrm{E}+03$ & $<1$ & $<1$ & $<1$ & $<1$ & $<1$ & $<1$ & $<1$ & $<1$ & $<1$ & $<1$ & $<1$ & $<1$ & $<1$ & $<1$ & $<1$ \\
\hline 1,1,2-Tricloroetano & - & - & 130 & $2,00 E-01$ & 18 & 26 & 18 & 26 & 22 & 17 & 27 & 14 & 27 & 25 & 7,8 & 12 & 7,6 & 21 & 12 \\
\hline Tricloroeteno & 70 & 70 & 500 & 2,80 & 41 & 42 & 13 & 49 & 27 & 59 & 38 & 16 & 37 & 41 & 51 & 82 & 15 & 55 & 39 \\
\hline Cloreto de vinila & 5 & 5 & 5 & $2,00 \mathrm{E}-02$ & 3 & 4,7 & 1,4 & 50 & 19 & 2,8 & 4,6 & 2,1 & 14 & 8,7 & 4,8 & 5,7 & $<1$ & 11 & 8,6 \\
\hline Xilenos (total) & 500 & 300 & 70 & $2,10 \mathrm{E}+02$ & $<3$ & 3,2 & $<3$ & 3,8 & $<3$ & $<3$ & $<3$ & $<3$ & $<3$ & $<3$ & $<3$ & $<3$ & $<3$ & $<3$ & $<3$ \\
\hline VOCs Totais & & & & & 4169,90 & 5779,50 & 2005,30 & $4 \quad 4685,70$ & 3570,30 & 4945,10 & $\begin{array}{l}7757,70 \\
\end{array}$ & 2631,60 & 3510,20 & 6263,80 & 3286,10 & 5221,10 & 1450,20 & 5114,50 & 5278,10 \\
\hline
\end{tabular}

Portaria n ${ }^{\circ} 518104$ : Padrão de Potabilidade estabelecido pelo Minitério da Saúde

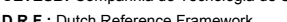

PRGs: Preliminary Remediation Goals (Region Ix) 
Anexo 2A-4 - Resultados das análises de VOCs para controle de qualidade

\begin{tabular}{|c|c|c|c|c|c|c|c|c|c|c|c|c|c|c|c|c|c|c|c|}
\hline \multirow{3}{*}{ Compostos } & \multirow{3}{*}{ 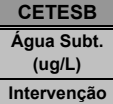 } & \multirow{2}{*}{\begin{tabular}{|c|} 
Port.n $0^{\circ} 518 / 04$ \\
Agua Subt. \\
(ug/L) \\
\end{tabular}} & \multirow{2}{*}{$\begin{array}{c}\text { D.R.F. } \\
\begin{array}{c}\text { Aggaa Subt. } \\
\text { (ug/L) }\end{array}\end{array}$} & \multirow{3}{*}{ 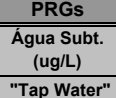 } & \begin{tabular}{|c|c|} 
DPC \\
(RW-04)
\end{tabular} & BCO & BCE & \begin{tabular}{|c|} 
DPC-01 \\
(MW-14)
\end{tabular} & $\mathrm{BCO}$ & BCE & \begin{tabular}{|c|c|} 
DPC \\
(MW-304)
\end{tabular} & $\mathrm{BCO}$ & BCE & \begin{tabular}{|c|} 
DPC-03 \\
$(\mathrm{MW}-306)$
\end{tabular} & $\mathrm{BCO}$ & BCE & \begin{tabular}{|c|c|} 
DPC \\
(MW-13)
\end{tabular} & BCO & BCE \\
\hline & & & & & \multicolumn{3}{|c|}{ 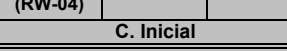 } & \multirow{2}{*}{\multicolumn{3}{|c|}{$\begin{array}{l}1^{\circ} \text { mês } \\
\text { (jul-07) }\end{array}$}} & \multirow{2}{*}{\multicolumn{3}{|c|}{$\begin{array}{l}3^{\circ} \text { mês } \\
(\text { (set-07) }\end{array}$}} & \multirow{2}{*}{\multicolumn{3}{|c|}{$\begin{array}{l}6^{\circ} \text { mês } \\
\text { (dez-07) }\end{array}$}} & \multirow{2}{*}{\multicolumn{3}{|c|}{ (mai-08) }} \\
\hline & & & Intervenção & & & (mar-07) & & & & & & & & & & & & & \\
\hline Benzeno & 5 & \begin{tabular}{c|}
5 \\
\end{tabular} & 30 & $\begin{array}{l}3,50 \mathrm{E}-01 \\
\end{array}$ & 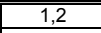 & $2<1$ & $<<1$ & $2<1$ & $<<1$ & $2<1$ & $\begin{array}{ll}<1 \\
\end{array}$ & $<<1$ & $2<1$ & 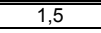 & $2<1$ & $\begin{array}{ll}<1 \\
\end{array}$ & 41 & & $\begin{array}{ll}<1 \\
\end{array}$ \\
\hline Bromodiclorometano & - & 100 & - & $1,80 \mathrm{E}-01$ & $<1$ & $<1$ & $<1$ & $<1$ & $<1$ & $<1$ & $<1$ & $<1$ & $<<1$ & $<1$ & 1,8 & 2,2 & $<1$ & $<1$ & $<1$ \\
\hline Bromofórmio & - & & & $8,50 \mathrm{E}+00$ & $<1$ & $<1$ & $<1$ & $<1$ & $<1$ & $<<1$ & $<1$ & $<1$ & $<1$ & $<1$ & $<1$ & $<1$ & $<1$ & $<1$ & $<1$ \\
\hline Bromometano & - & - & - & $8,70 E+00$ & $<5$ & $<5$ & $<5$ & $<5$ & $<5$ & $<5$ & $<5$ & $<5$ & $<5$ & $<5$ & $<5$ & $<5$ & $<5$ & $<5$ & $<5$ \\
\hline Dissulfeto de carbono & - & - & - & $1,00 E+03$ & $<1$ & $<1$ & $<1$ & $<1$ & $<1$ & $<1$ & $<1$ & $<1$ & $<1$ & 2,1 & $<1$ & $<1$ & $<1$ & $<1$ & $<1$ \\
\hline Tetracloreto de carbono & 2 & 2 & - & $1,70 \mathrm{E}-01$ & $<1$ & $<1$ & $<1$ & $<1$ & $<1$ & $<1$ & $<1$ & $<1$ & $<1$ & $<1$ & $<1$ & $<1$ & $<1$ & $<1$ & $<1$ \\
\hline Clorobenzeno & 700 & - & 180 & $1,10 \mathrm{E}+02$ & $<1$ & $<1$ & $<1$ & $<1$ & $<1$ & $<1$ & $<1$ & $<1$ & $<1$ & $<1$ & $<1$ & $<1$ & $<1$ & $<1$ & $<1$ \\
\hline Cloroetano & & & & $4,60 E+00$ & 7,7 & $<1$ & $<1$ & 2,3 & $<1$ & $<1$ & 4,1 & $<1$ & $<1$ & 1,8 & $<1$ & $<1$ & 47 & $<1$ & $<1$ \\
\hline Clorofórmio & 200 & 100 & 400 & $1,70 \mathrm{E}-01$ & 4,5 & 6,7 & 18 & 3,4 & $<1$ & $<1$ & 4,9 & 5,3 & 5,7 & 4,8 & 21 & 26 & 1,1 & 12 & 12 \\
\hline Clorometano & & & & $1,60 E+02$ & $<1$ & $<1$ & $<1$ & $<1$ & $<1$ & $<1$ & $<1$ & $<1$ & $<1$ & $<10$ & $<10$ & $<10$ & $<10$ & $<10$ & $<10$ \\
\hline Dibromoclorometano & & 100 & & $1,30 \mathrm{E}-01$ & $<1$ & $<1$ & $<1$ & $<1$ & $<1$ & $<1$ & $<1$ & $<1$ & $<1$ & $<1$ & $<1$ & $<1$ & $<1$ & $<1$ & $<1$ \\
\hline 1,1-Dicloroetano & 280 & & 900 & $8,10 E+02$ & 2285 & $<1$ & $<1$ & 1480 & $<1$ & $<1$ & 1560 & $<1$ & $<1$ & 2620 & $<1$ & 6,7 & 503 & $<1$ & $<1$ \\
\hline 1,2-Dicloroetano & 10 & 10 & 400 & $1,20 \mathrm{E}-01$ & 4,8 & $<1$ & $<1$ & 1,7 & $<1$ & $<1$ & 3,5 & $<1$ & $<1$ & 5,4 & $<1$ & $<1$ & 5,1 & $<1$ & $<1$ \\
\hline 1,1-Dicloroeteno & 30 & 30 & 10 & $3,40 E+02$ & 1185 & $<1$ & $<1$ & 500 & $<1$ & $<1$ & 586 & $<1$ & $<1$ & 1200 & $<1$ & 8,6 & 99 & $<1$ & $<1$ \\
\hline cis-1,2-Dicloroeteno & $50^{* *}$ & - & 20 & $6,10 E+01$ & 27 & $<1$ & $<1$ & 13 & $<1$ & $<1$ & 17 & $<1$ & $<1$ & 60 & $<1$ & $<1$ & 23 & $<1$ & $<1$ \\
\hline trans-1,2-Dicloroeteno & $50^{* *}$ & - & 20 & $1,20 E+02$ & 8,3 & $<1$ & $<1$ & 3,7 & $<1$ & $<1$ & 3,7 & $<1$ & $<1$ & 15 & $<1$ & $<1$ & 2,4 & $<1$ & $<1$ \\
\hline 1,2-Dicloropropano & - & - & 80 & $1,60 \mathrm{E}-01$ & $<1$ & $<1$ & $<1$ & $<1$ & $<1$ & $<1$ & $<1$ & $<1$ & $<1$ & $<1$ & $<1$ & $<1$ & $<1$ & $<1$ & $<1$ \\
\hline 1,3-Dicloropropano & - & - & - & $1,20 \mathrm{E}+02$ & $<5$ & $<5$ & $<5$ & $<5$ & $<5$ & $<5$ & $<5$ & $<5$ & $<5$ & $<5$ & $<5$ & $<5$ & $<5$ & $<5$ & $<5$ \\
\hline 1,1-Dicloropropeno & - & - & & & $<1$ & $<1$ & $<1$ & $<1$ & $<1$ & $<1$ & $<1$ & $<1$ & $<1$ & $<1$ & $<1$ & $<1$ & $<1$ & $<1$ & $<1$ \\
\hline cis-1,3-Dicloropropeno & & & & & $<1$ & $<1$ & $<1$ & $<1$ & $<1$ & $<1$ & $<1$ & $<1$ & $<1$ & $<1$ & $<1$ & $\leq 1$ & $<1$ & $<1$ & $<1$ \\
\hline Etilbenz & 300 & 200 & 150 & $1,30 \mathrm{E}+03$ & $<1$ & $<1$ & $<1$ & $<1$ & $<1$ & $<1$ & $<1$ & $<1$ & $<1$ & $<1$ & $<1$ & $<1$ & 1,2 & $<1$ & $<1$ \\
\hline Diclorometano & 20 & 20 & 1000 & $4,30 E+00$ & 2,5 & $<1$ & $<1$ & $<1$ & $<1$ & $<1$ & $<1$ & $<1$ & $<1$ & $<1$ & $<1$ & $<1$ & $<1$ & $<1$ & $<1$ \\
\hline 4-Metil-2-pentanona & & & 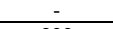 & $2,00 E+03$ & $<5$ & $<5$ & $<5$ & $<5$ & $<5$ & $<5$ & $<5$ & $<5$ & $<5$ & $<5$ & $<5$ & $<5$ & $<5$ & $<5$ & $<5$ \\
\hline Estireno & 20 & 20 & 300 & $1,60 E+03$ & $<1$ & $<1$ & $<1$ & $<1$ & $<1$ & $<1$ & $<1$ & $<1$ & $<1$ & $<1$ & $<1$ & $<1$ & $<1$ & $<1$ & $<1$ \\
\hline 1,1,2,2-Tetracloroetano & & & & $5,50 \mathrm{E}-02$ & $<1$ & $<1$ & $<1$ & $<1$ & $<1$ & $<1$ & $<1$ & $<1$ & $<1$ & $<1$ & $<1$ & 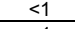 & $<1$ & $<1$ & $<1$ \\
\hline Tetracloroeteno & 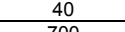 & 40 & $\frac{40}{1000}$ & $1,00 \mathrm{E}-01$ & 13 & $<1$ & $<1$ & 8,3 & $<1$ & $<1$ & 3,3 & $<1$ & $<1$ & 11 & $<1$ & $<1$ & 17 & $<1$ & $<1$ \\
\hline $\begin{array}{c}\text { Tolueno } \\
\text { 111-Tricloret }\end{array}$ & 700 & 170 & $\frac{1000}{300}$ & $\begin{array}{l}7,20 \mathrm{E}+02 \\
320 \mathrm{O}+03\end{array}$ & $<1$ & $<1$ & $\begin{array}{l}<1 \\
<1\end{array}$ & $<1$ & $<1$ & $<1$ & $<1$ & $<1$ & $\begin{array}{l}<1 \\
<1\end{array}$ & $<1$ & $<1$ & $\leq 1$ & $<1$ & $<1$ & $<1$ \\
\hline 1,1,1-Tricloroetano & 280 & & 300 & $3,20 E+03$ & $<1$ & $<1$ & $<1$ & $<1$ & $<1$ & $<1$ & $<1$ & $<1$ & $<1$ & $<1$ & $<1$ & $<1$ & 1,8 & $<1$ & $<1$ \\
\hline 1,1,2-Tricloroetano & & & $\frac{130}{550}$ & $2,00 \mathrm{E}-01$ & 13 & $<1$ & $<1$ & 7,5 & $<1$ & $<1$ & 13 & $<1$ & $<1$ & $\frac{22}{52}$ & $<1$ & $<1$ & 16 & $<1$ & $<1$ \\
\hline $\begin{array}{l}\text { Tricloroeteno } \\
\text { Clareto de vinila }\end{array}$ & $\frac{70}{5}$ & $\frac{70}{5}$ & $\frac{500}{5}$ & $\frac{2,80 \mathrm{E}-02}{200-02}$ & $\frac{26}{43}$ & $<1$ & $\begin{array}{l}<1 \\
<1\end{array}$ & $\frac{13}{14}$ & $\begin{array}{l}<1 \\
<1\end{array}$ & $\begin{array}{l}<1 \\
<1\end{array}$ & $\frac{12}{<1}$ & $\begin{array}{l}<1 \\
<1\end{array}$ & $\begin{array}{l}<1 \\
<1\end{array}$ & $\frac{53}{11}$ & $<1$ & $\leq 1$ & $\frac{12}{114}$ & $\leq 1$ & $<1$ \\
\hline $\begin{array}{l}\text { Cloreto de vinila } \\
\text { Xilenos (total) }\end{array}$ & $\frac{5}{500}$ & $\frac{5}{300}$ & $\frac{5}{70}$ & $\begin{array}{l}2,00 E-02 \\
2,10 E+02 \\
\end{array}$ & $\frac{4,3}{<3}$ & $\begin{array}{l}<1 \\
<3\end{array}$ & $\begin{array}{l}<1 \\
<3\end{array}$ & $\frac{1,4}{<3}$ & $\begin{array}{l}<1 \\
<3\end{array}$ & $\begin{array}{l}<1 \\
<3\end{array}$ & $\begin{array}{l}<1 \\
<3\end{array}$ & $\begin{array}{l}<1 \\
<3\end{array}$ & $\begin{array}{l}<1 \\
<3\end{array}$ & $\frac{11}{<3}$ & $\begin{array}{l}<1 \\
<3\end{array}$ & $\frac{<1}{<3}$ & $\frac{145}{2.4}$ & $\frac{<1}{<3}$ & $\begin{array}{l}<1 \\
<3\end{array}$ \\
\hline VOCs Totais & & & $\overline{\bar{E}}$ & & 3582,30 & $\begin{array}{ll}6,70 \\
\end{array}$ & 18,00 & 2034,30 & 0,00 & 0,00 & 2207,50 & 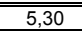 & 5,70 & 4007,60 & 222,80 & 433,50 & $\begin{array}{l}876,00 \\
\end{array}$ & 12,00 & $\overline{12,00}$ \\
\hline
\end{tabular}

Portaria n ${ }^{\circ} 518104:$ Padrão de Potabilidade estabelecido pelo Minitério da Saúde
CETESB: Companhia de Teconologia de Saneamento Ambiental CETESB: Companhia de Tecnologia de Saneamento Ambients

PRGs: Preliminary Remediation Goals (Region IX)
DPC: Amostra dupicat

BCE: Branco de Equipamento 
Anexo 2A-5 - Resultados das demais análises (conjunto RW-02)

\begin{tabular}{|c|c|c|c|c|c|c|c|c|c|c|c|c|c|c|c|c|c|c|c|}
\hline \multirow{3}{*}{ Compostos } & CETESB & Port.n ${ }^{518 / 04}$ & D.R.F. & PRGs & MW 23 & MW 23 & MW 23 & MW 23 & MW 23 & MW-13 & MW 13 & MW 13 & MW 13 & MW 13 & RW 02 & RW 02 & RW 02 & RW 02 & RW 02 \\
\hline & \begin{tabular}{|l} 
Agua Subt.(mg/L) \\
\end{tabular} & Agua Subt.(mg/L) & Agua Subt.(mg/L) & Agua Subt.(mg/L) & C. Inicial & $1^{\circ}$ mês & $3^{\circ}$ mês & $6^{\circ}$ mês & $11^{\circ}$ mês & \begin{tabular}{|l} 
C. Inicial \\
\end{tabular} & $1^{\circ}$ mês & $3^{\circ}$ mês & $6^{\circ}$ mês & $11^{\circ}$ mês & \begin{tabular}{|l|l|l} 
C. Inicial \\
\end{tabular} & $1^{\circ} \mathrm{mês}$ & $3^{\circ}$ mês & $6^{\circ}$ mês & $11^{\circ}$ mês \\
\hline & $\begin{array}{l}\text { Intervençăo } \\
0^{3}\end{array}$ & $\begin{array}{l}\text { Potabilidade } \\
{ }^{2} 2 d\end{array}$ & Intervenção & "Tap Water" & (mar-07) & (jul-07) & (set-07) & \begin{tabular}{|l|l|} 
(dez-07) \\
\end{tabular} & (mai-08) & (mar-07) & $\frac{(\text { jul-07) }}{27}$ & $\begin{array}{l}\text { (set-07) } \\
\text { s/n }\end{array}$ & 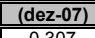 & \begin{tabular}{|l|l|} 
(mai-08) \\
\end{tabular} & (mar-07) & $\begin{array}{l}\text { (jul-07) } \\
0-021\end{array}$ & $\begin{array}{l}\text { (set-07) } \\
\end{array}$ & $\begin{array}{l}(\text { dez-07) } \\
\end{array}$ & (mai-08) \\
\hline Sulfato & & $\frac{0,3}{250}$ & & $1,10 E+01$ & $\frac{3,9}{<1}$ & $\frac{0,315}{11}$ & $\mathrm{NA}$ & \begin{tabular}{|l|}
$<0.0001$ \\
$<1$
\end{tabular} & $\frac{0,045}{<1}$ & $\frac{3,1}{<2}$ & $\frac{2,1}{57}$ & $\mathrm{NA}$ & $\frac{0,301}{26,4}$ & $\frac{24,7}{12,3}$ & $\frac{0,089}{<5}$ & $\frac{0,024}{322}$ & $\frac{\mathrm{NA}}{\mathrm{NA}}$ & $\frac{0,022}{239}$ & $\frac{0,06}{413}$ \\
\hline Alcalinidade Total & - & 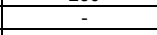 & - & - & 23 & 13 & $\mathrm{NA}$ & 17 & 9 & 11 & 90 & $\mathrm{NA}$ & 20 & $<5$ & $<5$ & 1200 & $\mathrm{NA}$ & 218 & 48 \\
\hline RedEq & & & & & 5,2 & $<1$ & 11 & 8,4 & 2,2 & 3,1 & 7,2 & 1,6 & 11 & $\frac{1.5}{1.5}$ & 2,5 & 1117 & 228 & 252 & 7,5 \\
\hline
\end{tabular}

\begin{tabular}{|c|c|c|c|c|c|c|c|c|c|c|c|c|c|c|c|c|c|c|c|}
\hline \multirow{3}{*}{ Compostos } & CETESB & Port.n $518 / 04$ & D.R.F. & PRGs & MW 301 & MW 301 & MW 301 & MW 301 & MW 301 & MW 302 & MW 302 & MW 302 & \begin{tabular}{|l|} 
MW 302 \\
\end{tabular} & MW 302 & MW 303 & MW 303 & MW 303 & MW 303 & MW 303 \\
\hline & Agua Subt.(mg/L) & Agua Subt.(mg/L) & Agua Subt.(mg/L) & Agua Subt.(mg/L) & C. Inicial & $1^{\circ}$ mês & $3^{\circ}$ mês & $6^{\circ}$ mês & $11^{\circ}$ mês & C. Inicial & $1^{\circ}$ mês & $3^{\circ}$ mês & $6^{\circ}$ mês & $11^{\circ}$ mês & | C. Inicial & $1^{\circ}$ mês & $3^{\circ}$ mês & $6^{\circ}$ mês & $11^{\circ} \mathrm{mês}$ \\
\hline & Intervencăä & Potabilidade & Intervenção & "Tap Water" & (mar-07) & (jul-07) & (set-07) & (dez-07) & (mai-08) & (mar-07) & (jul-07) & (set-07) & (dez-07) & (mai-08) & (mar-07) & (jul-07) & (set-07) & (dez-07) & (mai-08) \\
\hline Ferro Dissolvido & 0,3 & 0,3 & - & $1,10 \mathrm{E}+01$ & 0,013 & 0,013 & NA & 0,115 & & 0,023 & 5,5 & & 11,7 & 68 & 2,6 & 0,093 & $\mathrm{NA}$ & 0,182 & \\
\hline Sulfato & & 250 & - & & $<5$ & 169 & NA & 49,3 & 447 & $<5$ & 57 & NA & 256 & 511 & $<5$ & 20 & NA & 453 & 389 \\
\hline Alcalinidade Total & - & - & - & - & 125 & 96 & NA & 69 & 15 & 271 & 580 & $\mathrm{NA}$ & 5 & $<5$ & 161 & 2000 & $N A$ & 148 & 35 \\
\hline RedEq & & & & & 2 & 235 & 2,2 & 55 & & 5 & 55,3 & 11 & 213 & 1,2 & 2,9 & 390 & 55 & 129 & 1 \\
\hline
\end{tabular}

Portaria ${ }^{\circ}$ 518/04: Padrăo de Potabilidade estabelecido pelo Miniterrio da Saúde

D.R.F. Dutch Reference Framework
PRGs: Preliminary Ren

-: Nă. establimececido
NA: năo anali isado 
Anexo 2A-6 - Resultados das demais análises (conjunto RW-04)

\begin{tabular}{|c|c|c|c|c|c|c|c|c|c|c|c|c|c|c|c|c|c|c|c|}
\hline \multirow{3}{*}{ Compostos } & CETESB & Port.n ${ }^{\circ}$ 518/04 & D.R.F. & PRGs & MW 22 & MW 22 & MW 22 & MW 22 & MW 22 & MW 14 & MW 14 & MW 14 & MW 14 & MW 14 & RW-04 & RW-04 & RW-04 & RW-04 & RW 04 \\
\hline & Água Subt.(mg/L) & Água Subt.(mg/L) & \begin{tabular}{|l|l|} 
Agua Subt.(mg/L) \\
\end{tabular} & \begin{tabular}{|l|l|} 
Água Subt.(mg/L) \\
\end{tabular} & \begin{tabular}{|l|l|} 
C. Inicial \\
\end{tabular} & $1^{\circ}$ mês & $3^{\circ}$ mês & $6^{\circ}$ mês & $11^{\circ}$ mês & \begin{tabular}{|l|} 
C. Inicial \\
\end{tabular} & $1^{\circ} \mathrm{mês}$ & $3^{\circ}$ mês & $6^{\circ}$ mês & $11^{\circ}$ mês & C. Inicial & $1^{\circ} \mathrm{mês}$ & $3^{\circ}$ mês & $6^{\circ}$ mês & $11^{\circ}$ mês \\
\hline & Intervençäo & \begin{tabular}{|l|} 
Potabilidade \\
\end{tabular} & \begin{tabular}{|l|} 
Intervençăo \\
\end{tabular} & "Tap Water" & (mar-07) & (jull-07) & $\begin{array}{l}\text { (set-07) } \\
\text { set }\end{array}$ & 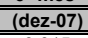 & $\begin{array}{l}\text { (mai-08) } \\
\end{array}$ & (mar-07) & $\begin{array}{l}\text { (jul-07) } \\
\end{array}$ & (set-07) & (dez-07) & (mai-08) & (mar-07) & $\begin{array}{l}(\mathrm{jul}-07) \\
\end{array}$ & (set-07) & $\begin{array}{ll}\text { (dez-07) } \\
\end{array}$ & (mai-08) \\
\hline Ferro Dissolvido & 0,3 & 0,3 & & $1,10 \mathrm{E}+01$ & 0,013 & 0,134 & $\mathrm{NA}$ & 0,015 & 0,125 & $\begin{array}{ll}1,7 \\
\end{array}$ & 0,033 & $\mathrm{NA}$ & $2,2,3$ & 12,6 & $\begin{array}{ll}0,828 \\
\end{array}$ & 0,01 & $\mathrm{NA}$ & 0,018 & 0,044 \\
\hline Sulfato & & 250 & & & $\frac{2,2,9}{2,9}$ & $\frac{13}{13}$ & $\mathrm{NA}$ & 3,9 & $\frac{3,2}{3,2}$ & $\frac{1}{<1}$ & 92 & $\mathrm{NA}$ & $\frac{115}{115}$ & 131 & $<1$ & 1624 & $\mathrm{NA}$ & 264 & 472 \\
\hline Alcalinidade Total & - & & - & - & 28 & 6,6 & $\mathrm{NA}$ & $<5$ & 10 & 11 & 45 & $\mathrm{NA}$ & $<5$ & $<5$ & 62 & 4300 & $\mathrm{NA}$ & $\frac{65}{297}$ & 143 \\
\hline RedEq & & & & & 3,1 & 2,2 & 2,6 & 2,2 & $<1$ & 3,2 & & 16 & 34 & $<1$ & 3,6 & 54 & 150 & 387 & 13 \\
\hline
\end{tabular}

\begin{tabular}{|c|c|c|c|c|c|c|c|c|c|c|c|c|c|c|c|c|c|c|c|}
\hline \multirow{3}{*}{ Compostos } & CETESB & Port.n 518/04 & D.R.F. & PRGs & MW 304 & MW 304 & MW 304 & MW 304 & MW 304 & MW 305 & MW 305 & MW 305 & MW 305 & MW 305 & MW 306 & MW 306 & MW 306 & MW 306 & MW 306 \\
\hline & Água Subt.(mg/L) & Água Subt.(mg/L) & Água Subt.(mg/L) & Água Subt.(mg/L) & \begin{tabular}{|l|l|} 
C. Inicial \\
\end{tabular} & $1^{\circ}$ mês & $3^{\circ}$ mês & $6^{\circ}$ mês & $11^{\circ}$ mês & \begin{tabular}{|l|} 
C. Inicial \\
\end{tabular} & $1^{\circ}$ mês & $3^{\circ}$ mês & $6^{\circ}$ mês & $11^{\circ}$ mês & \begin{tabular}{|l|} 
C. Inicial \\
\end{tabular} & $1^{\circ}$ mês & $3^{\circ}$ mês & $6^{\circ}$ mês & $11^{\circ}$ mês \\
\hline & Intervençāo & Potabilidade & Intervenção & "Tap Water" & $($ mar-07) & (jul-07) & (set-07) & (dez-07) & (mai-08) & \begin{tabular}{|l|} 
(mar-07) \\
\end{tabular} & (jul-07) & (set-07) & (dez-07) & (mai-08) & \begin{tabular}{|l|} 
(mar-07) \\
\end{tabular} & (jul-07) & (set-07) & (dez-07) & (mai-08) \\
\hline $\begin{array}{l}\text { Ferro Dissolvido } \\
\text { Sulfato }\end{array}$ & 0,3 & 250 & - & $1,10 \mathrm{E}+$ & $\frac{1,1}{<5}$ & $\begin{array}{l}0,035 \\
193 \\
\end{array}$ & $\mathrm{NA}$ & $\begin{array}{l}0,021 \\
18\end{array}$ & $\begin{array}{l}0,054 \\
1.9\end{array}$ & 0,027 & $\begin{array}{l}0,253 \\
181\end{array}$ & NA & $\begin{array}{l}0,051 \\
<1\end{array}$ & \begin{tabular}{l|l|}
0,044 \\
14
\end{tabular} & 0,723 & $\frac{0,563}{1441}$ & NA & 0,25 & $\begin{array}{ll}4 \\
957 \\
\end{array}$ \\
\hline Alcalinidade Total & & & & & 316 & 6,2 & NA & $\frac{1,0}{10}$ & 16 & $\frac{3}{273}$ & 33 & $N A$ & 73 & $\frac{1,4}{23}$ & $\frac{1,1}{318}$ & $\frac{1471}{42}$ & $\mathrm{NA}$ & $\frac{0,0}{79}$ & $\frac{95,7}{30}$ \\
\hline RedEq & - & - & - & - & 9 & $<1$ & 2,7 & 4,1 & 1,5 & 10 & $<2$ & 2,3 & 6,2 & 1,2 & 6,5 & 110 & 16 & 62 & $<1$ \\
\hline
\end{tabular}

Portaria ${ }^{\circ}$ 518/04: Padrăo de Potabilidade estabelecido pelo Miniterrio da Saúde

D.R.F. Dutch Reference Framework
PRGs: Preliminary Ree diation Goals (Region IX)

-: Nă. establimececido
NA: năo anali isado 
Anexo 2A-6 - Resultados das demais análises para controle de qualidade

\begin{tabular}{|c|c|c|c|c|c|c|c|c|c|c|c|c|c|c|c|c|c|c|}
\hline \multirow{3}{*}{ Compostos } & CETESB & Port.n 518/04 & D.R.F. & PRGs & $\begin{array}{c}\begin{array}{c}\text { DPC } \\
(\mathrm{RW}-04)\end{array} \\
(\mathrm{R})\end{array}$ & BCE & $\begin{array}{c}\text { DPC } \\
\text { (MW-14) }\end{array}$ & $\mathrm{BCO}$ & BCE & \begin{tabular}{|c|}
$\begin{array}{c}\text { DPC } \\
\text { (MW-304) }\end{array}$ \\
\end{tabular} & $\mathrm{BCO}$ & BCE & \begin{tabular}{|c|c} 
DPC \\
(MW-306)
\end{tabular} & BCO & BCE & $\begin{array}{c}\text { DPC } \\
\text { (MW-13) }\end{array}$ & $\mathrm{BCO}$ & BCE \\
\hline & Água Subt.(mg/L) & Água Subt.(mg/L) & Água Subt.(mg/L) & Água Subt.(mg/L) & \multirow{2}{*}{\multicolumn{2}{|c|}{\begin{tabular}{|c|} 
C. Inicial \\
(mar-07)
\end{tabular}}} & \multirow{2}{*}{\multicolumn{3}{|c|}{$\begin{array}{l}1^{\circ} \text { mês } \\
\text { (jul-07) }\end{array}$}} & \multirow{2}{*}{\multicolumn{3}{|c|}{$\begin{array}{ll}3^{\circ} \text { mês } \\
\text { (set-07) }\end{array}$}} & \multirow{2}{*}{\multicolumn{3}{|c|}{$\begin{array}{l}6^{\circ} \text { mês } \\
\text { (dez-07) }\end{array}$}} & \multirow{2}{*}{\multicolumn{3}{|c|}{$\begin{array}{l}11^{\circ} \text { mês } \\
\text { (mai-08) }\end{array}$}} \\
\hline & Intervenção & \begin{tabular}{|l} 
Potabilidade \\
\end{tabular} & Intervençäo- & "Tap Water" & & & & & & & & & & & & & & \\
\hline $\begin{array}{l}\text { Ferro Dissolvido } \\
\end{array}$ & $\begin{array}{c}0,3 \\
\end{array}$ & 0,3 & & $1,10 \mathrm{E}+01$ & 0,572 & 0,009 & 0,079 & 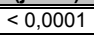 & $2<0,0001$ & NA & NA & NA & NA & NA & NA & 13,5 & NA & $\begin{array}{l}<0.0001 \\
\end{array}$ \\
\hline Sulfato & 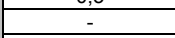 & 250 & - & & $<1$ & $<1$ & 198 & $<1$ & $<1$ & NA & $\mathrm{NA}$ & NA & 92,1 & NA & 3,9 & 12,8 & NA & $<1$ \\
\hline Alcalinidade Total & - & - & - & - & 62 & $<5$ & 132 & $<5$ & $<5$ & NA & NA & NA & 49 & NA & $<5$ & $<5$ & NA & $<5$ \\
\hline RedEq & - & - & - & - & 4,8 & $<1$ & 120 & $<1$ & $<1$ & 3,4 & NA & 1,8 & 60 & 1,3 & 1,3 & $<1$ & $<1$ & $<1$ \\
\hline
\end{tabular}

Portaria n⿳ 51804: Padrăo de Potabilidade estabelecido pelo Miniteŕio da Saúde

CETESB: Companhia de Tecnologia de Saneamento Ambiental

D.R.F.: Dutch Reference Framework

PRGs: Preliminary Remediation Goals (Region IX)

-: Năo estabelecido
NA: năo analisado 